\title{
Late blight: pathogen variability and disease resistance breeding in Ecuador
}

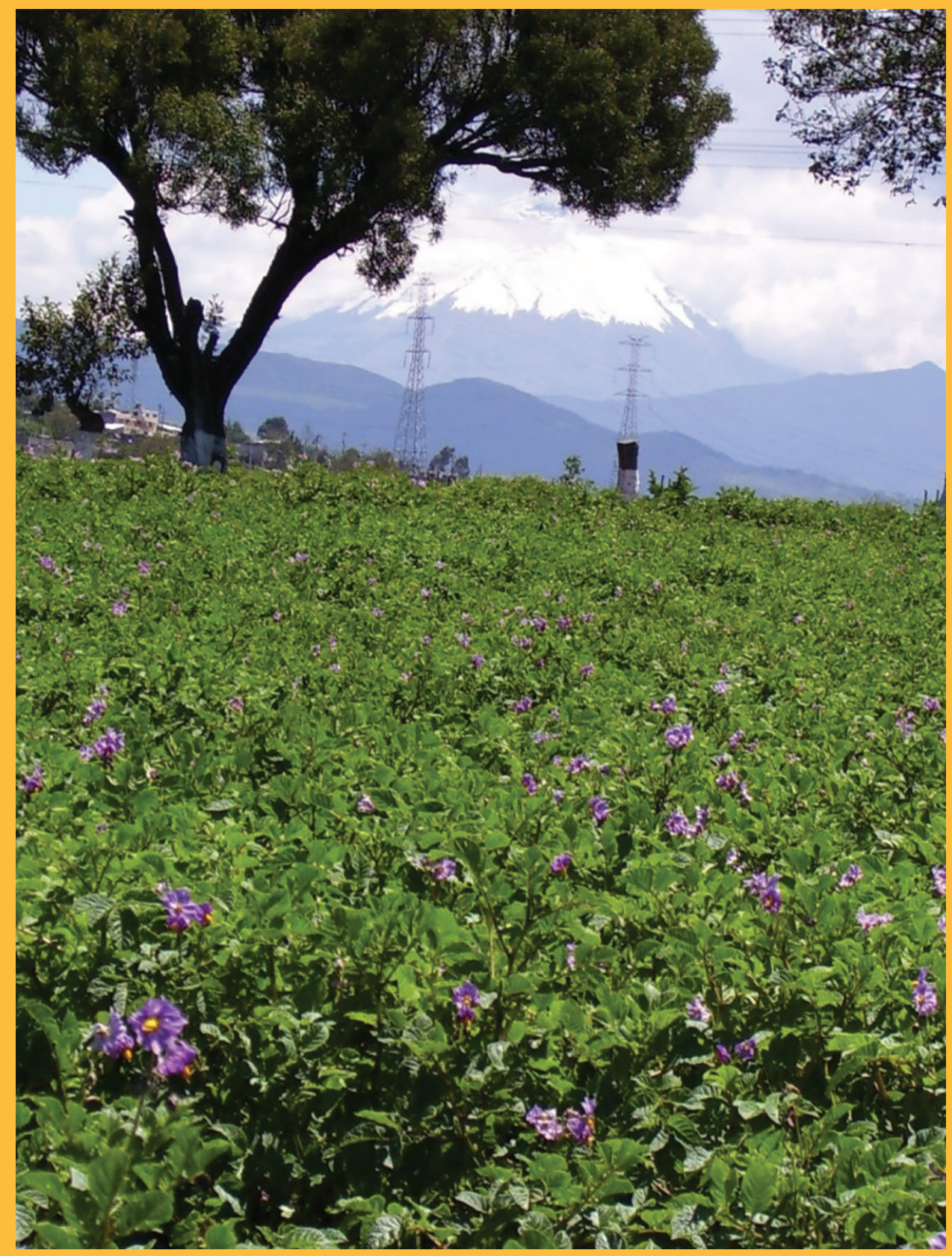

\section{Ricardo Delgado}




\section{Late blight: pathogen variability and disease resistance breeding in Ecuador}




\section{Thesis committee}

\section{Promotor}

Prof. Dr. Richard G.F. Visser

Professor of Plant Breeding

Wageningen University \& Research

\section{Other members}

Prof. Dr. Titti Mariani, Radboud University Nijmegen

Prof. Dr. Paul Struik, Wageningen University \& Research

Prof. Dr. Anton Haverkort, Nigde University, Turkey

Dr. Conny Almekinders, Wageningen University \& Research

This research was conducted under the auspices of the Graduate School of Experimental Plant Sciences. 


\section{Late blight: pathogen variability and disease resistance breeding in Ecuador}

\section{Ricardo Delgado}

\section{Thesis}

submitted in fulfilment of the requirements for the degree of doctor at Wageningen University by the authority of the Rector Magnificus

Prof.Dr A. P. J. Mol, in the presence of the

Thesis Committee appointed by the Academic Board

to be defended in public

on Monday 21 October 2019

at 4 p.m. in the Aula. 
Ricardo Delgado

Late blight: pathogen variability and disease resistance breeding in Ecuador 136 pages

PhD thesis, Wageningen University, Wageningen, The Netherlands (2019) With references, with summaries in English and Spanish

ISBN: 978-94-6343-947-3

DOI: https://doi.org/10.18174/475569 


\section{Contents}

Chapter 1

Page

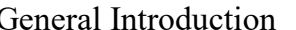

Chapter 2

Breeding for potato late blight resistance in Ecuador: INIAP's efforts $\square$

Chapter 3

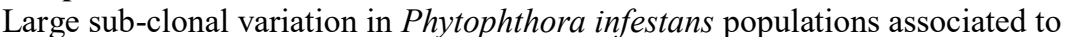

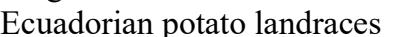

Chapter 4

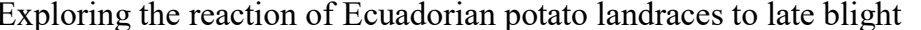

\section{Chapter 5}

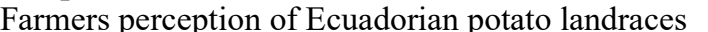

Chapter 6

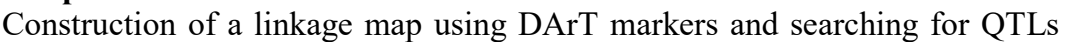

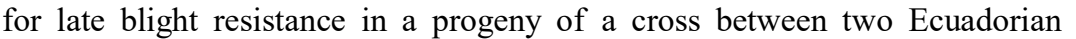

$\square\|\|\|\|\|\|\|\|\|\|$

\section{Chapter 7}

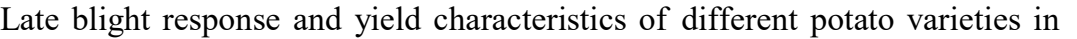

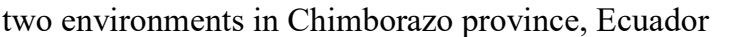

\section{Chapter 8}

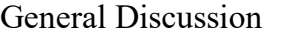

Summary

\section{Resumen}

\section{Acknowledgements}

About the author

List of publications

Education Statement 
Dedication

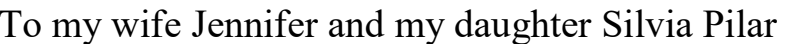

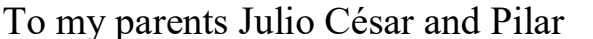




\section{CHAPTER 1}

\section{General Introduction}

$\square$

\section{Potato crop}

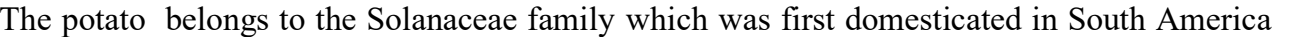

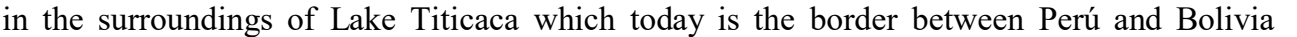

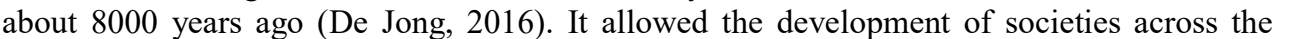

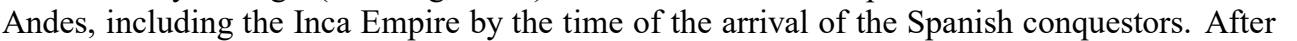

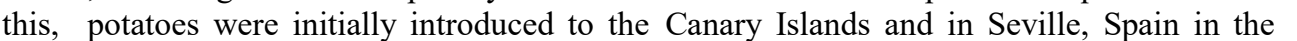

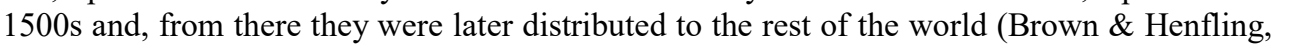

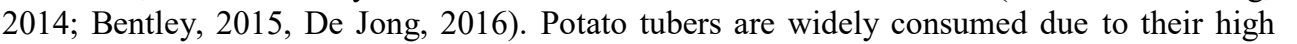

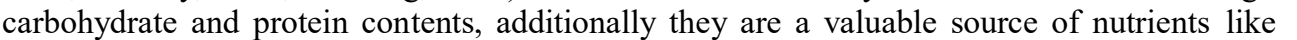

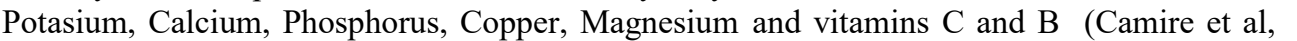

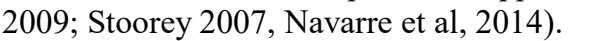

$\square$

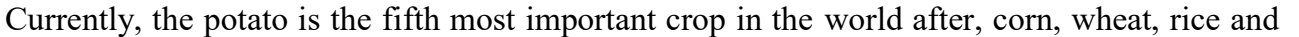

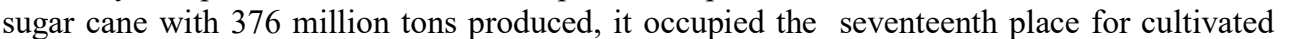

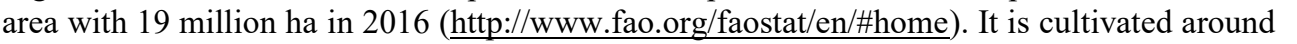

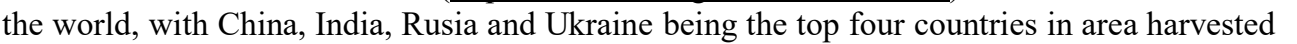

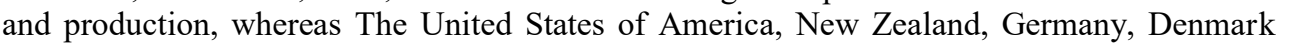

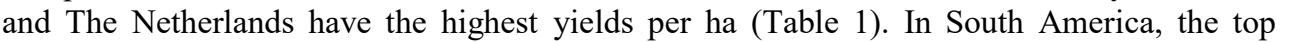

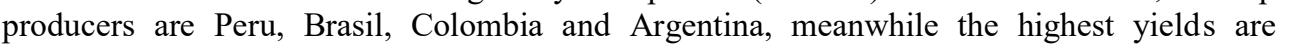

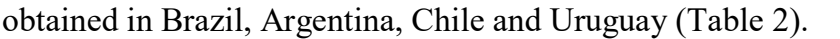

$\square$

\section{Potato in Ecuador}

$\square$

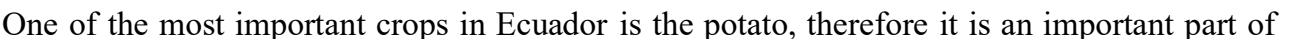

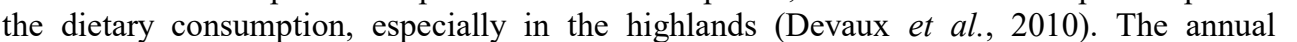

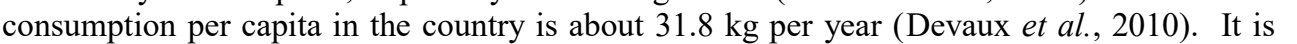

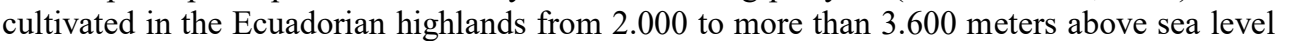

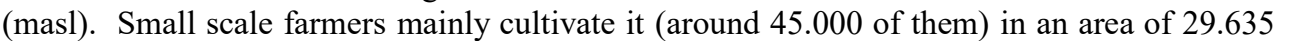

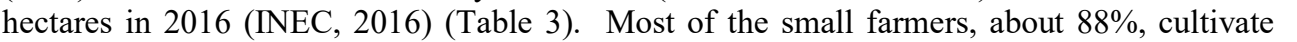

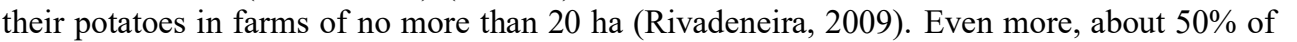

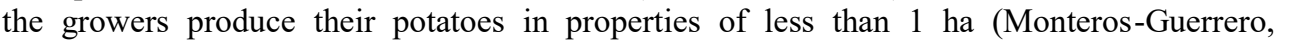

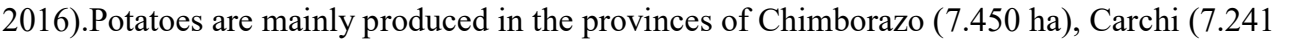

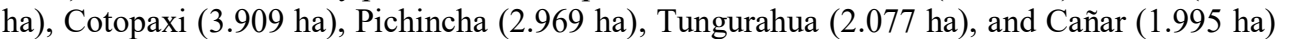

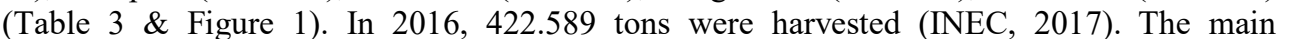

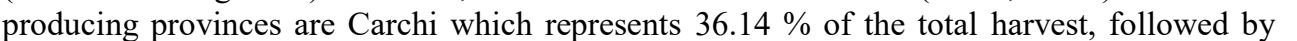

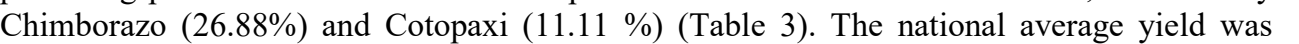

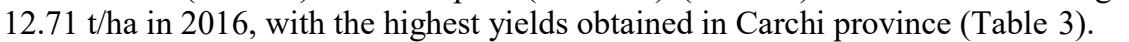

$\square$ 


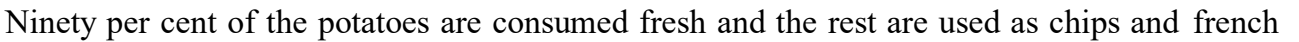

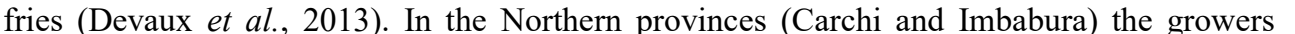

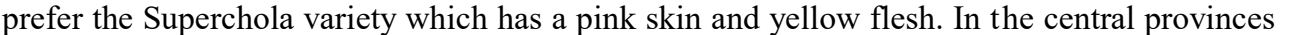

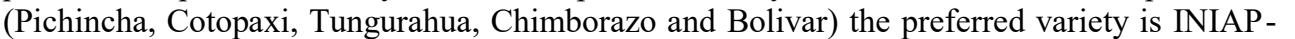

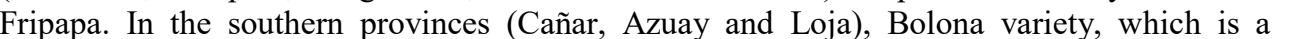

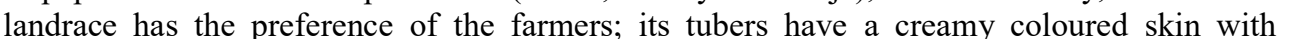

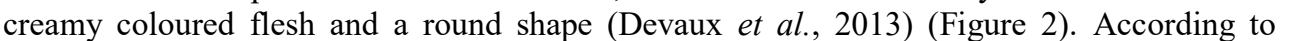

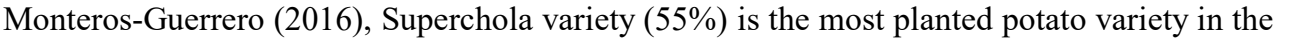

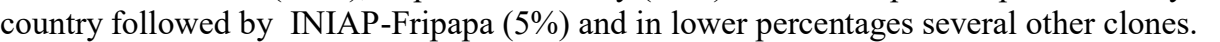

$\square$

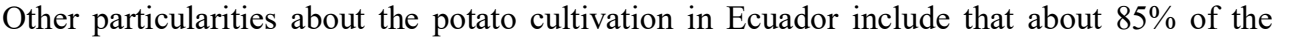

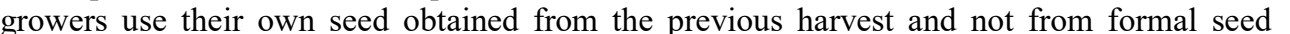

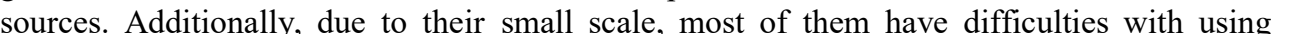
ए ए।

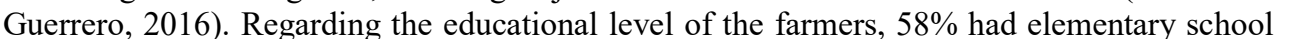

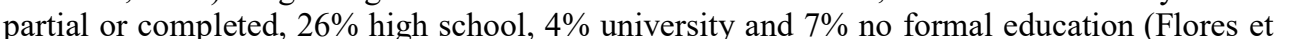

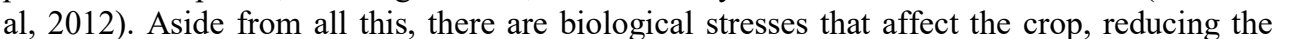

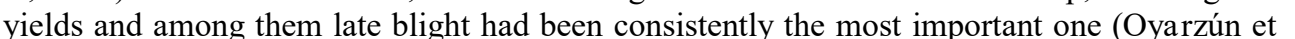

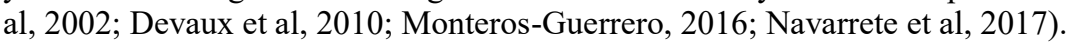

$\square$

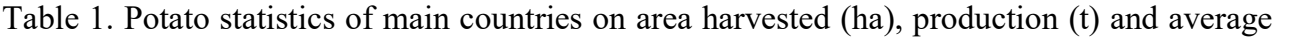

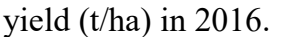

\begin{tabular}{|c|c|c|c|c|c|}
\hline 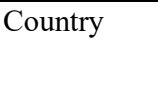 & $\begin{array}{l}\square \square \| \square \\
\square\|\|\|\| \square \\
\square\|\| \square\end{array}$ & 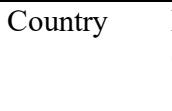 & 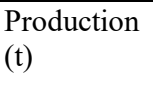 & 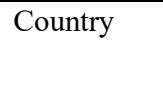 & 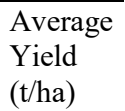 \\
\hline 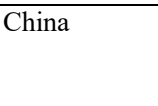 & $\square\|\|\|\|$ & 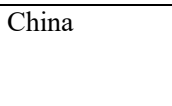 & $\square\|\|\|\|$ & 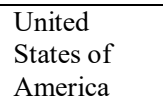 & $\square$ \\
\hline पाणाए & $\square\|\| \square$ & पण口卄 & $\square\|\| \|$ & $\begin{array}{l}\square \square \square \\
\square \square \| ा \square\end{array}$ & $\square ा$ \\
\hline$\square \square \mathbb{M}$ & $\square\|\| \Pi$ & $\square \square \| \square$ & $\square\|\| \|$ & - $\square \square \square \square ा प$ & पाप \\
\hline पणणाण & $\square\|\| \amalg$ & पमणाण & $\square\|\| \|$ & $\square \square \square \square \square$ & पाण \\
\hline पमाणायप & $\square \prod \Pi$ & 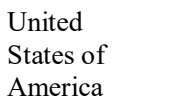 & $\square\|\| \|$ & $\square \square\|\|\|\|\|\|$ & 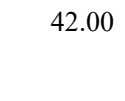 \\
\hline 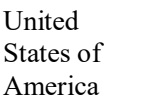 & $\square \prod \|$ & पणापा & $\square\|\Pi\|$ & - & $\square \square$ \\
\hline पमाप & 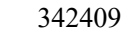 & 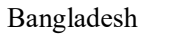 & $\square\|\| \|$ & 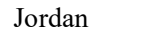 & $\square \square$ \\
\hline पएणाण & $\square \| \Pi$ & $\square \square|ल| \square$ & $\square\|\| \|$ & पाणाणा & पाए। \\
\hline 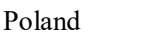 & $\square \Pi \| \amalg$ & 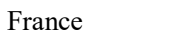 & $\square\|\| \|$ & 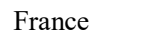 & $\square \square$ \\
\hline$\square \square \square \square$ & $\square \Pi \Pi \square$ & 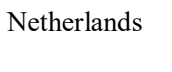 & $\square\|\Pi\|$ & $\begin{array}{l}-\square \square\|\| \square \\
\square \square\|\| \square \square\end{array}$ & $\square ा I$ \\
\hline 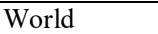 & 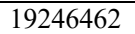 & 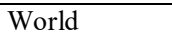 & 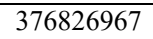 & $-\square \square \|$ & $\square \square$ \\
\hline
\end{tabular}

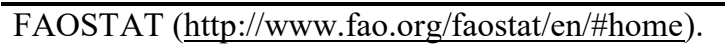

$\square$ 


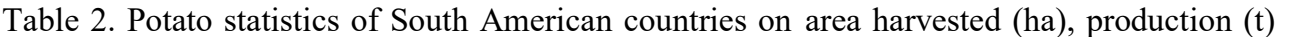

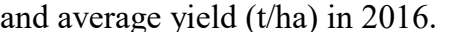

\begin{tabular}{|c|c|c|c|}
\hline & 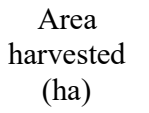 & 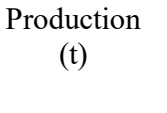 & 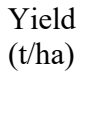 \\
\hline पा। & & +1 & 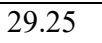 \\
\hline पणताण & पामा & $\square\|1\| \square$ & पाएा \\
\hline पणमाण & पएमा & पППए & $\square \square \square$ \\
\hline 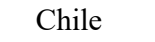 & पाПए & 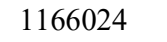 & 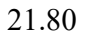 \\
\hline पएणपा & 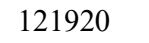 & $\square\|\Pi\| \square$ & पणम \\
\hline$\square \square \| 11 \mathbb{\square}$ & पाएम & $\square\|\| \square$ & पाण \\
\hline पषणामा & $\square \square$ & $\square \Pi \square$ & पाण \\
\hline$\square \square \square \square$ & $\square \| \Pi \square$ & $\square\|\| \|$ & पाण \\
\hline पायाय & $\square \prod \square$ & $\square 1$ & 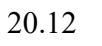 \\
\hline$\square 11$ & 1111 & 11 & \\
\hline
\end{tabular}

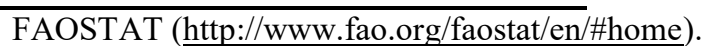

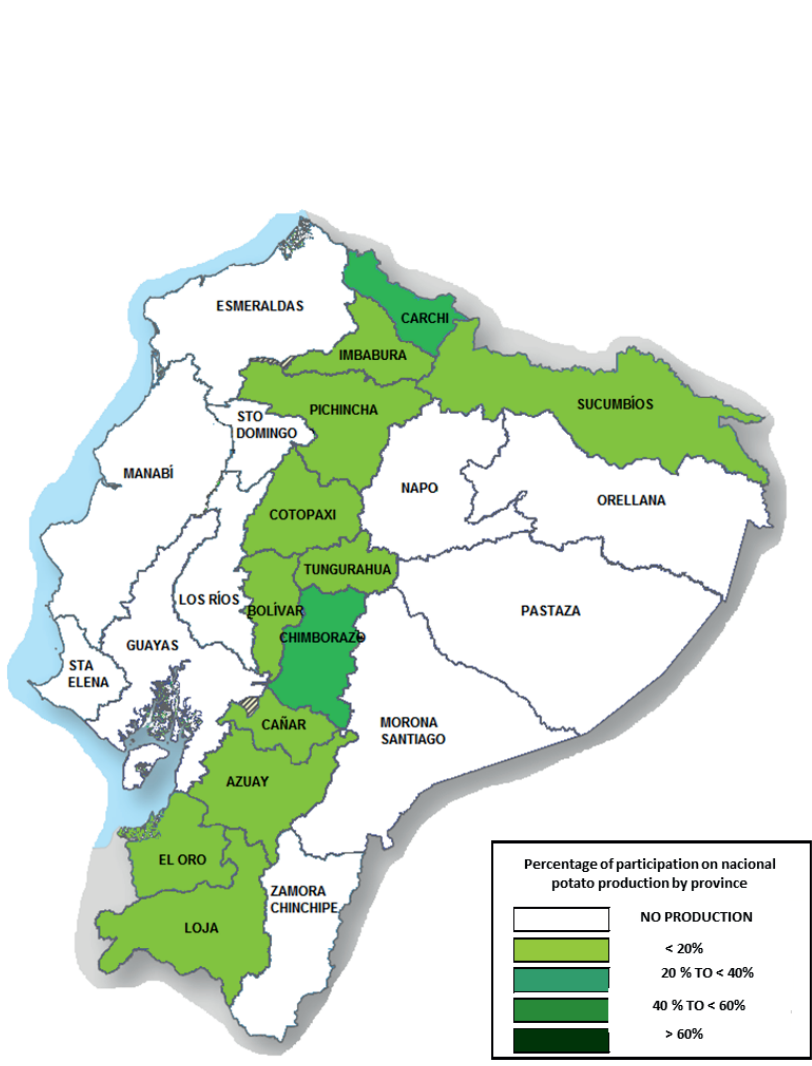

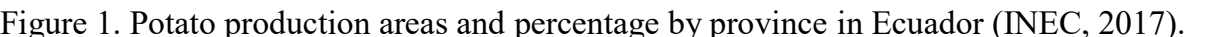




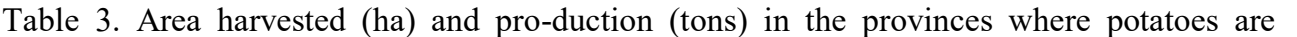

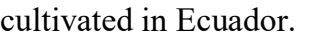

\begin{tabular}{|c|c|c|c|c|c|}
\hline पणापाए & 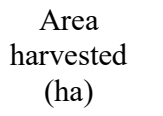 & $\begin{array}{c}\square \square \| \square \square \square \square \\
\square \square\end{array}$ & 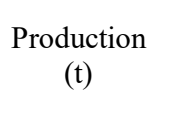 & $\begin{array}{c}\square \square\|\| \square \| \square \\
\square \square\end{array}$ & 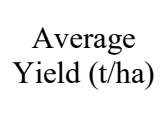 \\
\hline 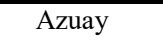 & 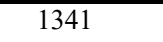 & 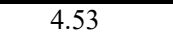 & $\overline{\square \square \square}$ & 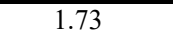 & 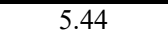 \\
\hline पवाणाप & 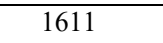 & 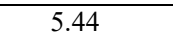 & $\square \| \Pi$ & पाण & 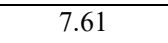 \\
\hline 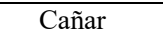 & 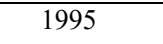 & 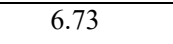 & $\square \square \square$ & 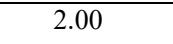 & 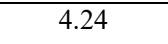 \\
\hline$\square \square\|\| \| \square$ & 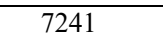 & 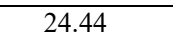 & $\square\|\| \| I$ & 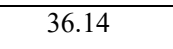 & $\square|\square| \square$ \\
\hline 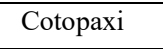 & 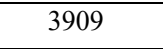 & \begin{tabular}{l|l|l|}
$\square|\square|$ \\
\end{tabular} & 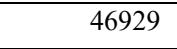 & \begin{tabular}{l|l|l|}
$\square|\Pi|$ \\
\end{tabular} & 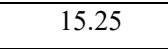 \\
\hline 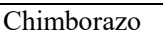 & 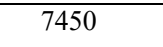 & $\begin{array}{l}\square \square \square \\
\end{array}$ & 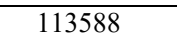 & $\square|\square| \square$ & $\square|\square| \square$ \\
\hline 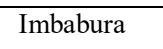 & $\square \square \square$ & 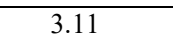 & $\square \square \square$ & 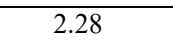 & $\square|\square| \square$ \\
\hline 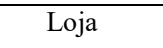 & $\square \square$ & 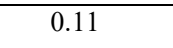 & $\square \square$ & 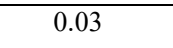 & पापाप \\
\hline पालापाएम & 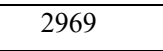 & 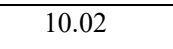 & 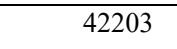 & 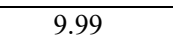 & पापाप \\
\hline 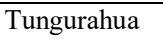 & 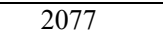 & 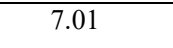 & $\square \square \square \square$ & 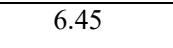 & 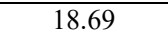 \\
\hline पण口冋 & $\square \square$ & 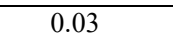 & $\square$ & 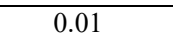 & $\square \square \square$ \\
\hline 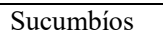 & $\square \square$ & 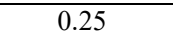 & $\square \square \square$ & 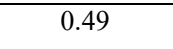 & \begin{tabular}{l|l|l|}
$\square \mid \Pi 1$ \\
\end{tabular} \\
\hline $\begin{array}{l}\square \square \square \\
\end{array}$ & 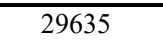 & $\square \square \square$ & $\square\|\| \|$ & $\square \square \square$ & $\square$ \\
\hline 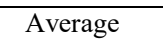 & 四 & $\square$ & 四 & $\mathbb{\square}$ & $\square|\square|$ \\
\hline
\end{tabular}

$\square$

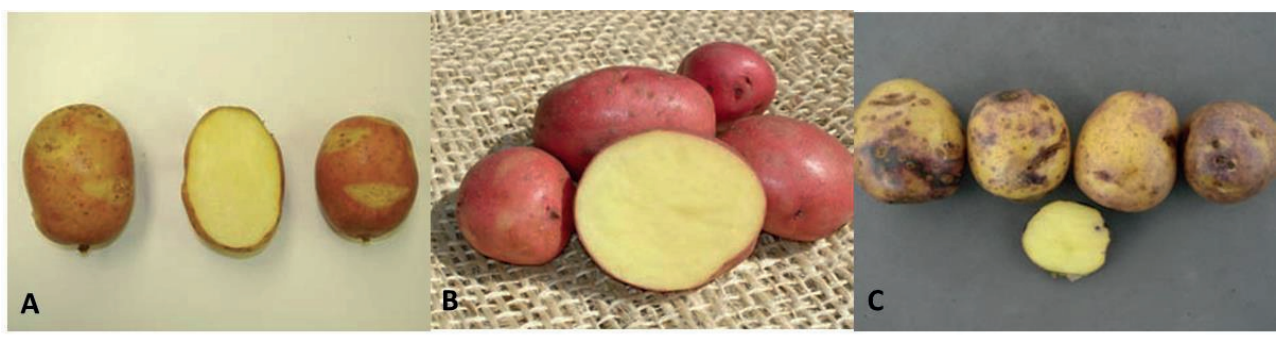

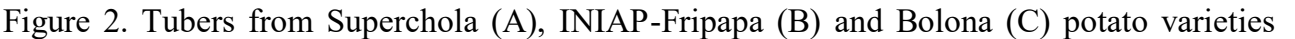

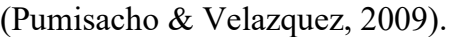

$\square$

\section{Late Blight around the world and in Ecuador}

$\square$

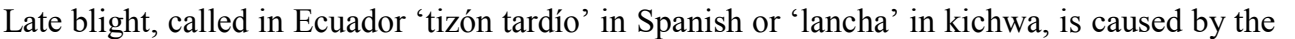

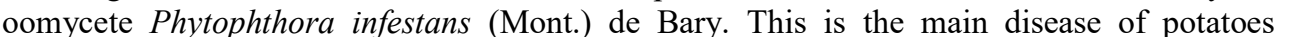

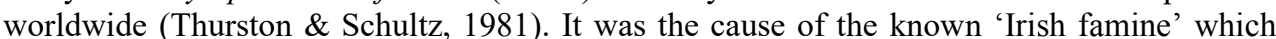

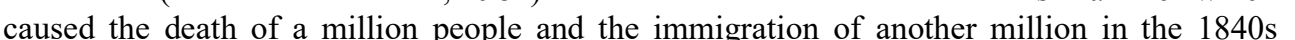

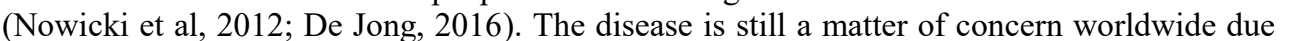




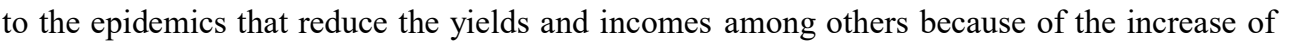
ए

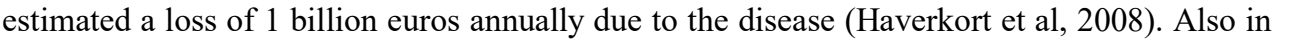

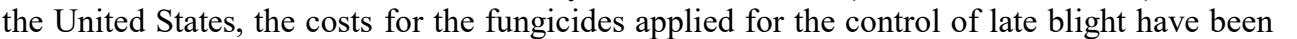

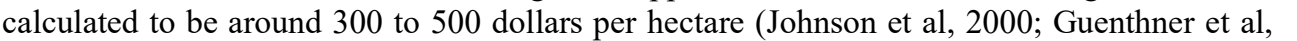
$\square \mid \Pi \|$

$\square$

प

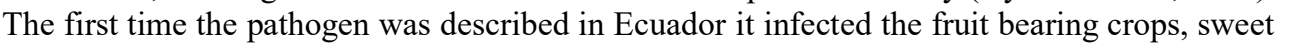

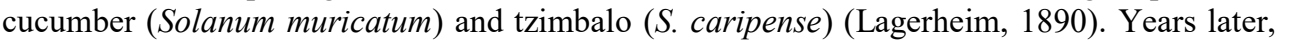

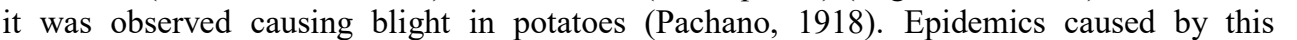

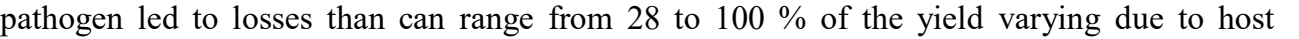

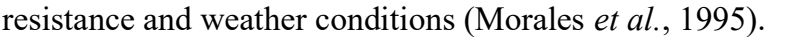

$\square$

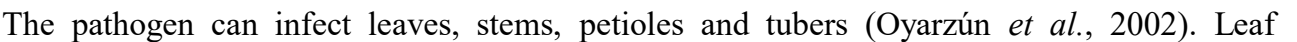

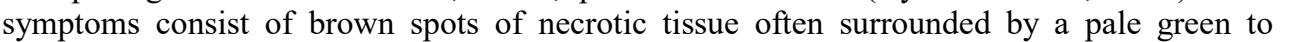

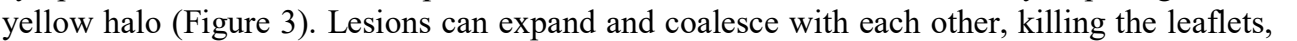

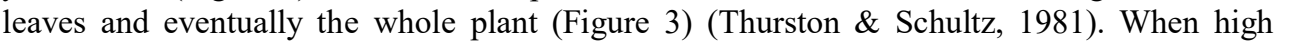

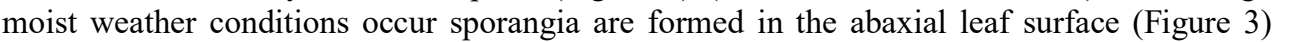

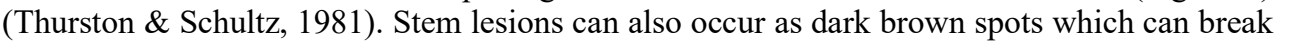

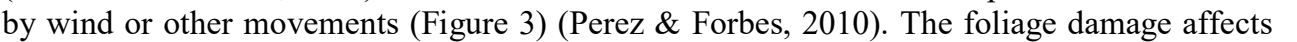

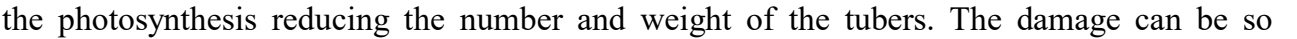

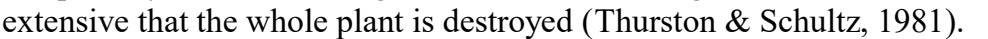

$\square$

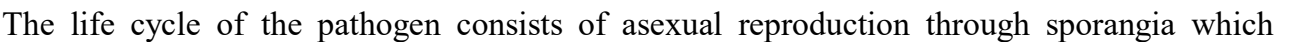

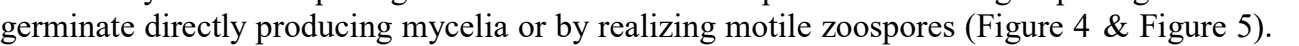

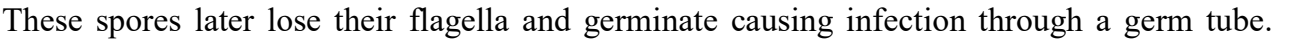

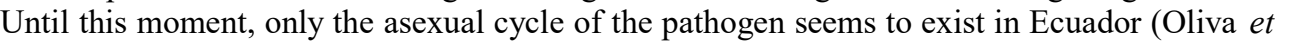

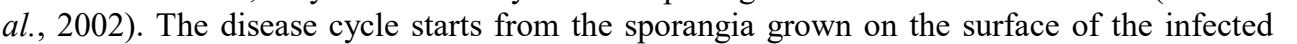

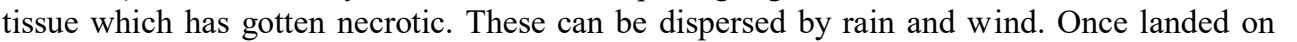

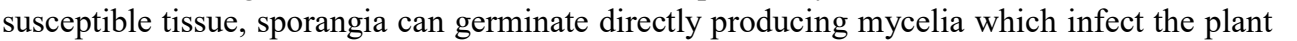

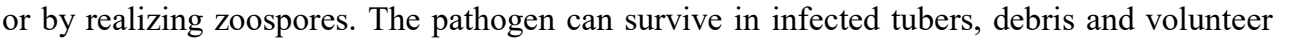

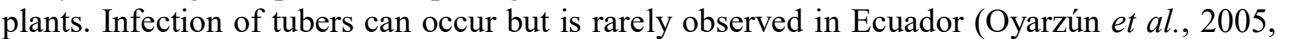

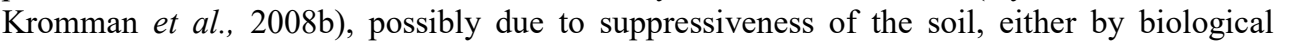

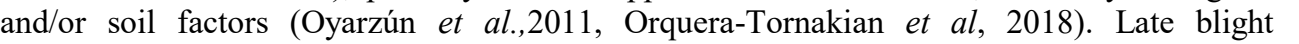

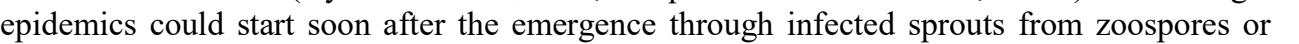

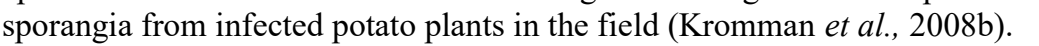

$\square$

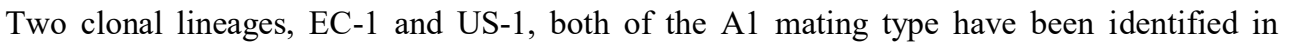

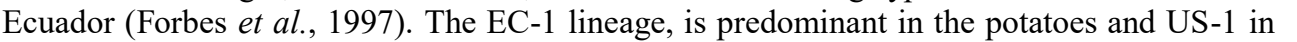

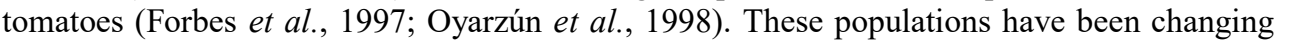
ए

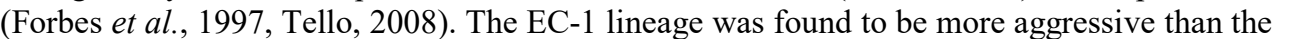

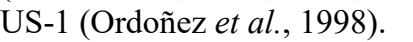




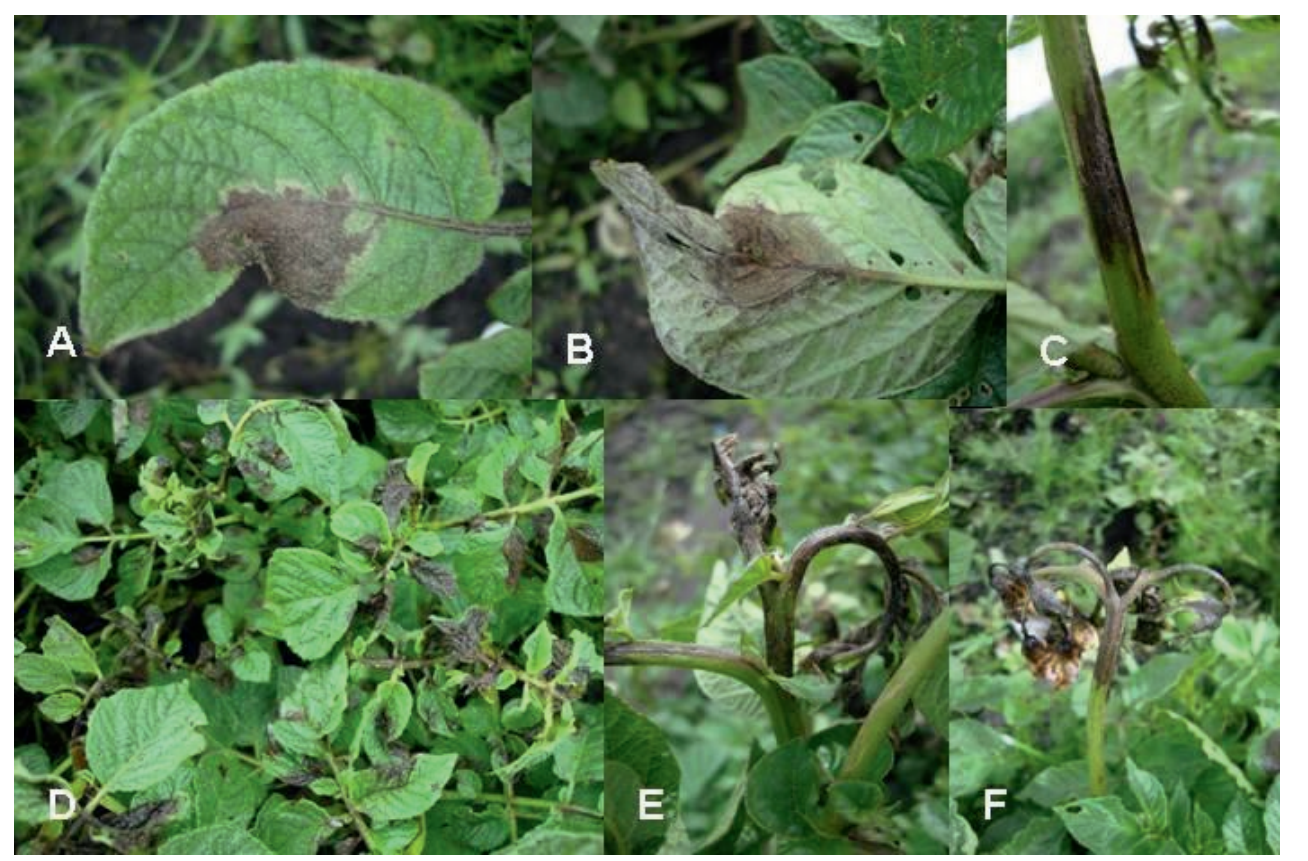

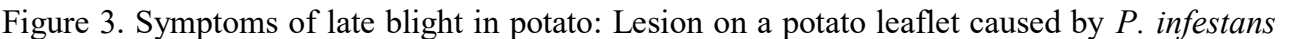

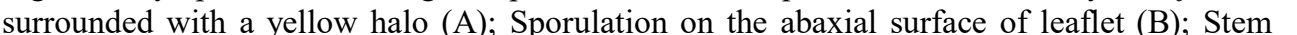

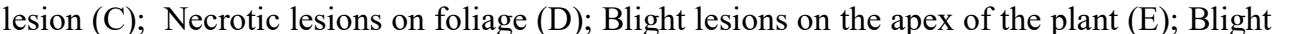

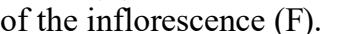

$\square$

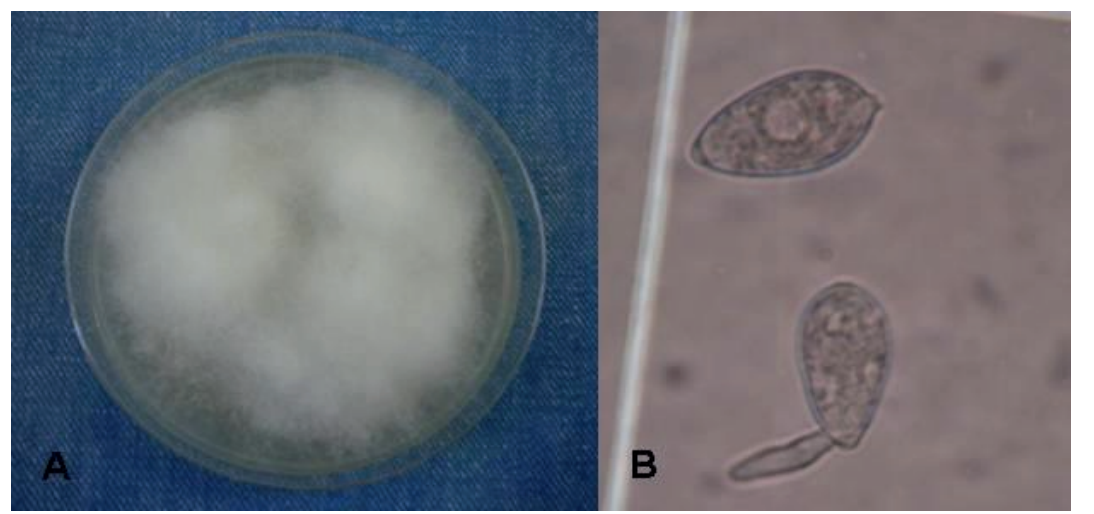

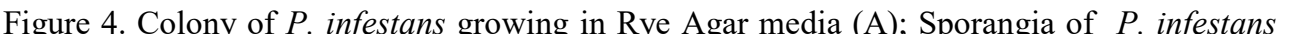
प⿴囗十丁口卄 


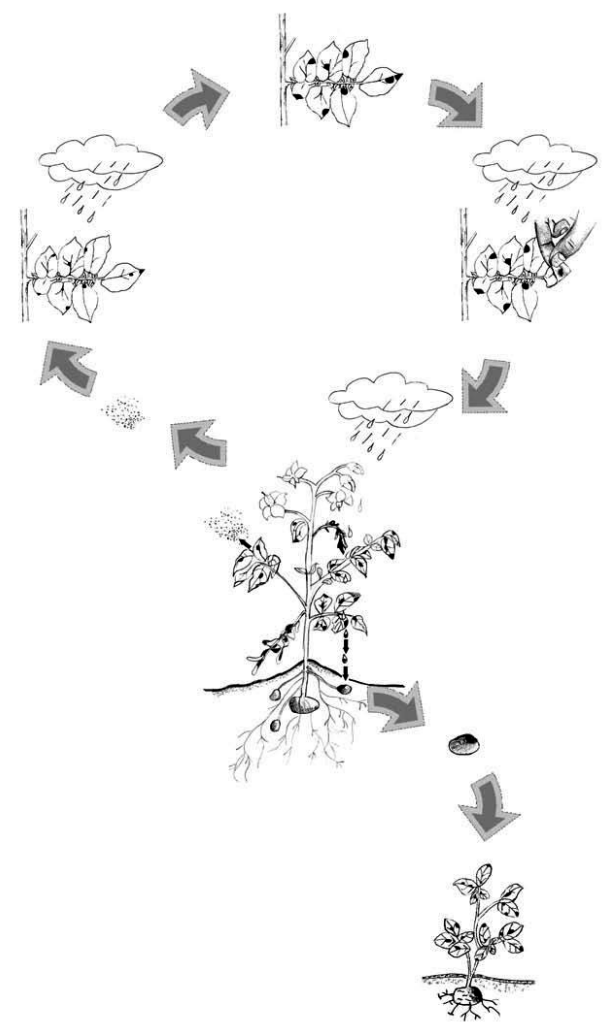

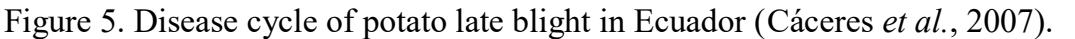

$\square$

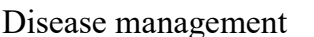

$\square$

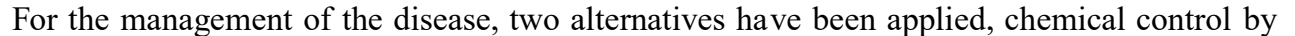

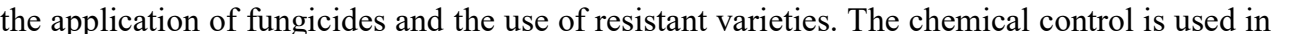

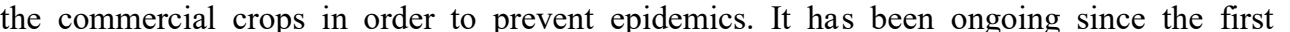

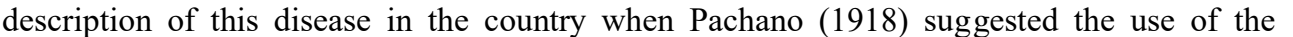

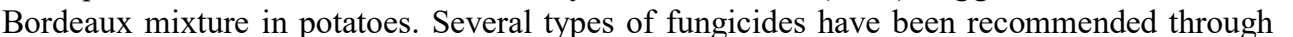

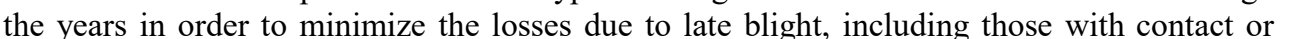

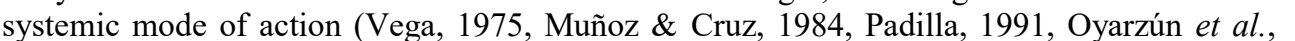

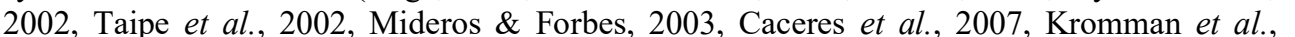

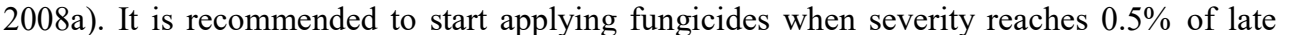

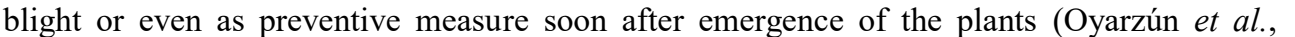

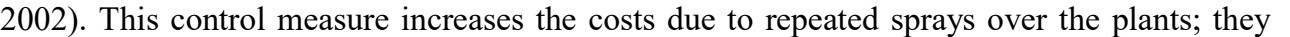

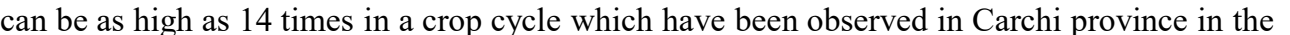

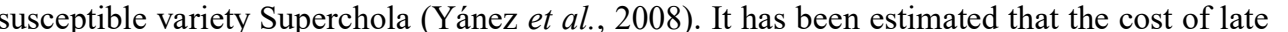

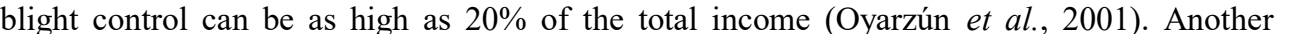

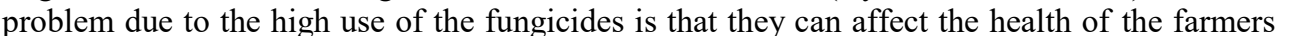




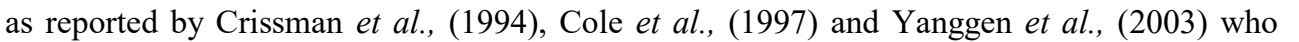

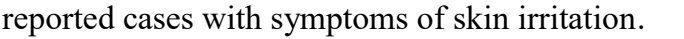

\section{$\square$}

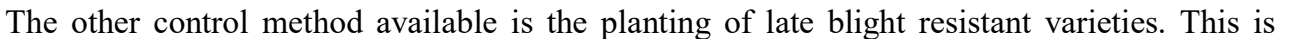
ए।

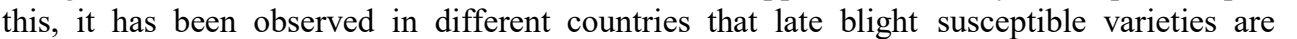

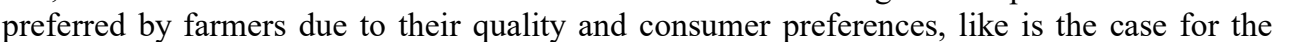

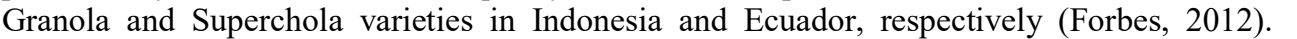

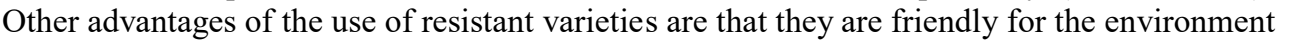

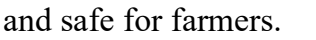

$\square$

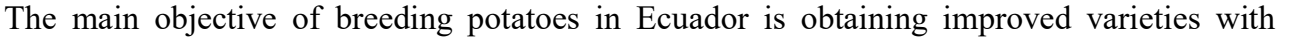

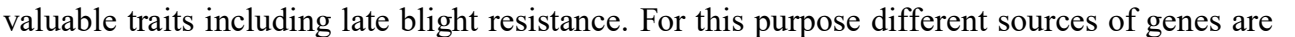

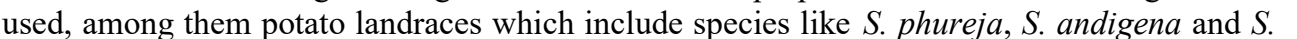

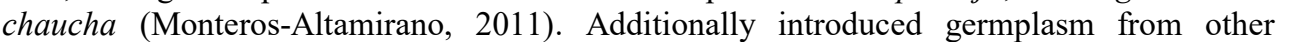

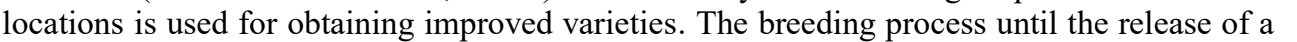

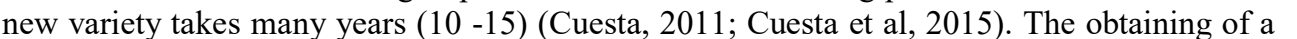

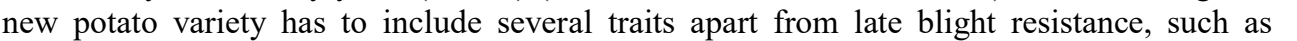

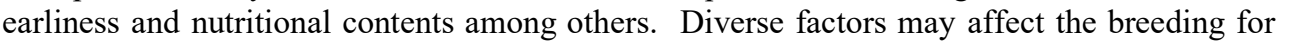
प

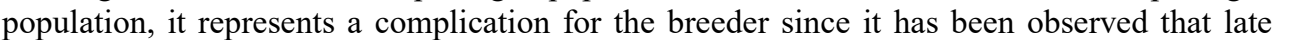

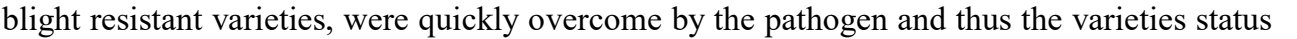

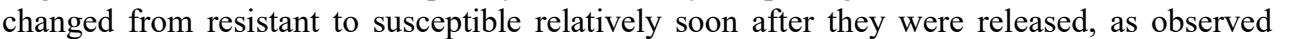

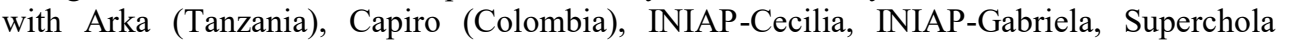

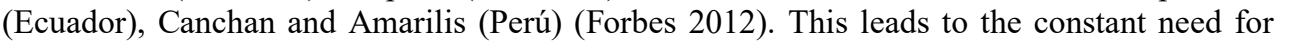

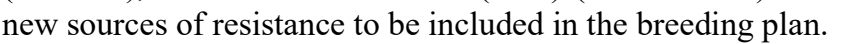

$\square$

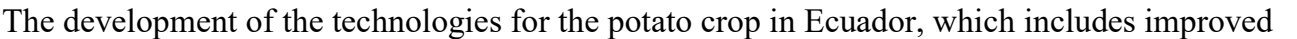

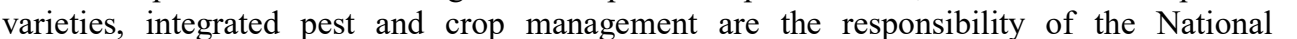

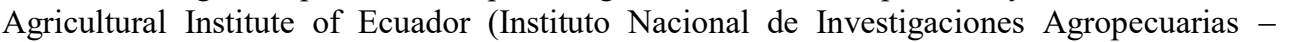

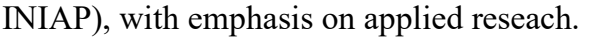

$\square$

\section{Scope of this thesis}

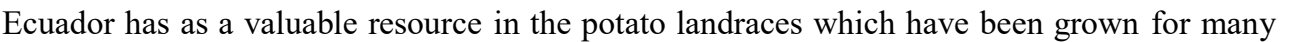

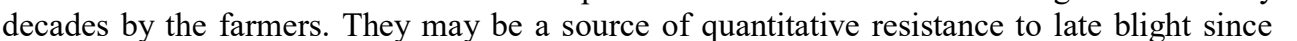

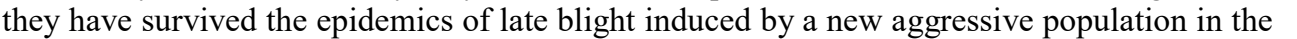

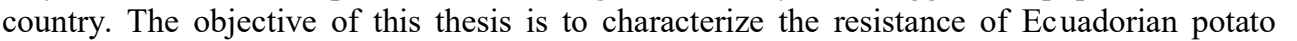

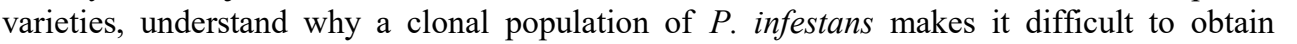

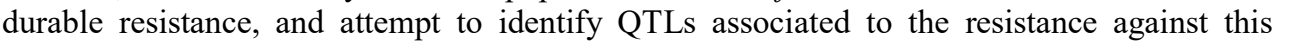

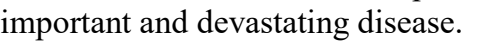




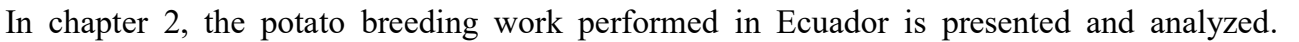

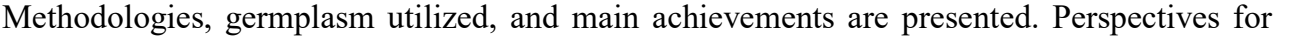

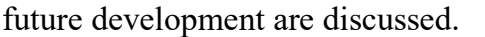

\section{$\square$}

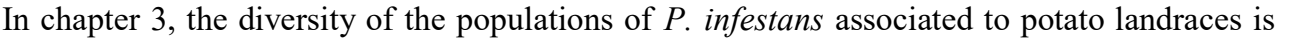

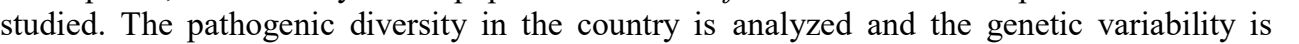

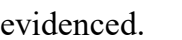

$\square$

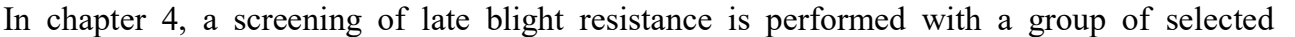

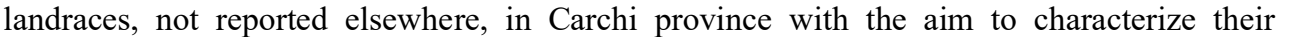

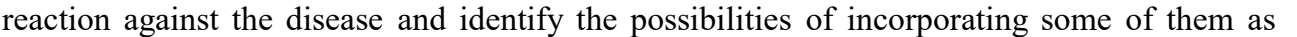

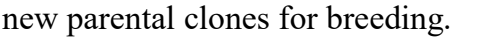

\section{$\square$}

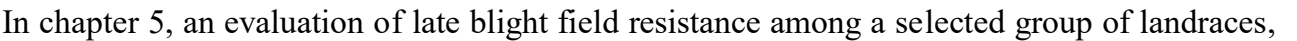

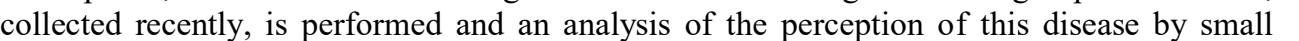

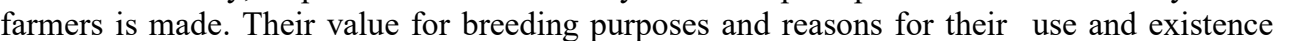

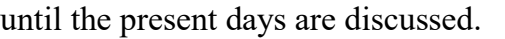

$\square$

प

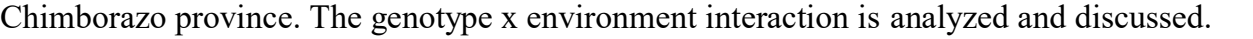

\section{$\square$}

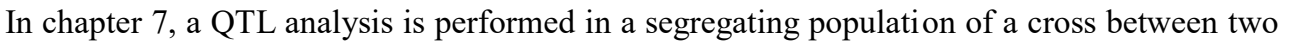

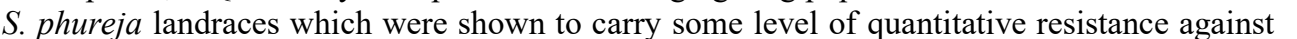

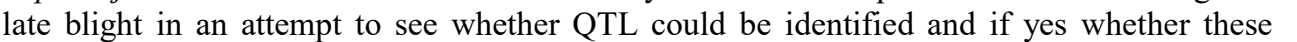

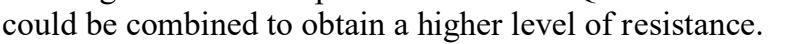

$\square$

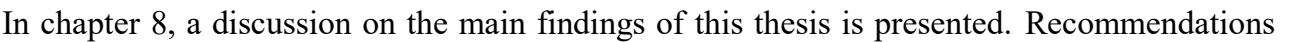

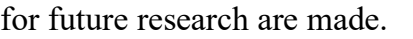

\section{Literature cited}

$\square$

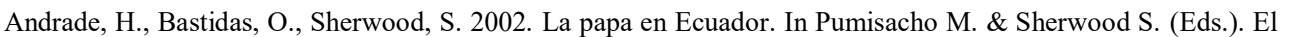

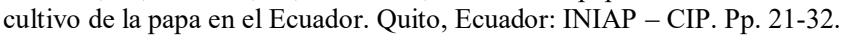
$\square$

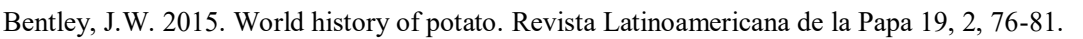
$\square$

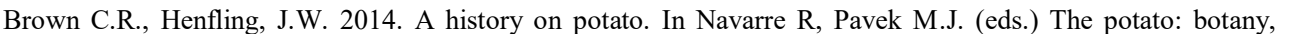

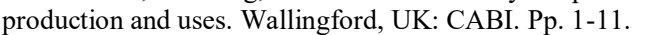

$\square$

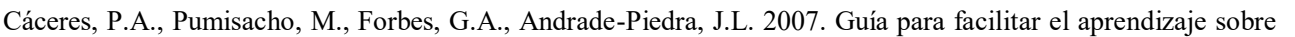

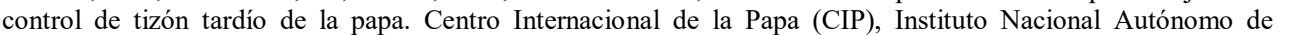




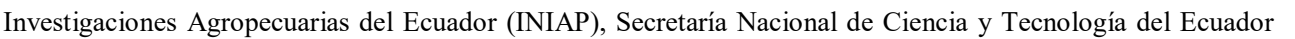

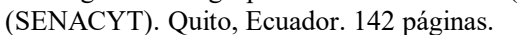

$\square$

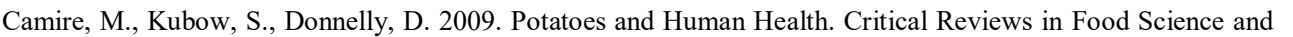

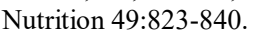

$\square$

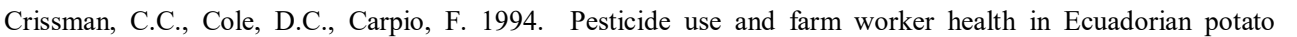

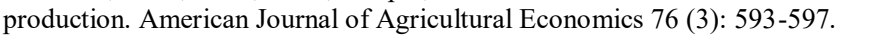

$\square$

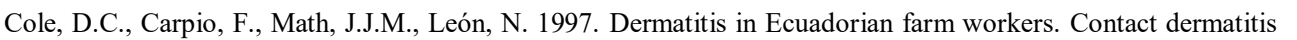
पाणाणाए

$\square$

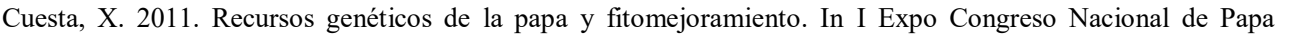

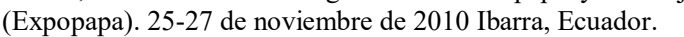

$\square$

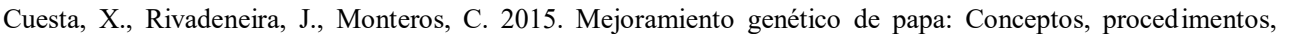

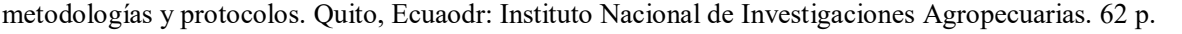
$\square$

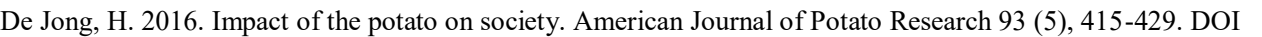

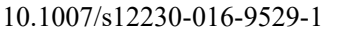

$\square$

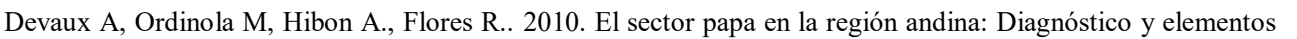
एण $\square$

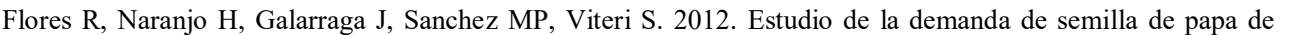

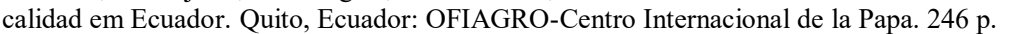

$\square$

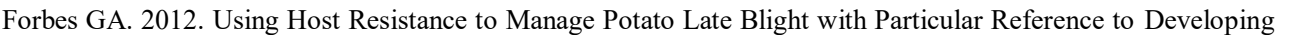

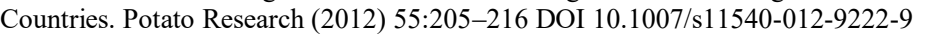
$\square$

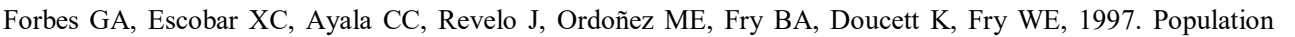

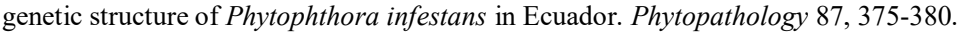
$\square$

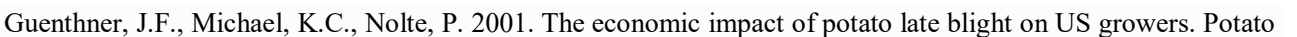

$\square \square$ earch $\square|\omega|$ https://doi.org/10.1007/BF02410098

$\square$

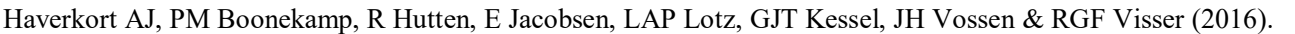

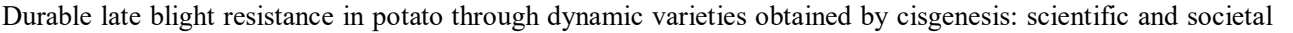

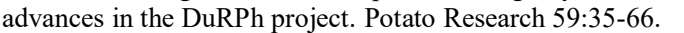
$\square$

प्र

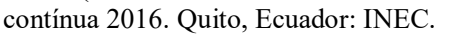
$\square$

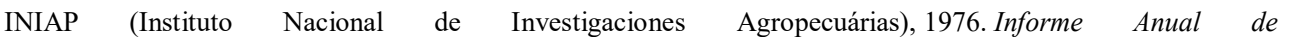

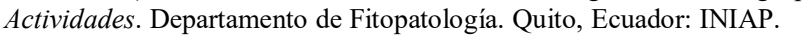
$\square$

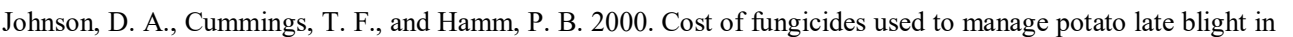

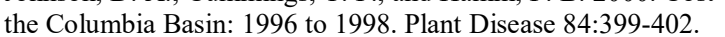
$\square$

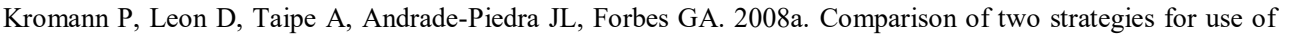

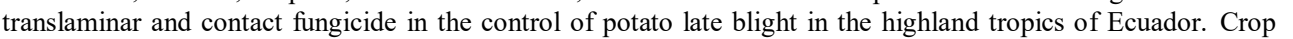

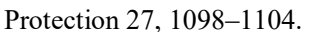

$\square$

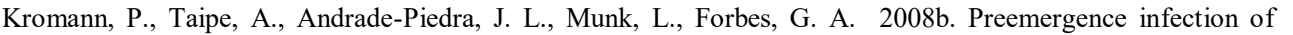

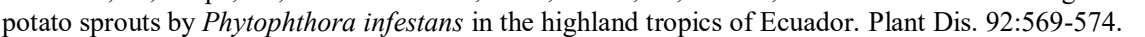
$\square$

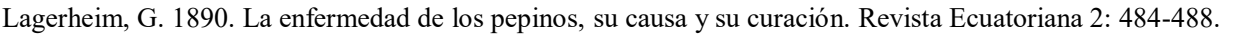

$\square \quad \square$

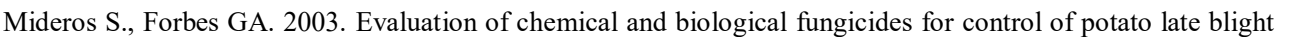

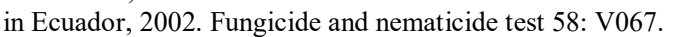


$\square$

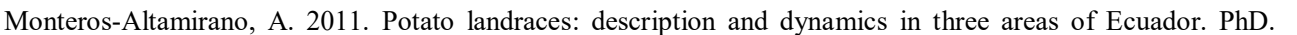

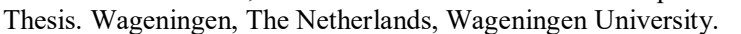

$\square$

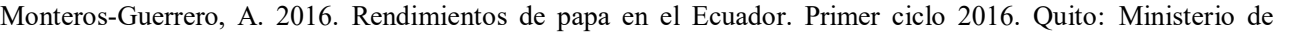

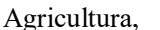
पालापणा
$\square$
प्णाणाए
$\square$
पाI

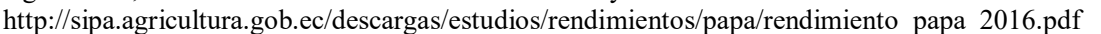

$\square$

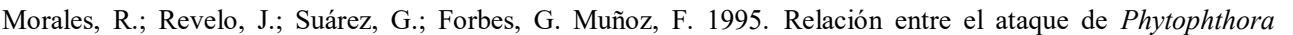

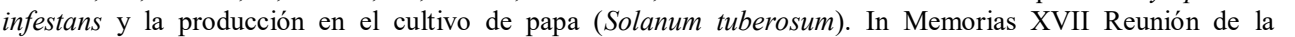

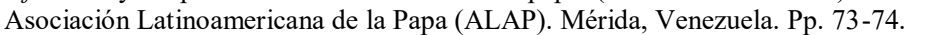

$\square$

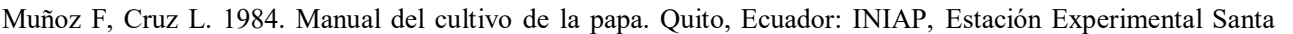
प्णाणाएा

$\square$

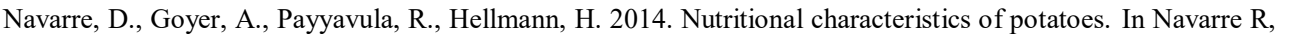

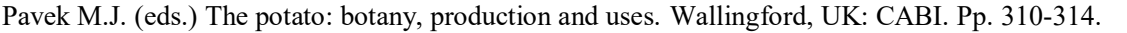
$\square$

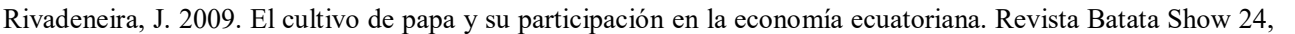
पाणाणा

$\square$

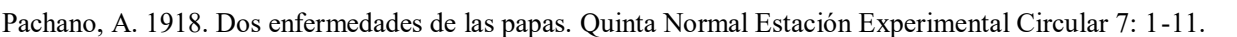
$\square$

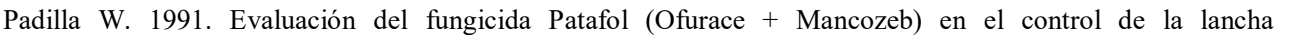

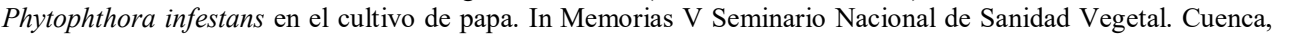

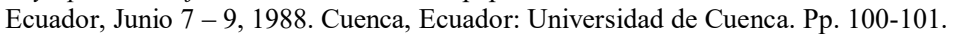

$\square$

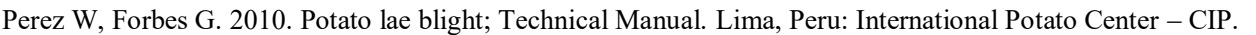
$\square$

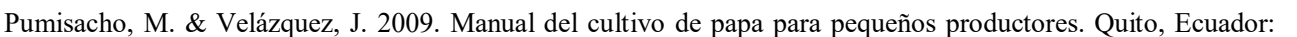

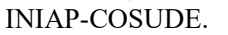

$\square$

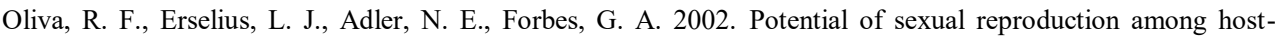

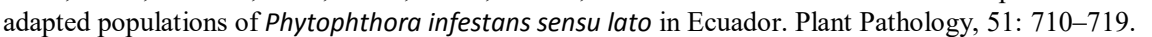
$\square$

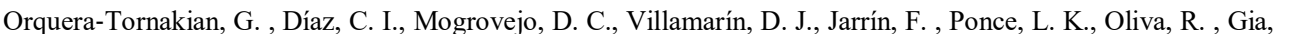
ए

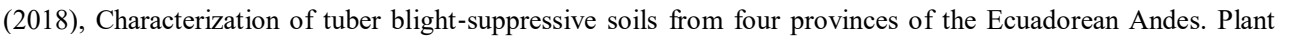

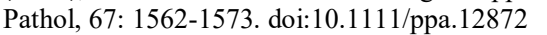

$\square$

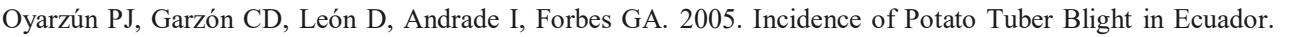

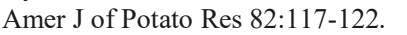

$\square$

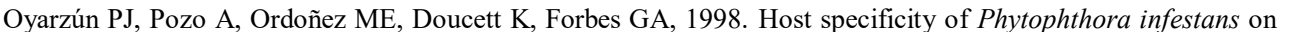

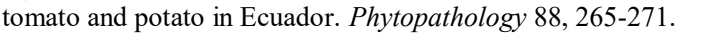
$\square$

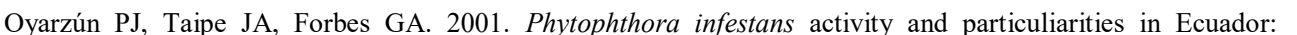

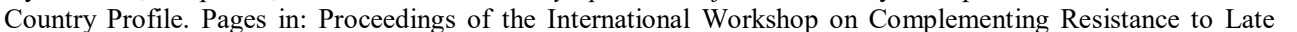

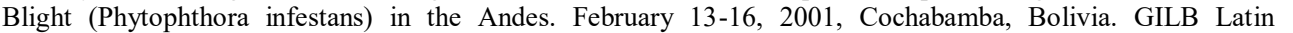

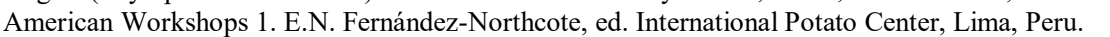
$\square$

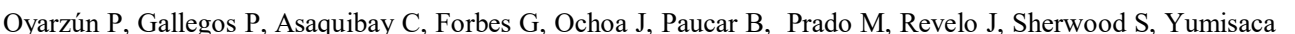

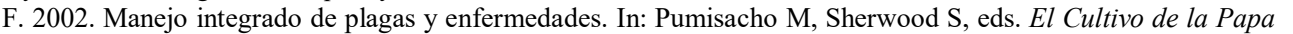

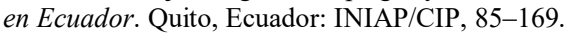
$\square$

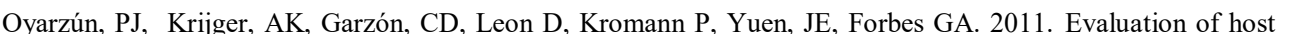

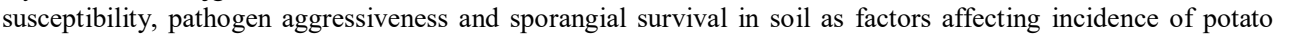

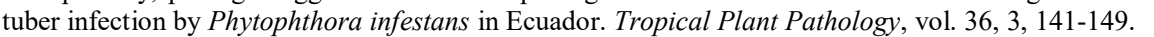
$\square$ 


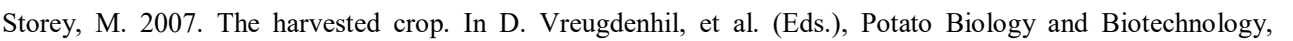

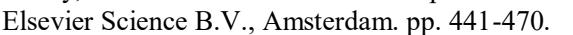

$\square$

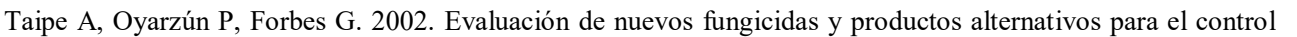

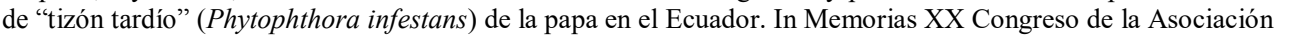

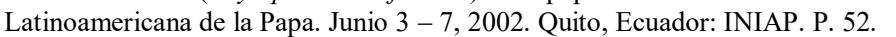

$\square$

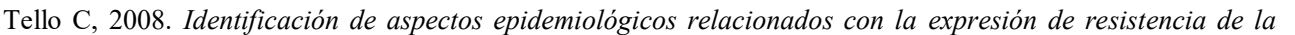

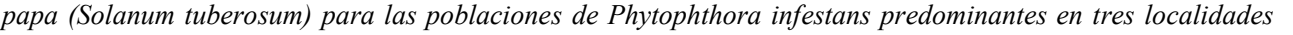

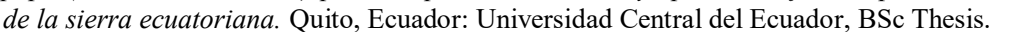

$\square$

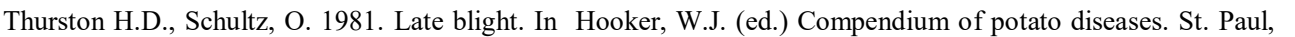

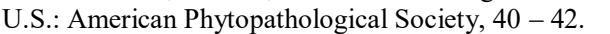

$\square$

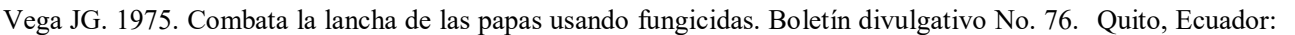

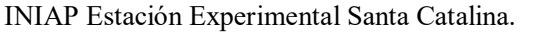

$\square$

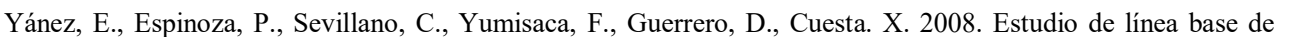

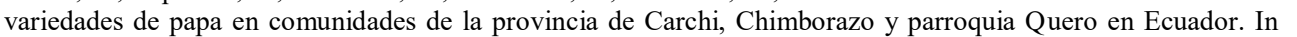

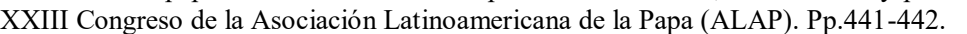

$\square$

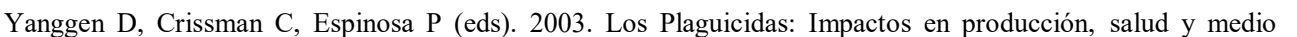

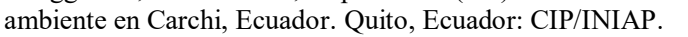




\title{
Chapter 2
}

\section{Breeding for potato late blight resistance in Ecuador: The National Agricultural Research Institute's INIAP's efforts}

\section{$\square$}

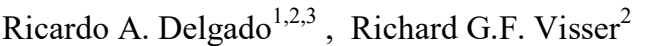

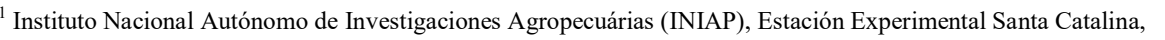

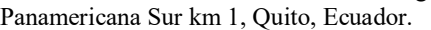

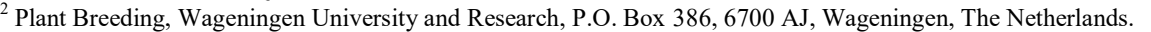

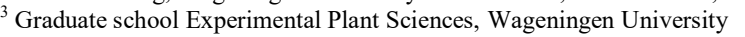

\begin{abstract}

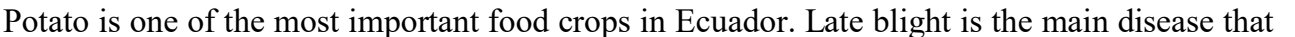

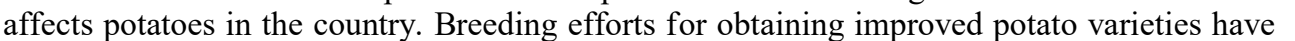

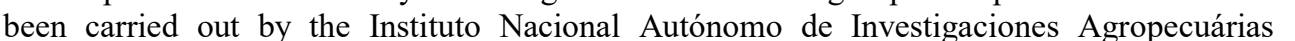

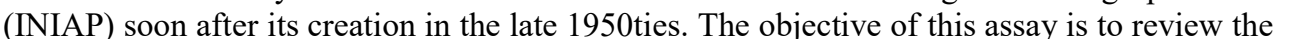

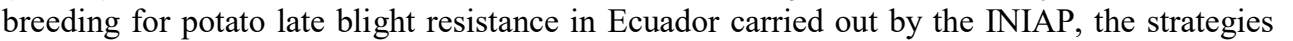

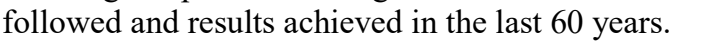

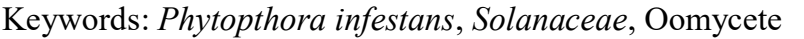

\section{Introduction}

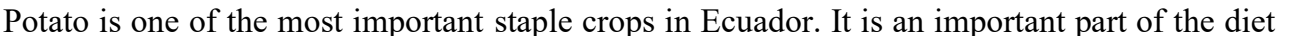

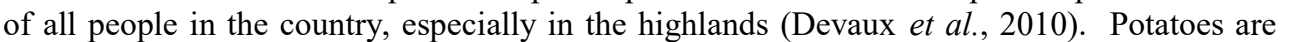

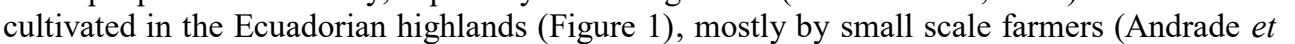

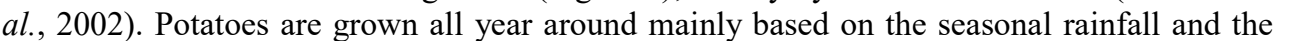

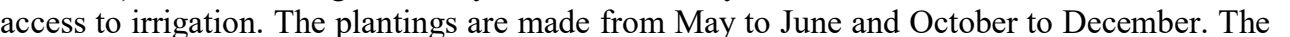

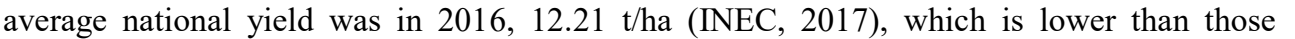

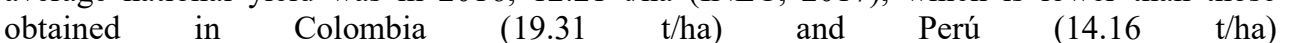

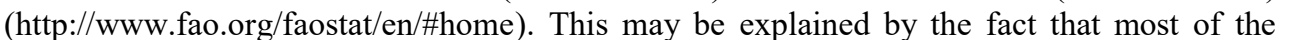

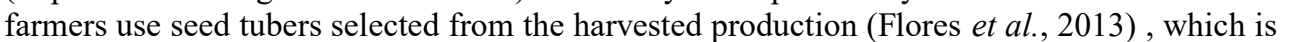

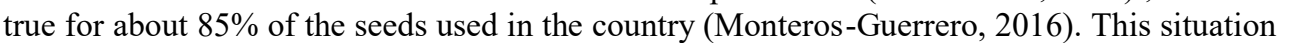

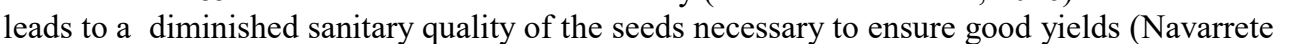

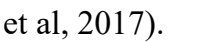




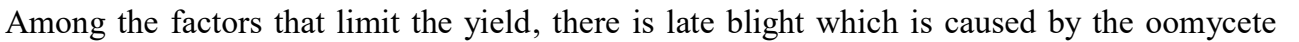

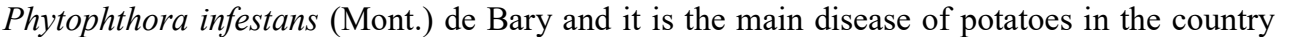

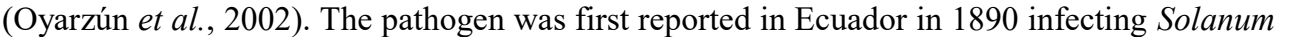

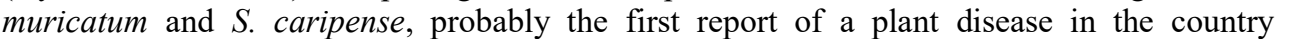

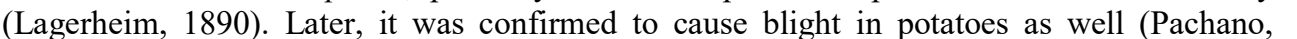

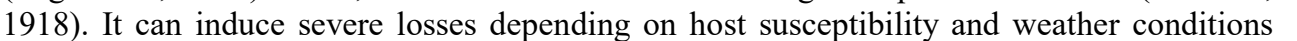

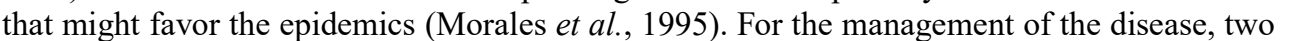

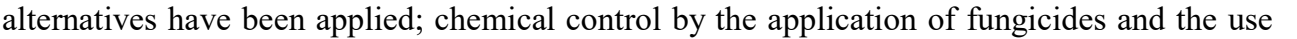

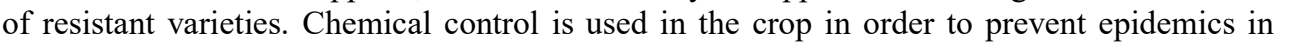

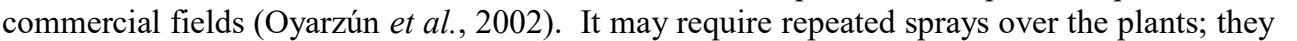

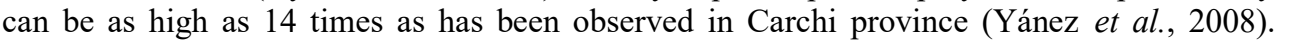

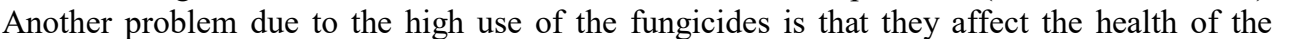

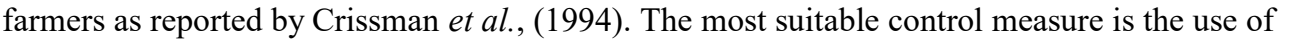

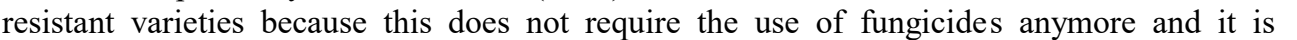

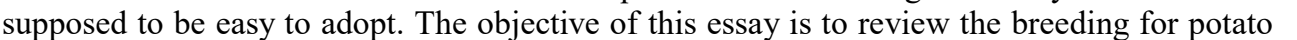

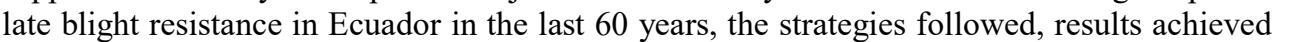

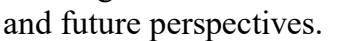

$\square$

\section{Potato Breeding in Ecuador}

$\square$

The breeding efforts in the country, started in Ambato in the 1910's with the trials set by the

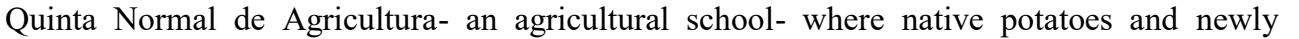

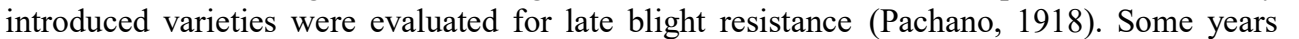

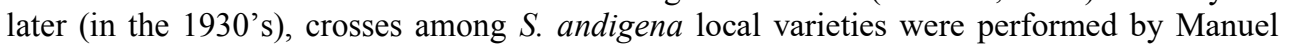

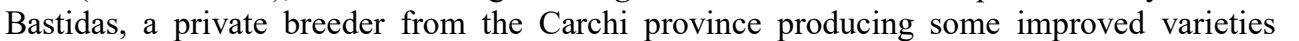

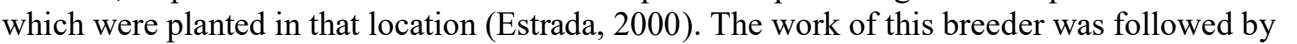

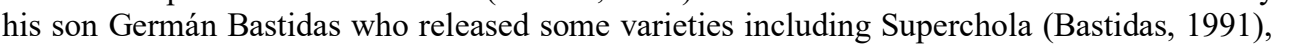

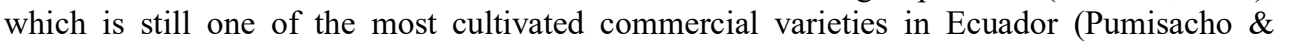

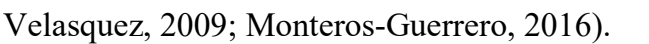

$\square$

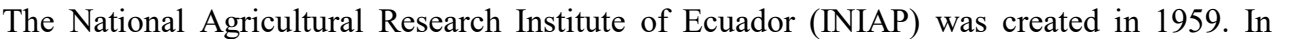

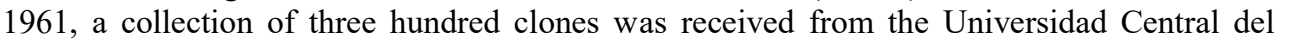

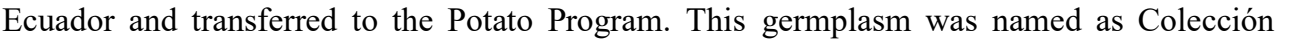

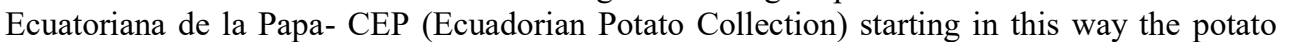

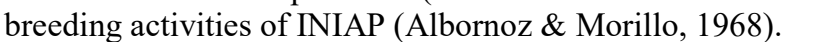

$\square$

\section{Breeding Objectives of INIAP's Potato Program $\square$}

$\square$

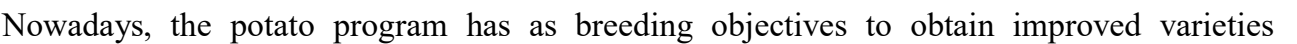

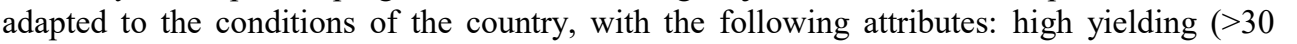

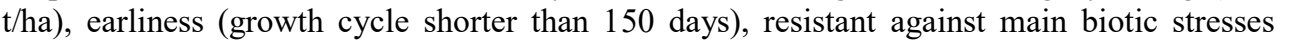

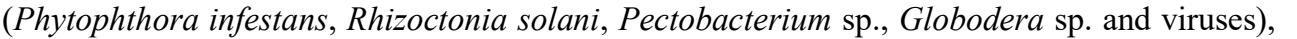

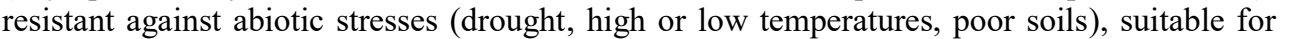

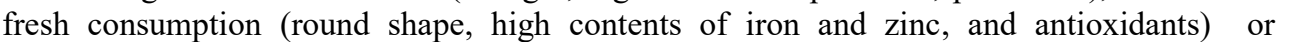

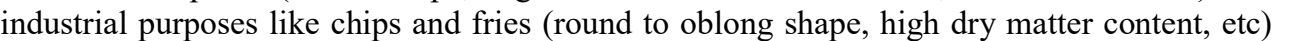

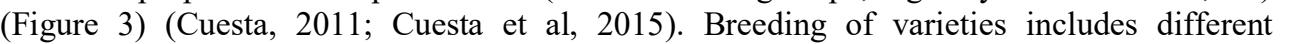




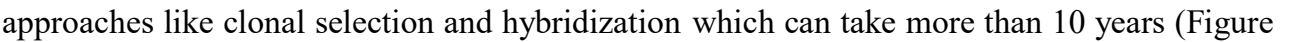
पाIIII

$\square$

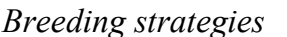

$\square$

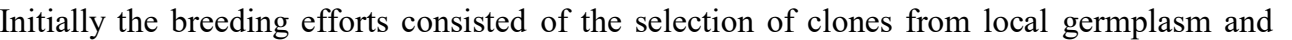

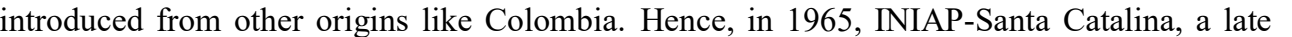

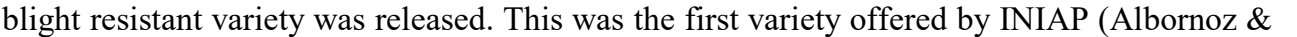

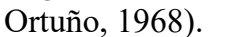

$\square$

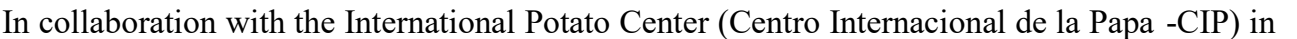

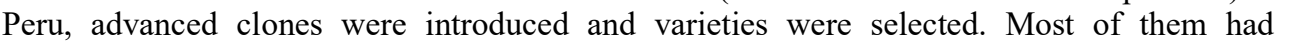

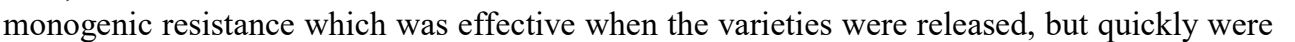

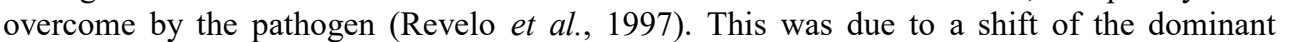

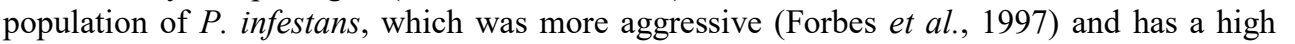

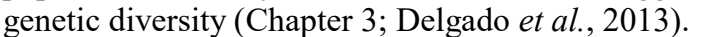

$\square$

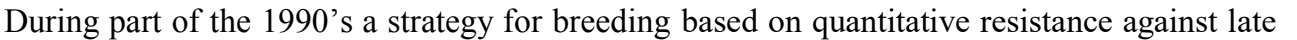

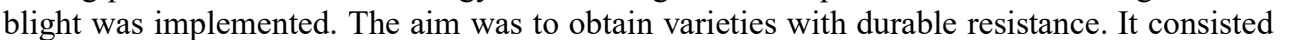

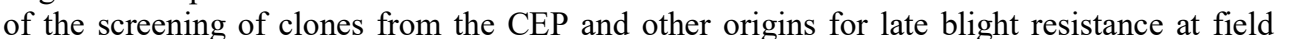

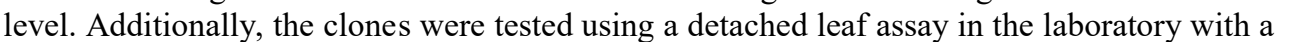

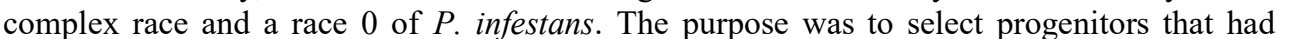

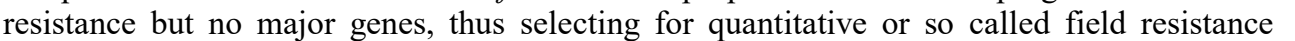

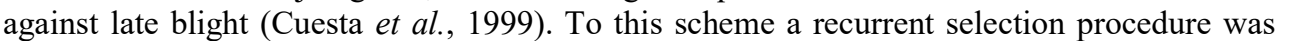

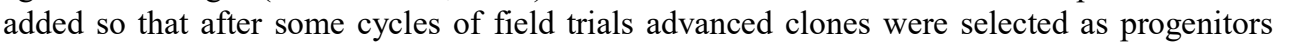

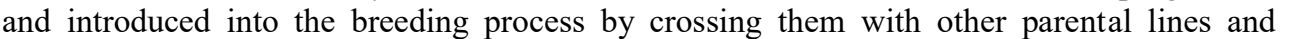

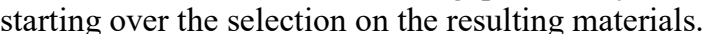

$\square$

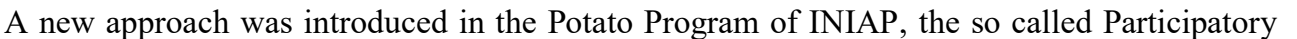

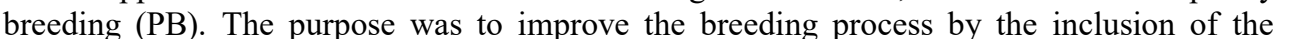

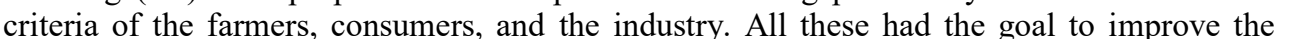

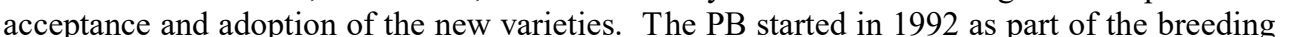

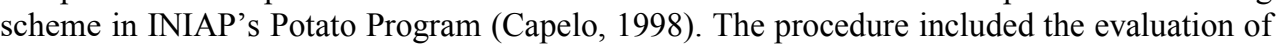

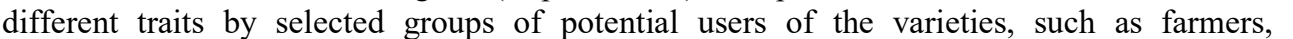

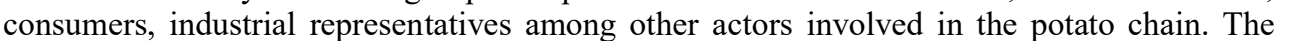

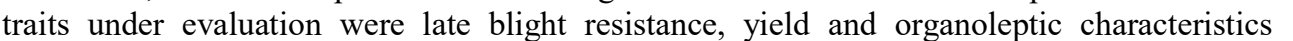

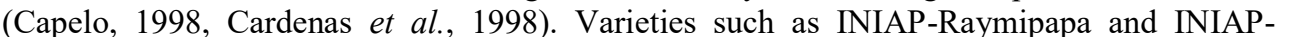

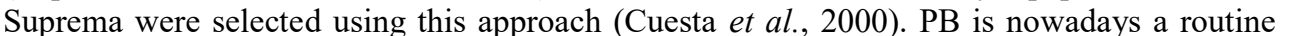
part of the breeding process carried out by INIAP's Potato Program. $\square$

$\square$

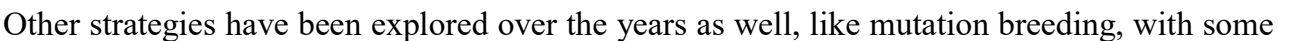

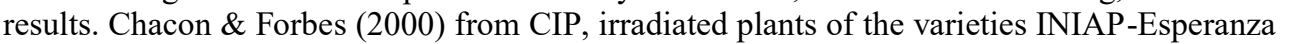

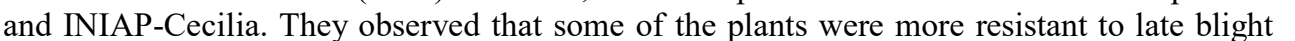

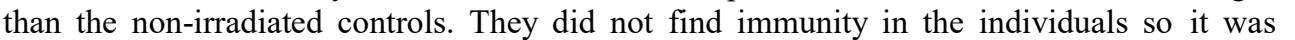

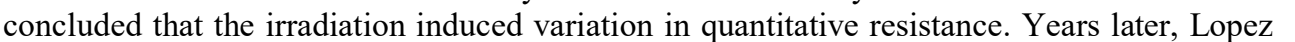

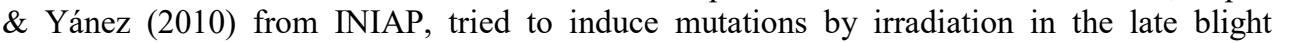

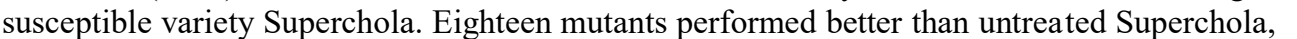




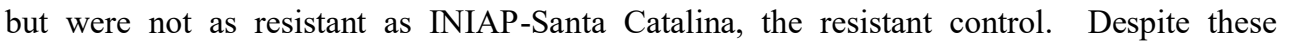

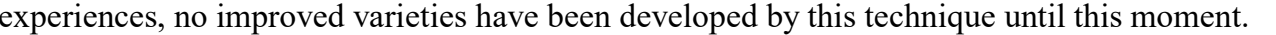

$\square$

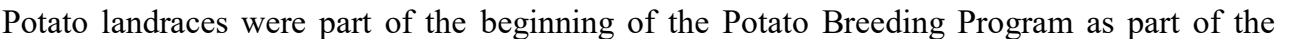

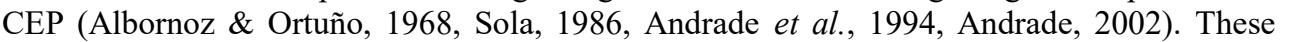

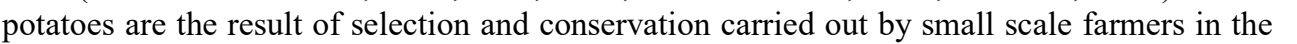

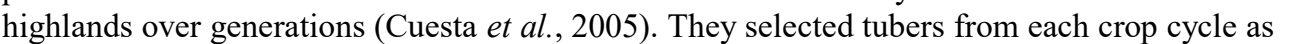

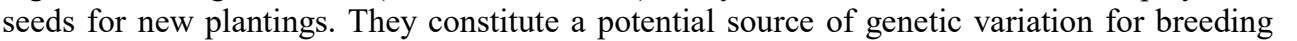

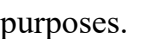

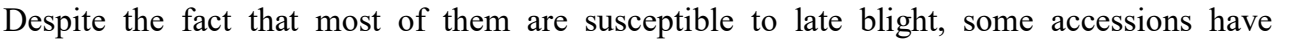

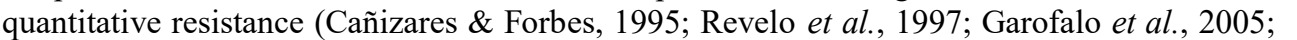

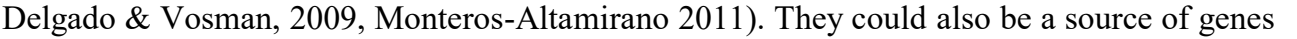
प

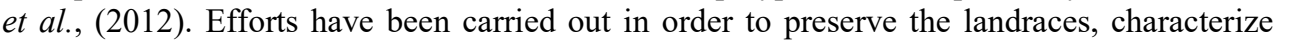

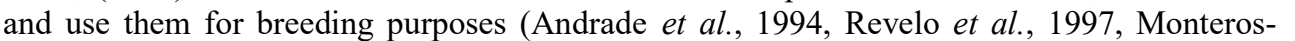

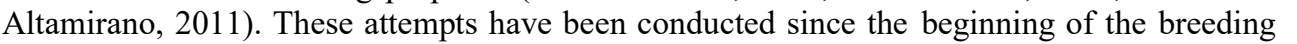

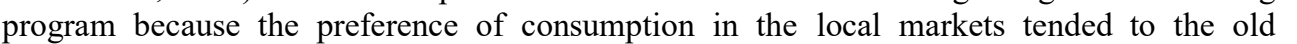
ए

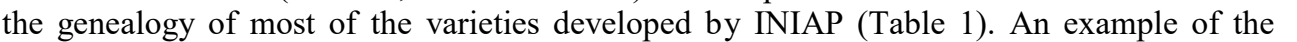

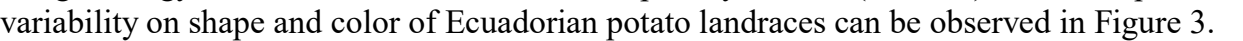
$\square$

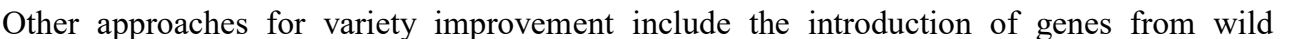

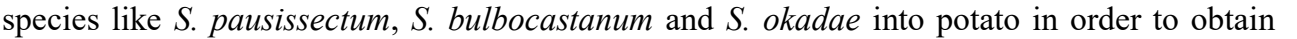

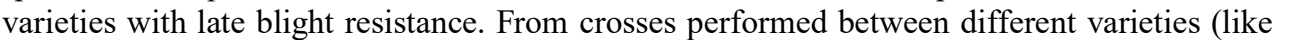

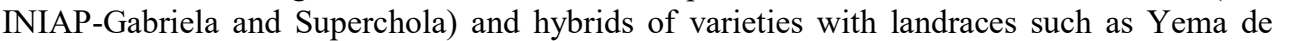

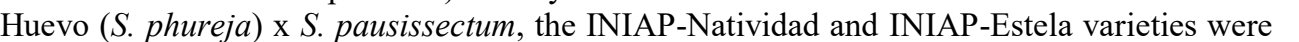

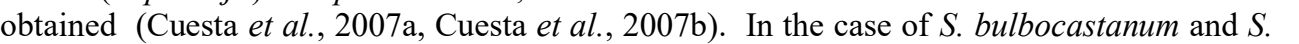

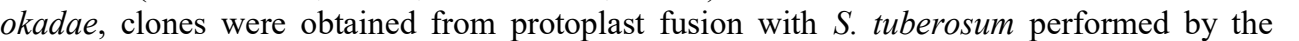

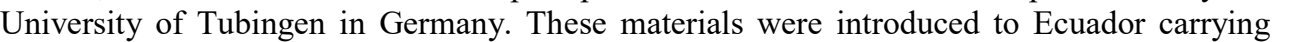

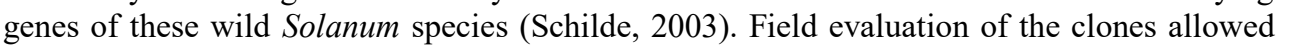
पा $\square$

\section{Discussion}

$\square$

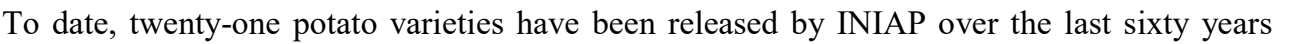

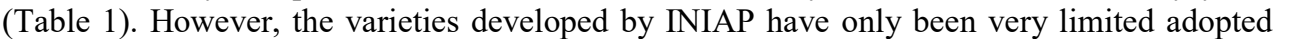

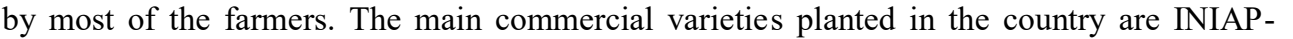

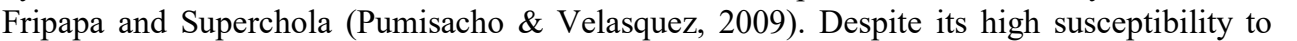

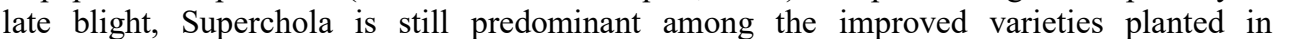

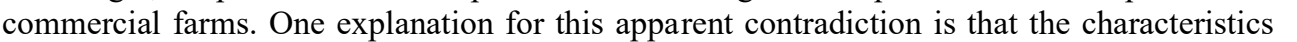

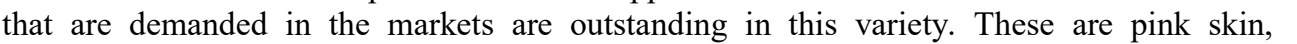

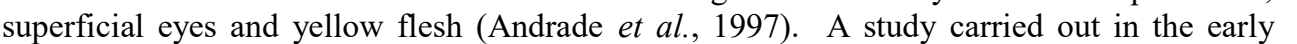

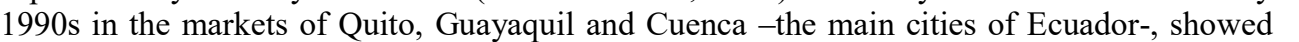

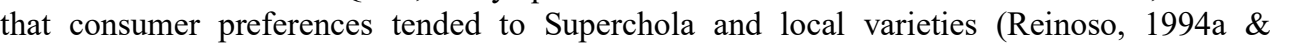

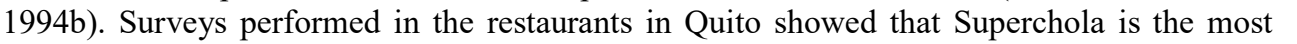

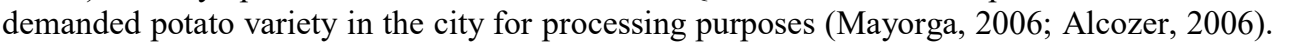

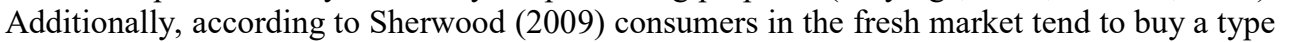




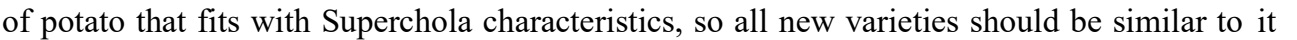

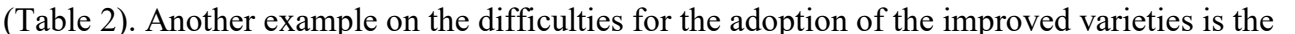

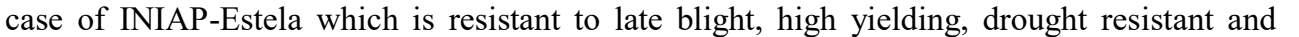

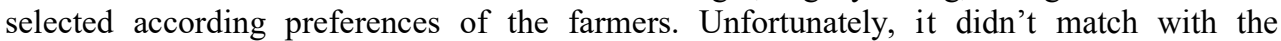

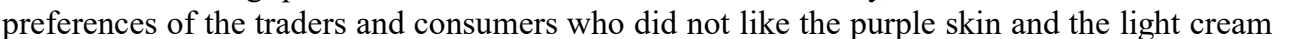

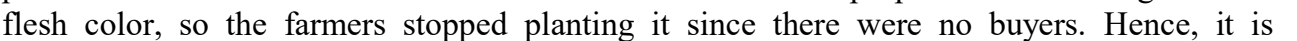

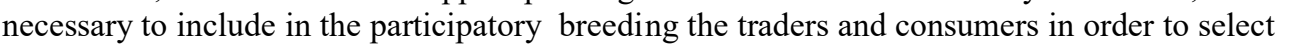

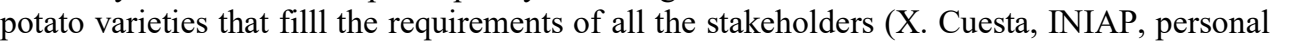

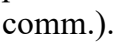

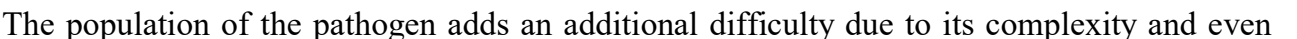

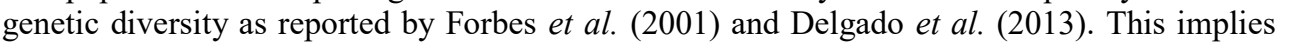

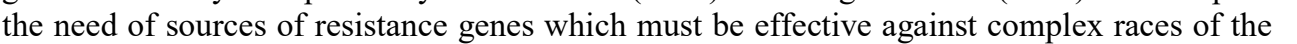

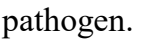

$\square$

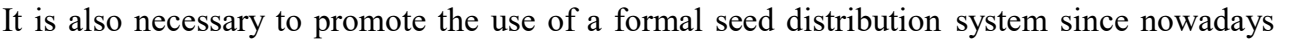

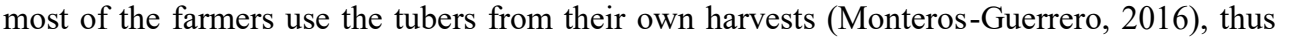

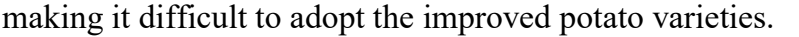

$\square$

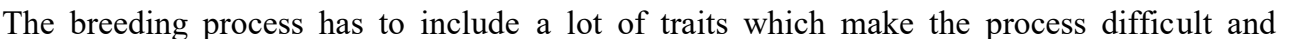

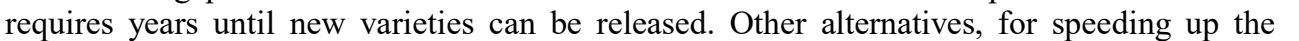

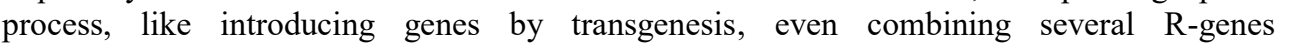

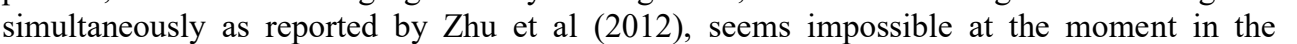
country. The present constitution, approved in 2008 in Article No. 401 expresses; 'Ecuador is declared as free of seeds and genetically modified crops', so this technique cannot be used.

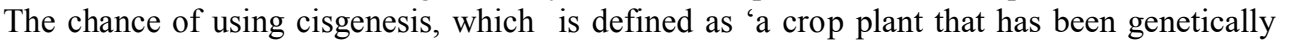

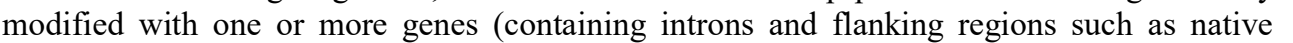
promoter and terminator regions in a sense orientation) isolated from a crossable donor plant' प

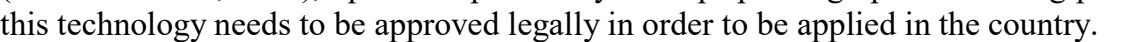

$\square$

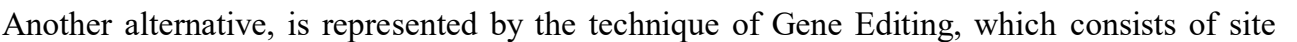

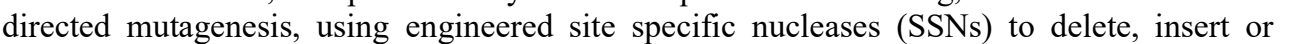

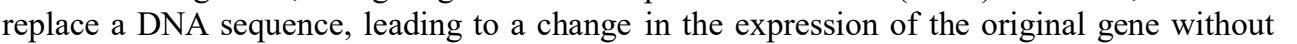

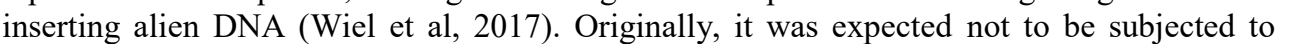
restrictions like those for GMO's. Despite the apparent advantages it has, recently, $\square[\|$

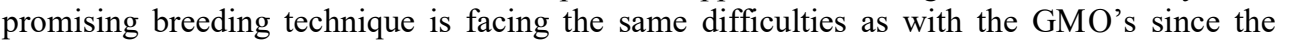

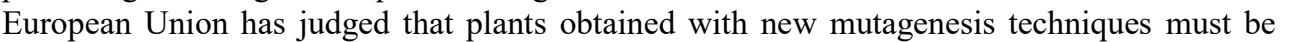

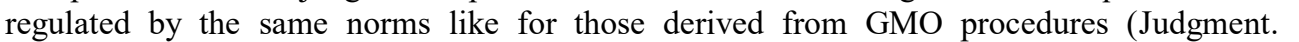

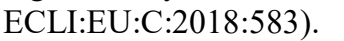

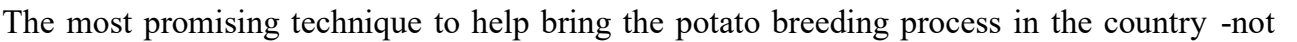
ए ए

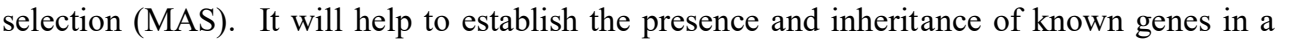

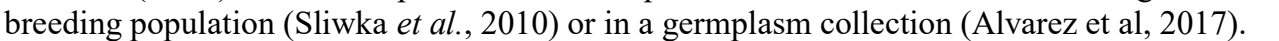




\title{
Final considerations and future perspectives
}

\begin{abstract}
$\square$

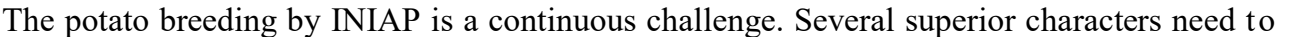

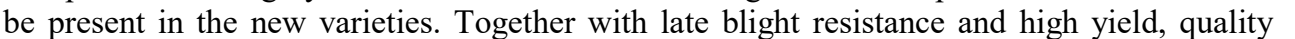

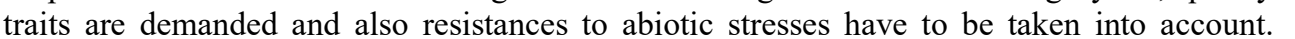

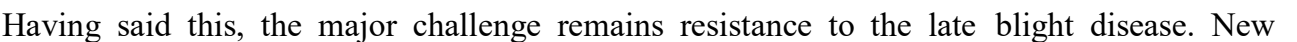

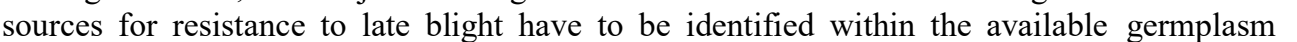

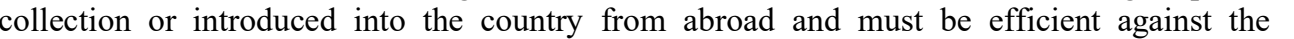

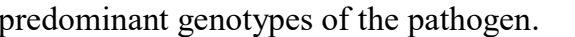

\section{Acknowledgements}

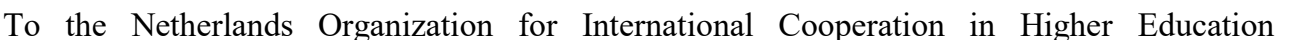

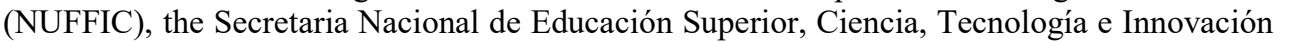

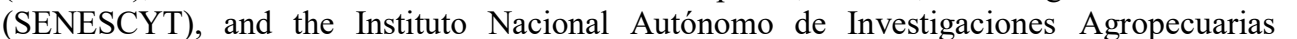

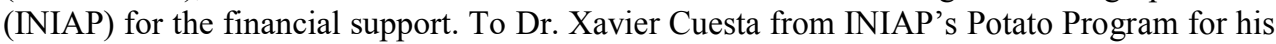

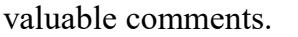

\section{Literature cited}

$\square$

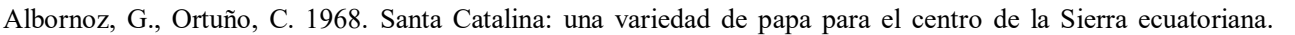

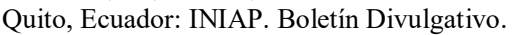

$\square$

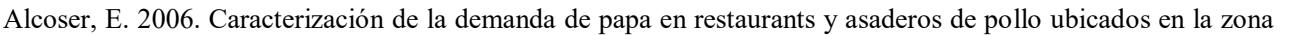

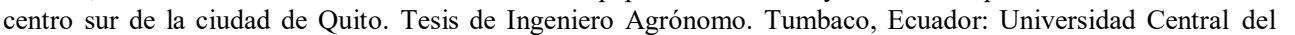
प्णा1ाणा

$\square$

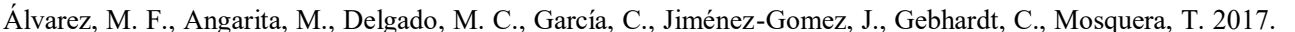
ए ए।

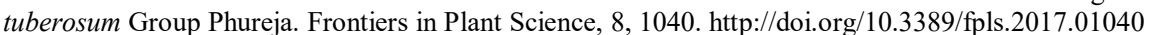

$\square$

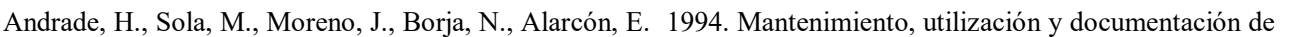

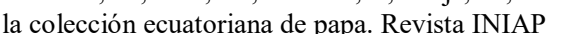
$\square$

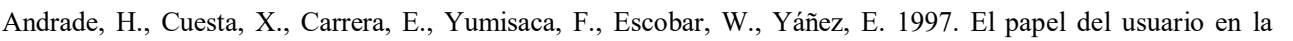

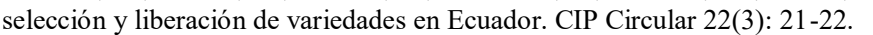
$\square$

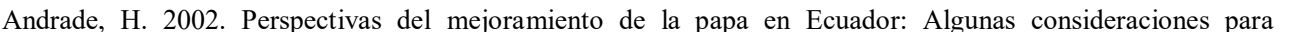

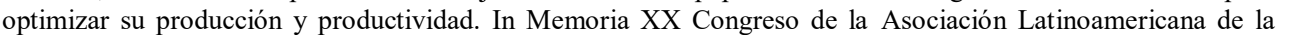

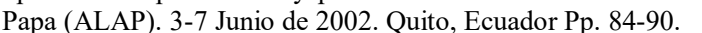
$\square$

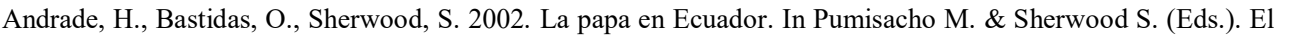

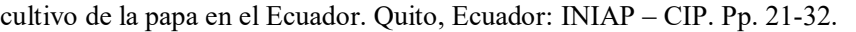
$\square$

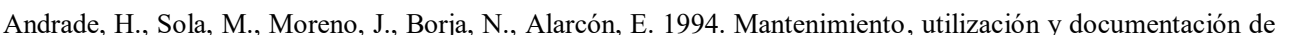

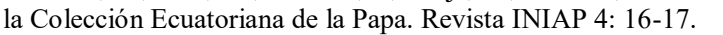
$\square$

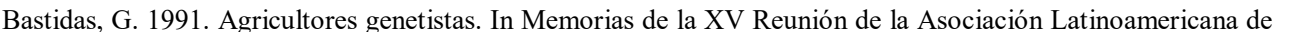

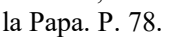


$\square$

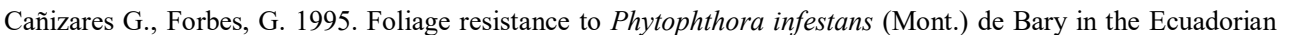

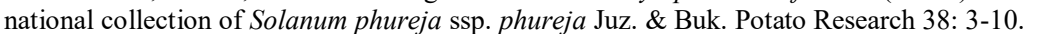
$\square$

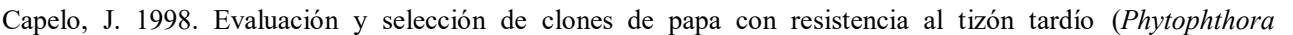

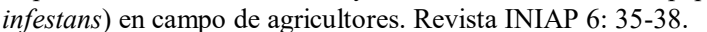

$\square$

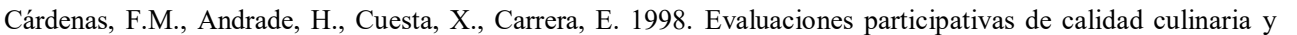

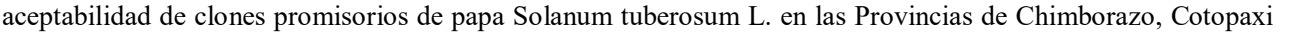

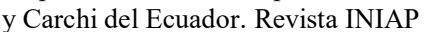

$\square$

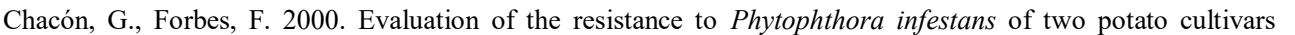

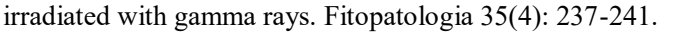

$\square$

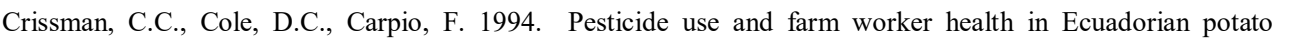

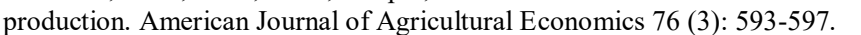

$\square$

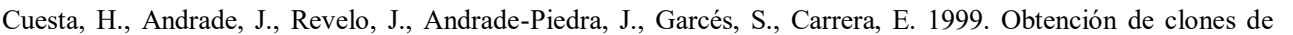

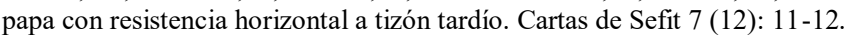
$\square$

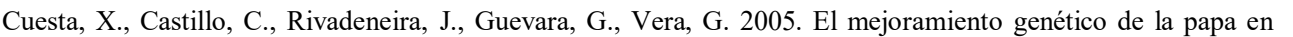

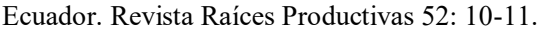

$\square$

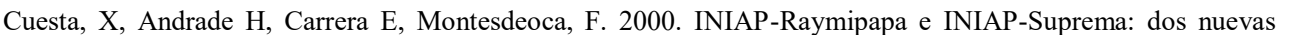

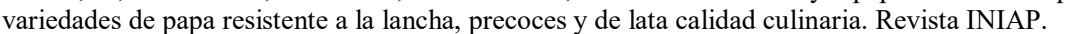
$\square$

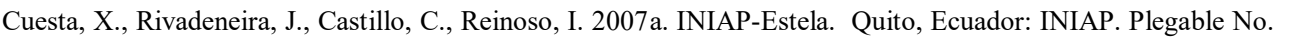
पाIा

$\square$

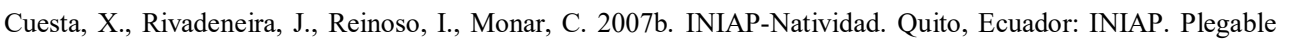
पणाणाणा

$\square$

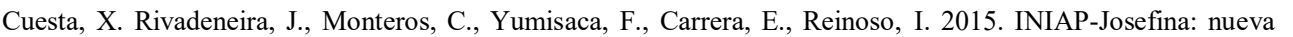

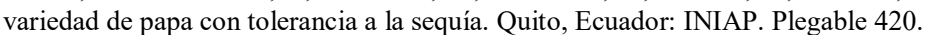

$\square$

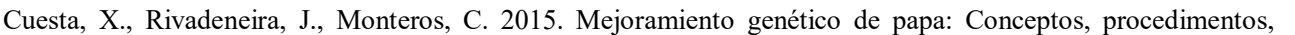

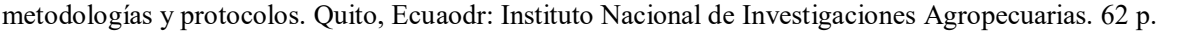
$\square$

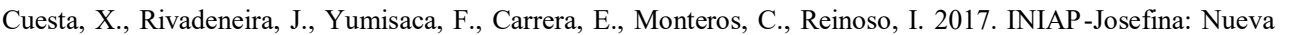

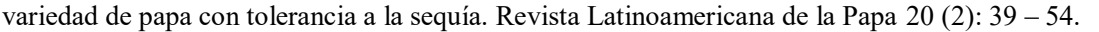
$\square$

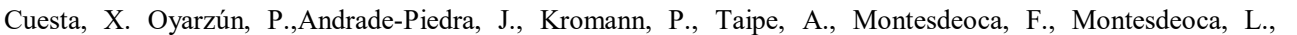

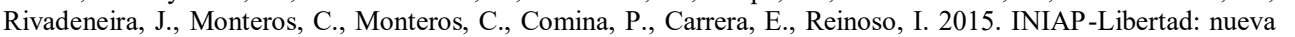

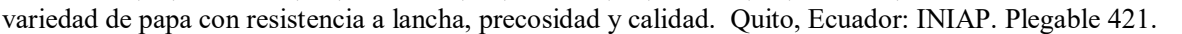
$\square$

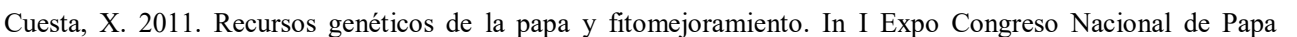

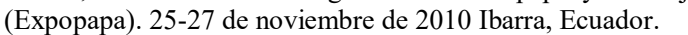
$\square$

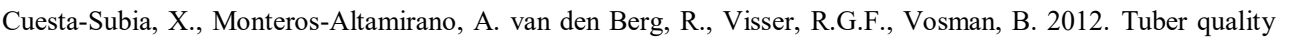

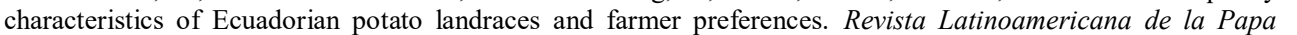
पाणाणाणण110 $\square$

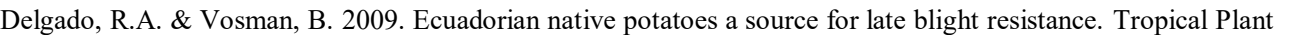

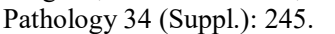

$\square$

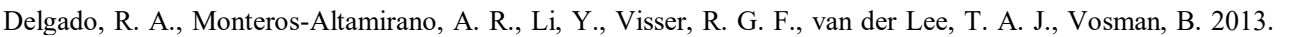

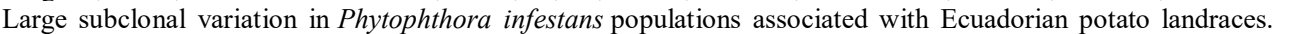

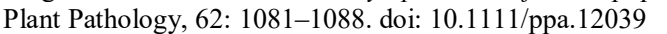

$\square$

$\square$ 


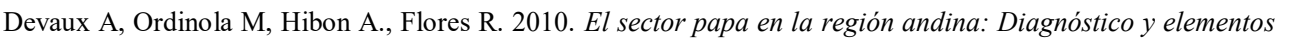

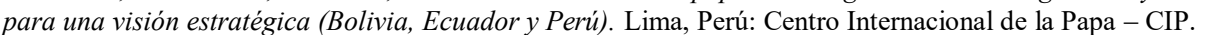
$\square$

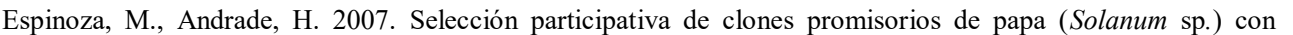

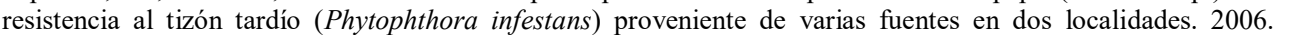

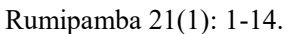

$\square$

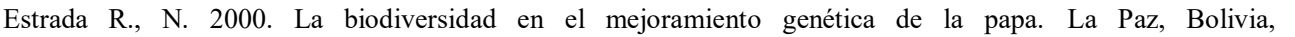

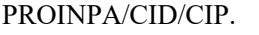

$\square$

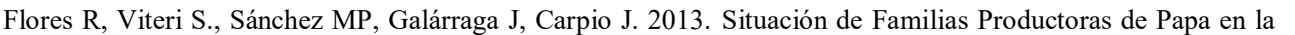

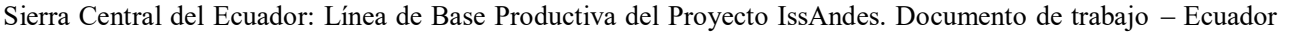

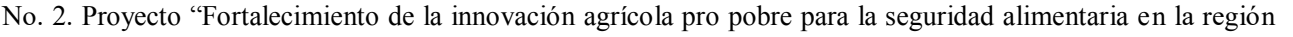
पIII-IssAndes". OFIAGRO, Centro Internacional de la Papa. Quito. 107 p $\square$

$\square$

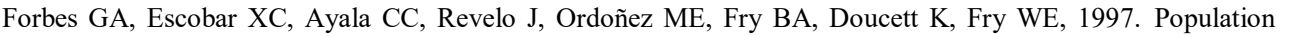

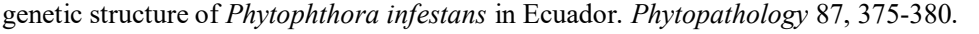

$\square$

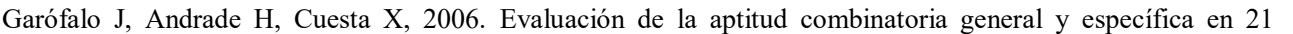

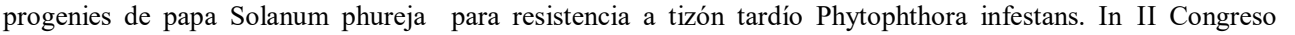

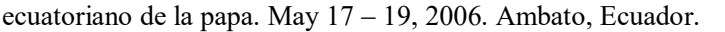

$\square$

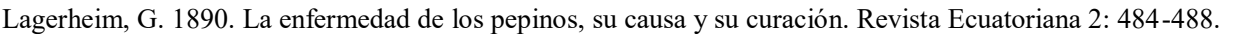

$\square$

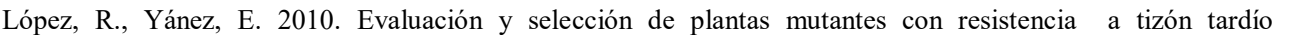

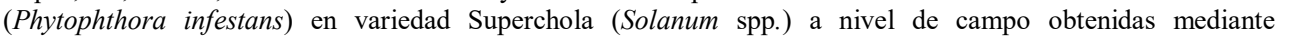
एणी $\square$

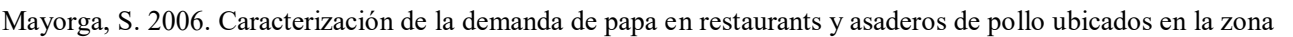

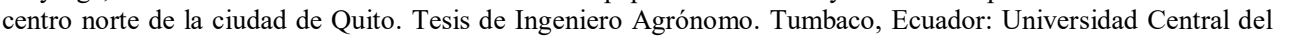
प्णाणाणा

$\square$

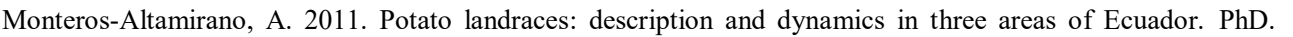

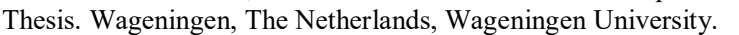

$\square$

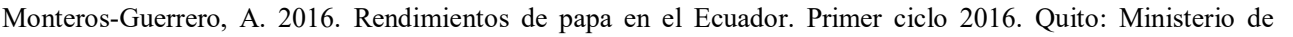

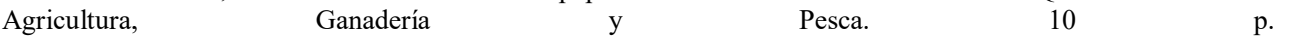

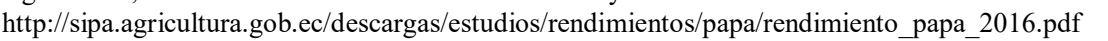

$\square$

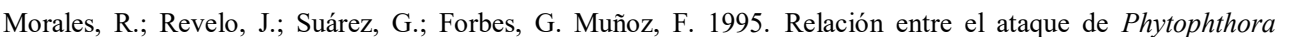

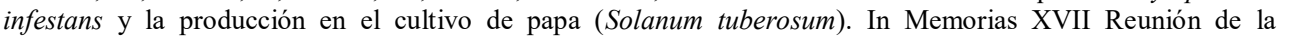

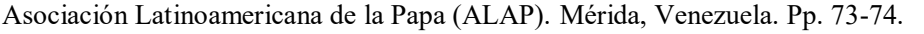

$\square$

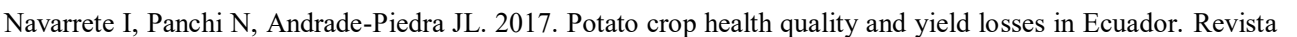

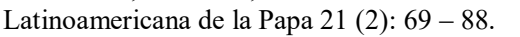

$\square$

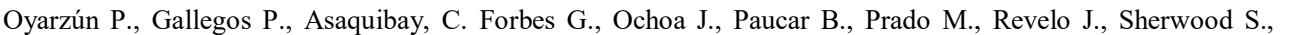

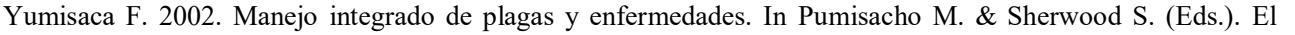

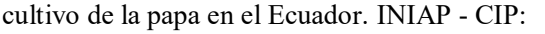

पाणाणा

$\square$

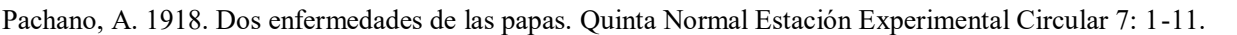
$\square$

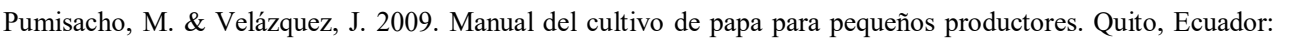

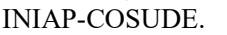

$\square$

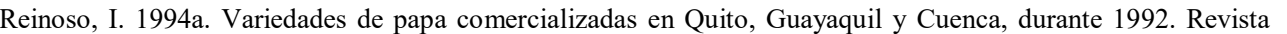

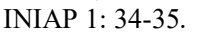

$\square$ 


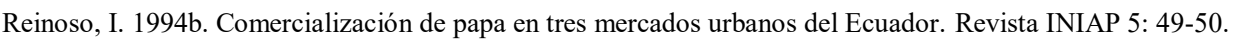
$\square$

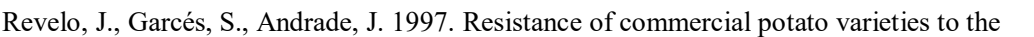

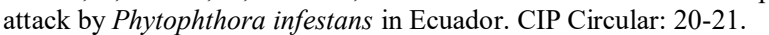

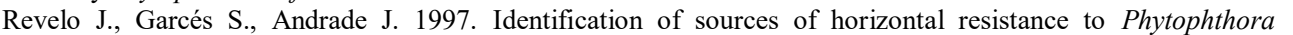

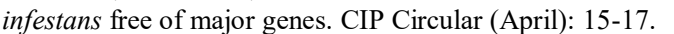

$\square$

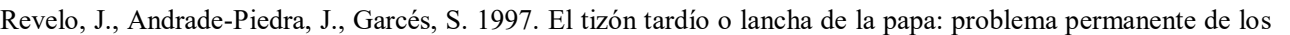
agricultores. In Memorias del Curso: 'Manejo integrado de las principales plagas y enfermedades del cultivo de

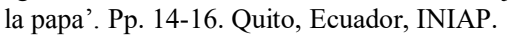

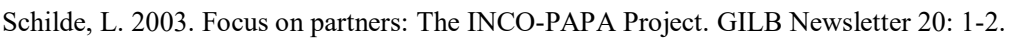
$\square$

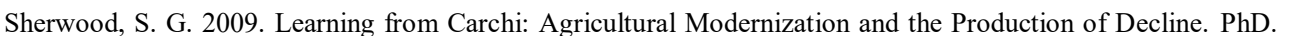

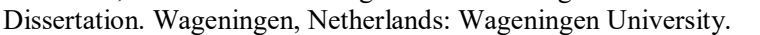
$\square$

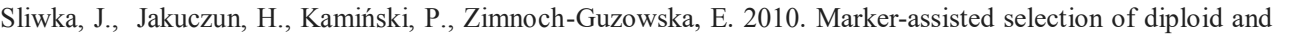

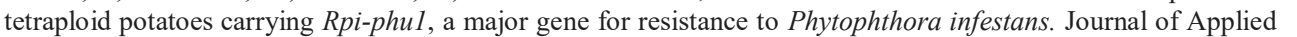

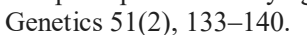
$\square$

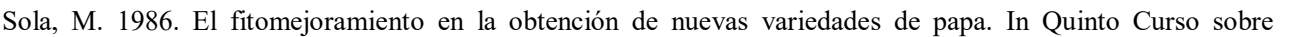

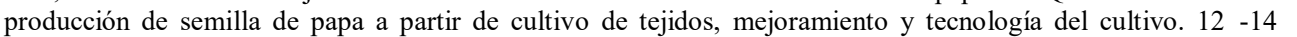

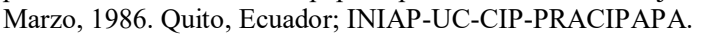
$\square$

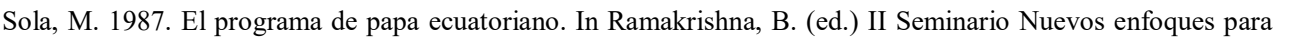

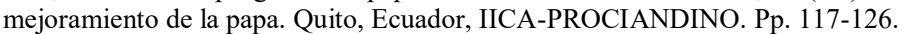
$\square$

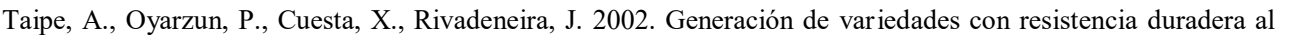

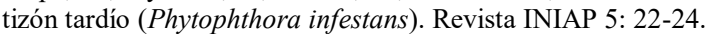
$\square$

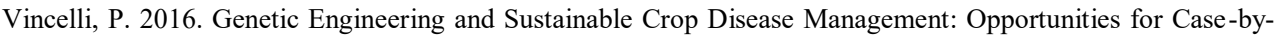

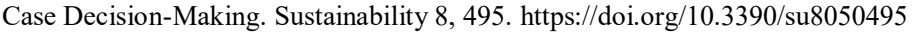
$\square$

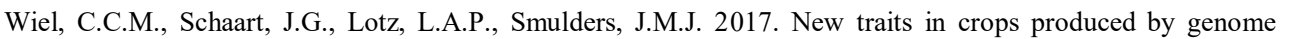

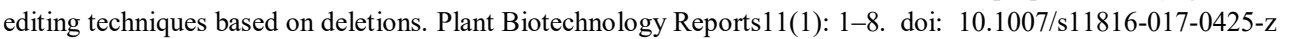

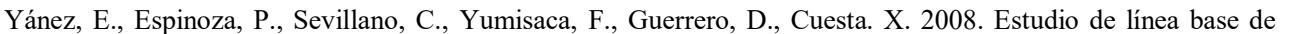

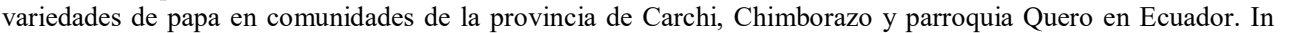

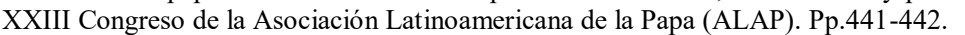
$\square$

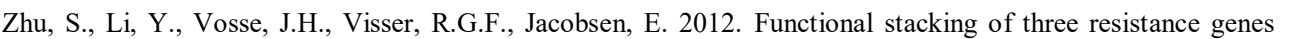

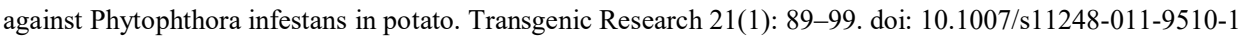




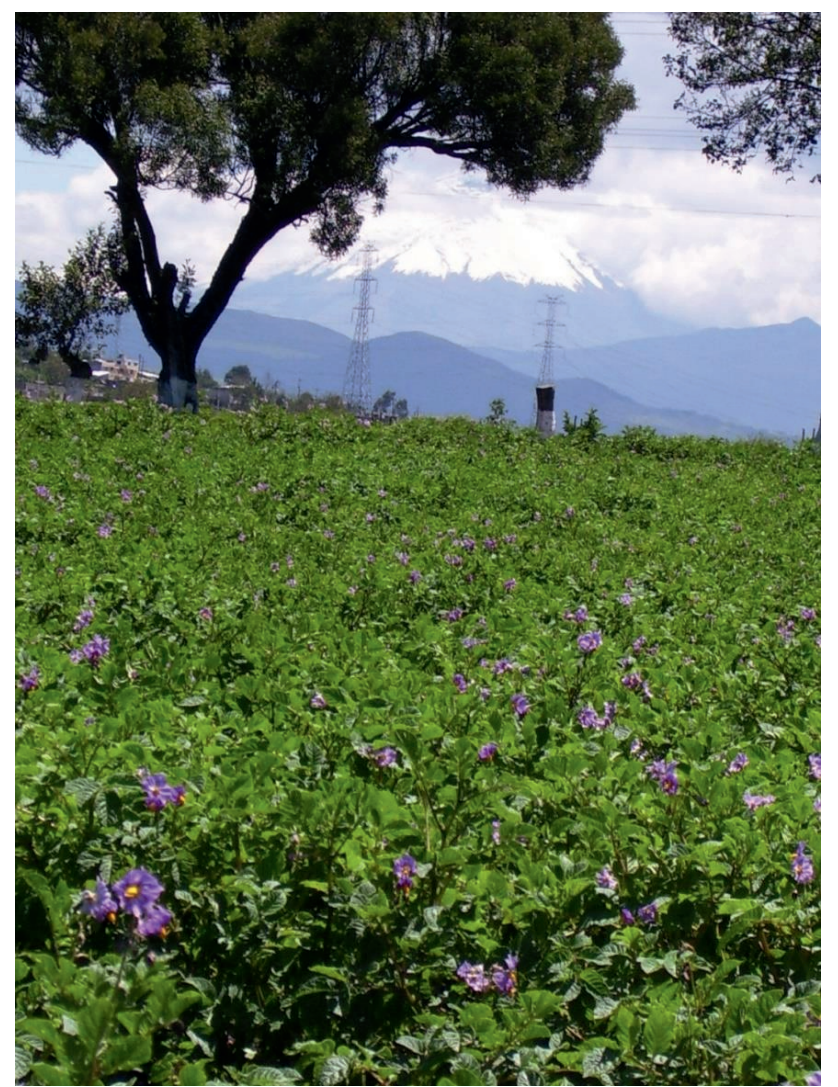

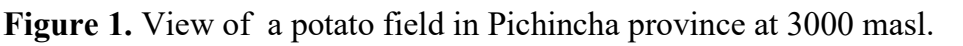




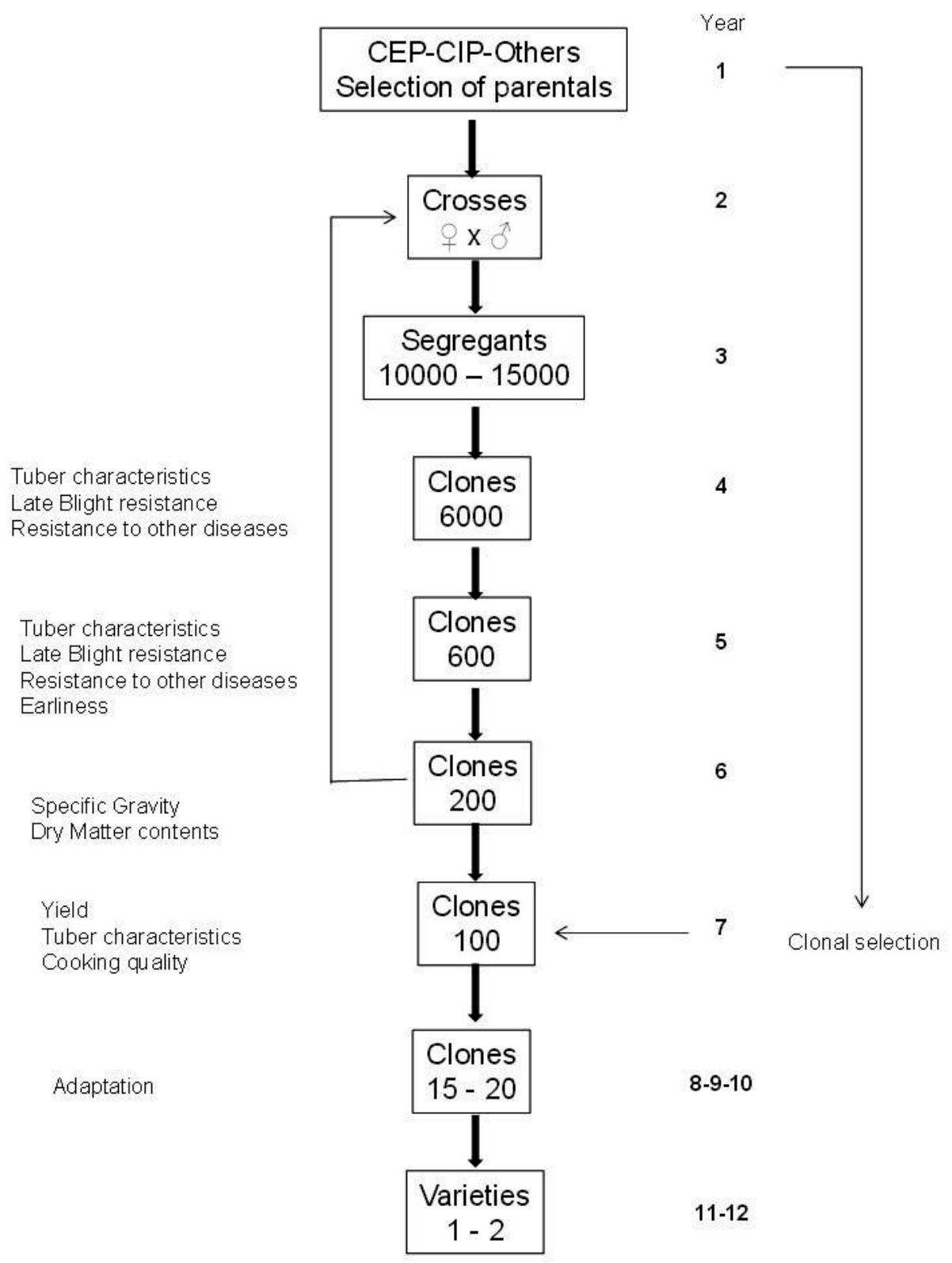

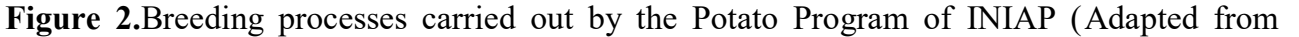

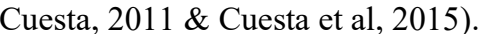




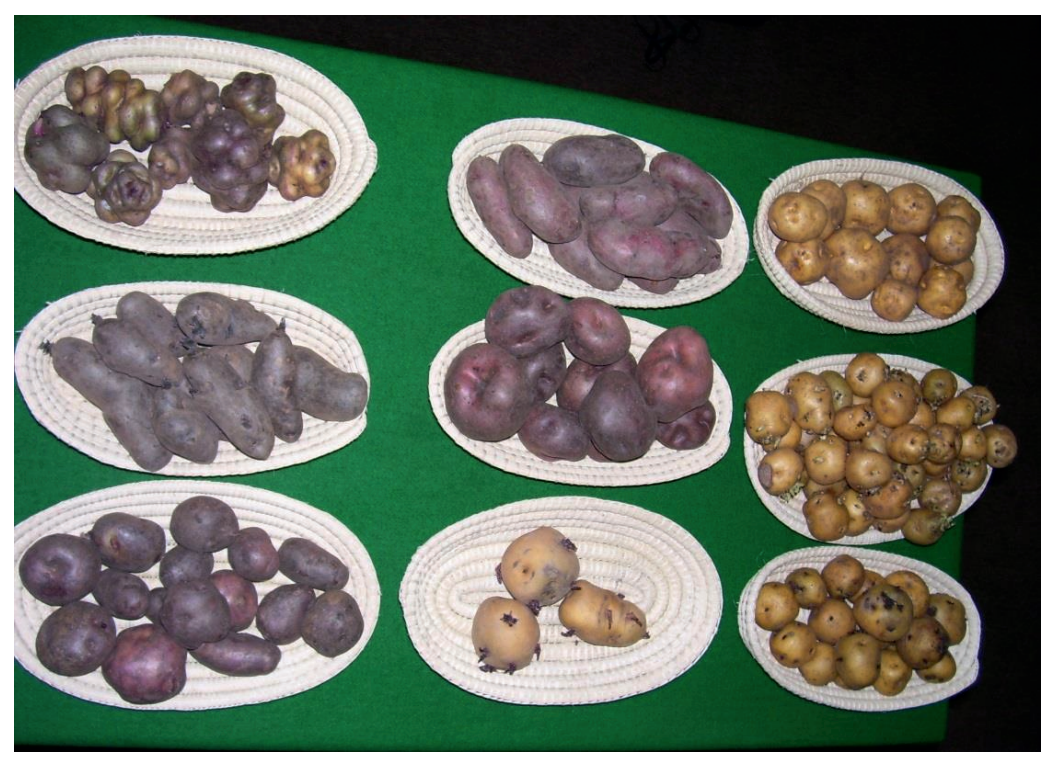

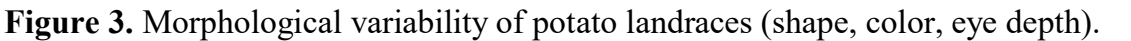

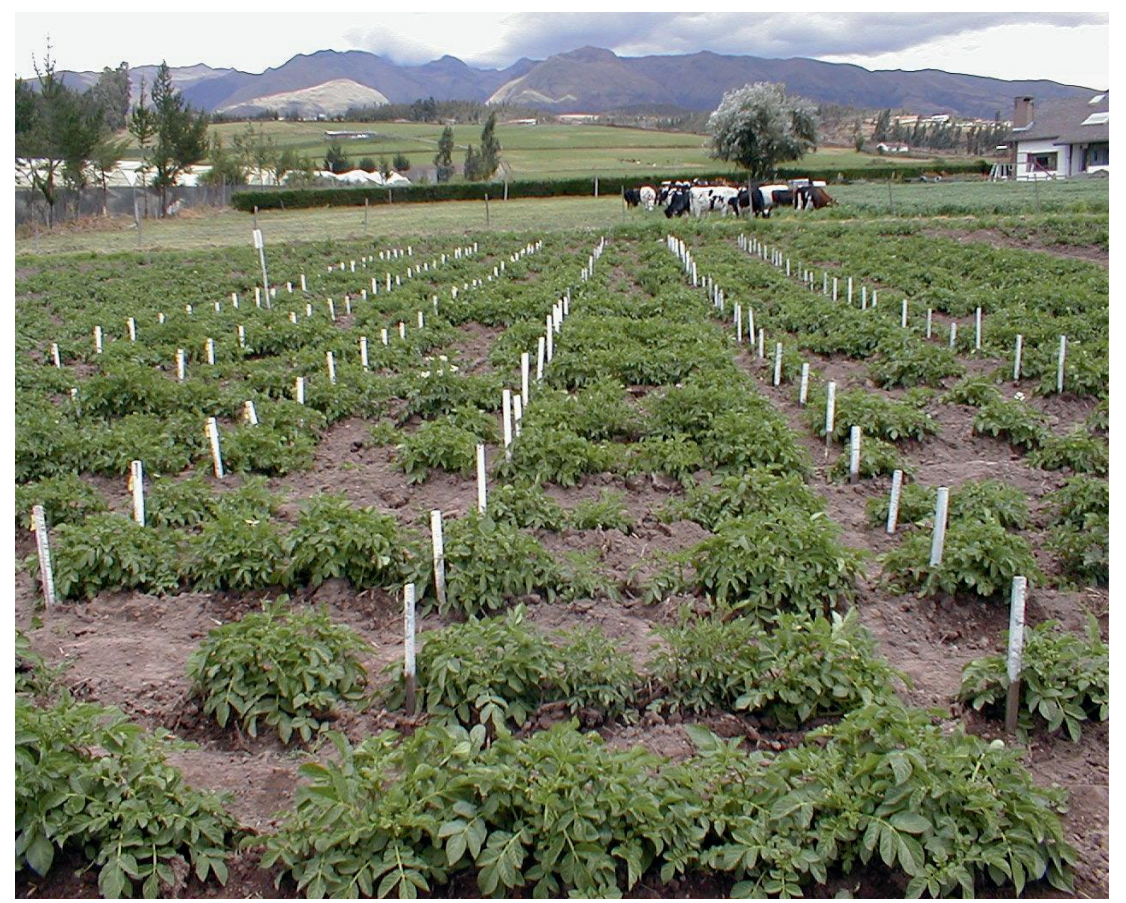

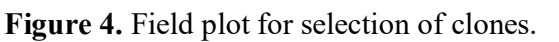


Table 1.

\begin{tabular}{|c|c|c|c|c|c|}
\hline Name $\square$ & Genealogy & Release & $\begin{array}{c}\text { Potential Yield } \\
\text { (t/ha) }\end{array}$ & $\begin{array}{l}\text { Resistance to } \\
\text { Late blight }\end{array}$ & $\begin{array}{l}\text { Presence of } \\
\text { R genes* }\end{array}$ \\
\hline 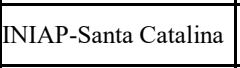 & 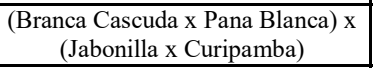 & $\square 11$ & $\square$ & $\square \square$ & $\square \square$ \\
\hline 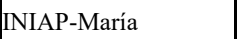 & 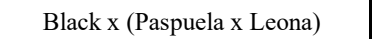 & $\square 11$ & $\square \square$ & $\square \square \square$ & $\square \square$ \\
\hline 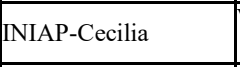 & 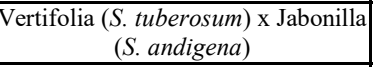 & $\square 11$ & $\square$ & $\square \square \square$ & $\square \square$ \\
\hline 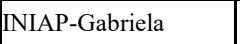 & 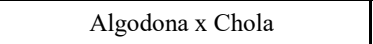 & $\square 11$ & $\square$ & $\square$ & $\square \square$ \\
\hline 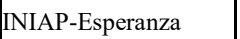 & पणमाणाणमाण & $\square \Pi 1$ & $\square \square$ & $\square$ & $\square \square$ \\
\hline 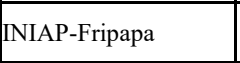 & 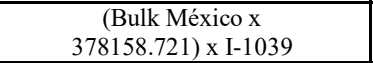 & $\square \Pi \square$ & $\square$ & $\square \square$ & $\square \square$ \\
\hline 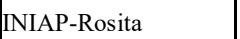 & 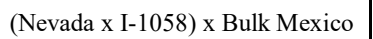 & $\square \Pi \square$ & $\square \square$ & $\square \square$ & $\square \square$ \\
\hline 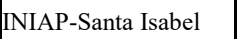 & 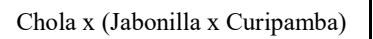 & $\square 11$ & $\square \square$ & $\square$ & $\square \square$ \\
\hline 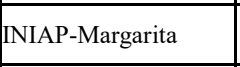 & 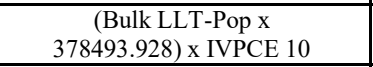 & $\square 11$ & $\square$ & $\square \square$ & $\square \square$ \\
\hline 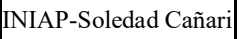 & 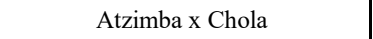 & $\square \Pi 1$ & $\square$ & $\square$ & $\square \square$ \\
\hline 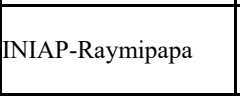 & 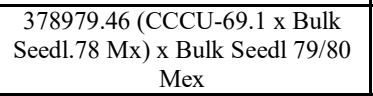 & $\square 1 \square$ & $\square$ & $\square \square$ & $\square \square$ \\
\hline 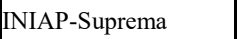 & 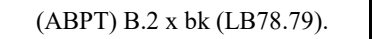 & $\square 11$ & $\square$ & $\square \square \square$ & $\square \square$ \\
\hline 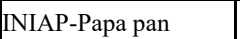 & $\square \square 11 \square$ & $\square 11$ & $\square \square$ & $\square \square \square$ & $\square \square$ \\
\hline 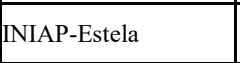 & 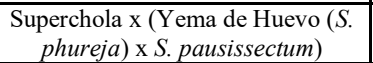 & $\square 11$ & $\square$ & $\square \square$ & पणाण \\
\hline 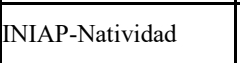 & 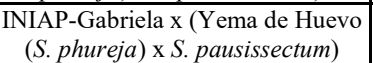 & $\square \Pi 1$ & $\square$ & $\square \square \square$ & पणाण \\
\hline 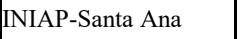 & 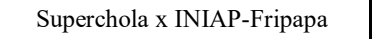 & $\square 11$ & $\square$ & $\square \square \square$ & पणाप \\
\hline 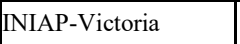 & 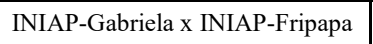 & $\square 11$ & $\square$ & $\square \square \square$ & पणाप \\
\hline 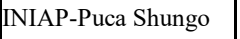 & 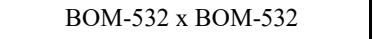 & $\square 1 \square$ & $\square \square$ & $\square \square \square$ & पापाप \\
\hline 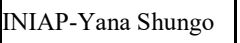 & 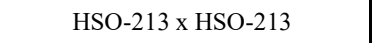 & $\square 1 \square$ & $\square \square$ & $\square \square \square$ & पणाए \\
\hline 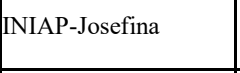 & 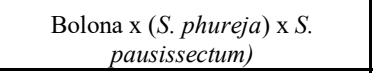 & $\square 11$ & पाण & $\square \square \square$ & पणाप \\
\hline 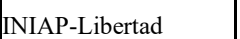 & $\square \square \square$ & $\square \Pi \square$ & $\square 101 \square$ & $\square \square$ & $\square ण$ \\
\hline
\end{tabular}

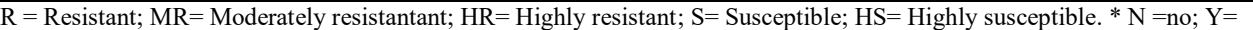
प110 
Table 2.

\begin{tabular}{|c|c|c|c|}
\hline Name & Release & Skin & Flesh \\
\hline 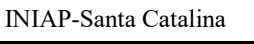 & $\square 11$ & $\square \amalg \square \square$ & $\square \square ण \square \square$ \\
\hline 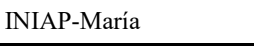 & $\square 111$ & $\square \square \amalg \square$ & $\square \square \square$ \\
\hline 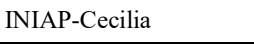 & $\square 1 \square$ & 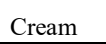 & $\square \square \square \square$ \\
\hline 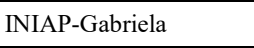 & $\square \Pi \square$ & $\square[110$ & $\square \square \| \square \square$ \\
\hline 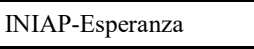 & $\square \Pi \square$ & $\square \square \square \square$ & $\square \square \| \square \square$ \\
\hline 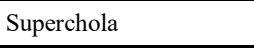 & $\square \prod \square$ & $\square[11$ & पणापण \\
\hline प⿴囗十丁口卄ा & $\square 11$ & 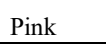 & $\square \square \square \square \square$ \\
\hline 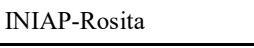 & $\square 11$ & $\square \square \square$ & $\square \square ण 1 \square \square$ \\
\hline 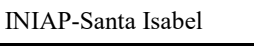 & $\square \Pi 1$ & $\square \square \square$ & 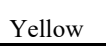 \\
\hline 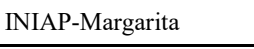 & $\square 11$ & 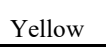 & $\square \square \| \square \square$ \\
\hline 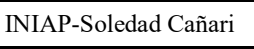 & $\square 11$ & $\square \square \square \square$ & 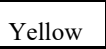 \\
\hline 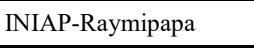 & $\square \prod \square$ & $\square \square \square \square$ & 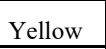 \\
\hline 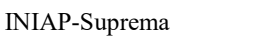 & $\square 11 \square$ & पणमा & $\square \square \square \square$ \\
\hline प⿴囗十丁口卄ामाया & $\square 11$ & $\square \square \| \square$ & $\square \square \square \square$ \\
\hline 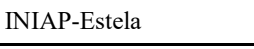 & $\square 110$ & पापाणा & 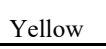 \\
\hline 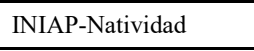 & $\square \prod \square$ & 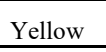 & 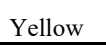 \\
\hline 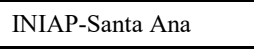 & $\square \Pi \square$ & $\square \square ण म \square$ & $\square \square ण \square \square$ \\
\hline 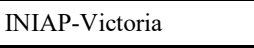 & $\square 11$ & पण口 & पमणाप \\
\hline 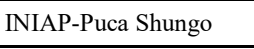 & $\square \Pi \square$ & 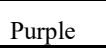 & $\square \square$ \\
\hline 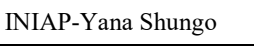 & $\square 11$ & $\square \square \square \square$ & 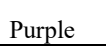 \\
\hline 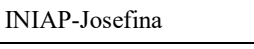 & $\square \Pi$ & $\square \square \square$ & पणाए \\
\hline 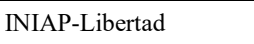 & $\square 10$ & 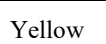 & पण口ण \\
\hline
\end{tabular}




\title{
Chapter 3
}

\section{Large sub-clonal variation in Phytophthora infestans populations associated} to Ecuadorian potato landraces

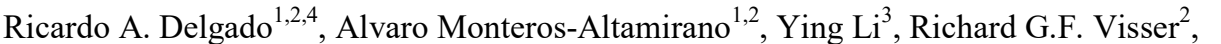

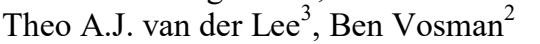

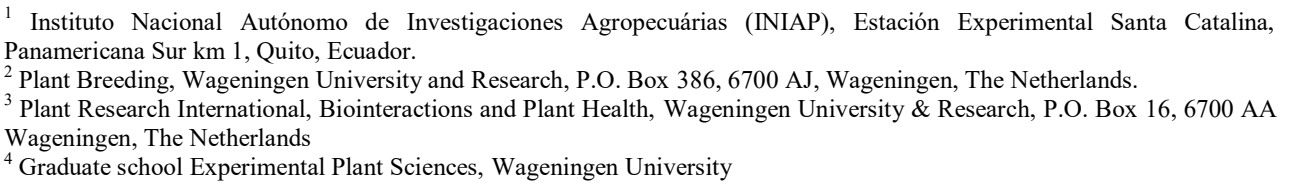

Published in Plant Pathology (2013) 62, 1081-1088

\begin{abstract}

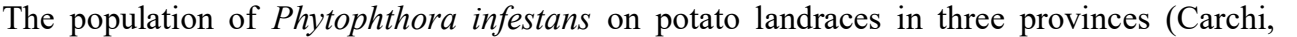

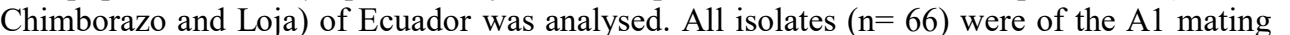

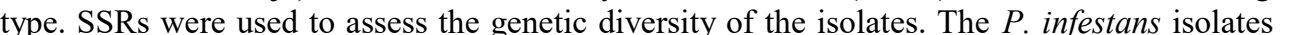

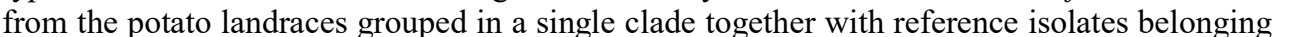
ए

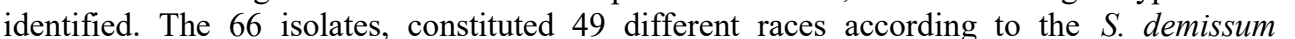

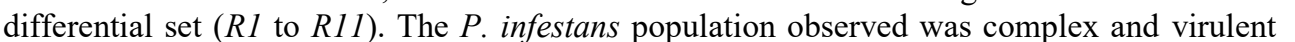

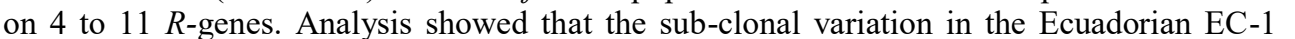

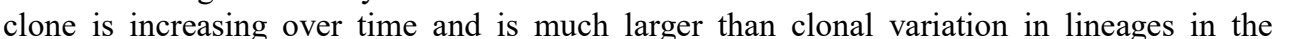

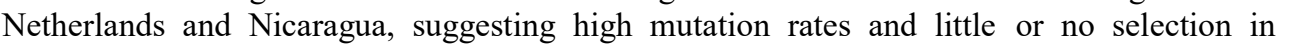

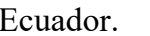

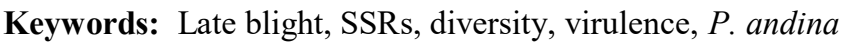




\section{Introduction}

$\square$

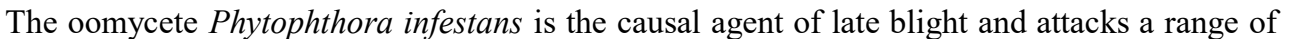

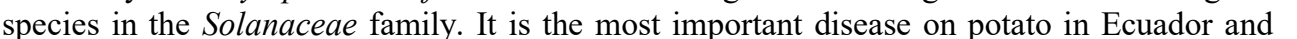

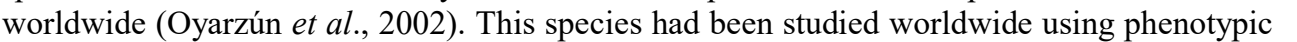

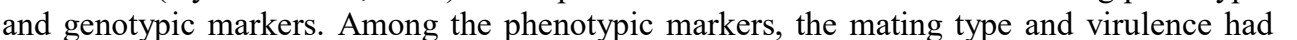

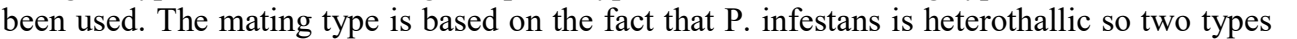

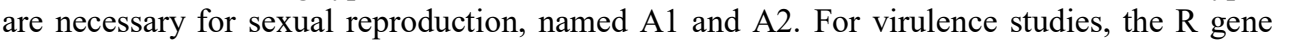

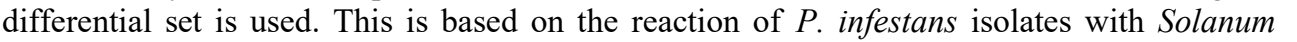
पण

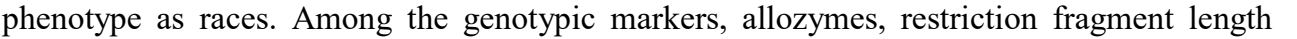

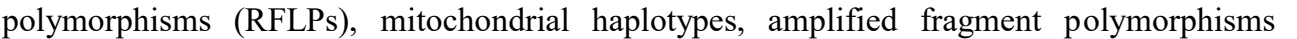

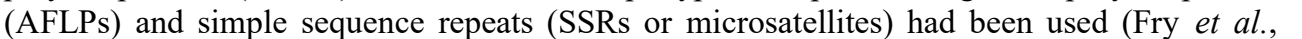

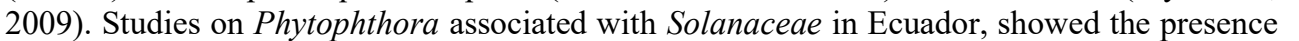

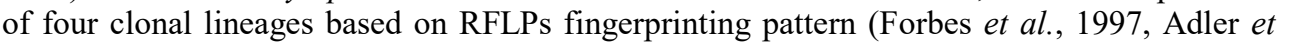

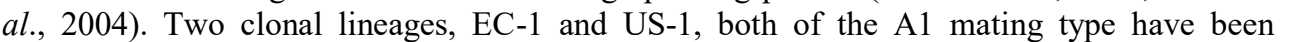

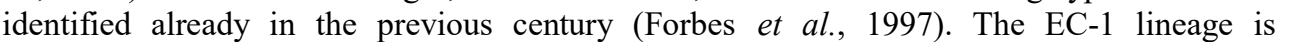

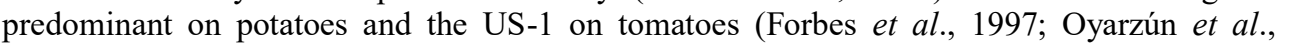

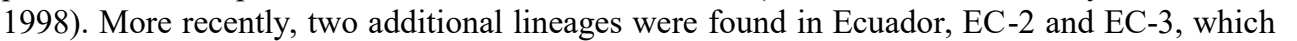

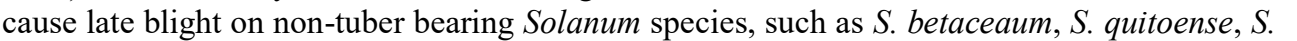

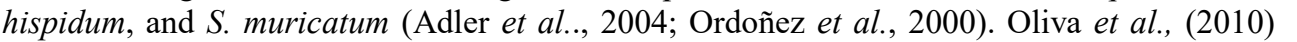

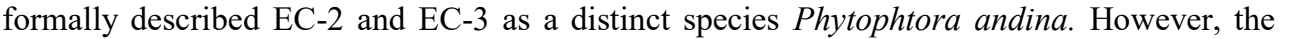

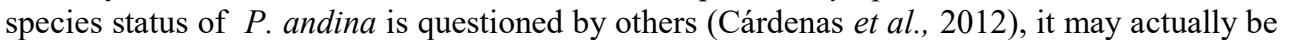

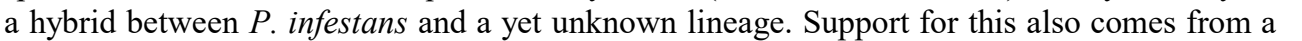

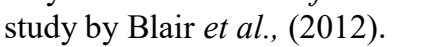

$\square$

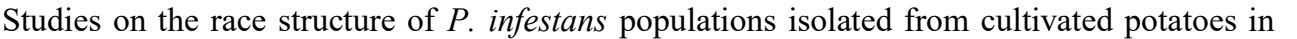

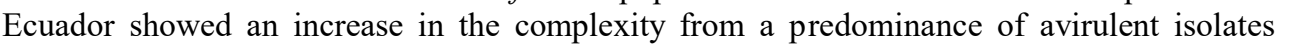

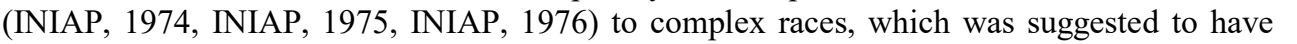

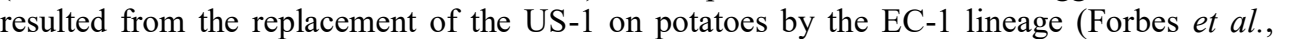

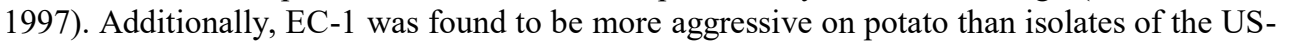

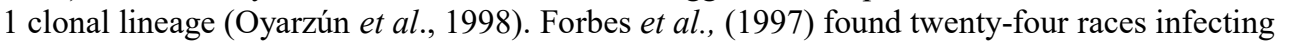

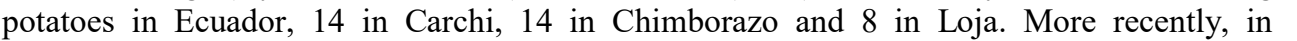

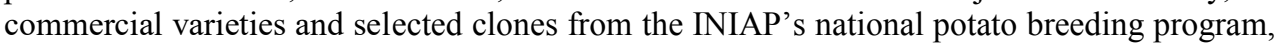

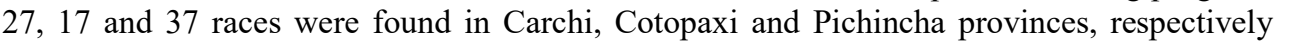

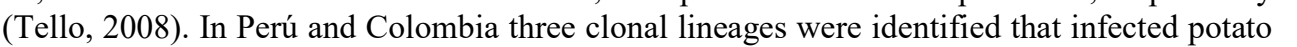

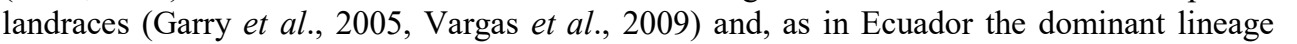

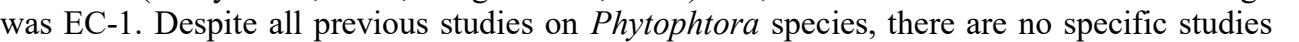

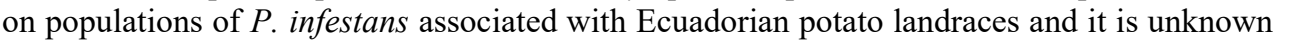

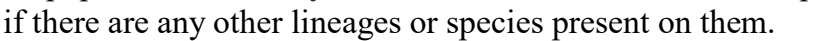

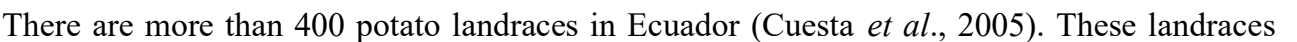

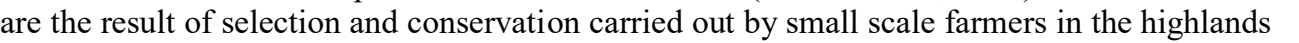

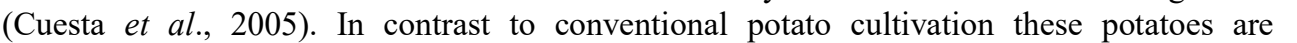

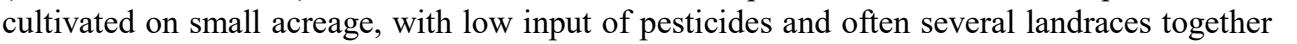

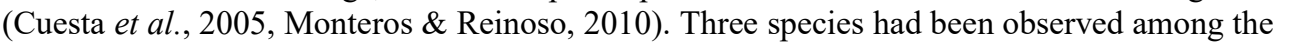

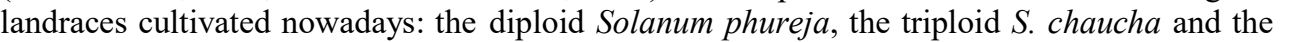




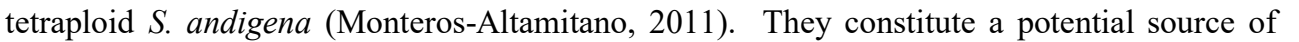

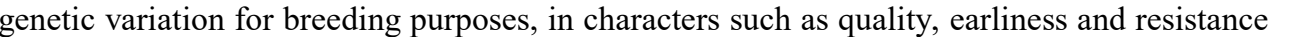
ए

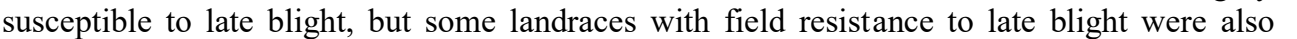

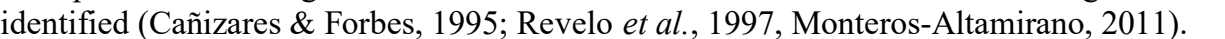

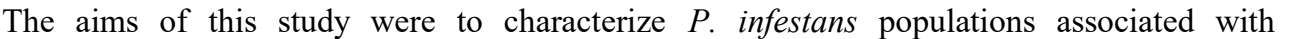

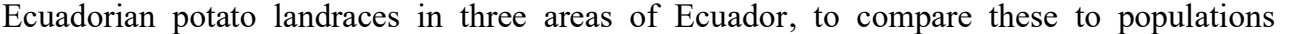

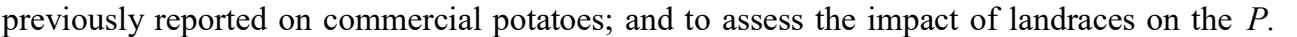

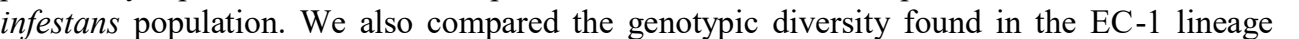

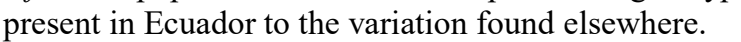

$\square$

\section{Materials and methods}

$\square$

$\square$

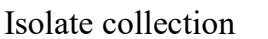

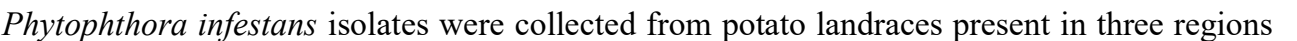

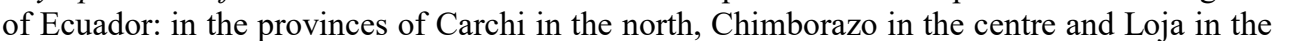

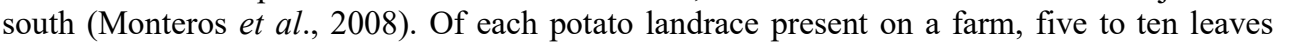

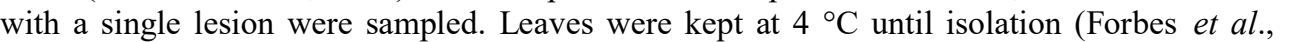

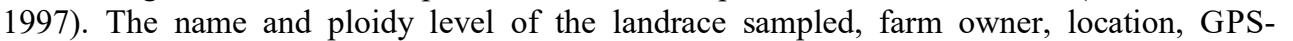
प

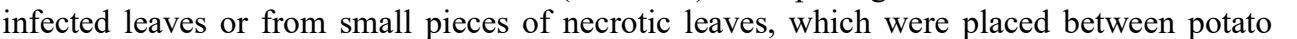

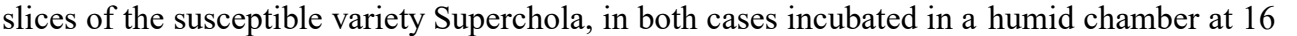

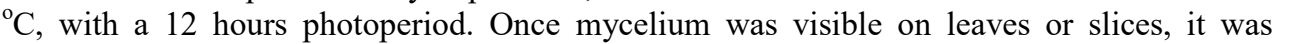

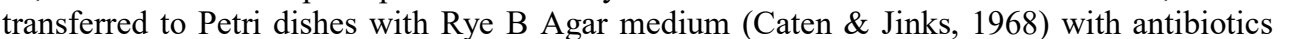

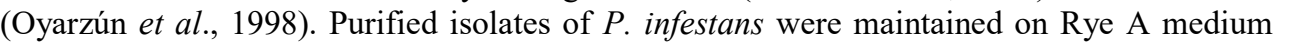

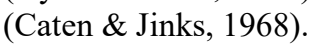

$\square$

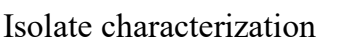

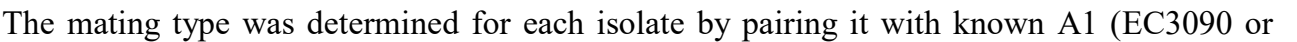

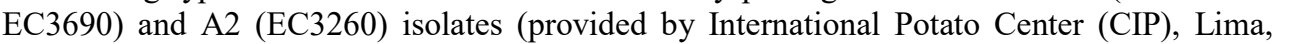

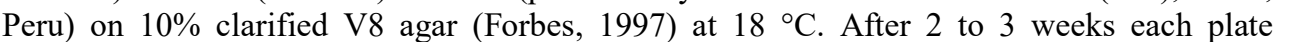

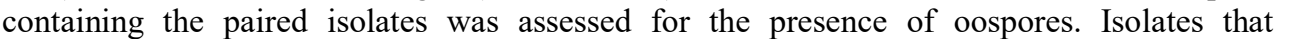

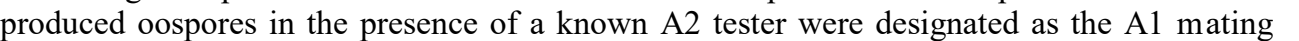
एणाए।

$\square$

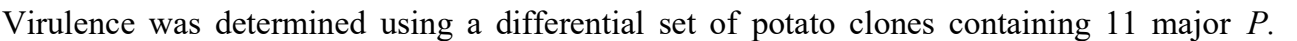

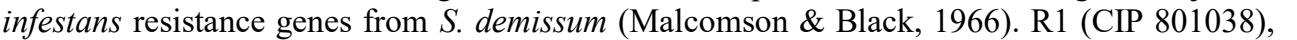

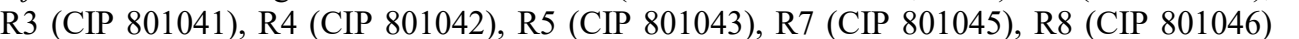

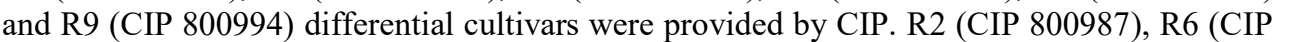

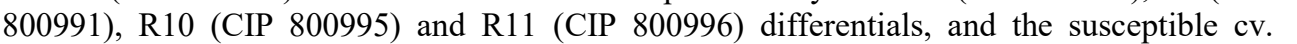

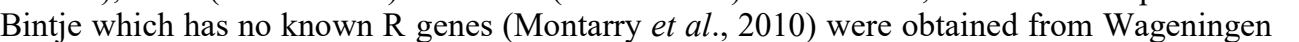

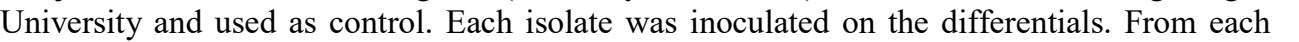




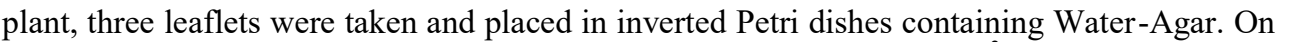

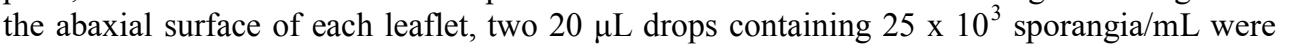

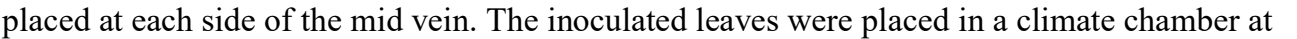

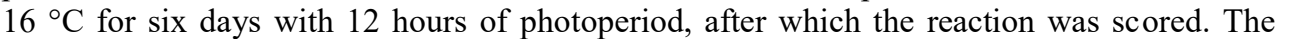

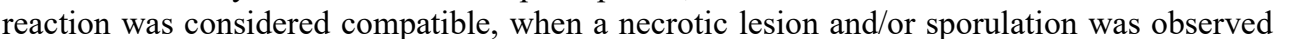

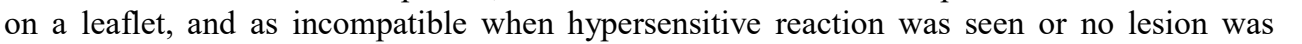
पाणमाण

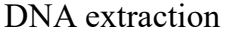

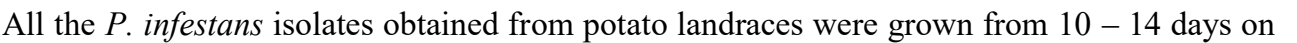

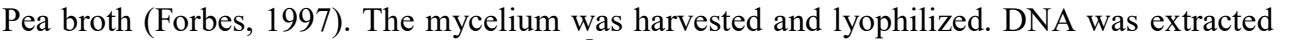

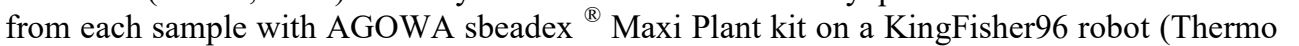

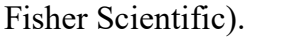

\section{$\square$}

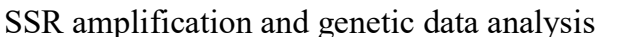

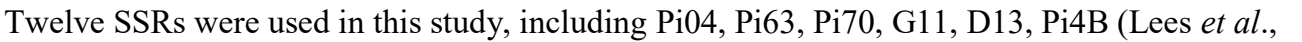

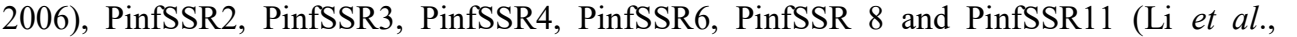

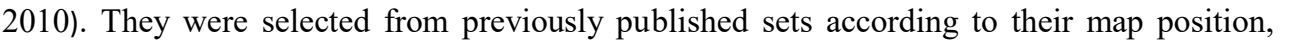

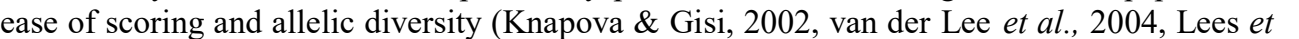

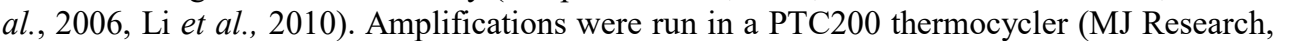

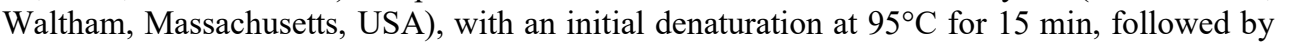

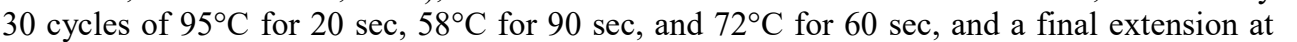

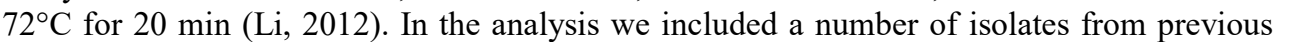

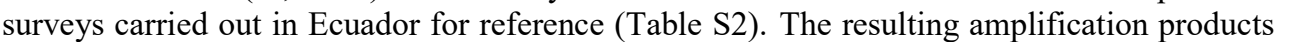

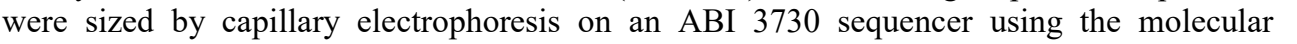

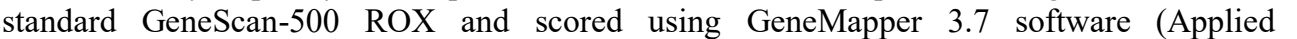

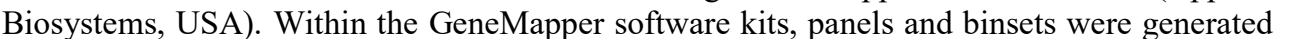

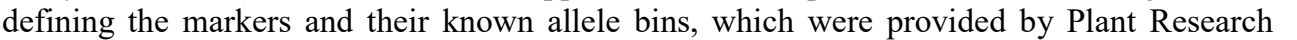

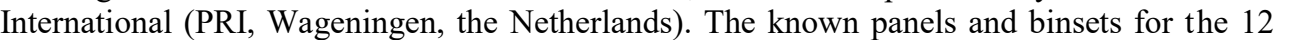

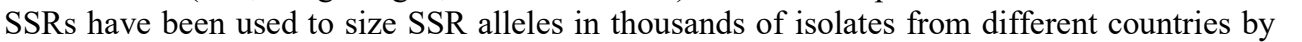

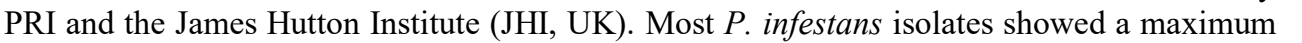

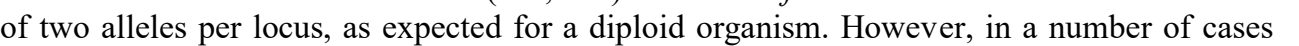

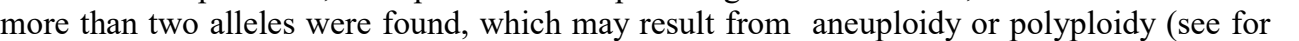

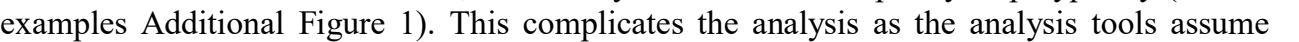

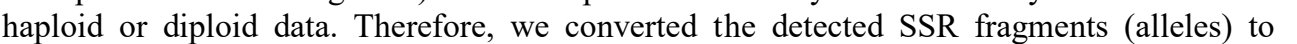

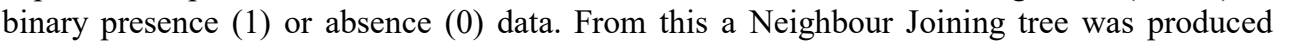

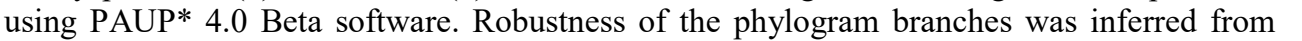

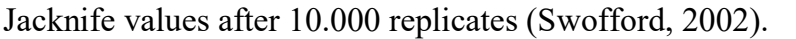

\section{$\square$}

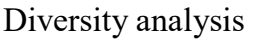

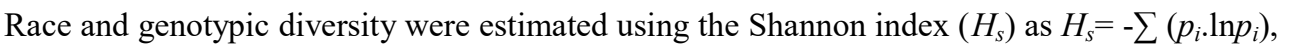

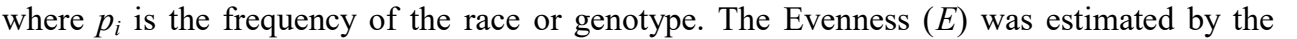

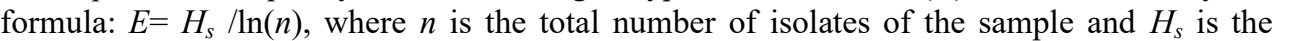

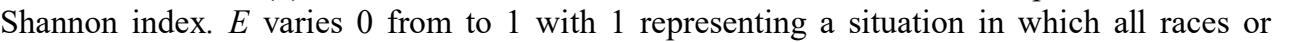

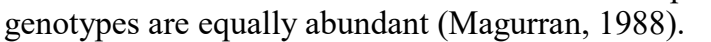




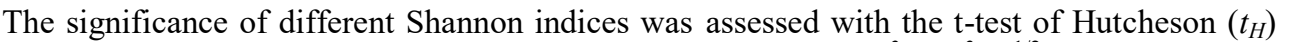

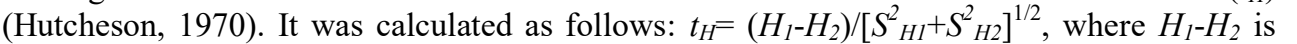

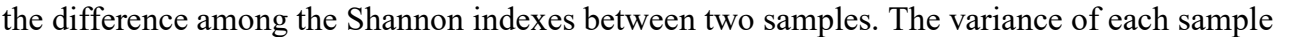

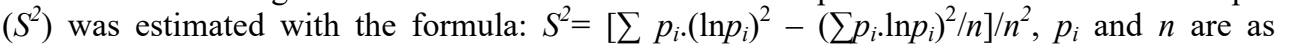

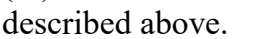

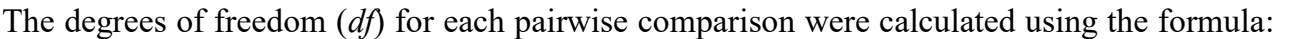

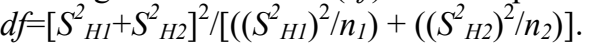

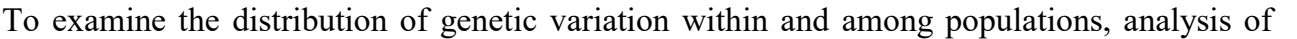

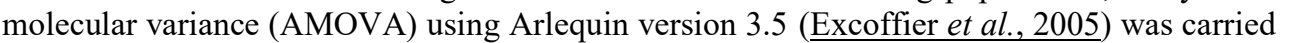

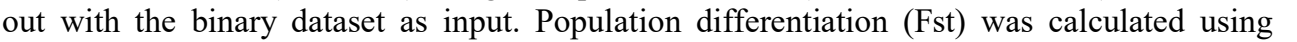

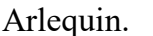

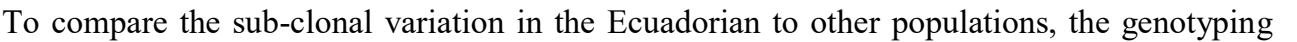

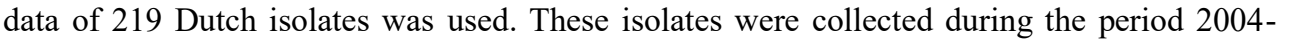

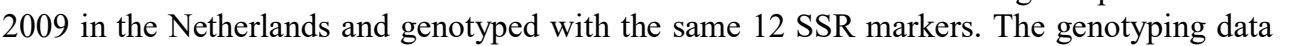

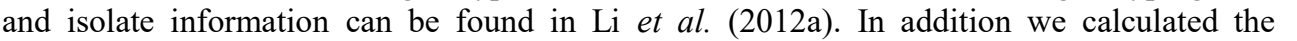

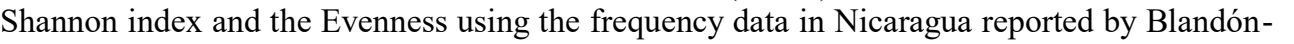

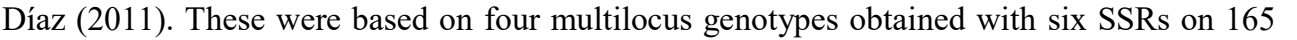

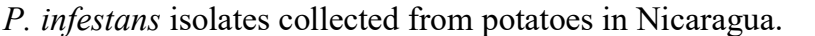

\section{Results}

$\square$

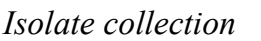

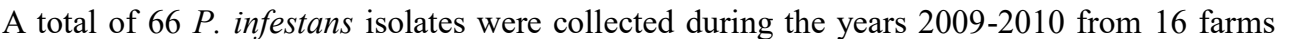

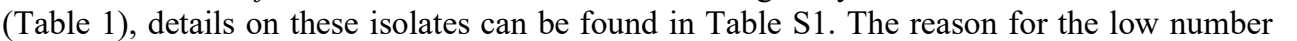

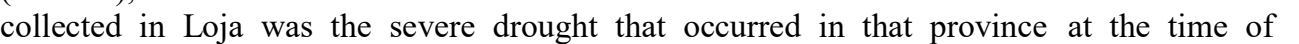

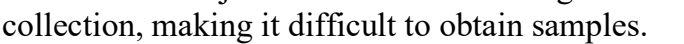

$\square$

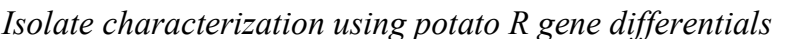

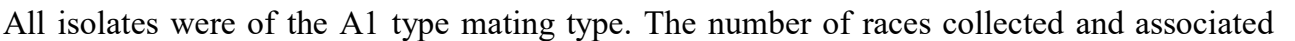

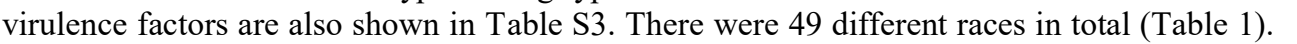

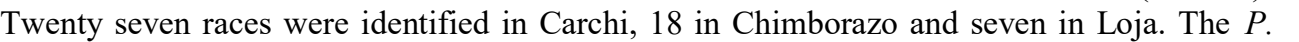

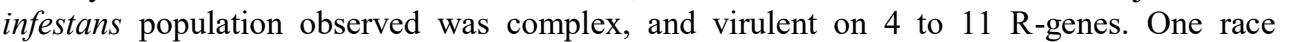

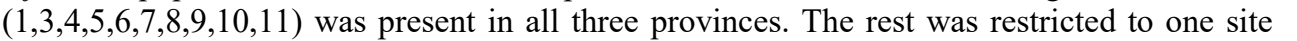

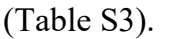

$\square$

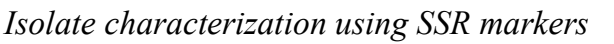

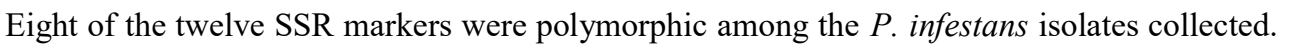

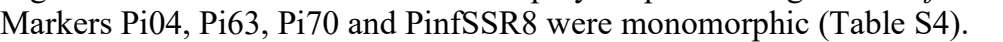




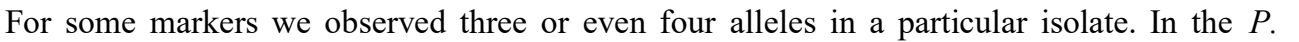
प

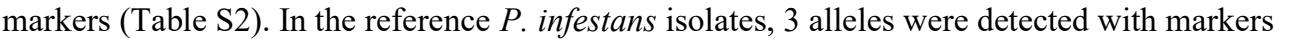

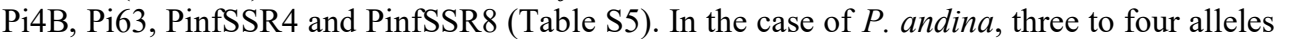

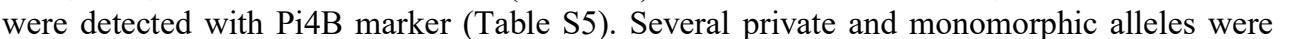

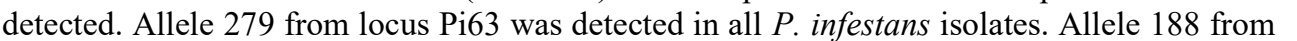

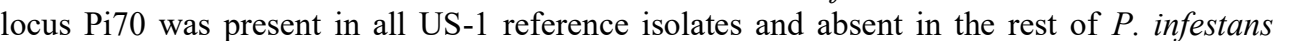
प

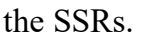

$\square$

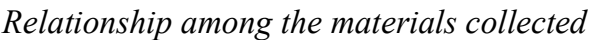

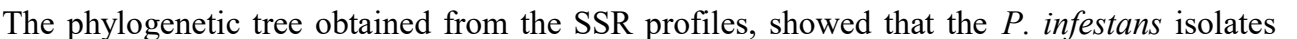

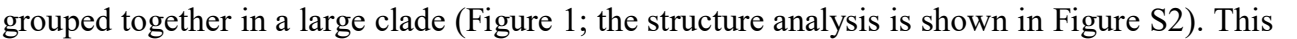

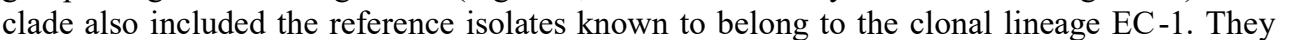

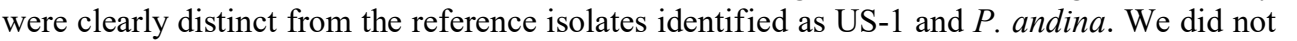

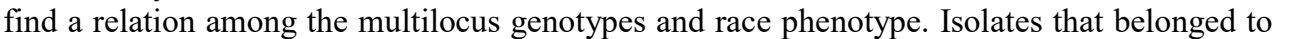

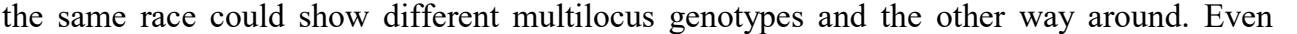
ए

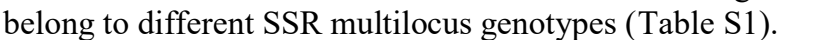

$\square$

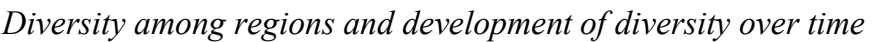

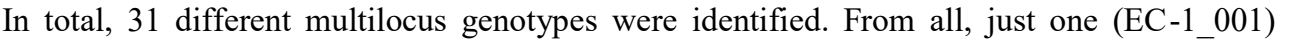

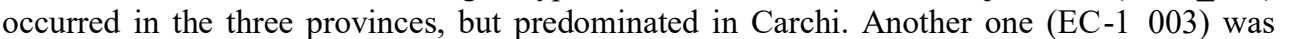

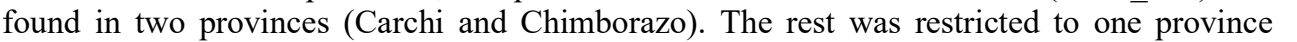

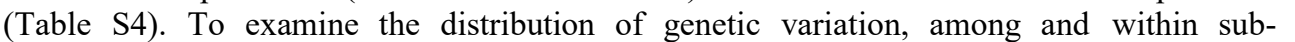

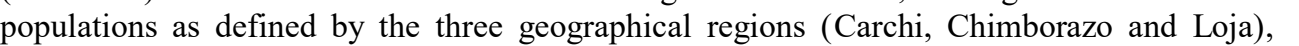

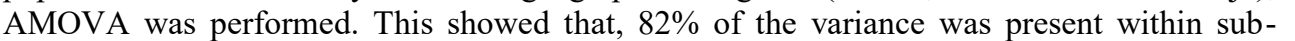

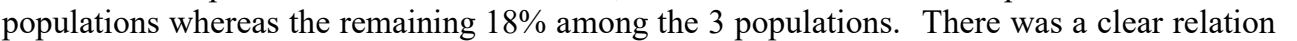

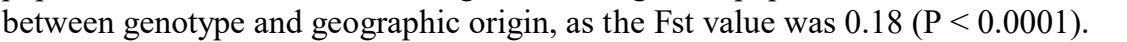

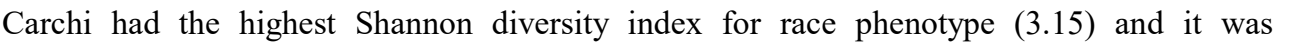

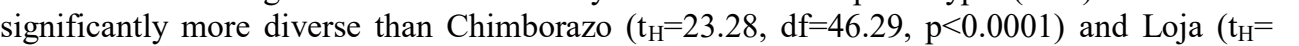

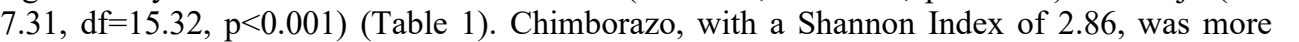

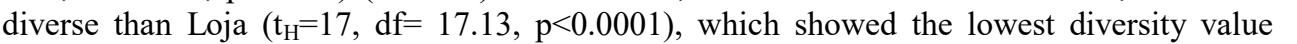

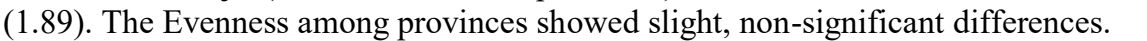

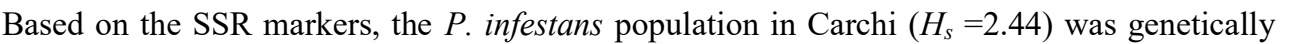

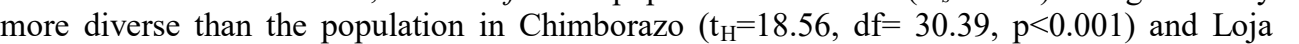

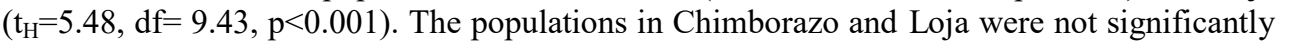

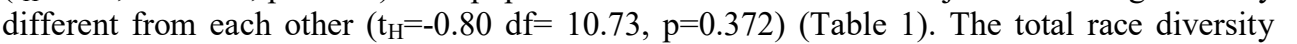

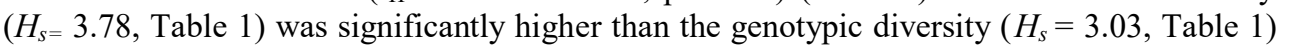

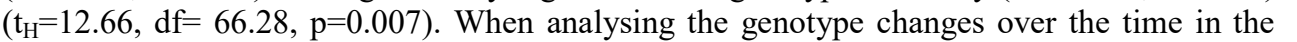

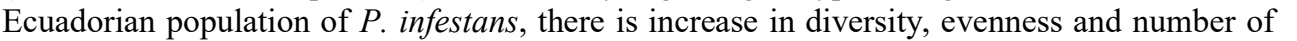

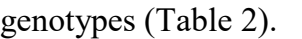

$\square$ 


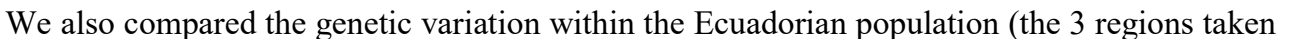

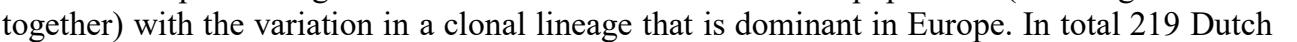
ए

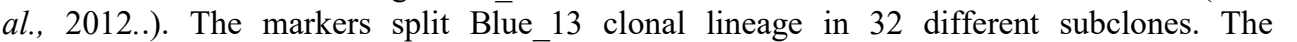

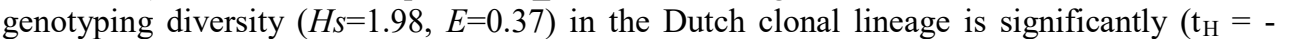

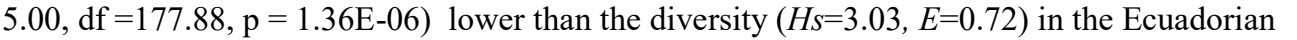

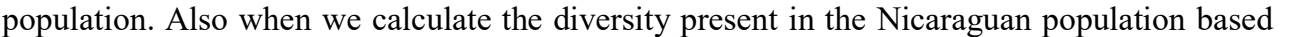

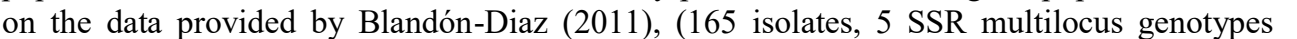

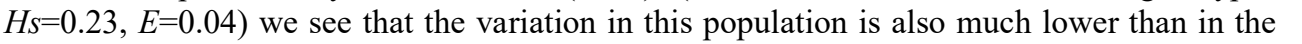

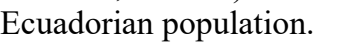

\section{Discussion}

$\square$

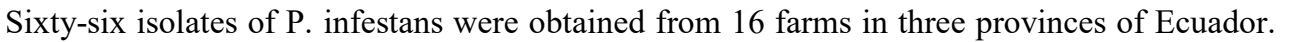

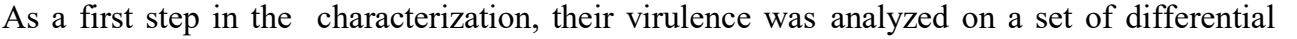

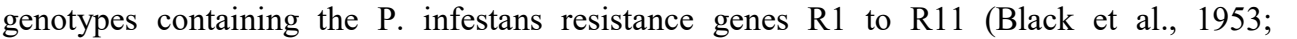

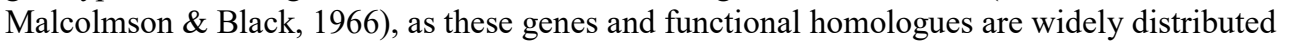

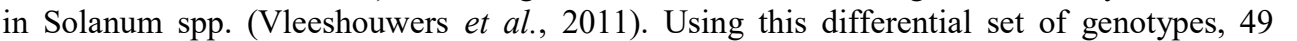

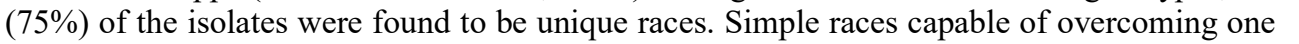

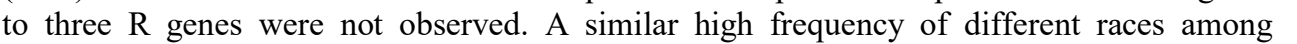

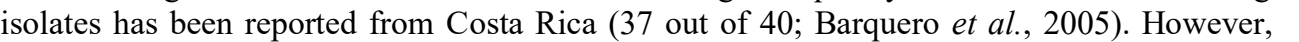

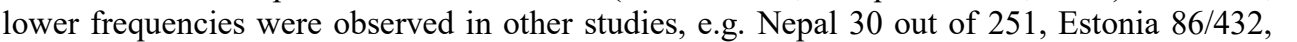

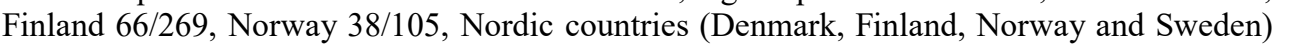

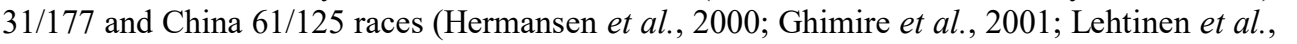

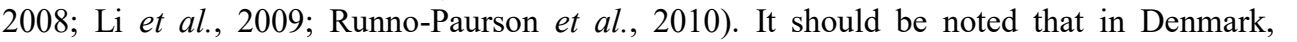

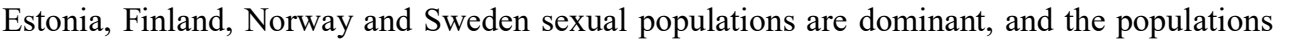

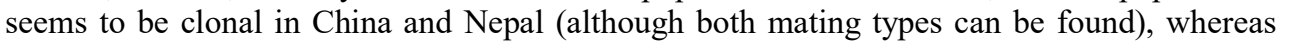

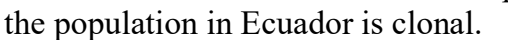

\section{$\square$}

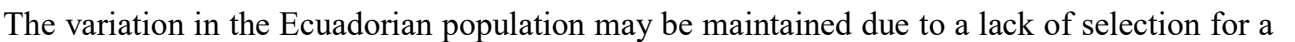

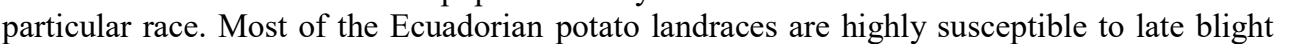

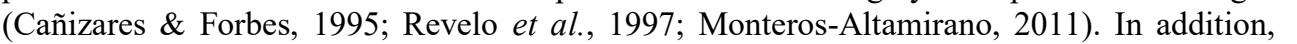

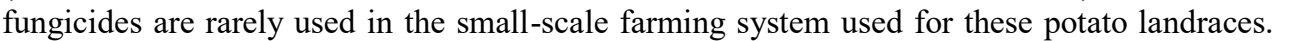

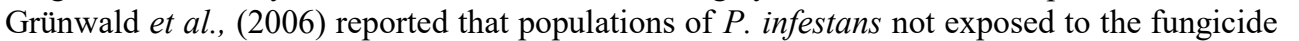

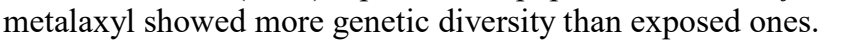

\section{$\square$}

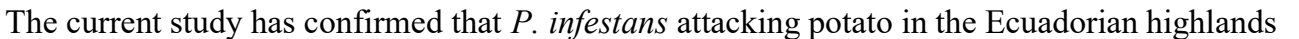

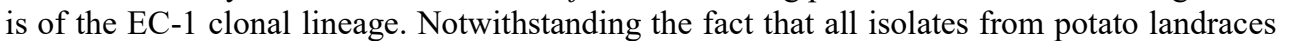

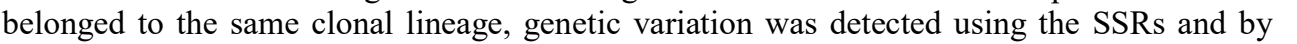

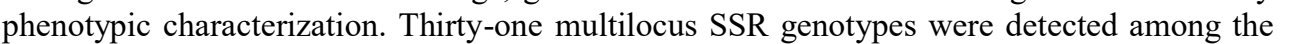

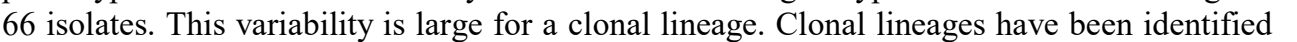

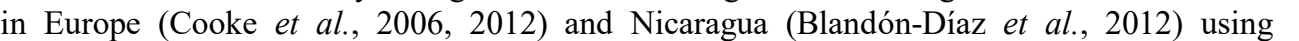

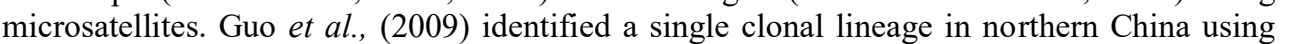




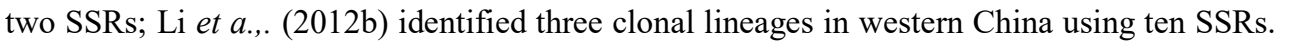

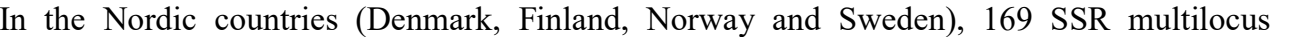

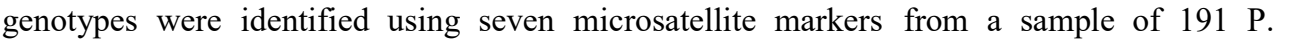

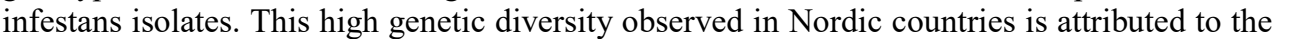

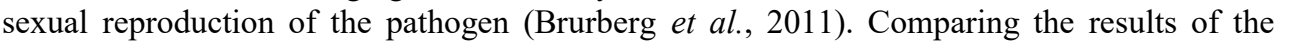

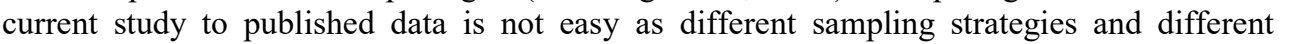

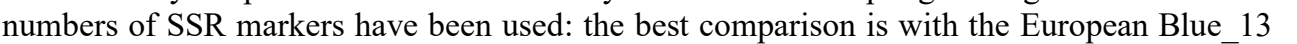
प

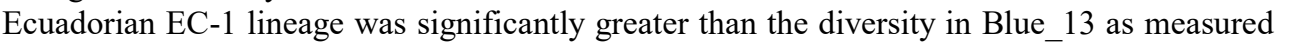

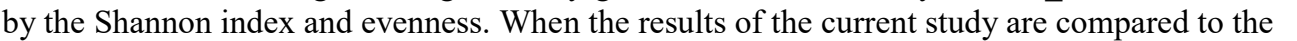

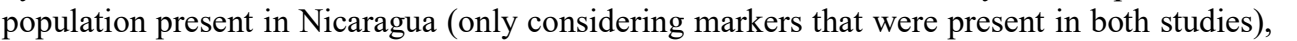

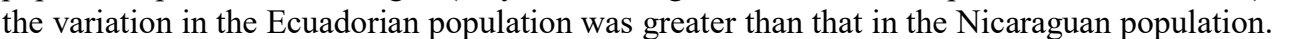

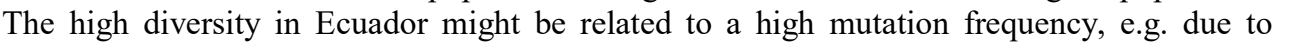
प ए।

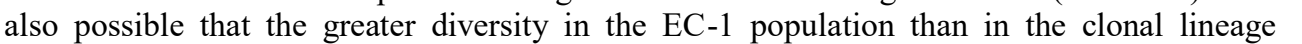

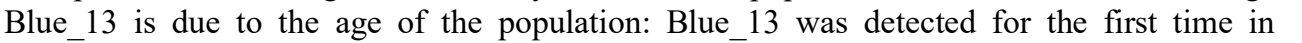

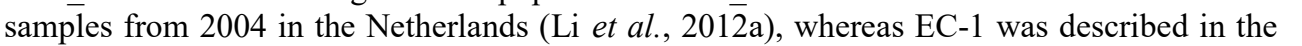

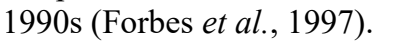

$\square$

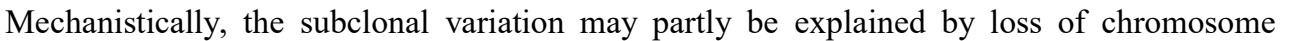

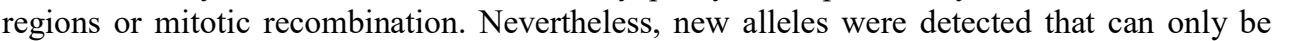

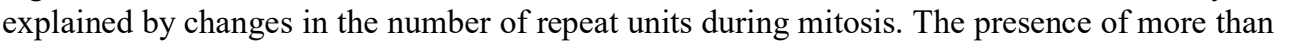

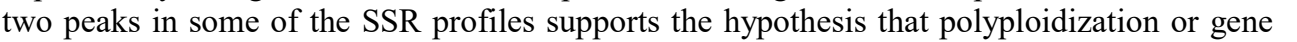

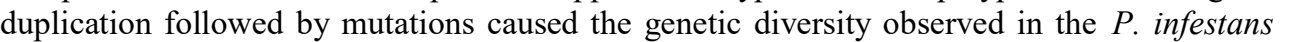

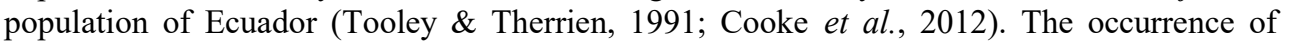

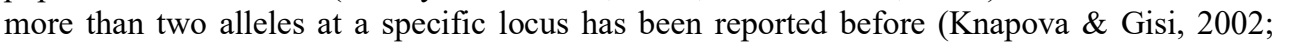

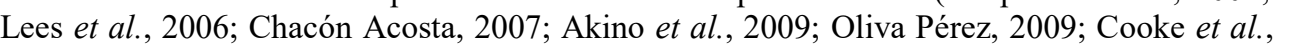

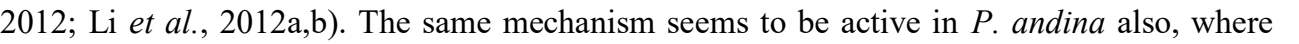

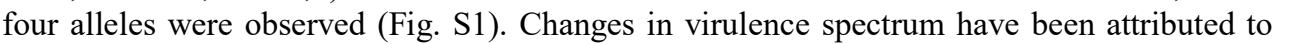

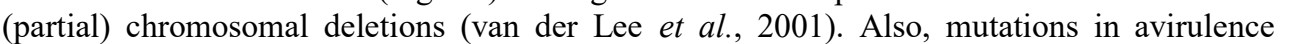

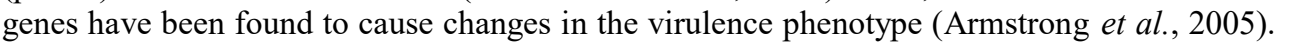

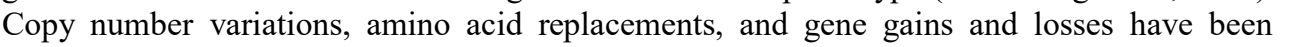

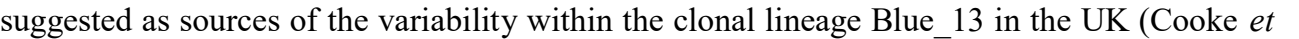

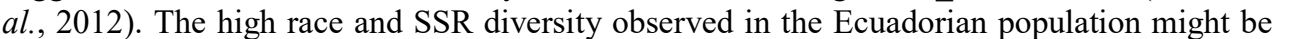

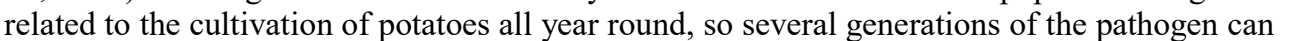

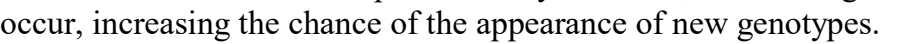

$\square$

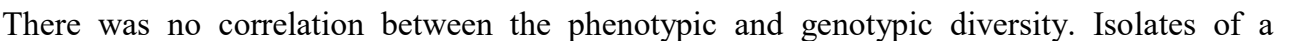

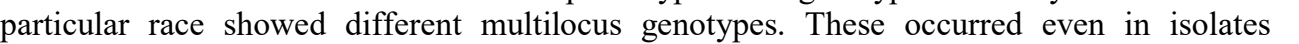

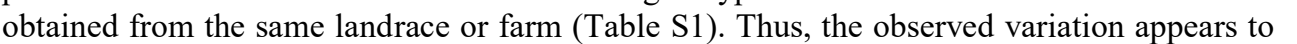

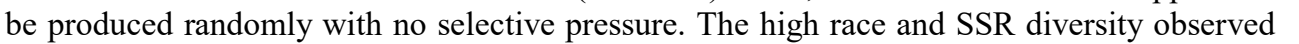

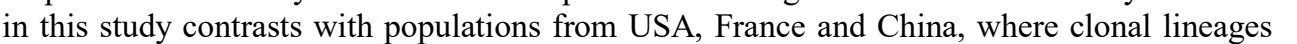

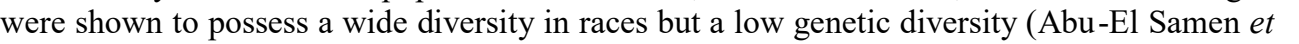

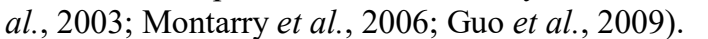

$\square$ 
The genetic diversity was highest in the Carchi province and significantly different from Chimborazo and Loja (Table 1). The FST analysis showed clear differentiation of the populations in the three regions and most of the variation was present within populations. This difference in diversity observed in Carchi could be due to the higher number of isolates and farms sampled. The highest evenness value was measured in Loja (0.93), although the number of samples was small (Table 1) and the value probably reflects under-sampling. The one genotype that occurred in all three provinces might have migrated through the Ecuadorian highlands, perhaps as a result of the exchange of landrace seeds among farmers (Monteros-Altamirano, 2011). Alternatively, this genotype may have arisen multiple times independently. The microsatellite analysis also showed some P. infestans lineage- and species-specific alleles. These may be used to distinguish clonal lineages (Akino et al., 2009). The SSR markers used in this study reflected the genetic diversity within the current P. infestans population in Ecuador: in future they may be used to monitor changes in the population and displacement of pathogen genotypes across the country. $\square$

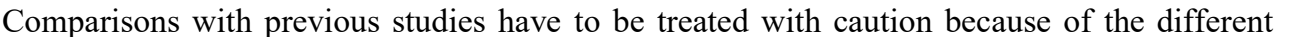

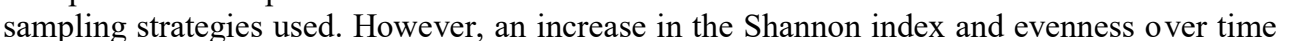

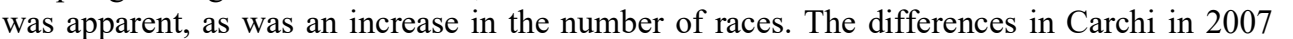

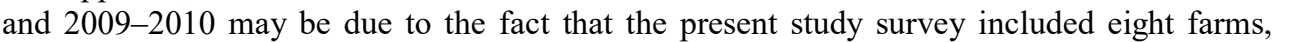

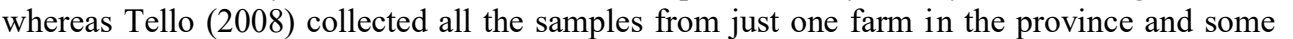

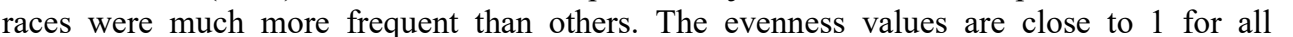

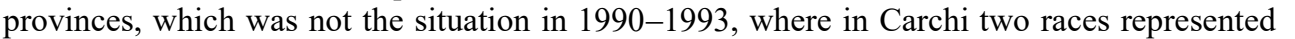

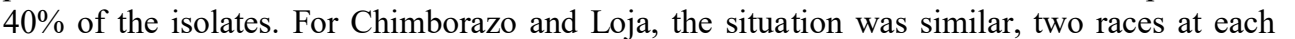

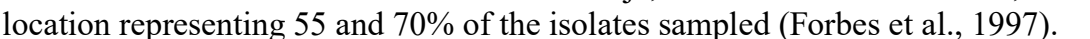

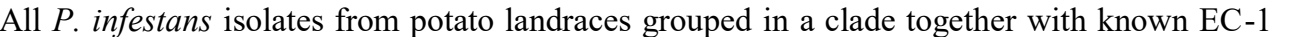

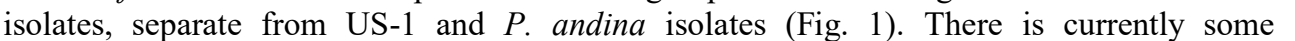

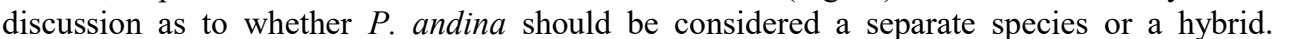

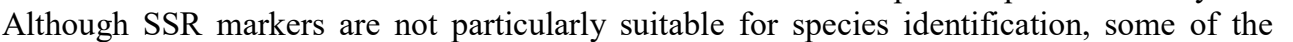

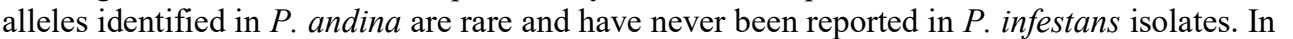

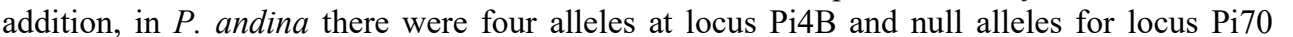

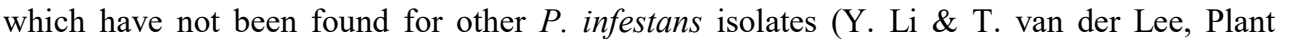

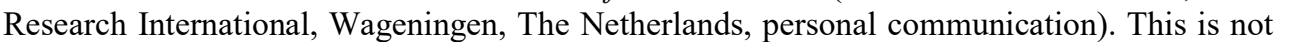

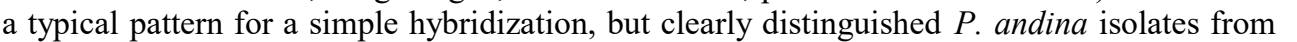

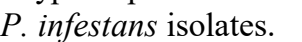

$\square$

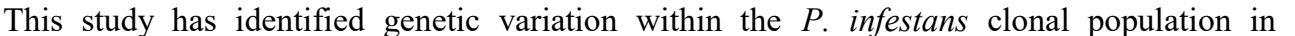

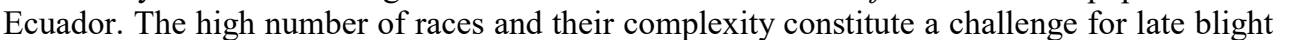

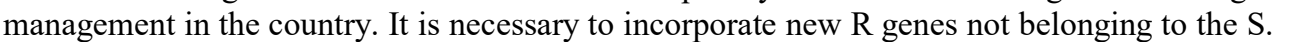

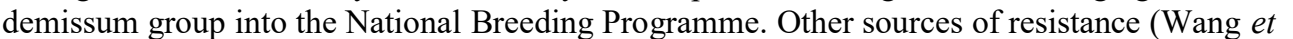

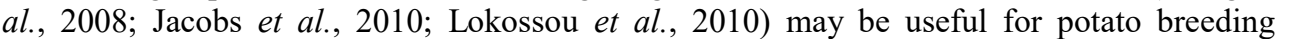

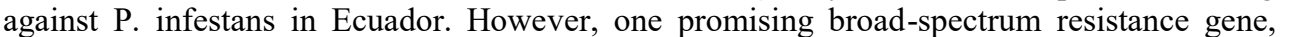

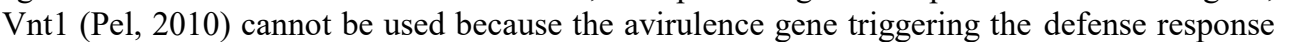

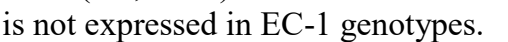




\section{Acknowledgements}

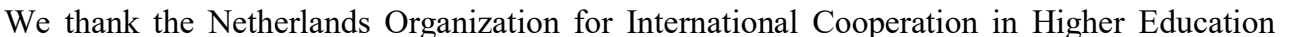

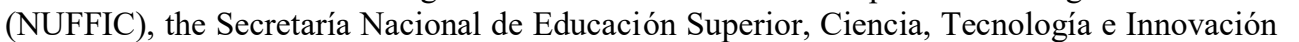

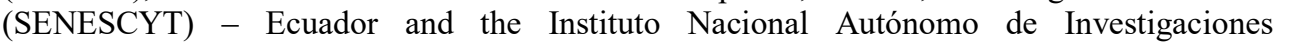

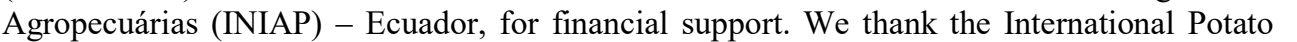

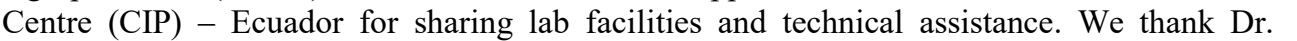

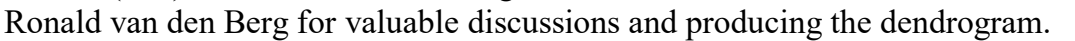

\section{Literature Cited}

$\square$

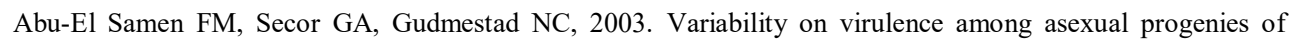

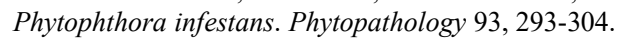

$\square$

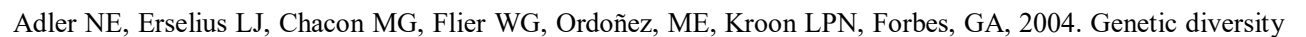

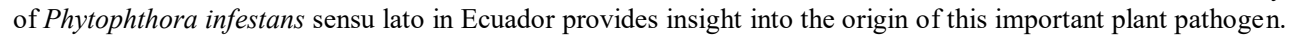

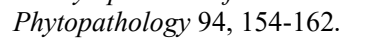

$\square$

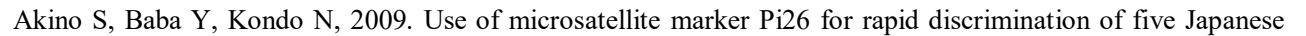

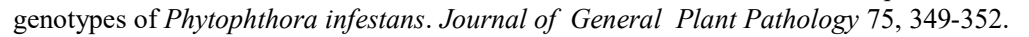
$\square$

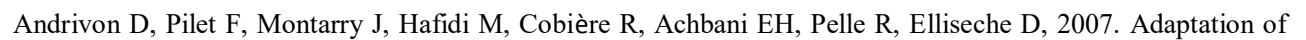

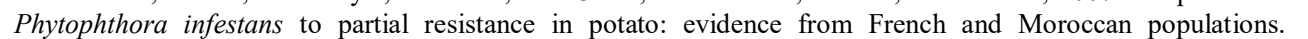

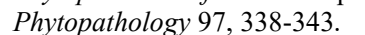

$$
\square
$$

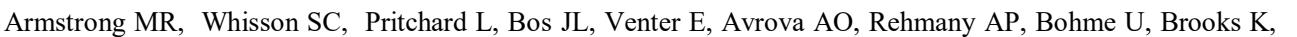

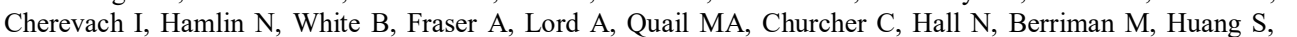

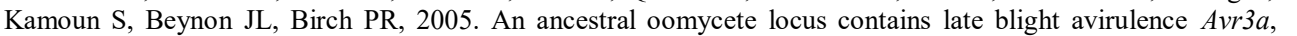

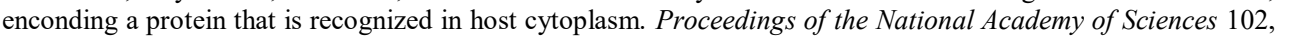
पालामाण

$\square$

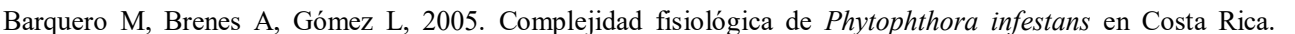

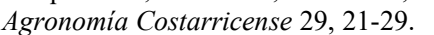
$\square$

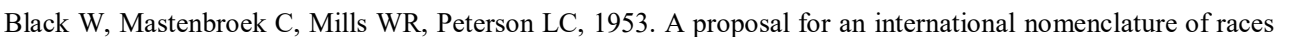

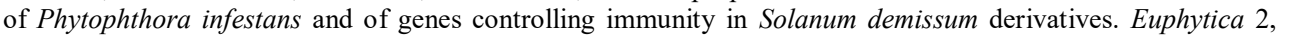
$\square+\square$

$\square$

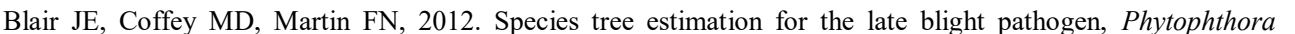

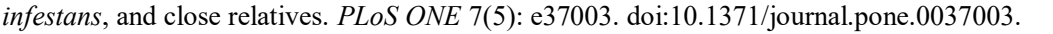
$\square$

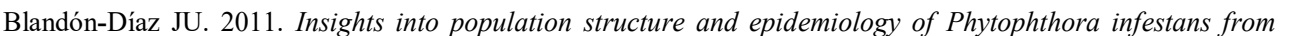

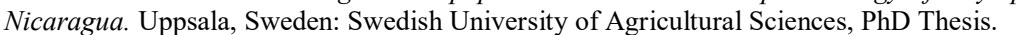
$\square$

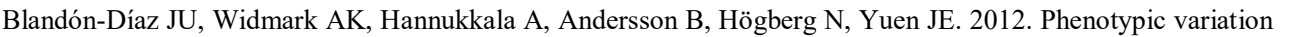

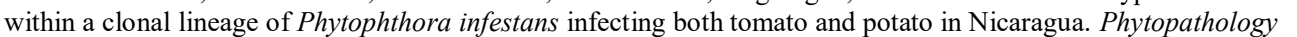

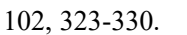

$\square$

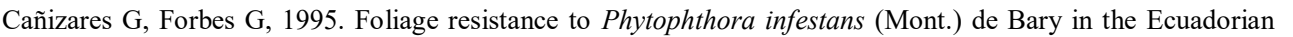

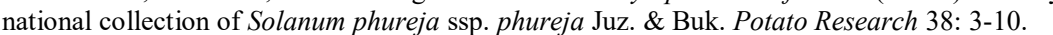
$\square$

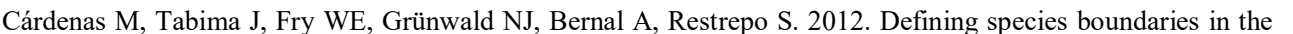

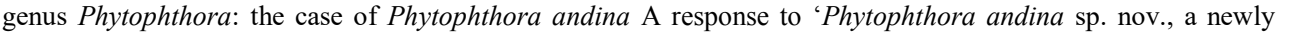

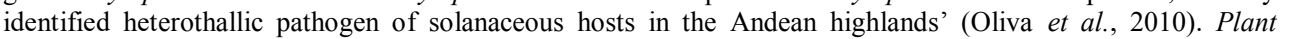

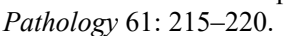


$\square$

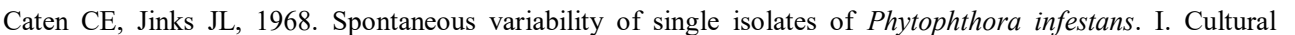

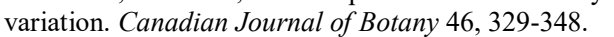

$\square$

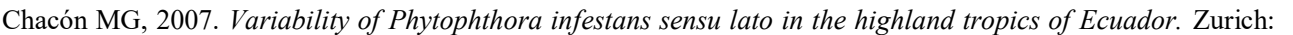

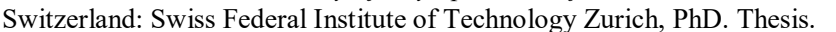

$\square$

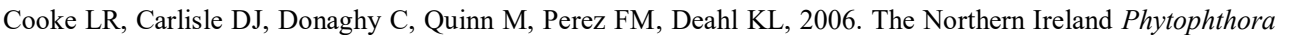

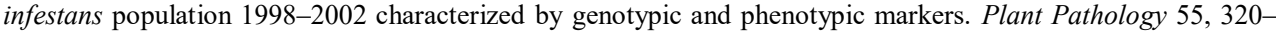
पालाप

$\square$

प

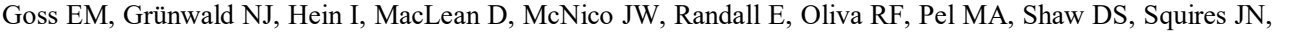

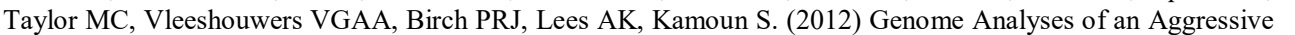

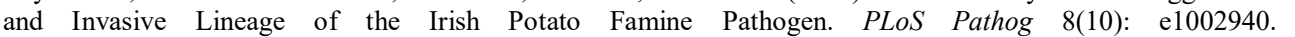

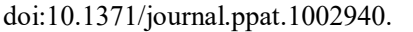

$\square$

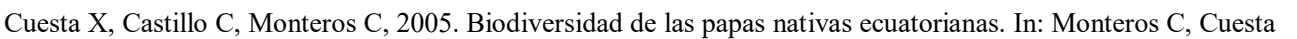

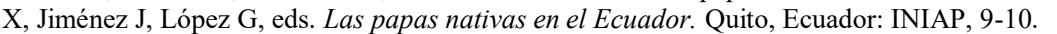

$\square$

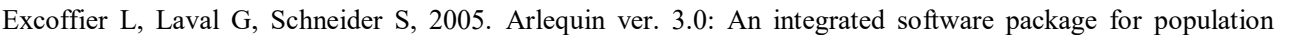

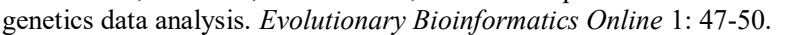

$\square$

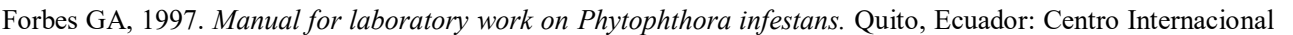
पाणापणाण

$\square$

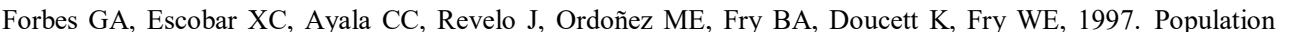

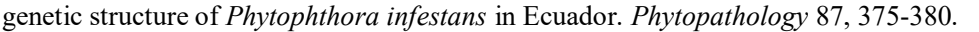

$\square$

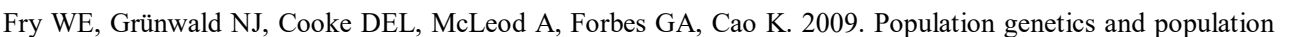

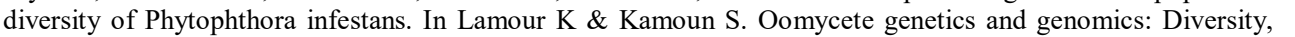

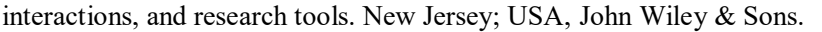
$\square$

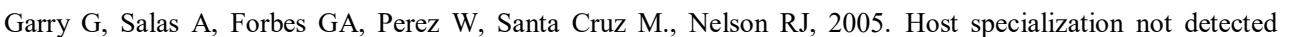

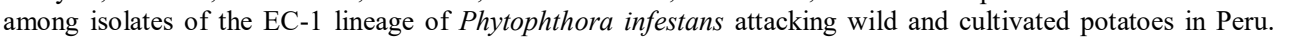

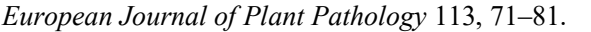
$\square$

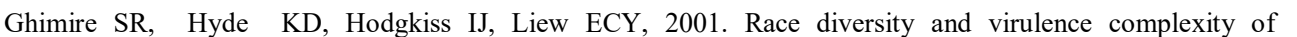

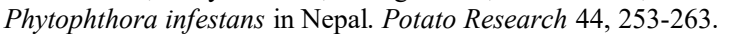

$\square$

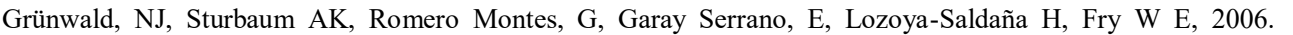

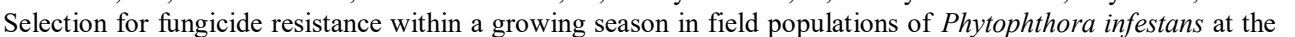

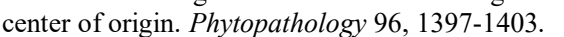

$\square$

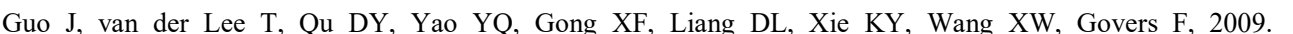

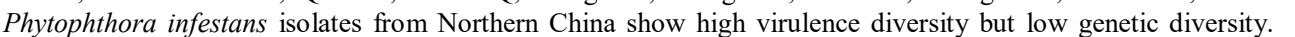

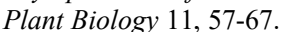

$\square$

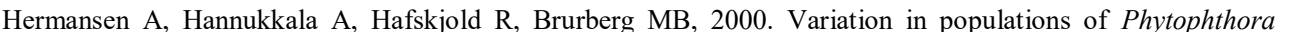

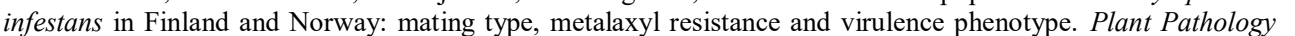
पाणाणणाण

$\square$

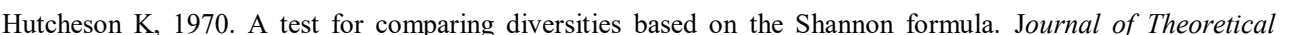

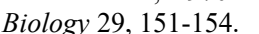

$\square$

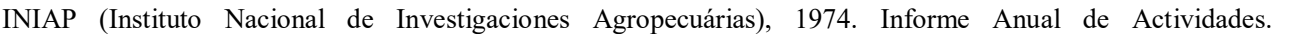

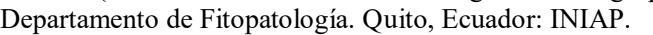

$\square$

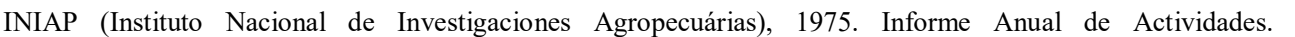

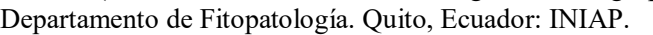


$\square$

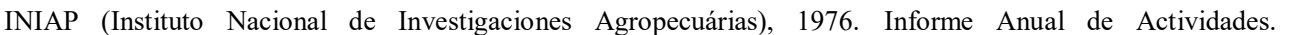

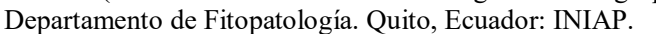

$\square$

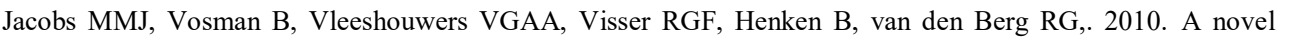

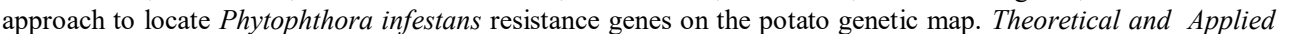

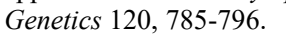

$\square$

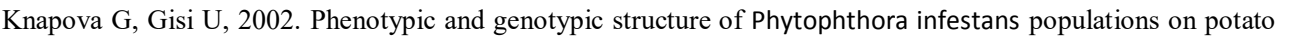

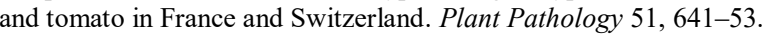

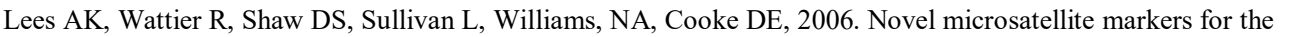

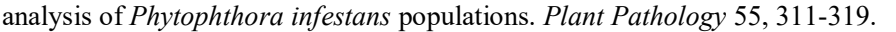

$\square$

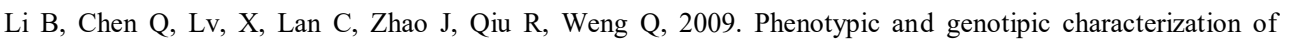

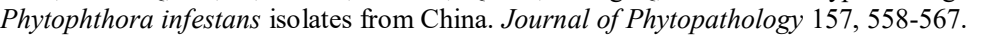
$\square$

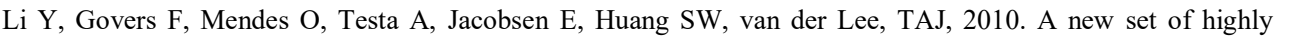

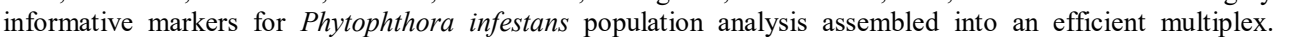

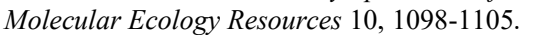

$\square$

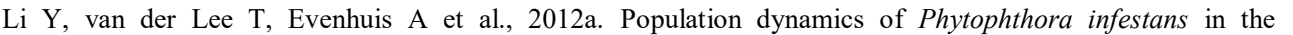

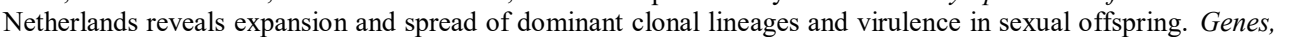

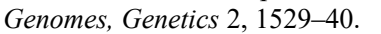

$\square$

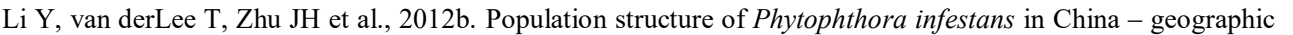

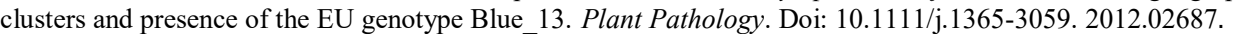

$\square$

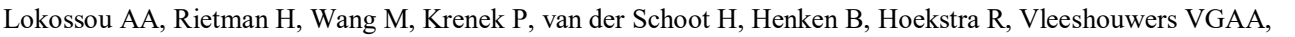

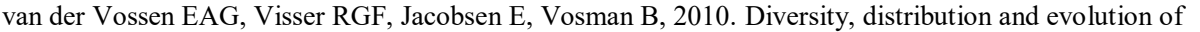

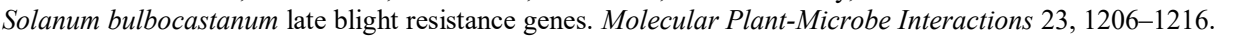

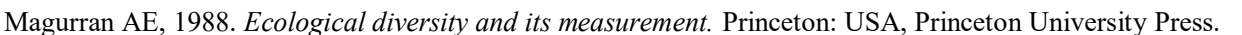

$\square$

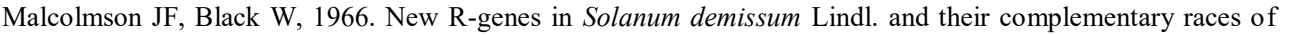

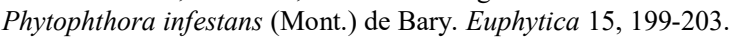

$\square$

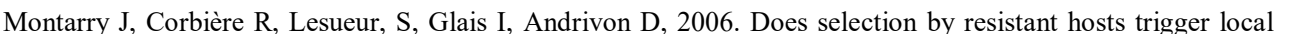

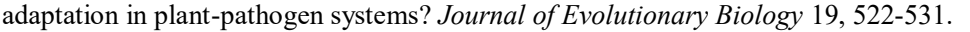
$\square$

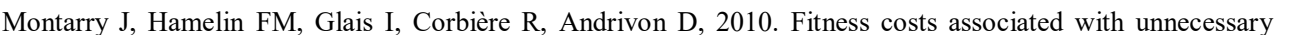

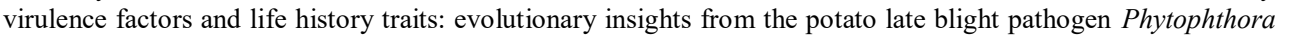

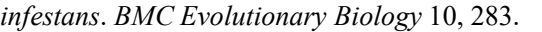

$\square$

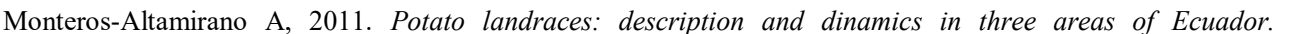

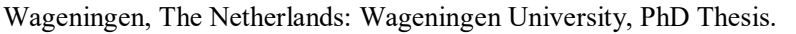

$\square$

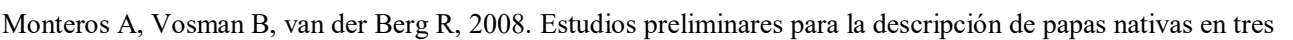

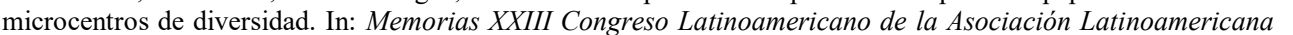

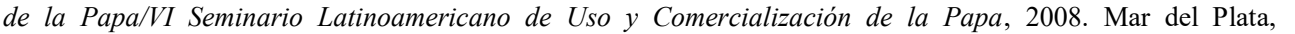

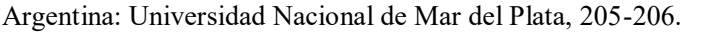
$\square$

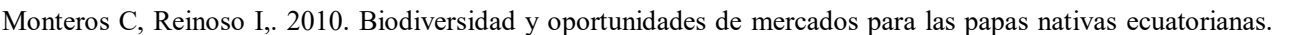

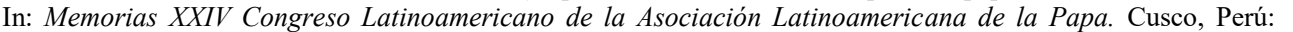
पापाणाणाप

$\square$

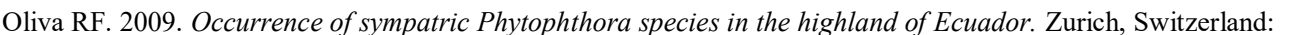

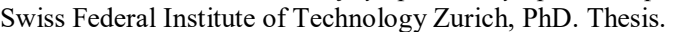

$\square$ 


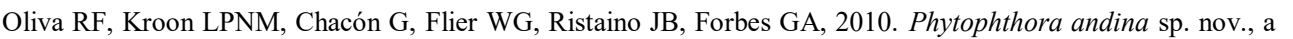

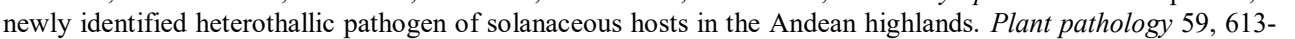
पाI

$\square$

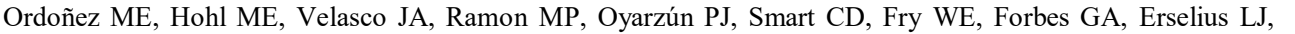

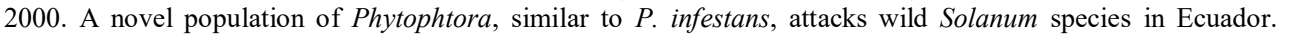

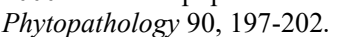

$\square$

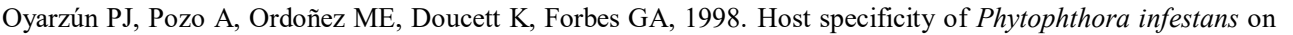

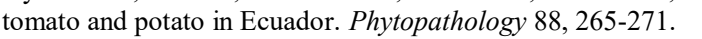

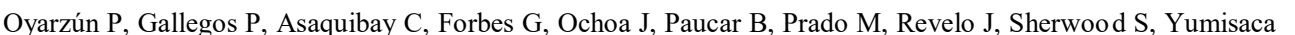

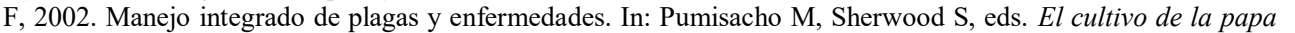

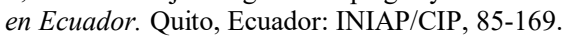

$\square$

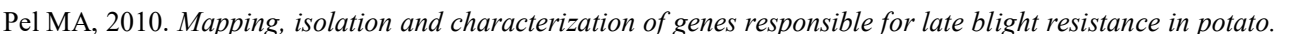

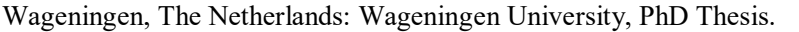

$\square$

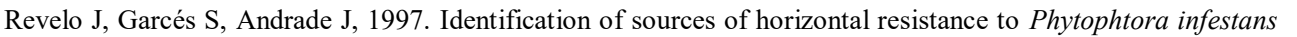

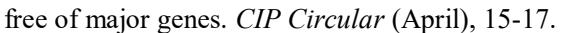

$$
\square
$$

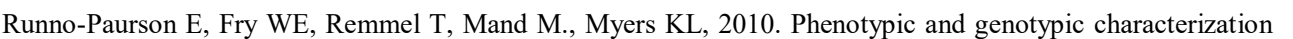

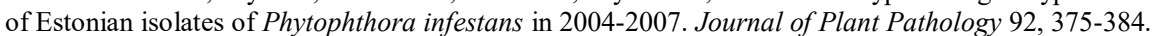
$\square$

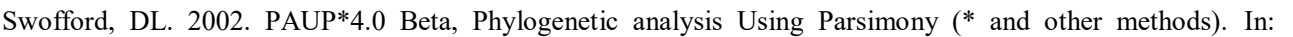

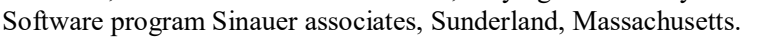
$\square$

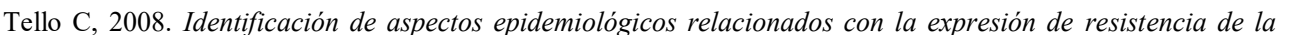

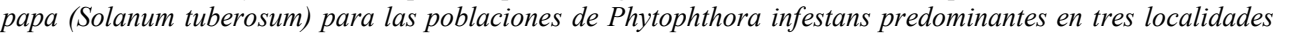

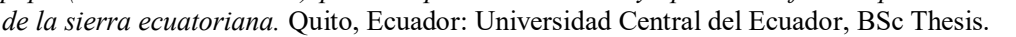
$\square$

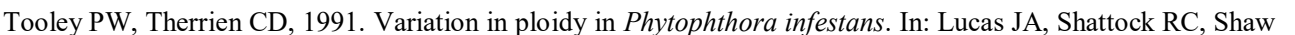

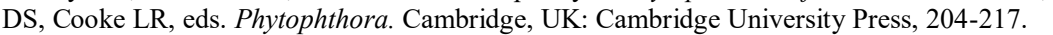
$\square$

van der Lee T, Testa A, van 't Klooster J, van der Berg

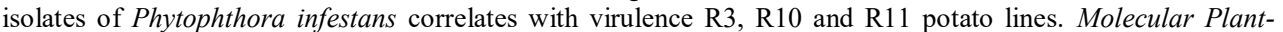

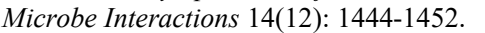

$\square$

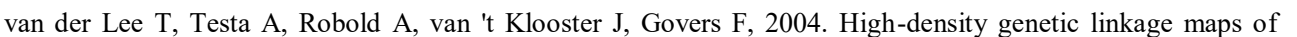

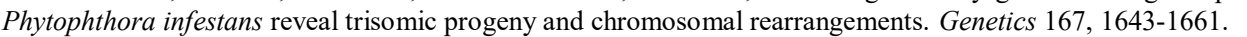
$\square$

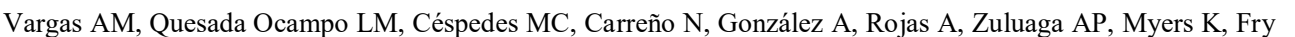

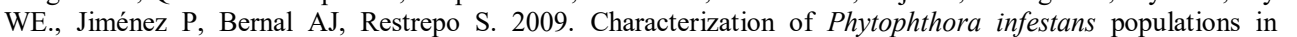

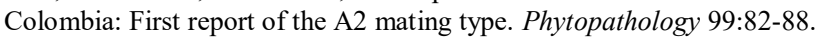
$\square$

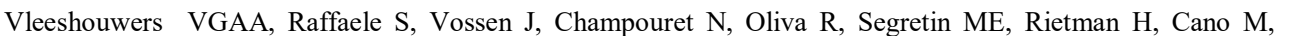

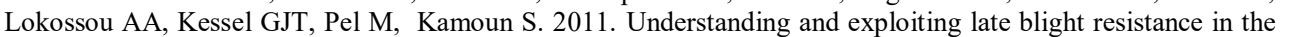

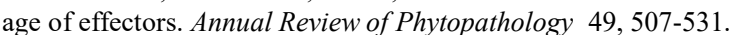

$\square$

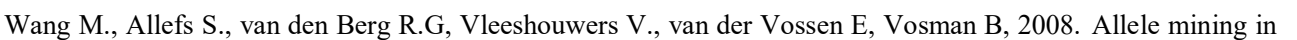

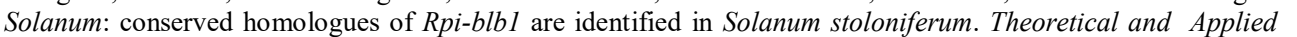

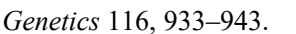

$\square$ 


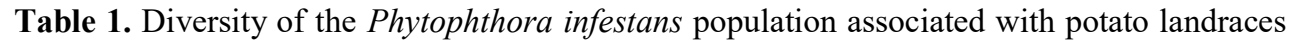

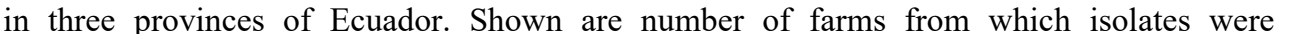

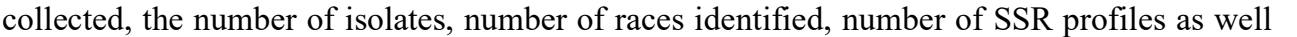

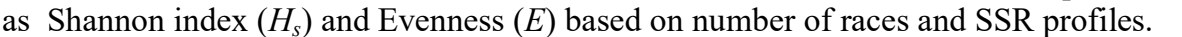

\begin{tabular}{|c|c|c|c|c|c|}
\hline 四 & 四 & $\square \square ण 10$ & 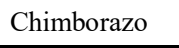 & 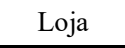 & $\square$ पाणाणा \\
\hline$\square$ & 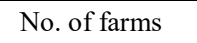 & $\square$ & $\square$ & $\square$ & $\square \square$ \\
\hline 四 & 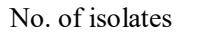 & $\square$ & $\square$ & $\square$ & $\square \square$ \\
\hline \multirow{3}{*}{ 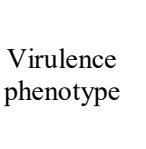 } & पणएा & $\square$ & $\square$ & $\square$ & $\square$ \\
\hline & $\square \square$ & पणाणाए & एणाய & एणाणाய & पणा \\
\hline & $\square$ & 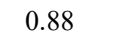 & $\square ण 1$ & $\square ण \square$ & पाए। \\
\hline \multirow{3}{*}{ 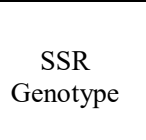 } & पாणாய & $\square \square$ & $\square$ & $\square$ & $\square$ \\
\hline & $\square_{\square} \square$ & पणाणा & एणाயण & पणाणए & एणए \\
\hline & $\mathrm{QP}$ & एणा मा म & एणाए & एणाए & एणा \\
\hline
\end{tabular}

Values followed by same letter within one line are not significantly different $(\alpha=0.05)$ according to the $t$

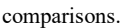

$\square$

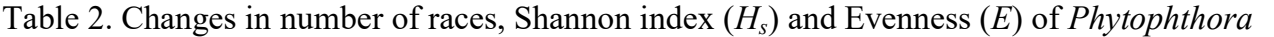

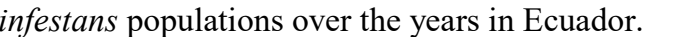

\begin{tabular}{|c|c|c|c|c|}
\hline \multirow{2}{*}{$\begin{array}{l}\square \\
\square \\
\square\end{array}$} & \multirow{2}{*}{$\square \square \square$} & \multicolumn{3}{|c|}{$\begin{array}{l}\square 101110 \\
\end{array}$} \\
\hline & & पवणाण & $\square \square \square \square\|\| \square$ & $\square \square \square$ \\
\hline$\square$ & $\square 111 \| 1 \square^{\square}$ & पाणा & 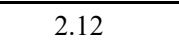 & पाणा \\
\hline$\square_{\square}$ & $\square \square^{\square}$ & पणा & प⿴囗十丁口卄 & पणाण \\
\hline$\square$ & $\square 11 \| 11^{\square}$ & पण口 & पणा & पणम \\
\hline$\square$ & $\square\|\|\|\|^{\square}$ & पणाए & पाएा & पणाए \\
\hline$\square$ & $\square \square^{\square}$ & $\square ण \square$ & पणापा & पणाण \\
\hline$\square$ & पालापाए & पणा & पणा & पण口 \\
\hline$\square$ & पामणाम & 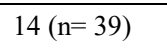 & 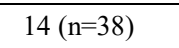 & पाण口णाण \\
\hline$\square \square \| \square$ & $\square \square^{\square}$ & एण口冋ாण & पणाप & पणाण \\
\hline$\square$ & $\square 11\|1\|^{\square}$ & 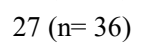 & 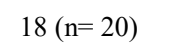 & पणाणाण \\
\hline 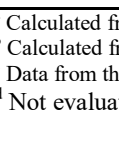 & 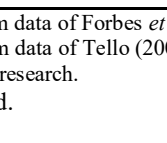 & & & \\
\hline
\end{tabular}




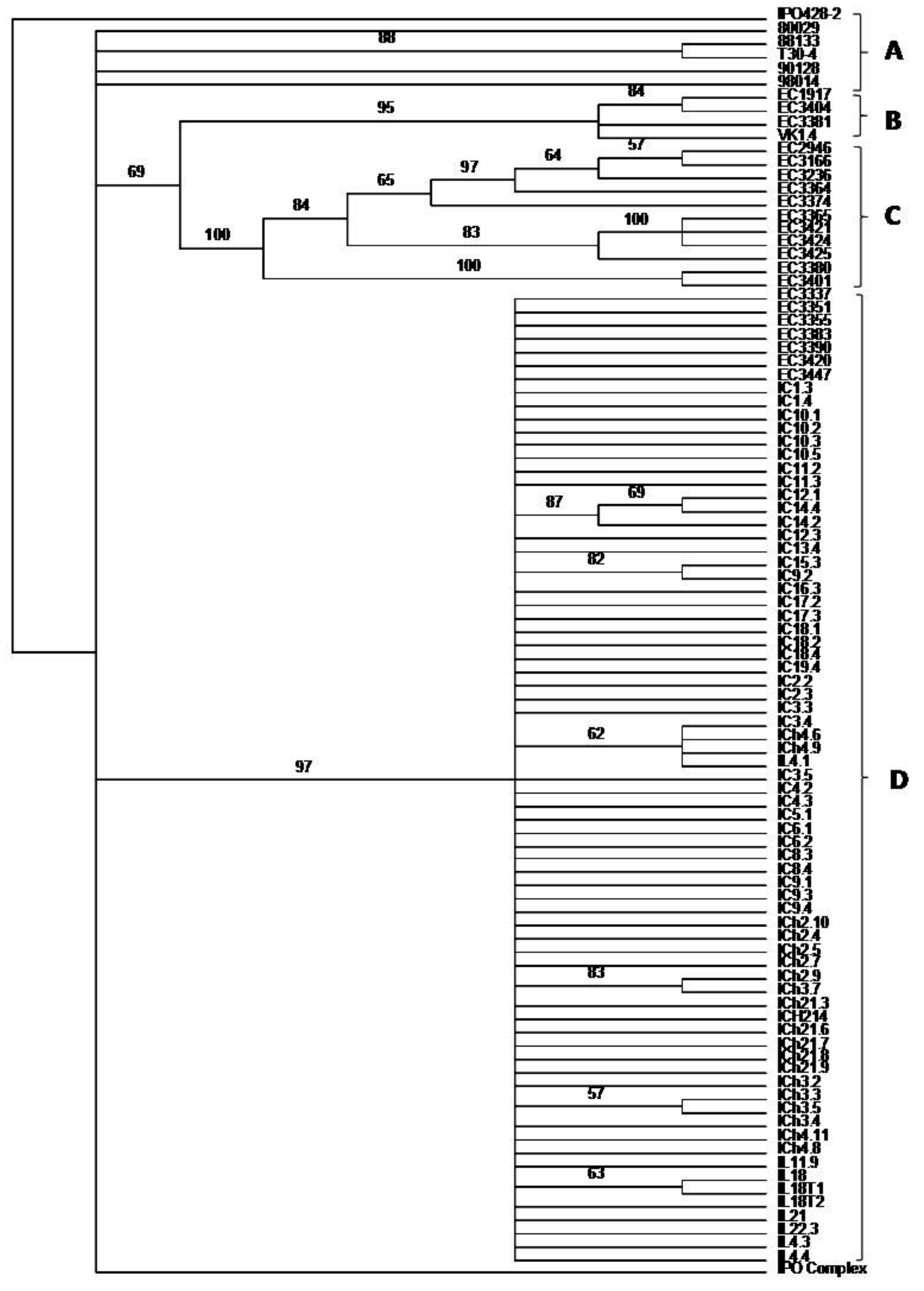

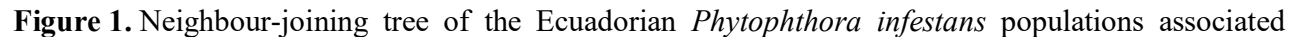

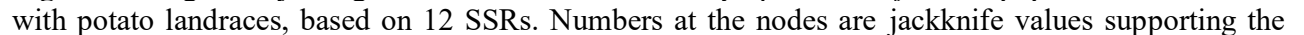

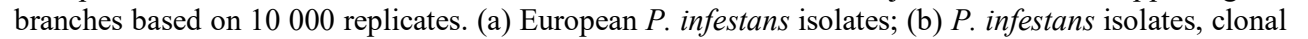

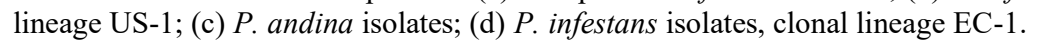




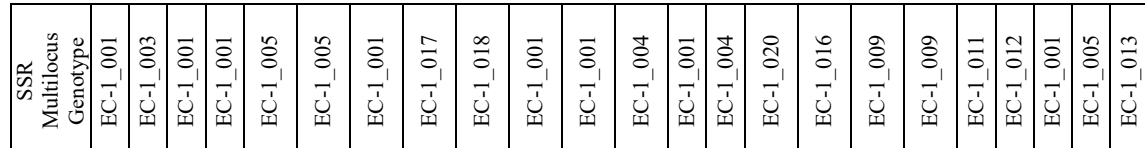

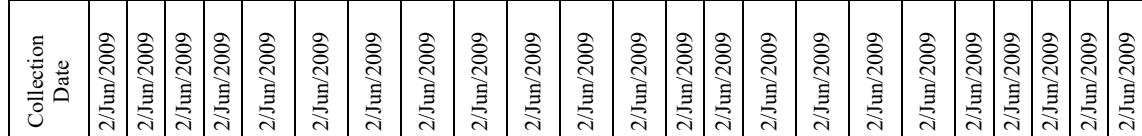

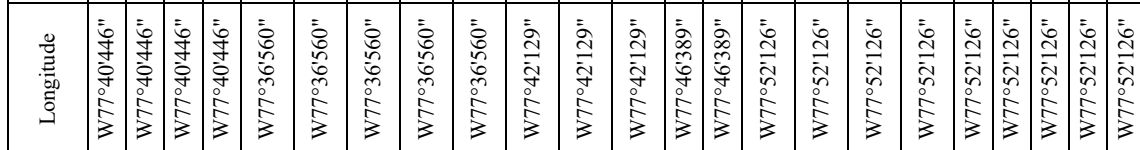

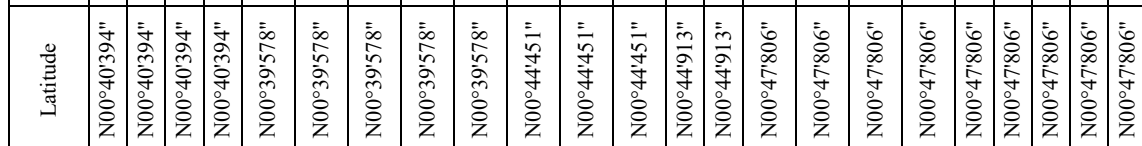

貝目

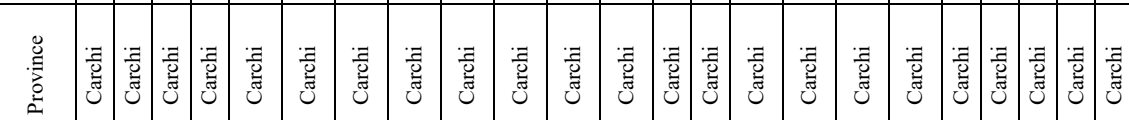

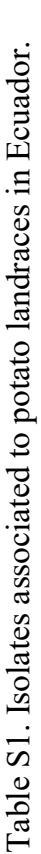

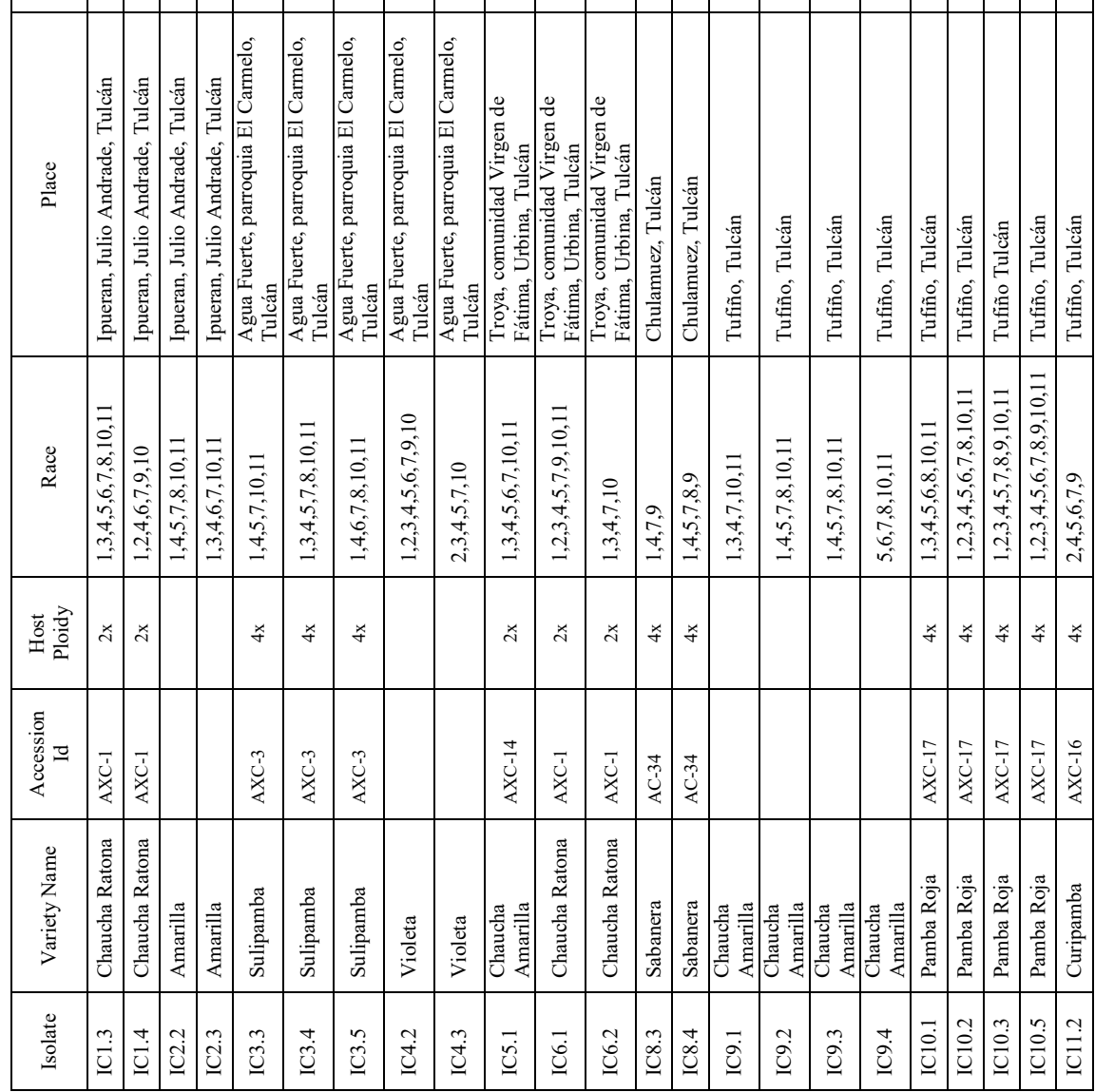




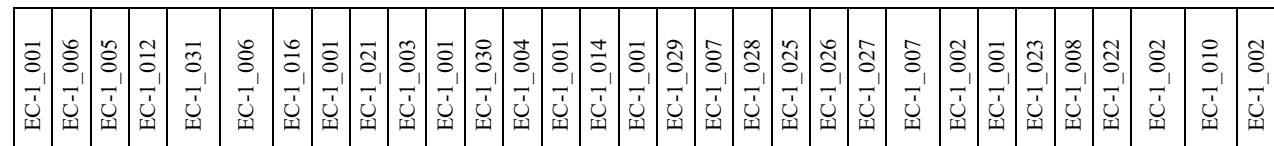

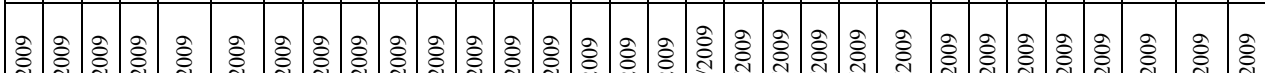

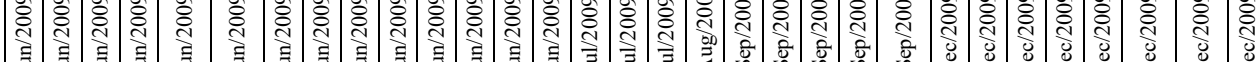

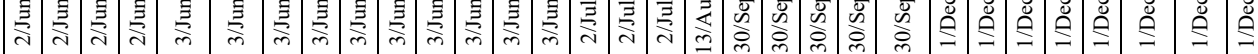

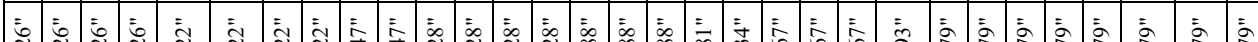

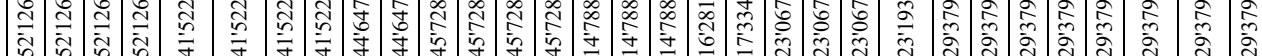

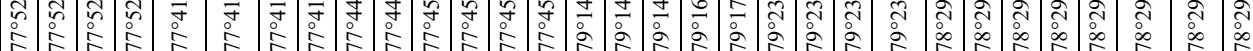

$\square \square \square \square(\square \quad \square \quad \square \square \square(\square \square \square \square \square \square \square \square \square \square \square \square \square(\square \square \square \square \square \square \square \square \square$

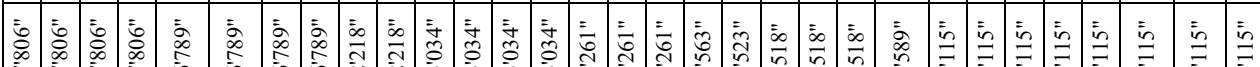

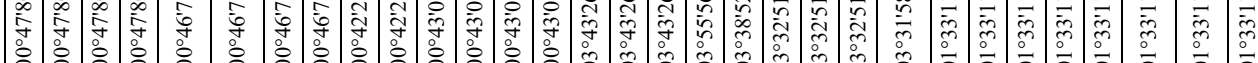

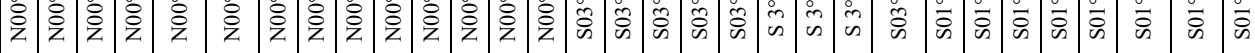

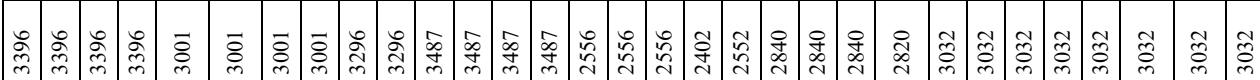

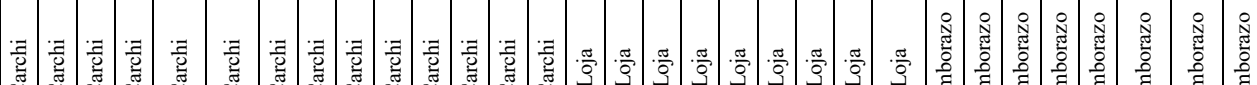

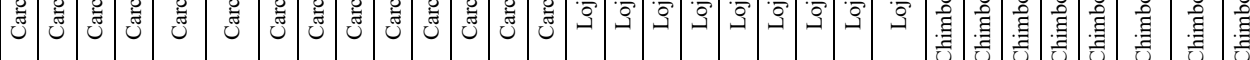

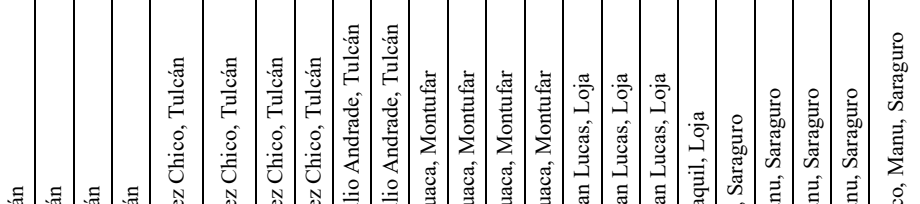

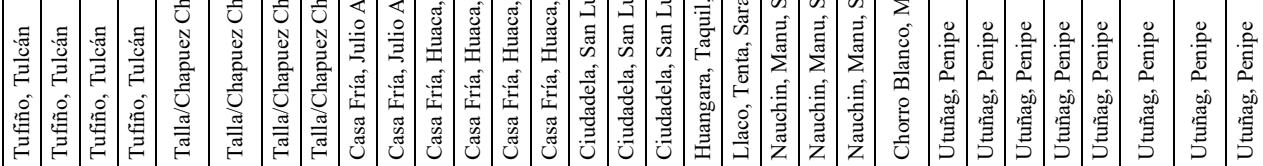

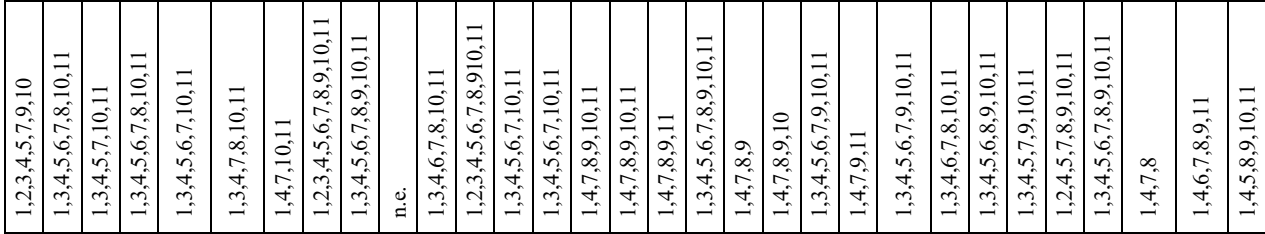

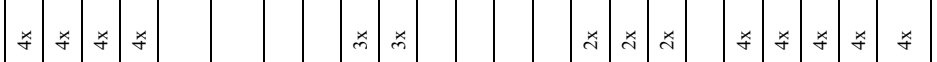

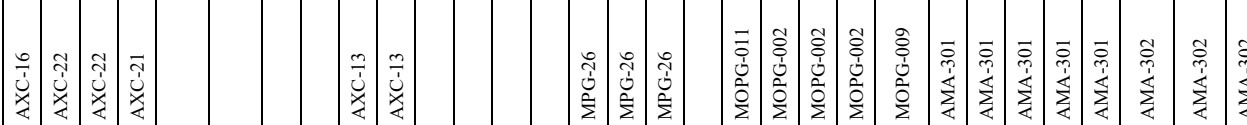

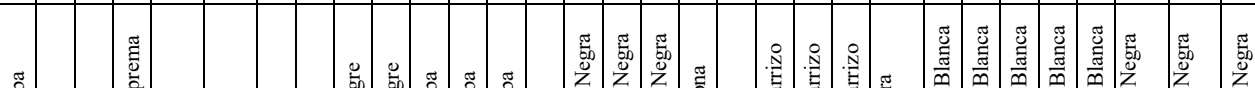

昷自

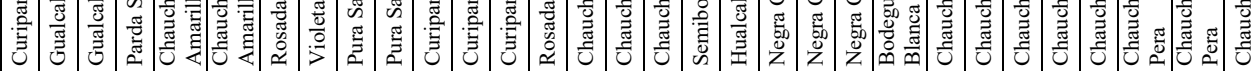

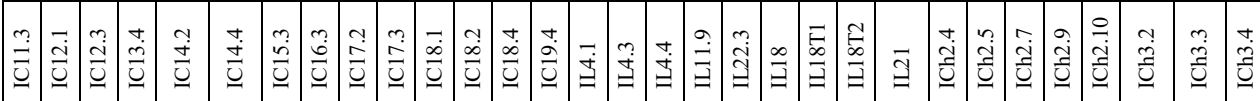




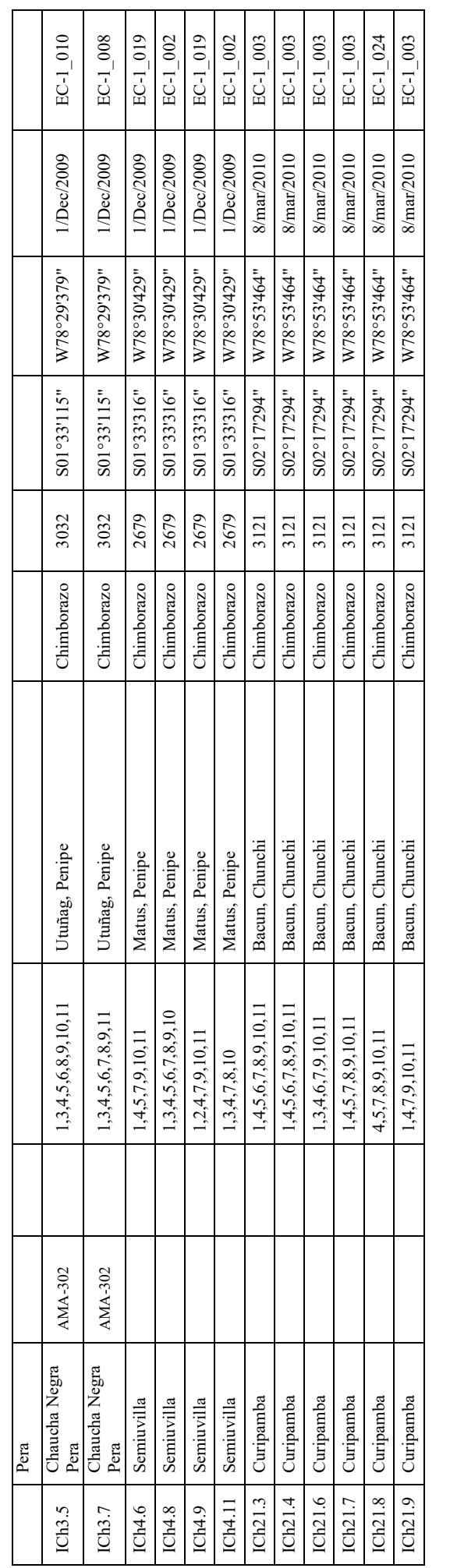




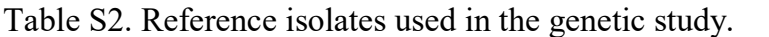

\begin{tabular}{|c|c|c|c|c|c|c|c|}
\hline पापाण & पषणा & 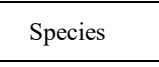 & $\begin{array}{l}\square \square \square \mid \\
\square \square \square \square \square\end{array}$ & 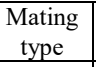 & 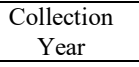 & पणापाप & $\square \square \mid त ा प$ \\
\hline$\square 11$ & पणापणाणमण & $\square$ & $\square$ & $\square$ & $\square \Pi \square$ & पाणाणाए & $\square \square 111 \square$ \\
\hline$\square 11$ & $\square$ & $\square$ & $\square$ & $\square$ & $\square 11$ & $\square$ & $\square \square \Pi \| \square$ \\
\hline$\square \Pi \square$ & पயாயாயா & पणाणा & $\square \square \square$ & $\square \square$ & $\square П \square$ & पणमाणाए & $\square \square 111 \square$ \\
\hline$\square 11$ & 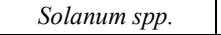 & $\square$ & $\square \square \square$ & $\square \square$ & $\square 11$ & $\square(1010111$ & $\square \square\|1\| \square$ \\
\hline$\square 11$ & पणा|णमाणम & $\square$ & $\square$ & $\square$ & $\square П \square$ & पएणाएप & $\square \square \Pi \Pi \square$ \\
\hline$\square 11$ & पाणा|णापाए & 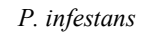 & $\square \square \square$ & पष & $\square 11$ & $\square \square|| \|||||$ & $\square \square\|1\| \square$ \\
\hline$\square 11$ & 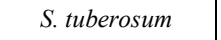 & 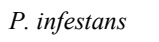 & $\square \square \square$ & $\square \square$ & $\square \prod$ & $\square \square\|1\| ा \| \square$ & $\square \square 111 \square$ \\
\hline$\square 11$ & एणाणामच & पणाणाए & $\square \square \square$ & $\square$ & $\square 11$ & 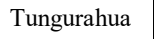 & $\square \square|1| \mathbb{\square}$ \\
\hline$\square 11$ & 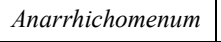 & पणामाण & $\square \square \square$ & $\square$ & $\square$ & $\square$ & $\square \square \Pi \| \square$ \\
\hline$\square 11$ & 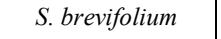 & $\square$ & $\square$ & $\square$ & $\square 111$ & $\square \square|||\||||$ & $\square \square|1| \square$ \\
\hline$\square 11$ & 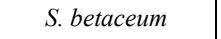 & पाणाणा & $\square \square \square$ & $\square$ & $\square 11$ & 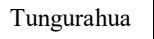 & $\square \square 111 \square$ \\
\hline$\square 11$ & 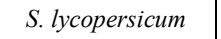 & 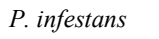 & $\square \square \square$ & $\square \square$ & $\square 11$ & $\square \square 11 \square ा ए \square$ & $\square \square \Pi 1 \square$ \\
\hline$\square 11$ & पणाणाणा & 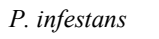 & $\square \square \square$ & $\square \square$ & $\square 1 \square$ & पणाणाए। & $\square \square 111 \square$ \\
\hline$\square 11$ & 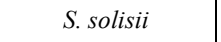 & 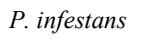 & $\square \square \square$ & $\square \square$ & $\square \Pi \square$ & $\square \square\|\| ा \|$ & $\square \square \| \Pi \square$ \\
\hline$\square П \square$ & एणाणापण & पालाण & $\square \square \square$ & $\square$ & $\square П$ & $\square \square\|\|\|ा\|$ & $\square \square \| \Pi \square$ \\
\hline$\square \amalg \square$ & 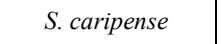 & पणमाणमाए & $\square \square \square$ & $\square \square$ & $\square \Pi \square$ & $\square \square 111 \| 11 \square$ & $\square \square 111 \square$ \\
\hline$\square 11$ & 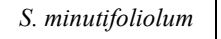 & $\square$ & $\square$ & $\square$ & $\square П \square$ & $\square \square|||||| \square$ & $\square \square 111 \square$ \\
\hline$\square П \square$ & पणापणाणाप & पाणाणा & $\square \square \square$ & $\square \square$ & $\square \prod$ & $\square \square\|\|\|\|$ & $\square \square 111 \square$ \\
\hline$\square П$ & 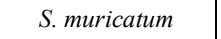 & पणाणाप & $\square \square \square$ & $\square \square$ & $\square П \square$ & $\square \square 11\|ा\|$ & $\square \square \| 1 \square$ \\
\hline$\square 11$ & पயாणாயாम & पाणाणा & $\square$ & $\square$ & $\square 11$ & $\square \square|1| \Pi|1|$ & $\square \square ा 11 \square$ \\
\hline$\square 11$ & पणाणणाए & पणाणमणाए & $\square \square \square$ & $\square \square$ & $\square 1 \square$ & पणणाणा & $\square \square 111 \square$ \\
\hline पवणा & 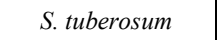 & पणमाणमाए & पवणा & $\square \square$ & $\square \Pi \square$ & $\square$ & पणमणया।य \\
\hline$\square 111$ & 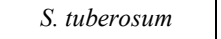 & पएणாயण1ए & $\square$ & $\square \square$ & $\square 11$ & $\square$ & 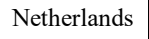 \\
\hline$\square \prod \square$ & 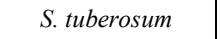 & पणमाणमाए & $\square$ & $\square \square$ & $\square П \square$ & $\square$ & 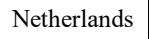 \\
\hline$\square 111$ & पाणम|ण|णम & 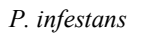 & $\square$ & $\square \square$ & $\square 1 \square$ & $\square$ & 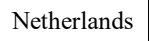 \\
\hline யणாणा & 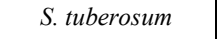 & पएणाणमाए & $\square$ & पम & $\square 11$ & $\square$ & 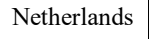 \\
\hline पपाण & 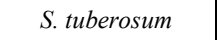 & पणमणणमाए & $\square$ & $\square \square$ & $\square П \square$ & $\square$ & पणमणणा।ण \\
\hline$\square П \square$ & 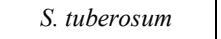 & पणमाणमाए & $\square$ & $\square \square$ & $\square 1 \square$ & $\square$ & 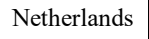 \\
\hline 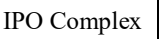 & 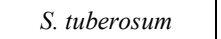 & पणमाणमाए & $\square$ & $\square \square$ & $\square \Pi \square$ & $\square$ & पणाणमा \\
\hline
\end{tabular}

$\square$ 


\begin{tabular}{|c|c|c|c|c|c|c|}
\hline \multirow{2}{*}{ पणा } & \multirow{2}{*}{ पपाए } & \multirow{2}{*}{ 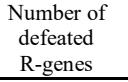 } & \multirow{2}{*}{ 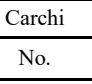 } & \multirow{2}{*}{ 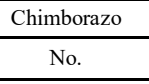 } & \multirow{2}{*}{$\begin{array}{l}\square \square \square \square \\
\square \square \square \square \\
\end{array}$} & \multirow{2}{*}{ 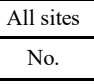 } \\
\hline & & & & & & \\
\hline$\square$ & पाणाणाप & $\square$ & $\square$ & $\square$ & $\square$ & $\square$ \\
\hline प & पणाणा & $\square$ & $\square$ & $\square$ & $\square$ & $\square$ \\
\hline 口 & पणामाणा & 口 & $\square$ & $\square$ & $\square$ & 口 \\
\hline 口 & பாயாण & $\square$ & $\square$ & $\square$ & $\square$ & 口 \\
\hline$\square$ & मणாயणम & $\square$ & $\square$ & $\square$ & ए & $\square$ \\
\hline ए & पमापाए & 口 & $\square$ & $\square$ & 口 & 口 \\
\hline ए & पमामाणाए & $\square$ & $\square$ & $\square$ & $\square$ & $\square$ \\
\hline 口 & मயாயாणए & $\square$ & $\square$ & $\square$ & $\square$ & $\square$ \\
\hline Ш & पणாणாणाए & $\square$ & $\square$ & $\square$ & $\square$ & $\square$ \\
\hline$\square$ & मणாயாய & $\square$ & $\square$ & $\square$ & $\square$ & 口 \\
\hline$\square$ & मणनामाए & $\square$ & $\square$ & $\square$ & ए & $\square$ \\
\hline$\square$ & पणामाणाए & 口 & $\square$ & $\square$ & 口 & 口 \\
\hline पा & पमाणाणाए & $\square$ & $\square$ & $\square$ & $\square$ & 口 \\
\hline 11 & मणामणमा & $\square$ & $\square$ & $\square$ & $\square$ & $\square$ \\
\hline$\square$ & पणामाणाम & 口 & $\square$ & $\square$ & $\square$ & 口 \\
\hline$\square$ & पमाणाणाए & 口 & $\square$ & $\square$ & $\square$ & $\square$ \\
\hline प1 & मயாயாவாம & $\square$ & $\square$ & $\square$ & $\square$ & $\square$ \\
\hline$\square$ & 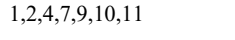 & $\square$ & $\square$ & $\square$ & $\square$ & 口 \\
\hline$\square$ & पमापाणाणए & 口 & $\square$ & $\square$ & $\square$ & प \\
\hline$\square$ & मயयामणाण & $\square$ & $\square$ & $\square$ & $\square$ & $\square$ \\
\hline$\square$ & पमापामाणाए & 口 & $\square$ & $\square$ & $\square$ & $\square$ \\
\hline पा & पणमाणमणए & 口 & $\square$ & $\square$ & $\square$ & 口 \\
\hline पा & ாயாயாயாம & $\square$ & $\square$ & $\square$ & $\square$ & $\square$ \\
\hline$\square$ & मயாயாயாம & $\square$ & $\square$ & $\square$ & $\square$ & $\square$ \\
\hline$\square$ & मामाणमाणए & 口 & $\square$ & $\square$ & $\square$ & $\square$ \\
\hline प1 & मயாயாவாம & $\square$ & $\square$ & ए & $\square$ & 口 \\
\hline$\square$ & 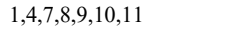 & $\square$ & $\square$ & $\square$ & 口 & 口 \\
\hline$\square$ & मणामणमाण & $\square$ & $\square$ & $\square$ & $\square$ & $\square$ \\
\hline$\square$ & 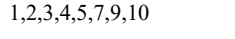 & $\square$ & $\square$ & $\square$ & $\square$ & $\square$ \\
\hline$\square$ & 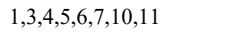 & 口 & $\square$ & $\square$ & $\square$ & $\square$ \\
\hline$\square$ & 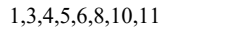 & 口 & $\square$ & $\square$ & $\square$ & $\square$ \\
\hline$\square$ & मயாயாயாயா & $\square$ & $\square$ & $\square$ & $\square$ & $\square$ \\
\hline$\square$ & 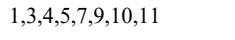 & $\square$ & $\square$ & ए & $\square$ & $\square$ \\
\hline$\square$ & मாயா & 口 & $\square$ & 口 & $\square$ & $\square$ \\
\hline$\square$ & 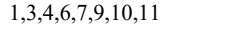 & $\square$ & $\square$ & $\square$ & $\square$ & $\square$ \\
\hline$\square$ & 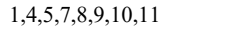 & $\square$ & $\square$ & $\square$ & $\square$ & 口 \\
\hline$\square$ & 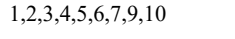 & $\square$ & $\square$ & $\square$ & $\square$ & ए \\
\hline प1 & 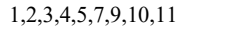 & $\square$ & $\square$ & $\square$ & $\square$ & 口 \\
\hline$\square$ & मणामामामाणाए & $\square$ & $\square$ & ए & $\square$ & $\square$ \\
\hline$\square$ & 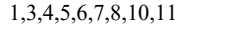 & $\square$ & $\square$ & $\square$ & $\square$ & ए \\
\hline$\square$ & 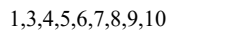 & $\square$ & $\square$ & ए & $\square$ & $\square$ \\
\hline$\square$ & 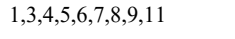 & $\square$ & $\square$ & 口 & $\square$ & $\square$ \\
\hline$\square$ & 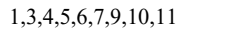 & $\square$ & $\square$ & $\square$ & $\square$ & 口 \\
\hline प1 & 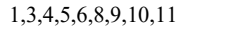 & $\square$ & $\square$ & $\square$ & $\square$ & $\square$ \\
\hline$\square$ & 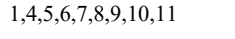 & $\square$ & $\square$ & 口 & $\square$ & 口 \\
\hline$\square$ & 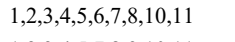 & एा & $\square$ & $\square$ & $\square$ & 口 \\
\hline$\square$ & 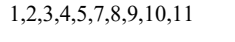 & $\square$ & $\square$ & $\square$ & $\square$ & ए \\
\hline$\square$ & 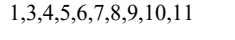 & $\square$ & $\square$ & $\square$ & 口 & $\square$ \\
\hline$\square \square$ & 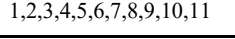 & $\square$ & $\square$ & $\square$ & $\square$ & $\square$ \\
\hline$\square$ & 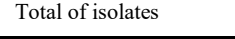 & $\square$ & $\square \square$ & $\square \square$ & $\square$ & $\square \square$ \\
\hline
\end{tabular}




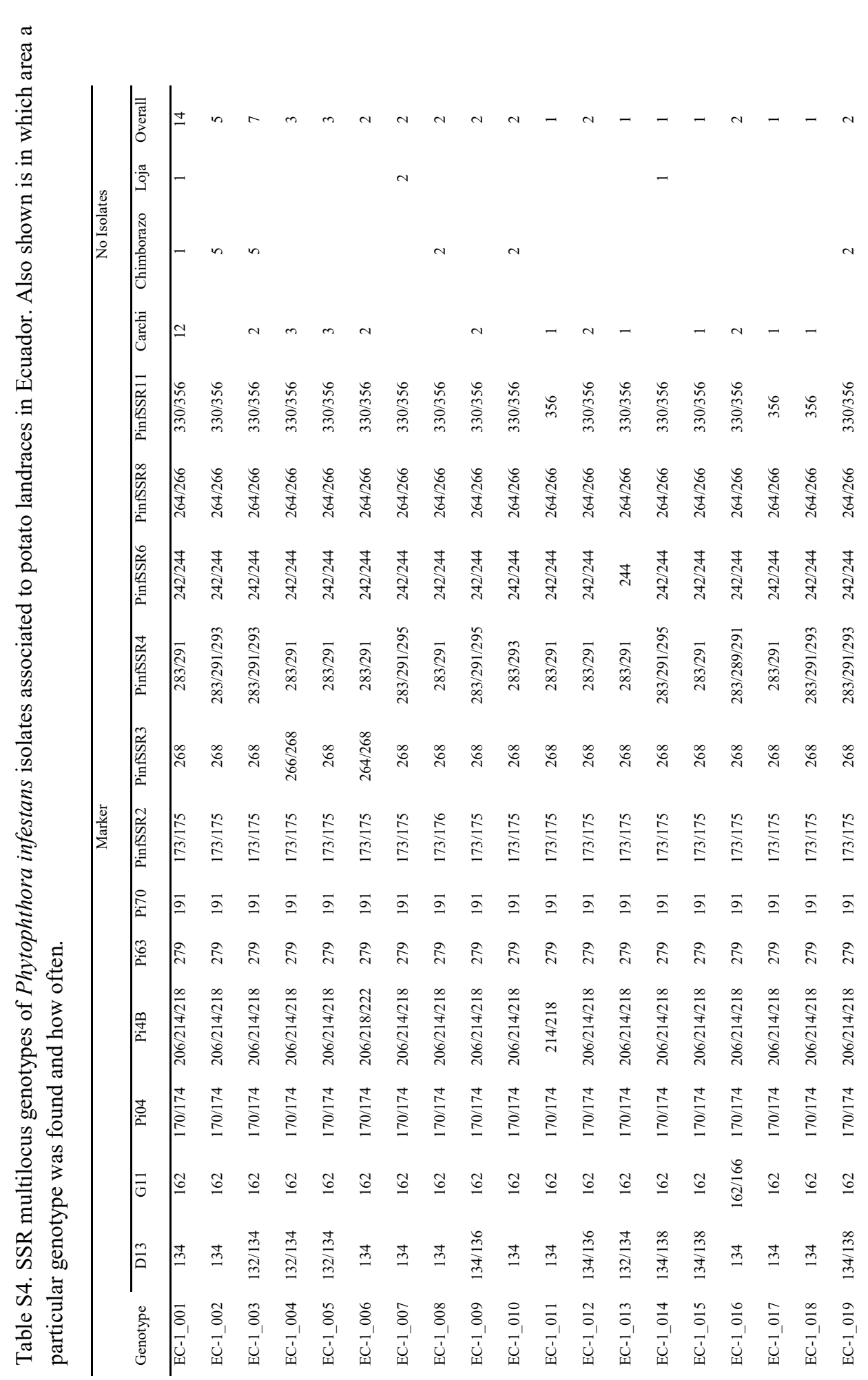




$$
\begin{aligned}
& \boxminus \quad \boxminus \quad \boxminus \quad \boxminus \quad \boxminus \quad \boxminus \quad \boxminus \quad \boxminus \quad \boxminus \quad \boxminus \quad \boxminus \quad \boxminus \\
& \square \square \square \square \quad \square \quad \boxminus \quad \boxminus \quad \boxminus \quad \boxminus \quad \boxminus \quad \square \quad \text { 田 } \\
& \square \square \quad \boxminus \quad \boxminus \quad \square \quad \square \quad \square \quad \square \quad \square \quad \square \quad \boxminus \\
& \boxminus \quad \boxminus \square \square \square \quad \square \quad \square \quad \square \quad \square \quad \square \quad \boxminus \quad \boxminus
\end{aligned}
$$

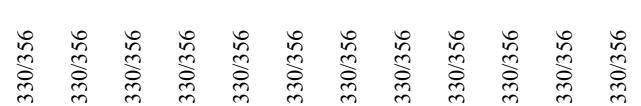

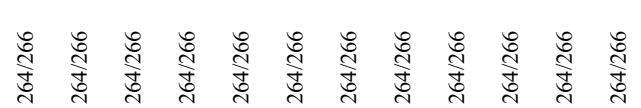

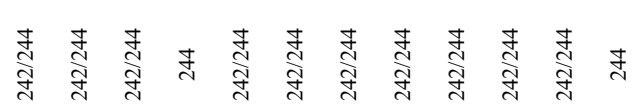

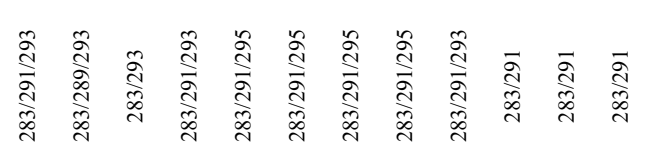

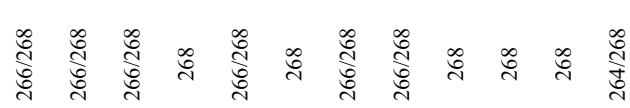

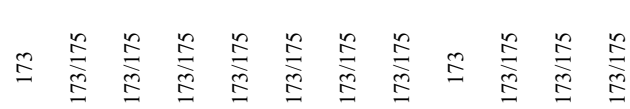

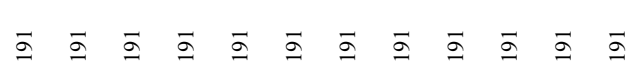

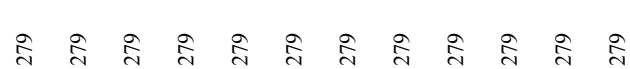

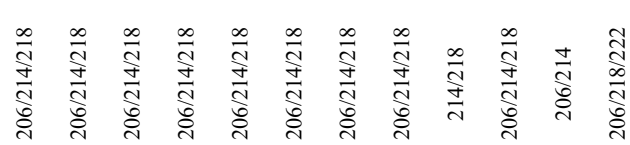

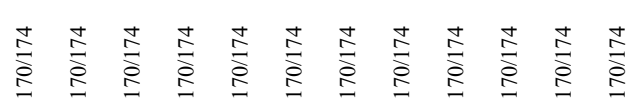

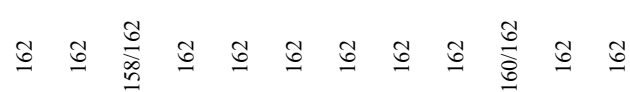

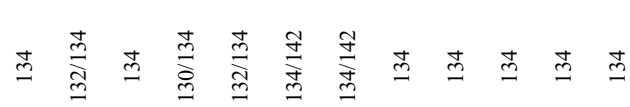

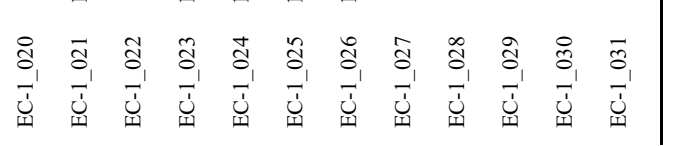




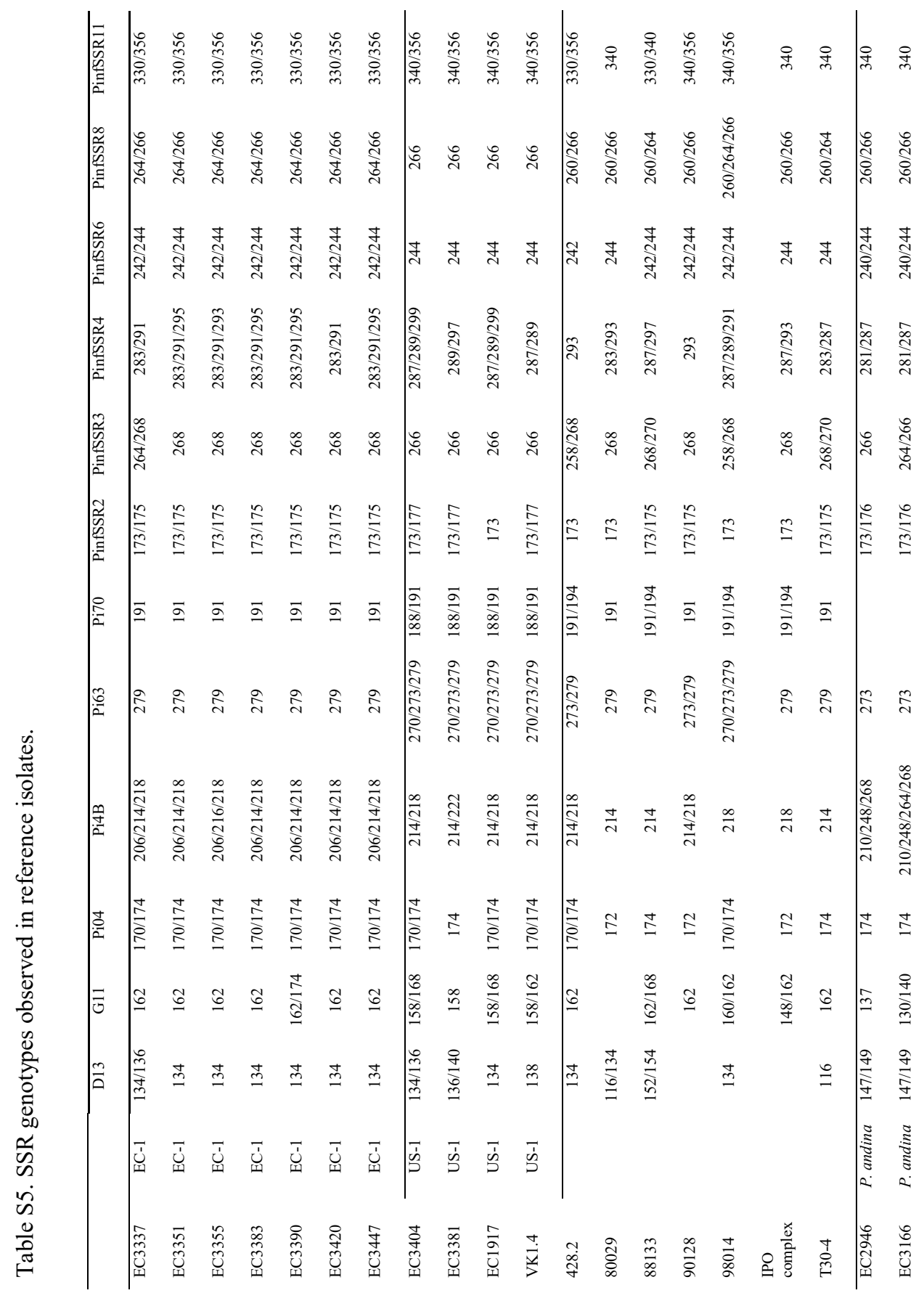




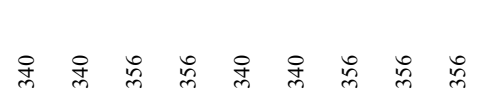

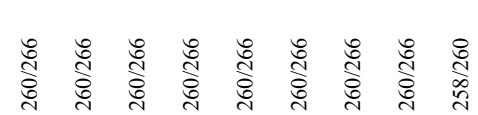

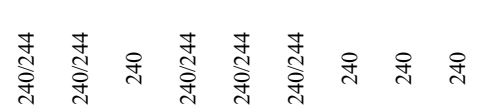

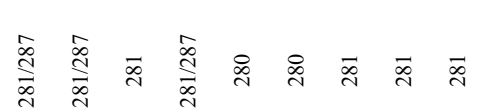

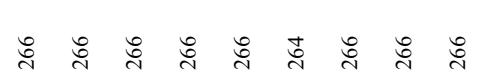

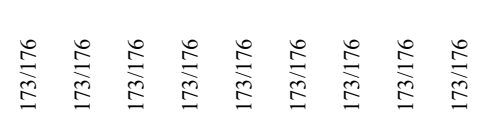

$$
\begin{aligned}
& \exists \boxminus \square \quad \exists \quad \exists \quad \square \quad \square \quad \exists \\
& \exists \quad \exists \quad \exists \quad \exists \quad \exists \quad \exists \quad \exists \quad \exists
\end{aligned}
$$

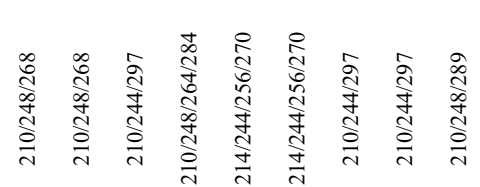

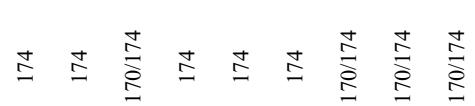

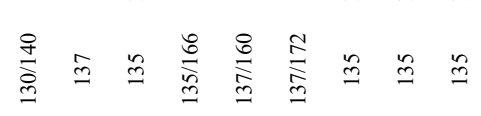

$$
\begin{aligned}
& \square \quad \exists \quad \exists \quad \exists \quad \exists \quad \exists \quad \exists \quad \exists \quad
\end{aligned}
$$

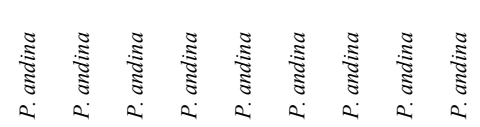

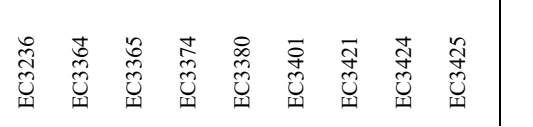




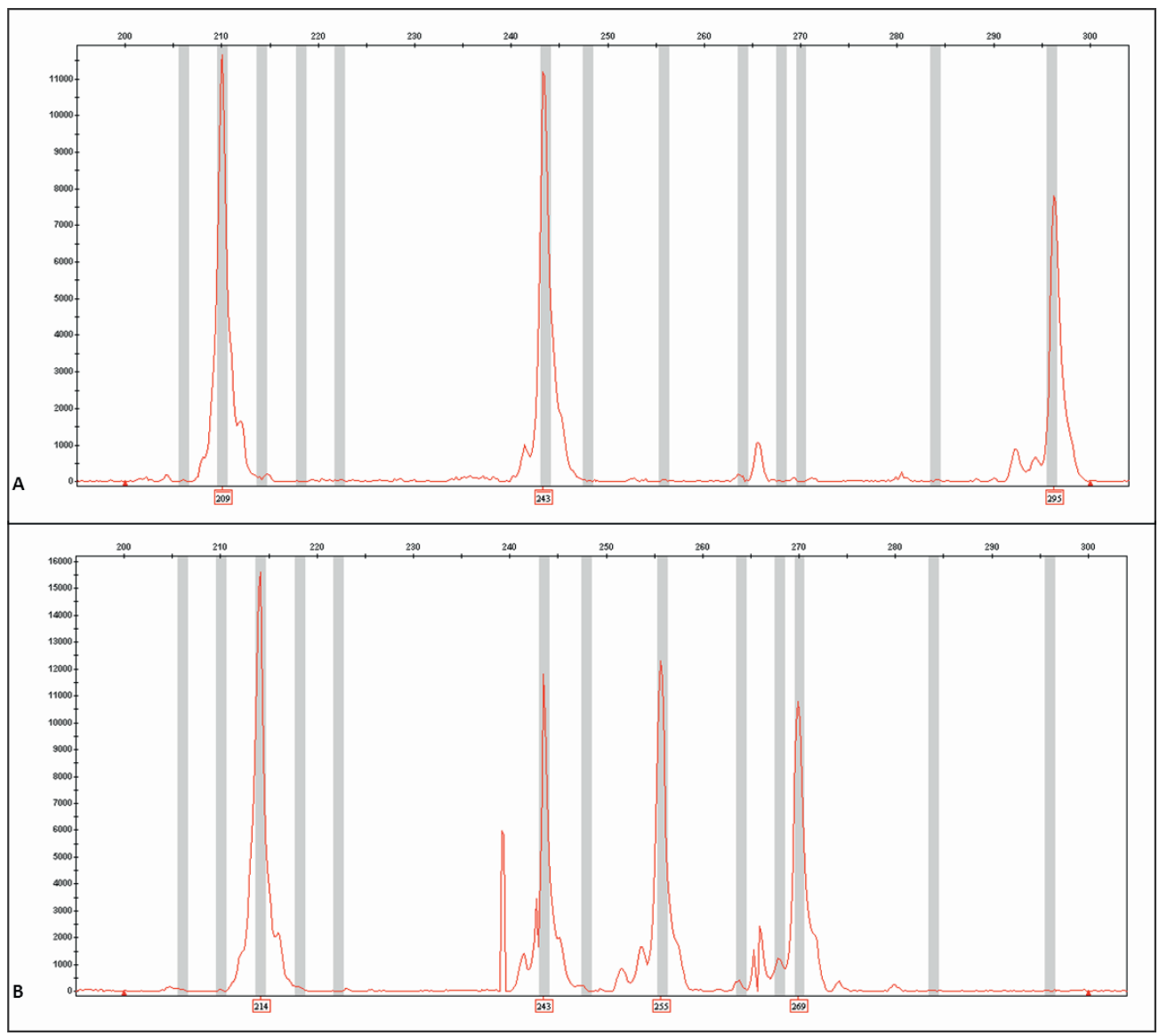




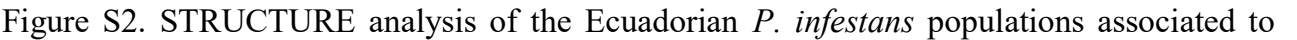

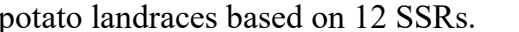

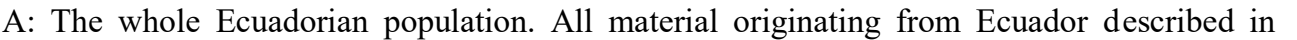

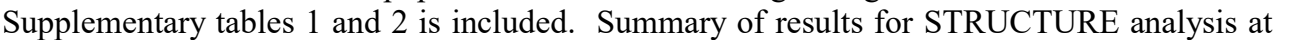

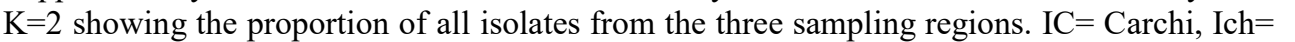

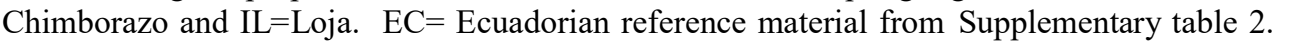

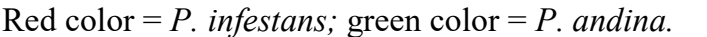

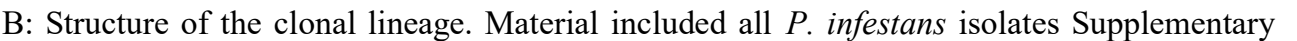

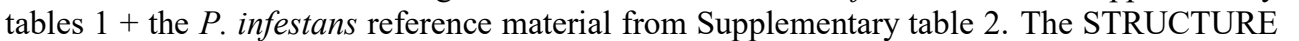

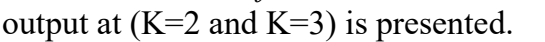
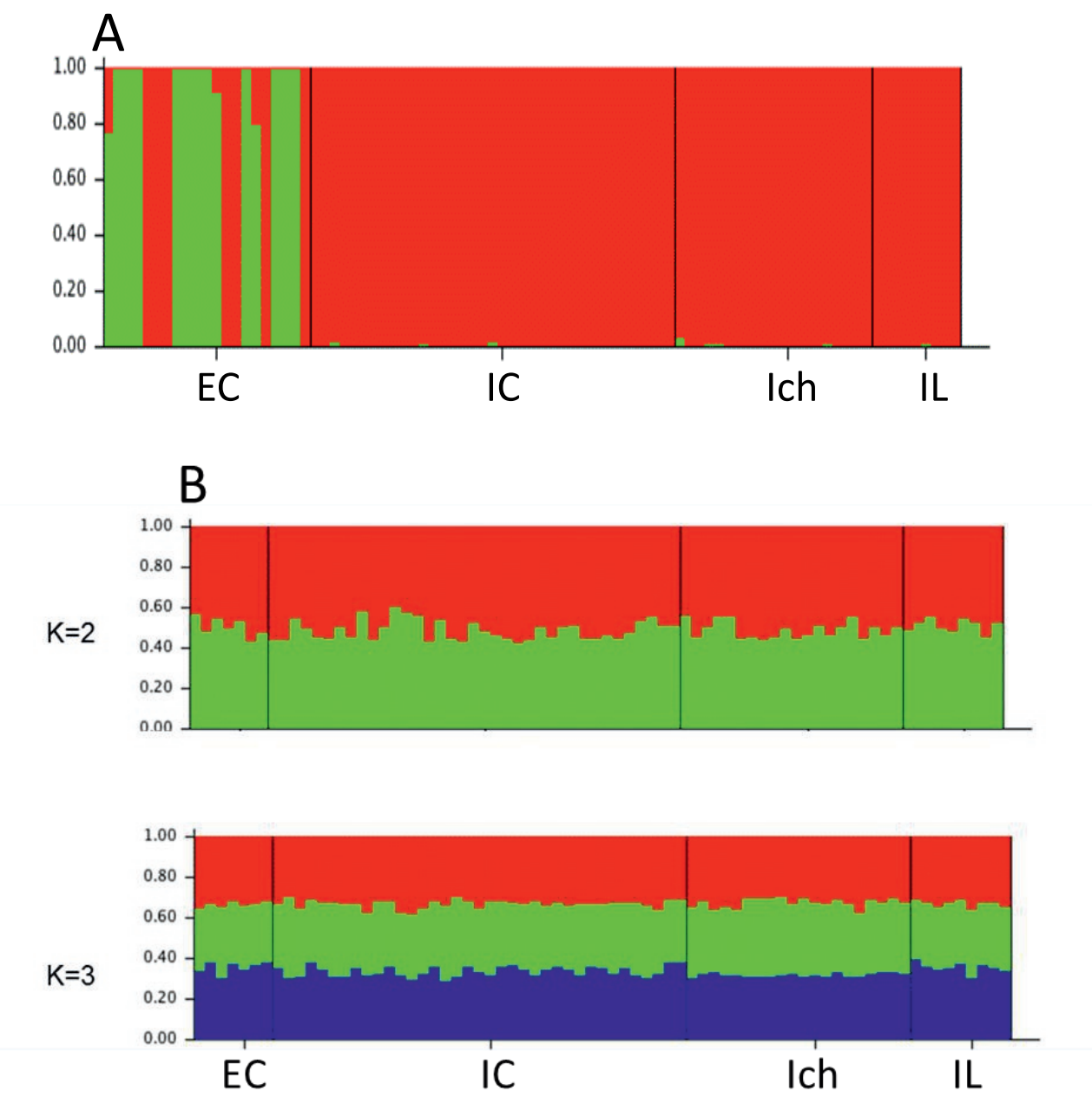


\section{Chapter 4}

\section{Exploring the reaction of Ecuadorian potato landraces to late blight}

$\square$

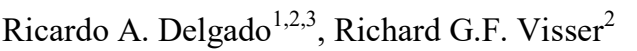

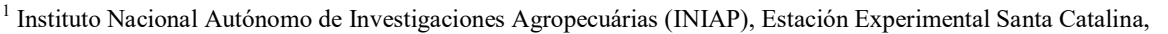

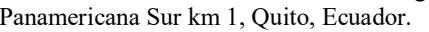

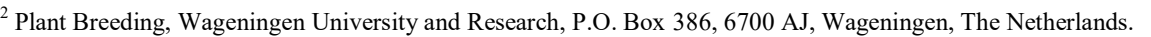

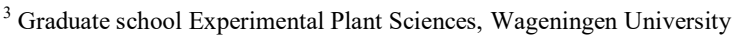

$\square$

$\square$

\section{Abstract}

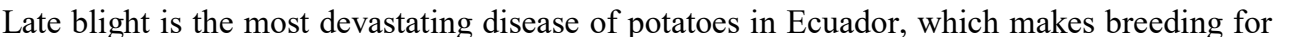

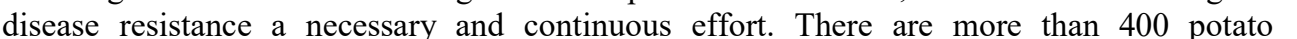

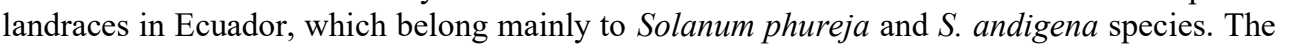

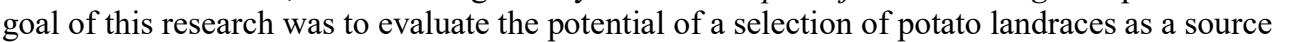

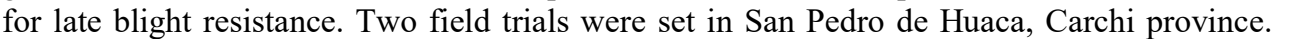

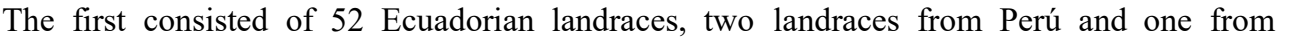

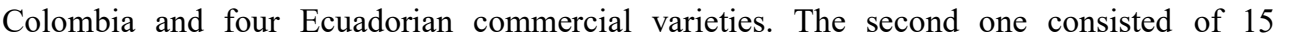
ए ए।

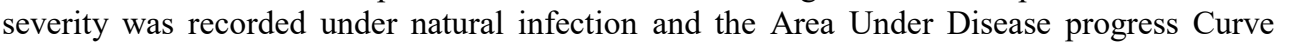

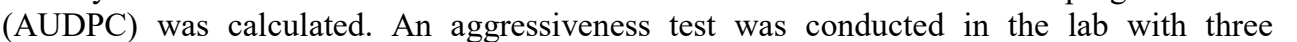

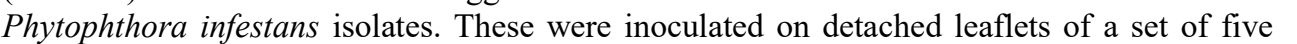

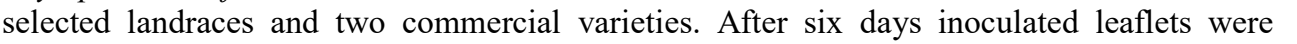

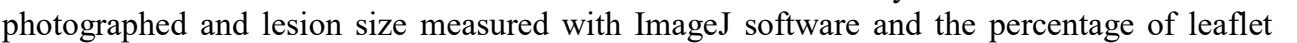

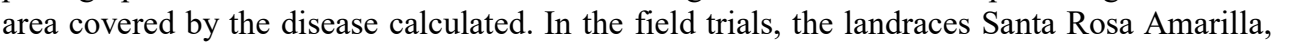

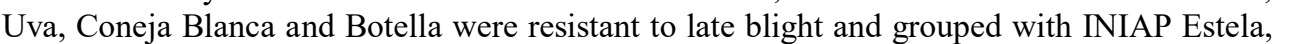

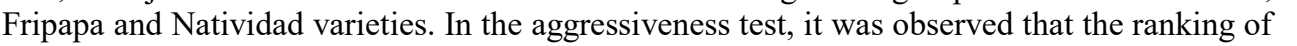

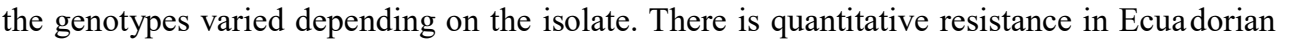

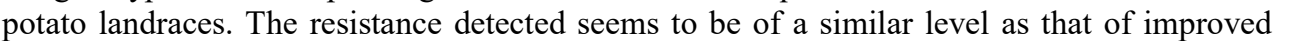

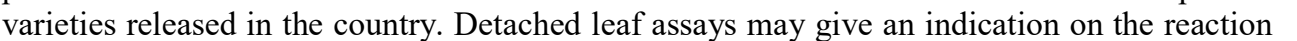

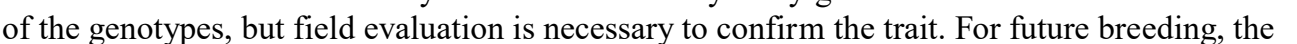

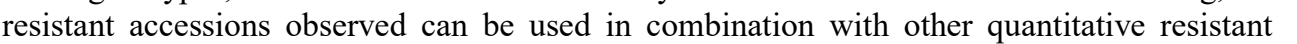

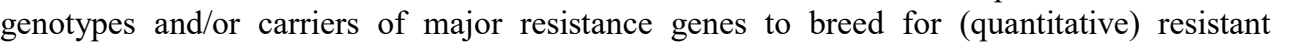

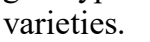

$\square$

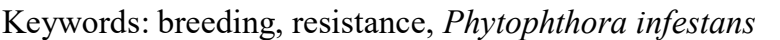

$\square$ 


\section{Introduction}

$\square$

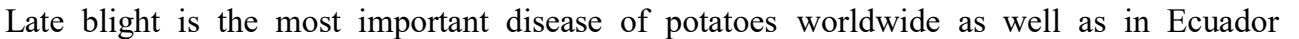

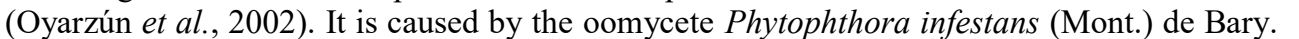

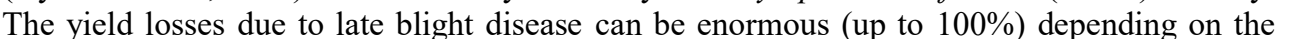

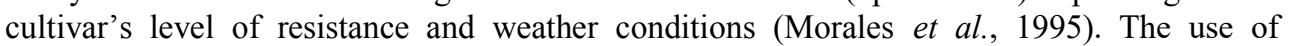

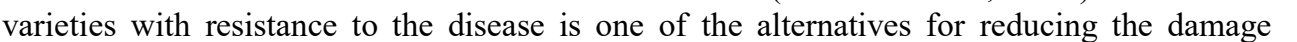

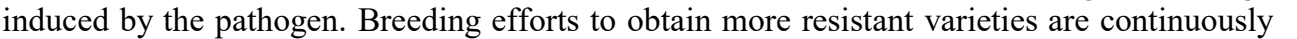

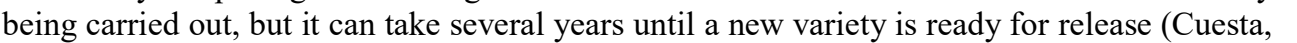

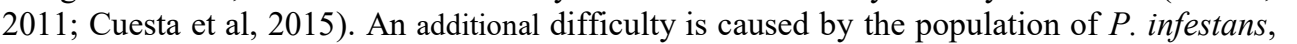

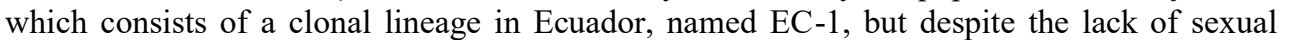

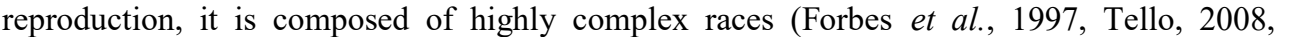

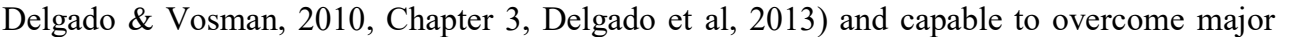

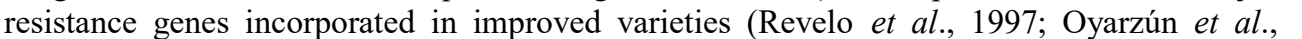

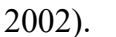

$\square$

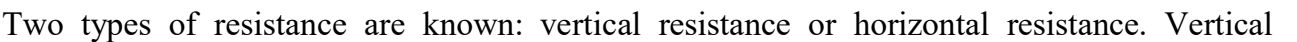

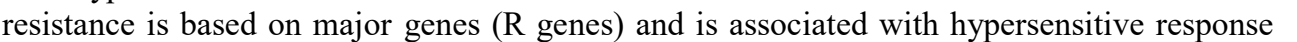

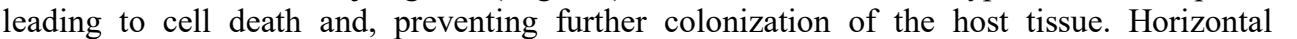

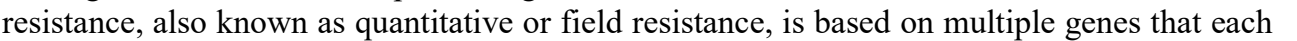

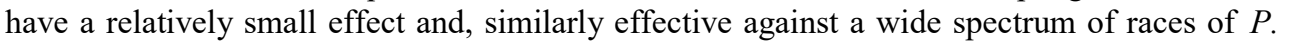

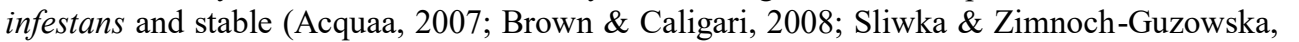
$\square|| ⿴ 囗 ⿰ 丿 ㇄ 丁)$

$\square$

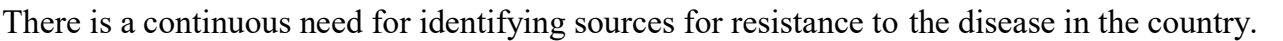

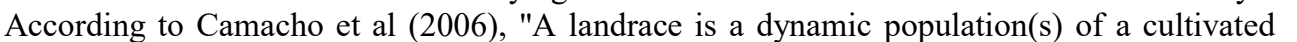

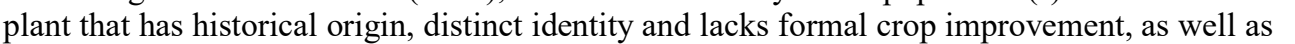

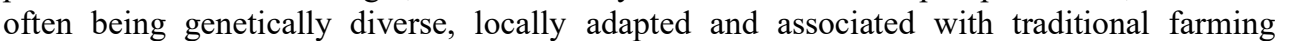

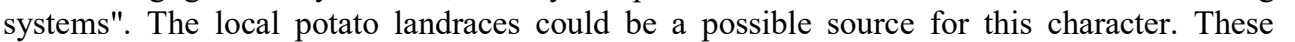

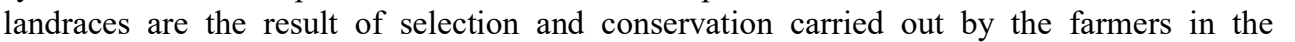

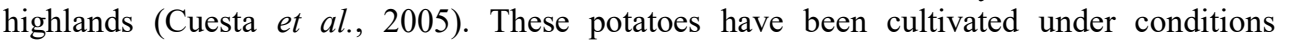

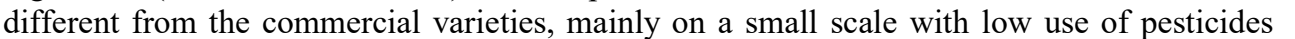

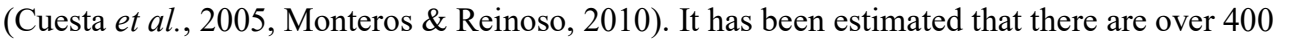

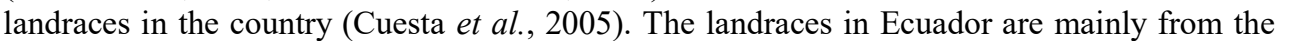

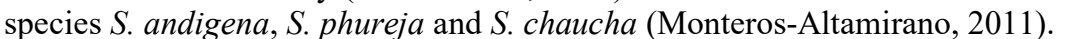
$\square$

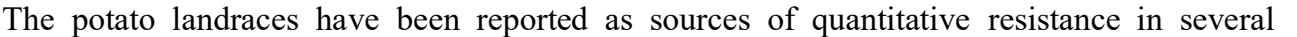

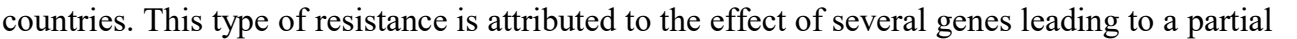

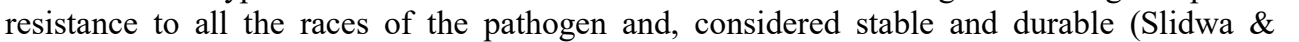

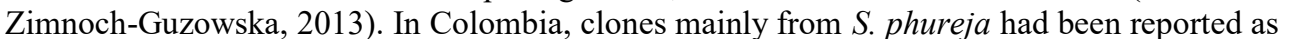

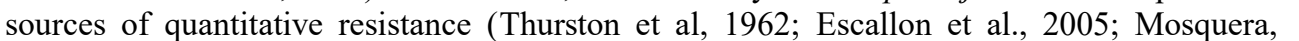

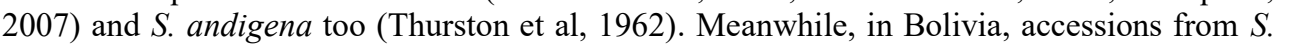

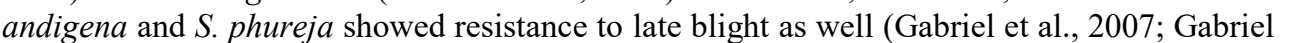

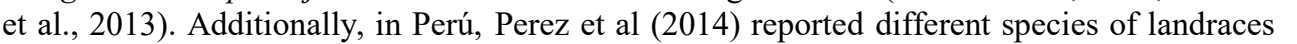

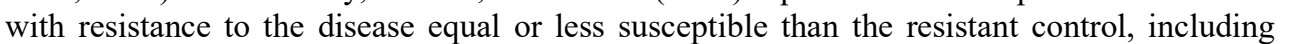

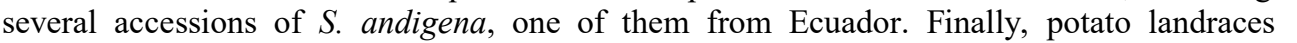

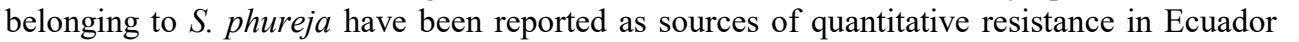

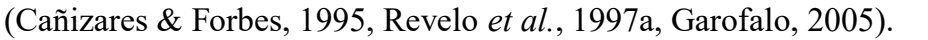




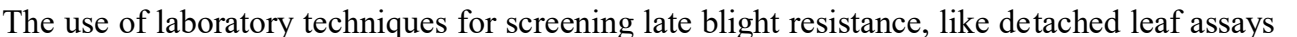

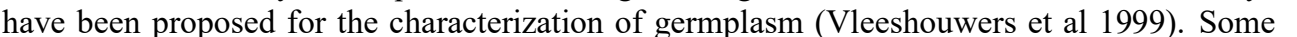

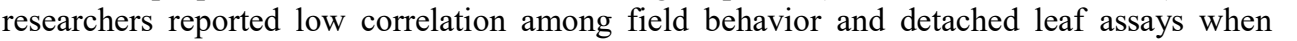

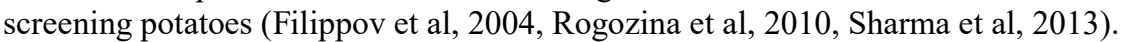

$\square$

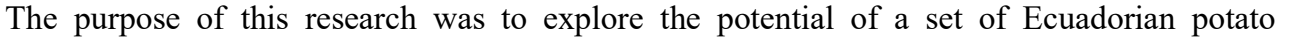
प ए

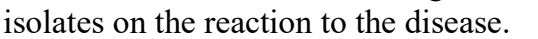

$\square$

\section{Materials and methods}

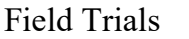

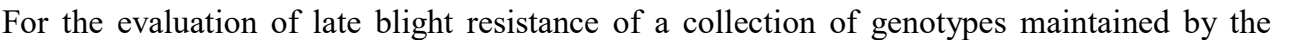

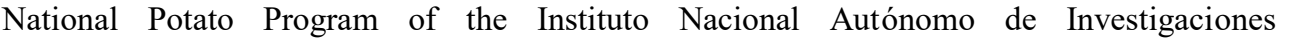

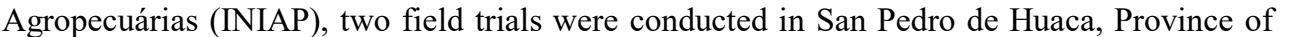

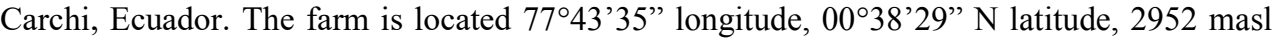

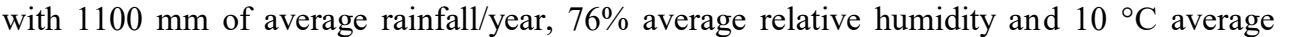

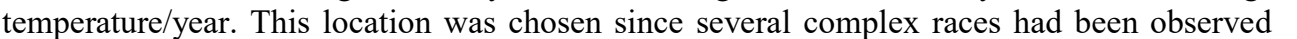

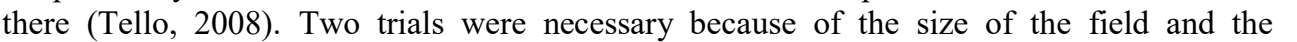

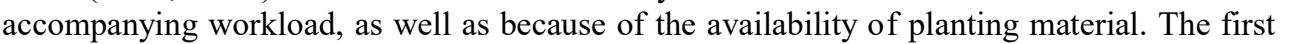

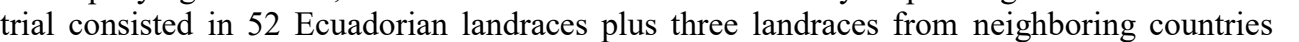

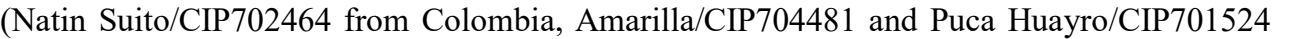

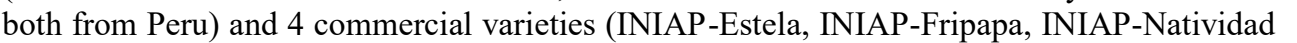

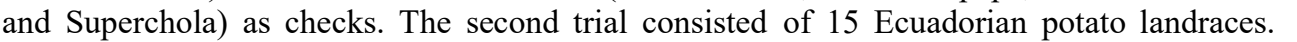

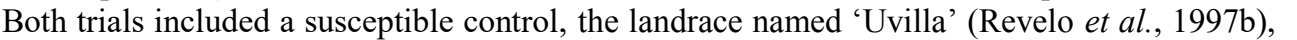

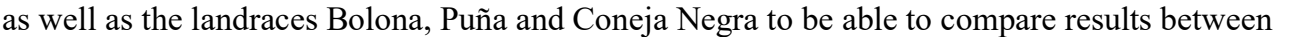
प

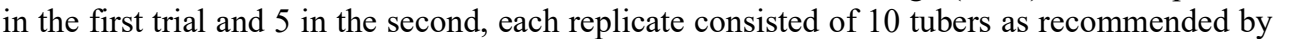

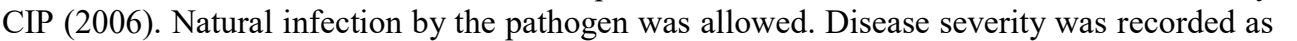

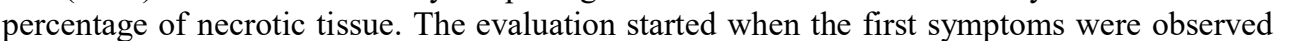

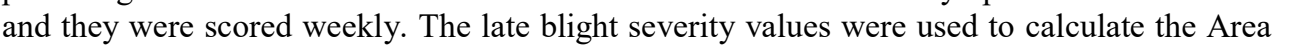

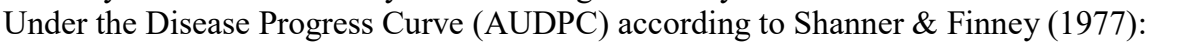

एाmाmए।

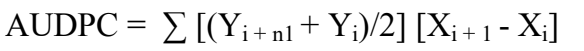

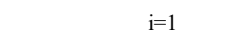

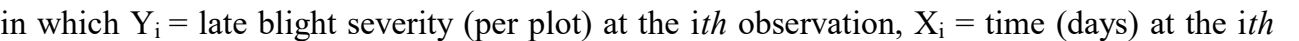

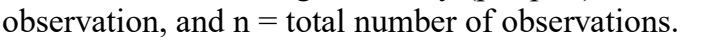

$\square$

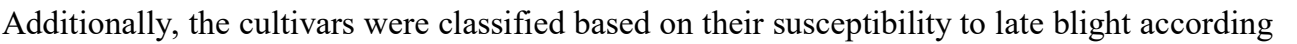

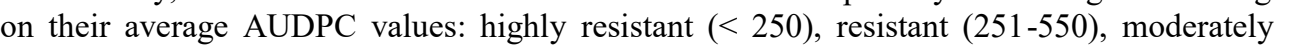




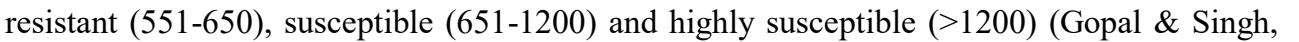
$\square\rceil\|\|$

$\square$

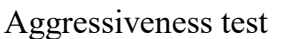

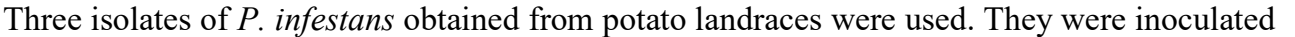

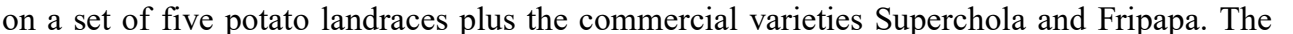

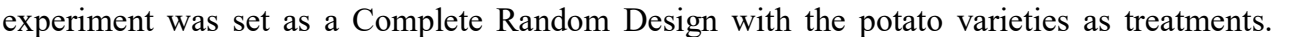

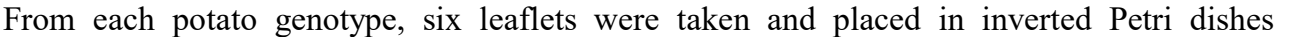

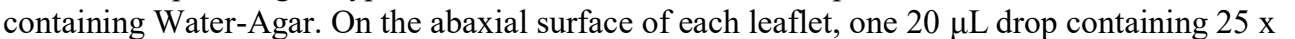

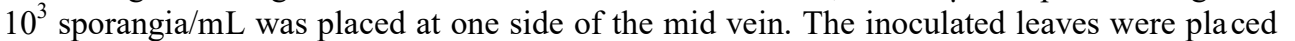

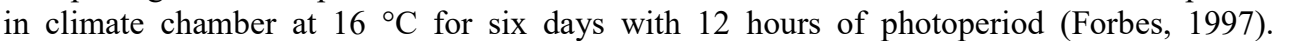

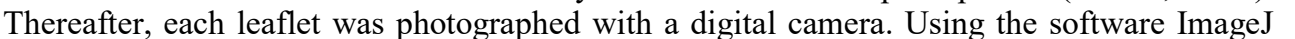

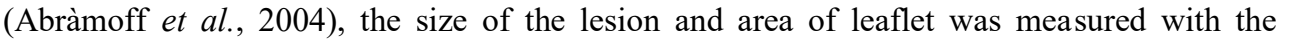

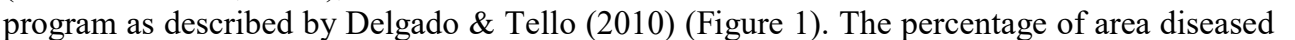

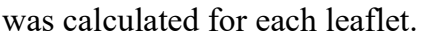

$\square$

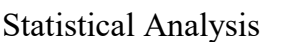

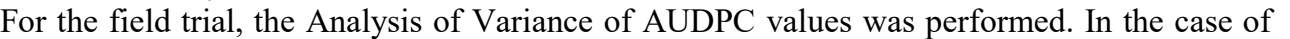
ए ए

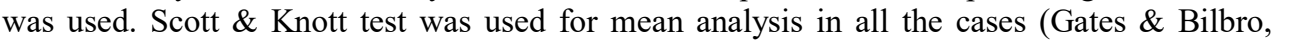
$\square|| ⿴ 囗 十)$

$\square$

\section{Results}

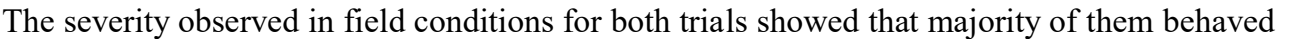

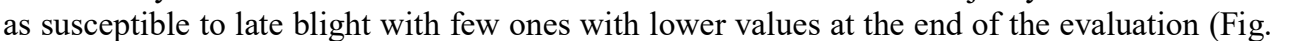

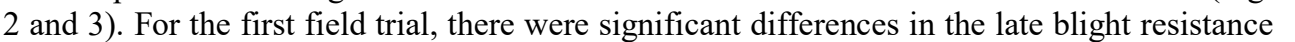

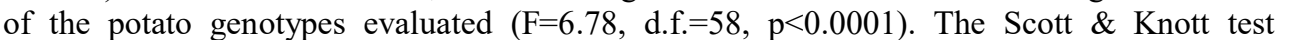

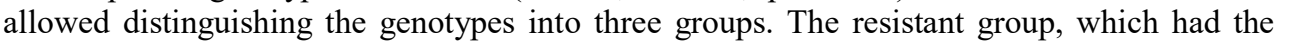

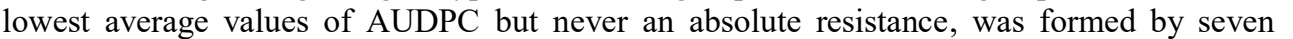

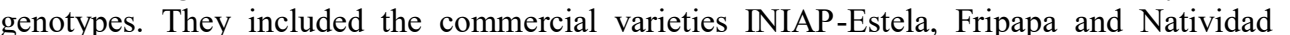
ए

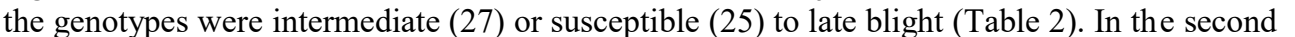

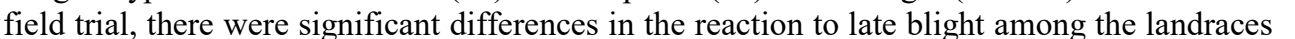

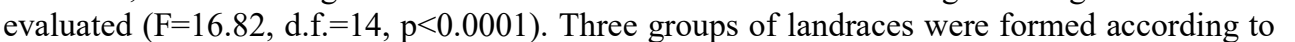

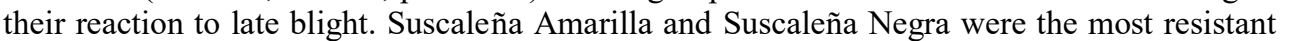

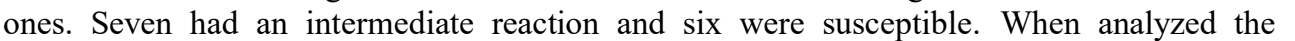

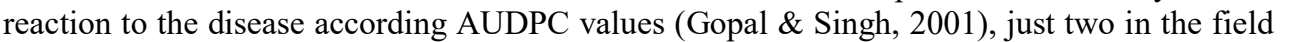

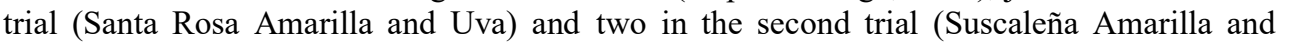

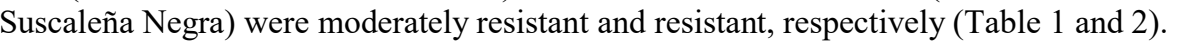

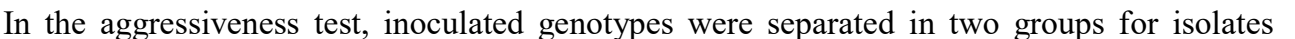

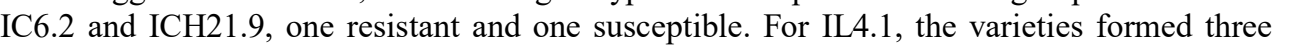

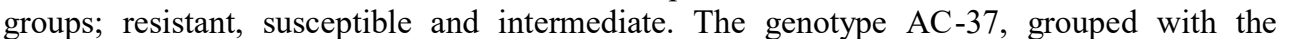

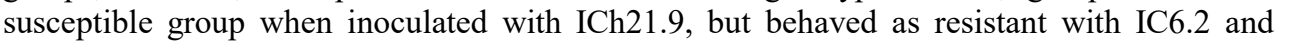




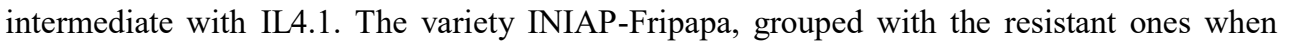
ए

\section{Discussion}

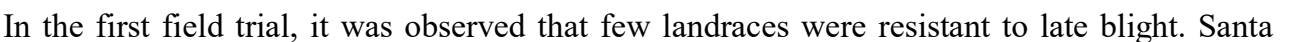

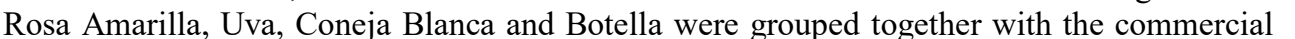

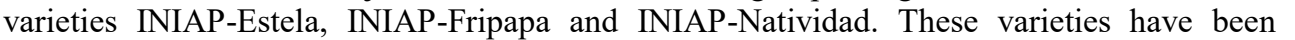

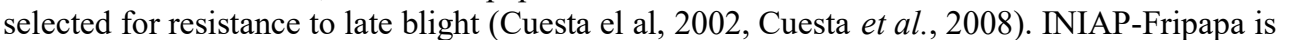

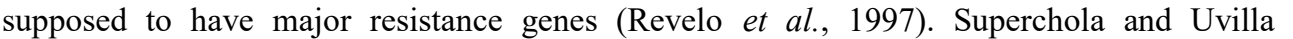

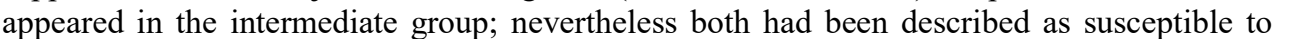

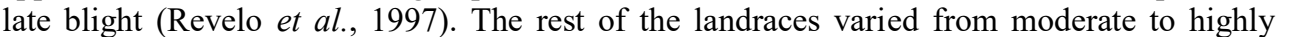

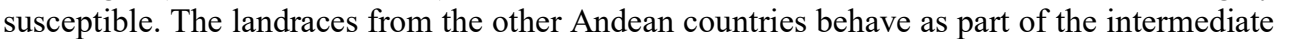

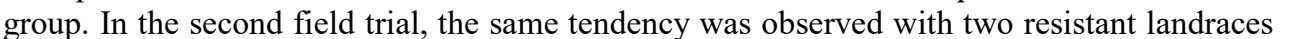

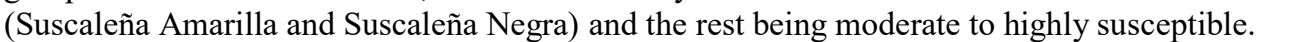

$\square$

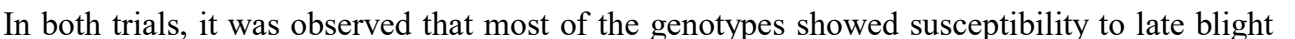

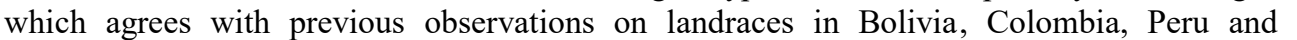

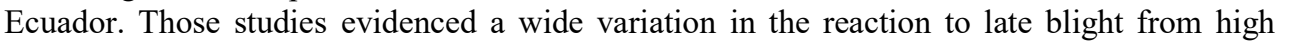

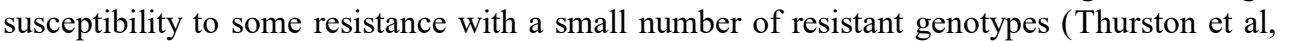

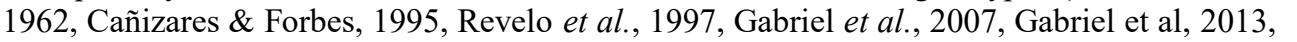

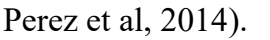

$\square$

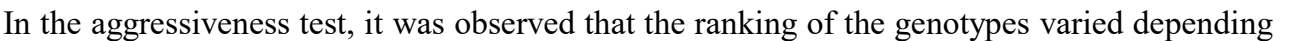

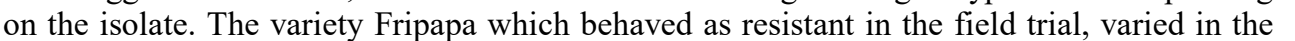

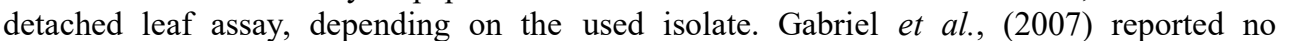

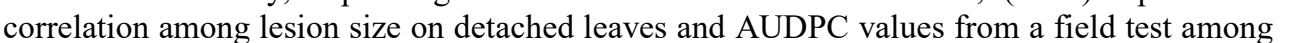

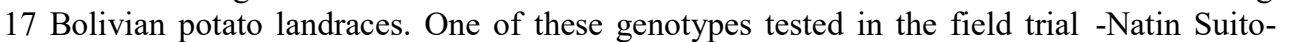

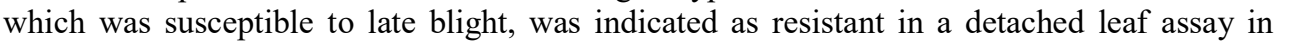

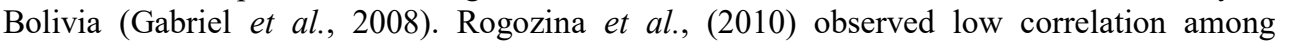
ए ए।

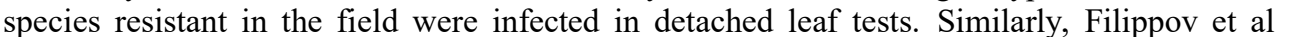

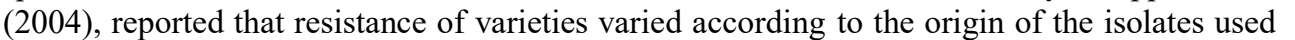

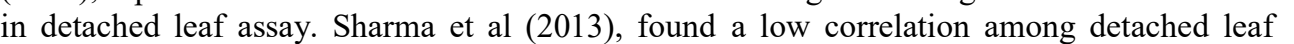

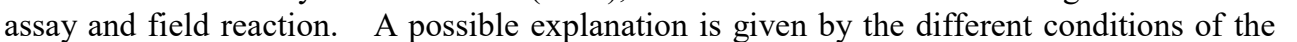

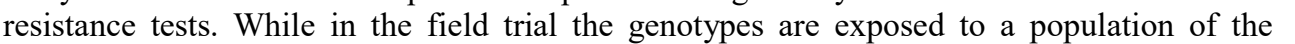

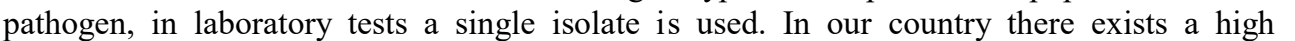

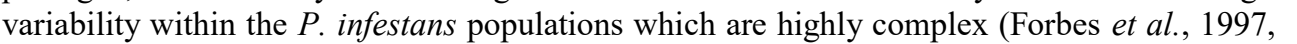

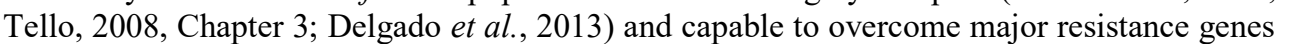

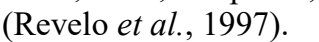

$\square$

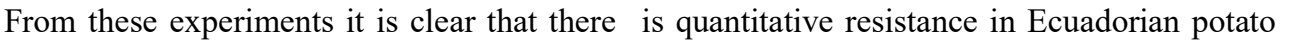

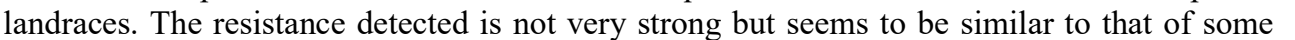




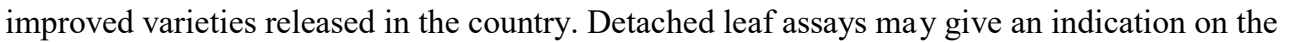

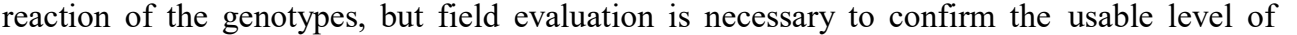
एवाणाणाणा

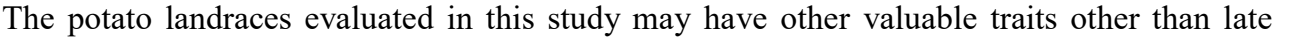

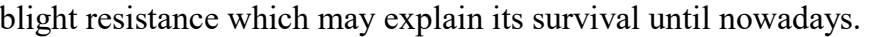

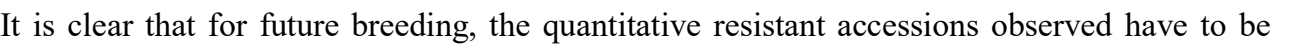

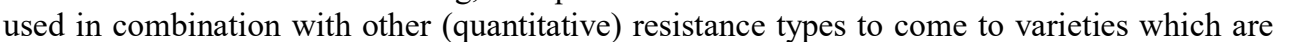

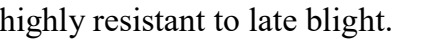

$\square$

\section{Acknowledgments}

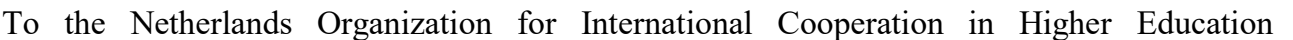

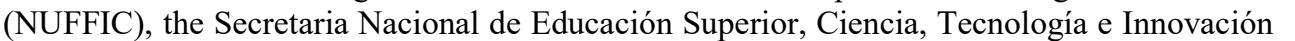

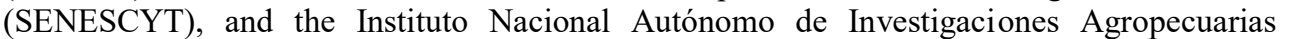

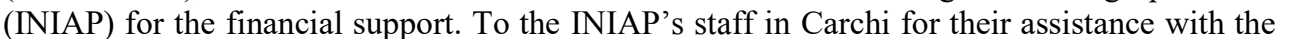

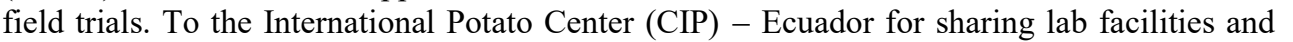

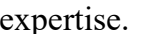

$\square$

\section{Literature cited}

$\square$

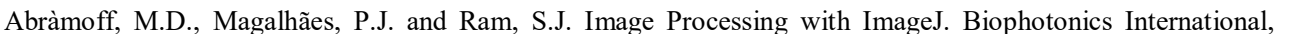

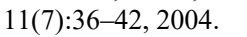

$\square$

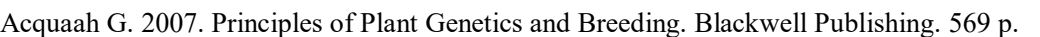

$\square$

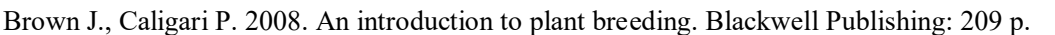

$\square$

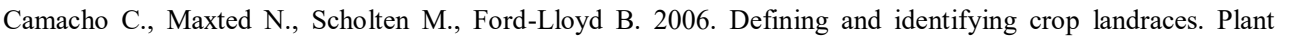

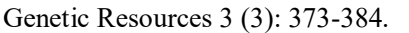
$\square$

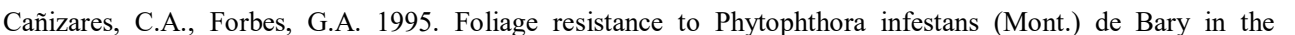

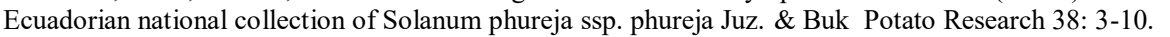
$\square$

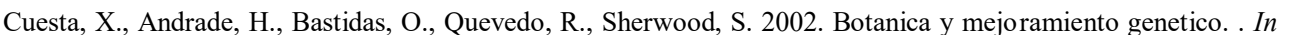

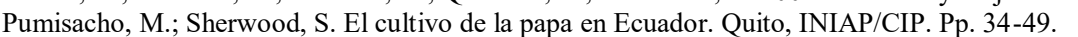

$\square$

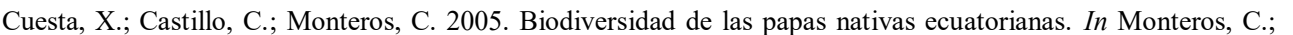

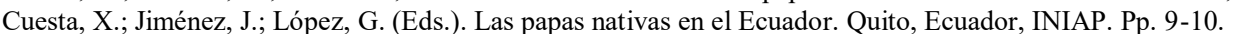
$\square$

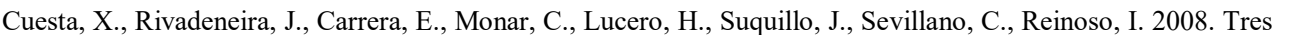

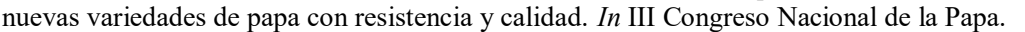
$\square$

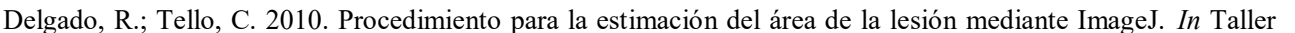

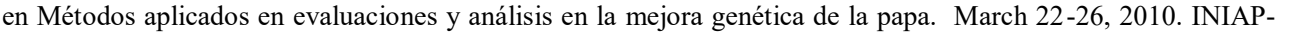

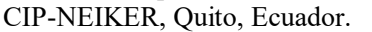

$\square$

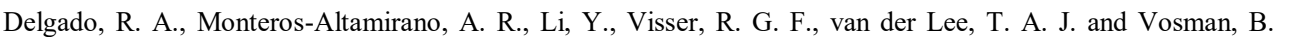

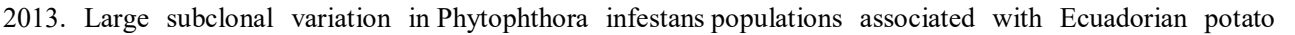

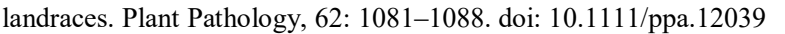


$\square$

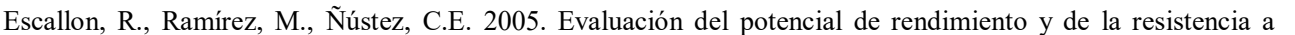

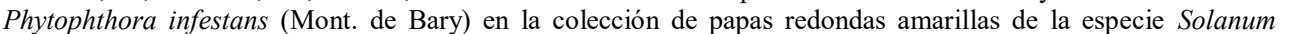

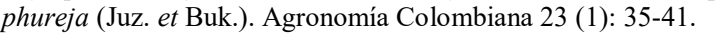

$\square$

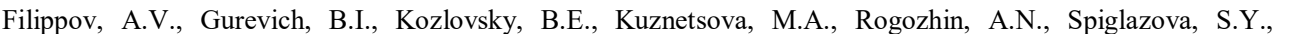
प्र

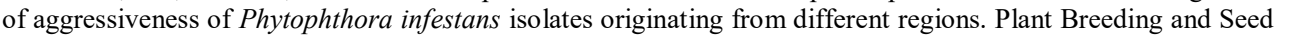

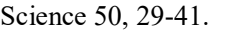

$\square$

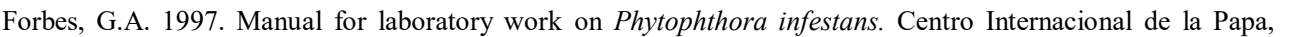

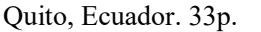

$\square$

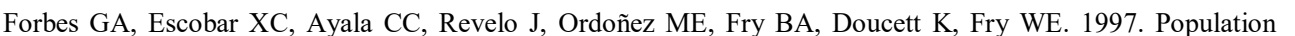

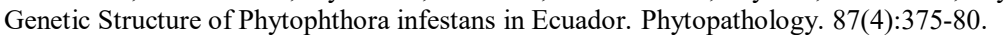

$\square$

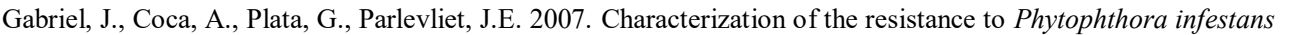

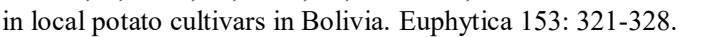

$\square$

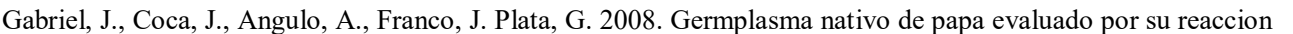

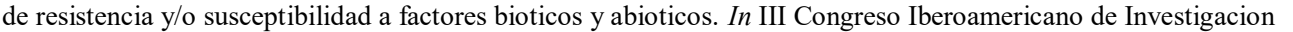

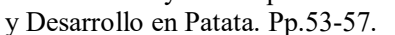

$\square$

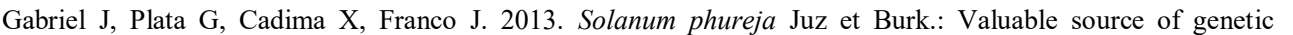

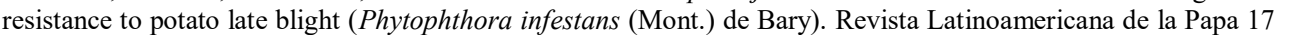
एणाणाणमाण

$\square$

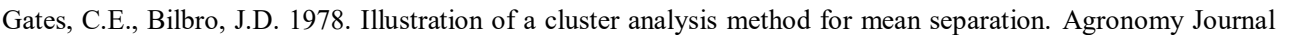

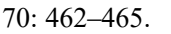

$\square$

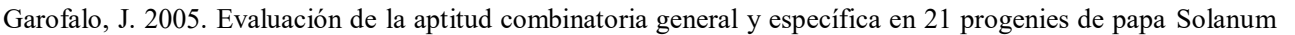

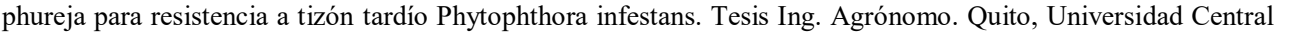

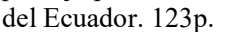

$\square$

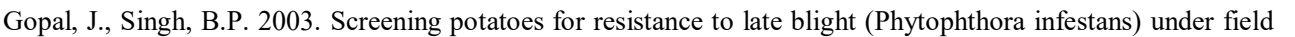

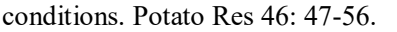
$\square$

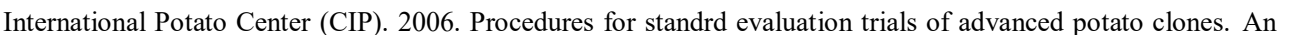
international Cooperator's Guide. Lima, Perú: CIP.

$\square$

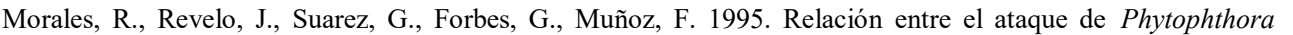

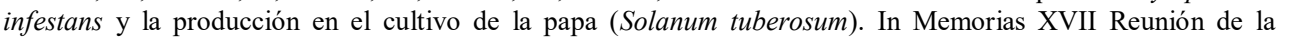

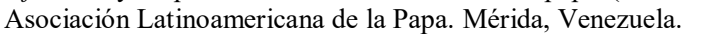

$\square$

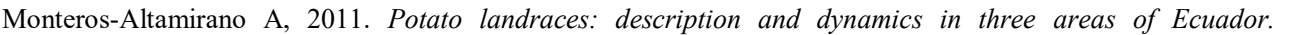

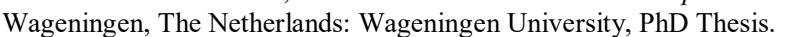

$\square$

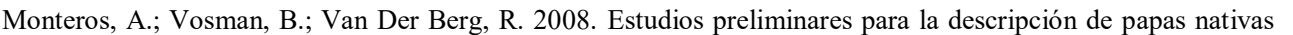

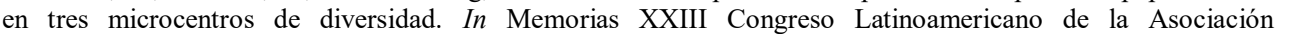

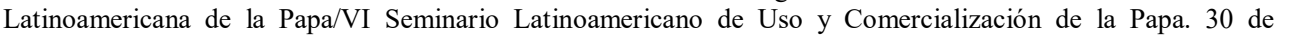

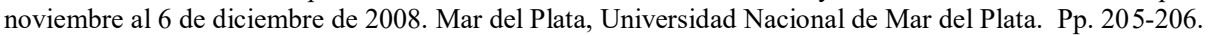
$\square$

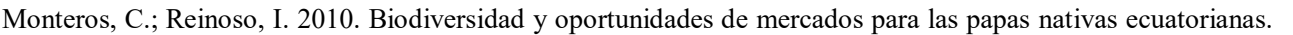

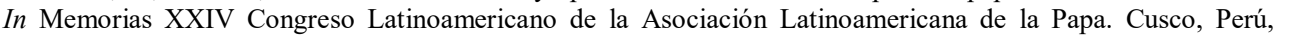

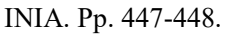

$\square$

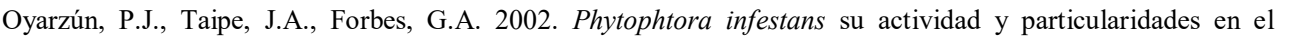

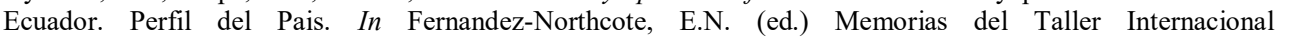

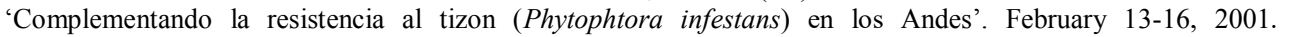

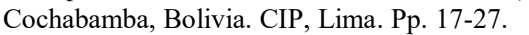


$\square$

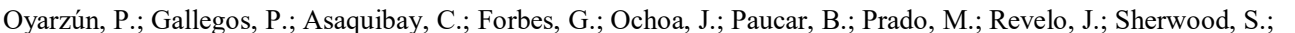

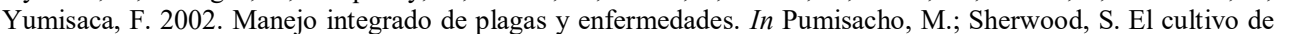

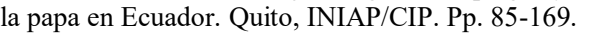

$\square$

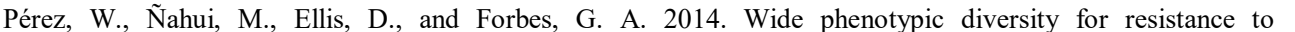

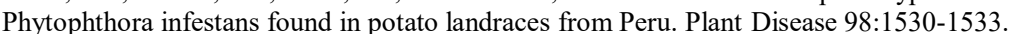

$\square$

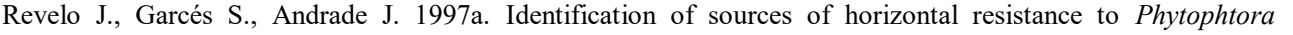

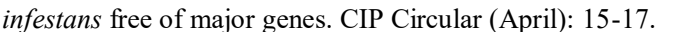

$\square$

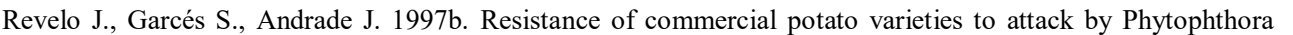

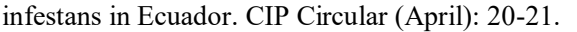

$\square$

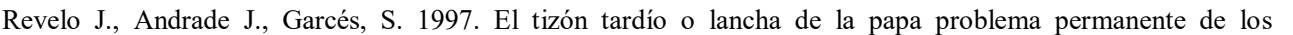

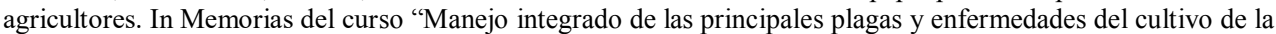

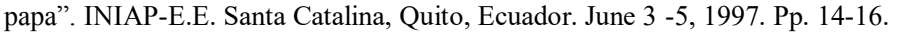

$\square$

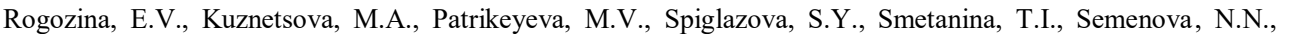

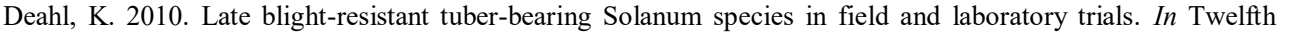

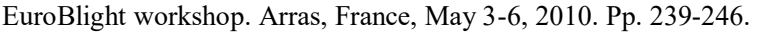
$\square$

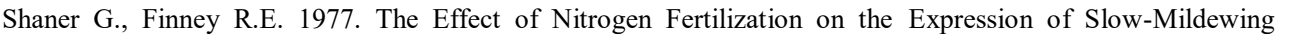

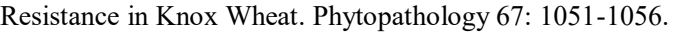

$\square$

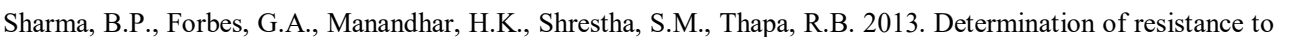

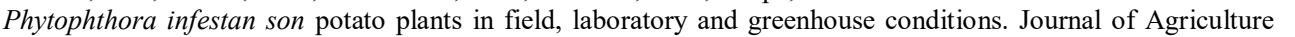

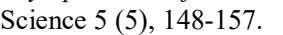

$\square$

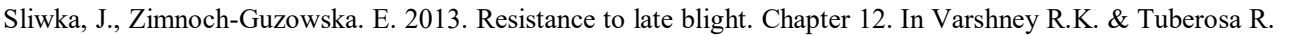

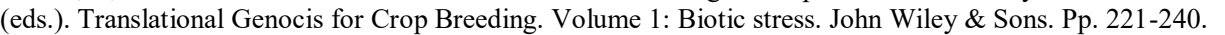
$\square$

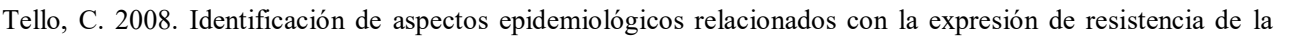

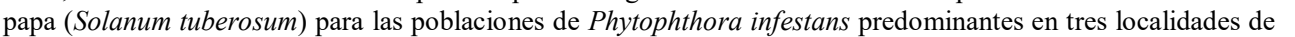

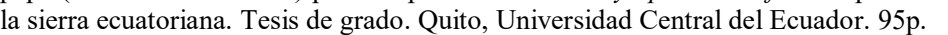
$\square$

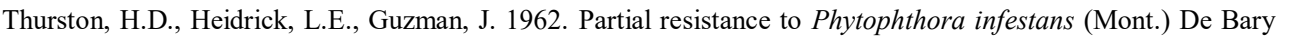

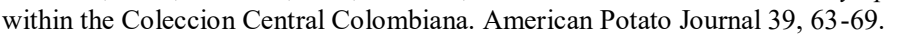
$\square$

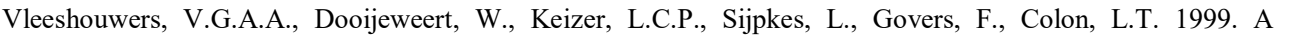

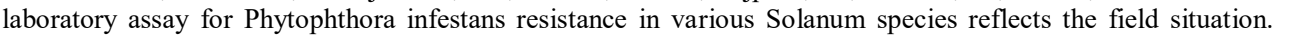

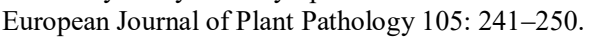




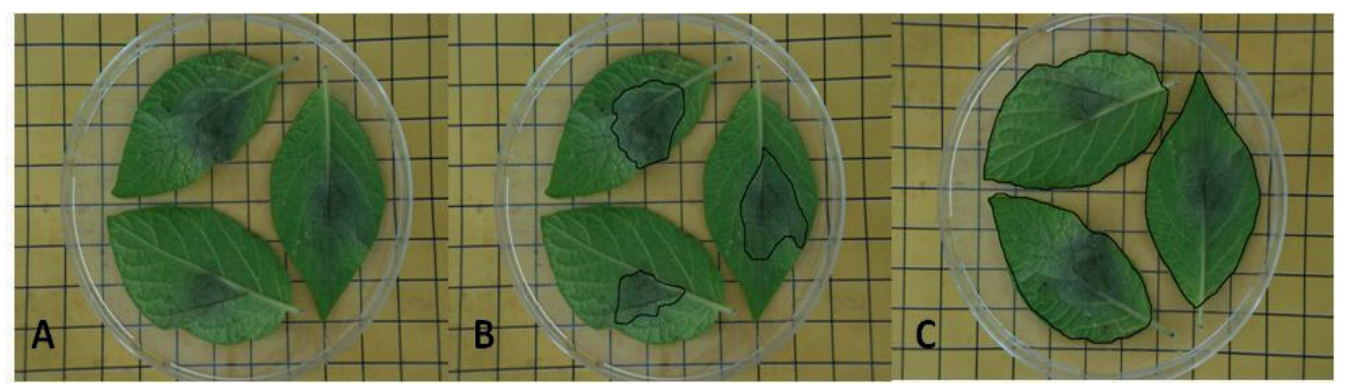

Figure 1.

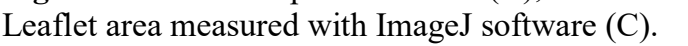

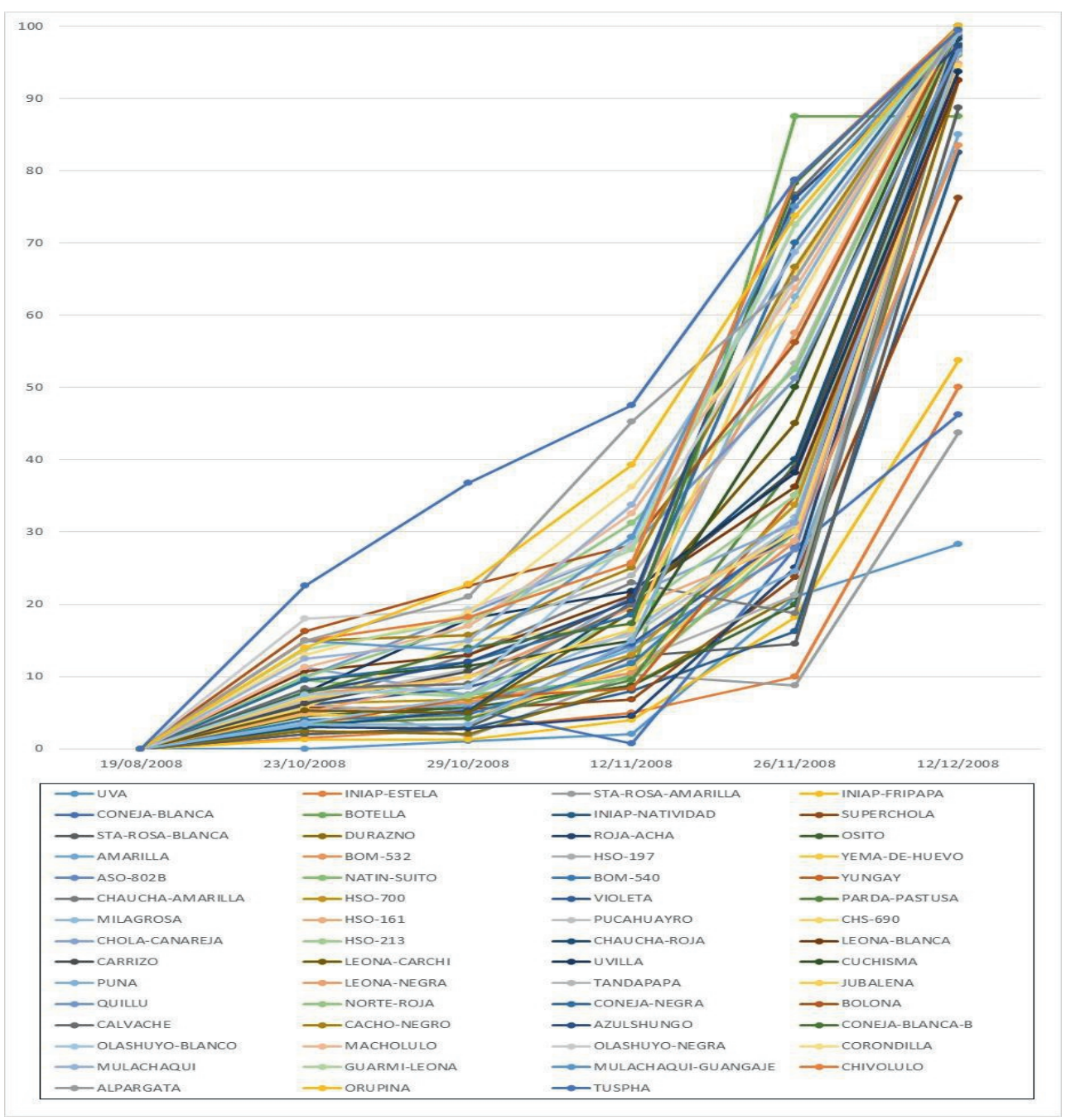

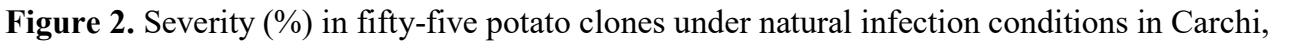

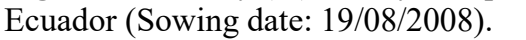




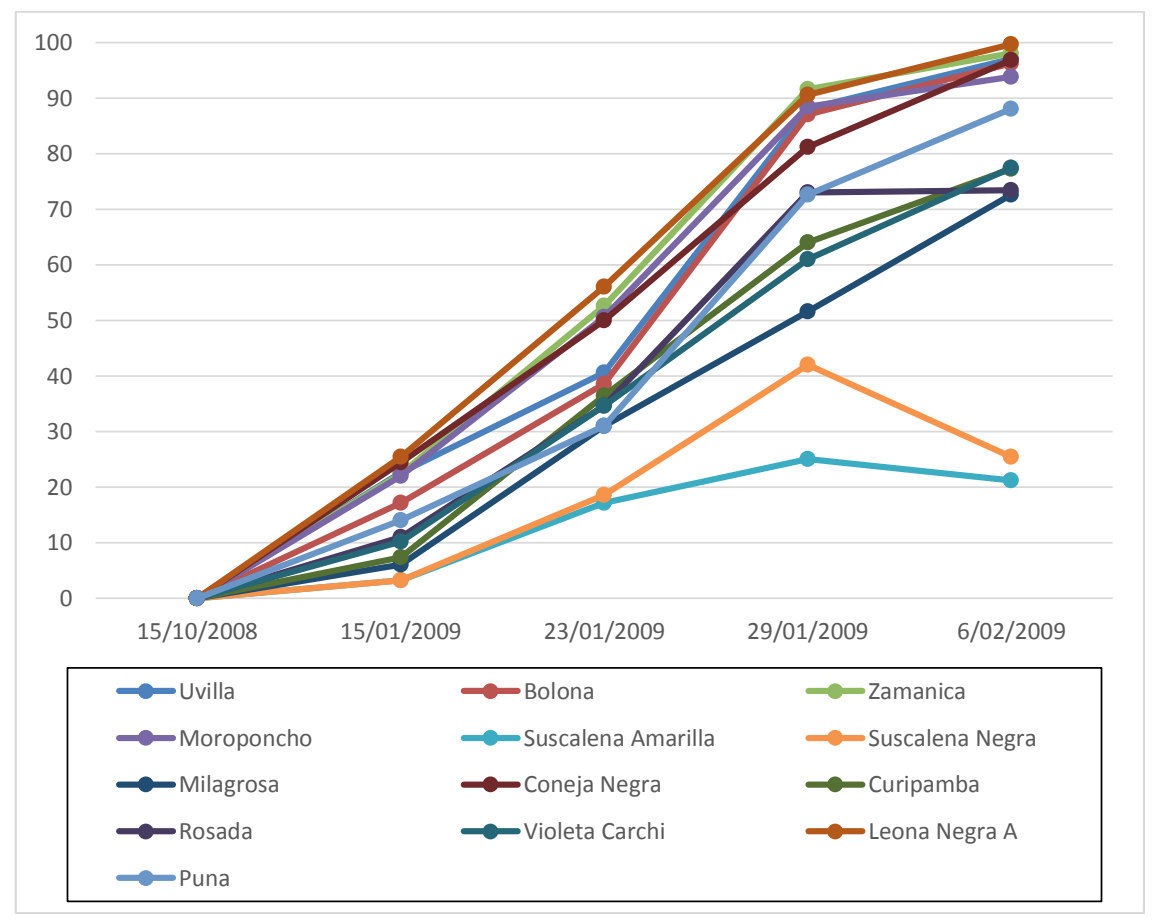

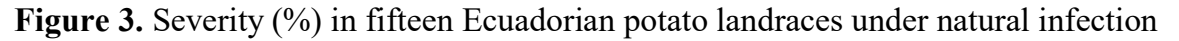

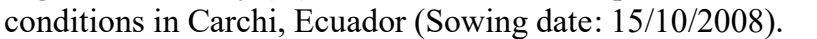

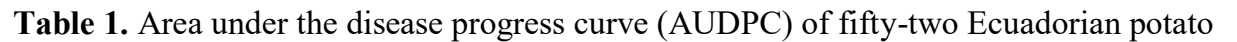

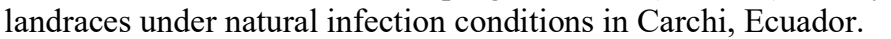

\begin{tabular}{|c|c|c|}
\hline 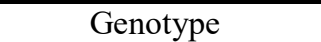 & $\square \square \square[$ & $\square \square \square \square \square \square$ \\
\hline 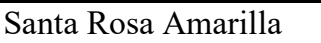 & $\mathrm{mW}$ & 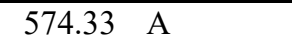 \\
\hline 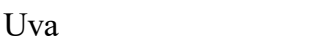 & $\square \square$ & 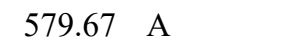 \\
\hline 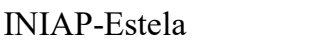 & $\square \square$ & $\square \| \square \square \square \square$ \\
\hline 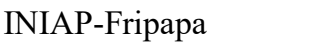 & $\square \square$ & 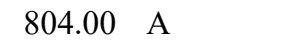 \\
\hline 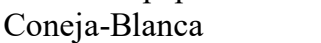 & $\square \square$ & 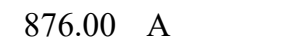 \\
\hline 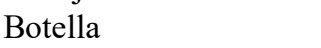 & एण & 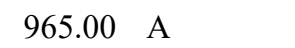 \\
\hline 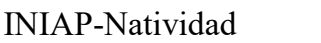 & $\square \square$ & 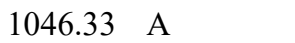 \\
\hline 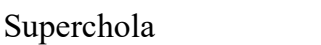 & $\square \square$ & 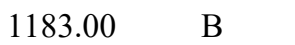 \\
\hline 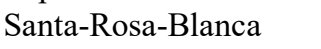 & एण & 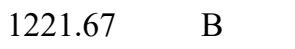 \\
\hline 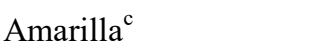 & एण & 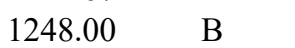 \\
\hline 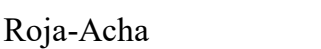 & $\square \square$ & 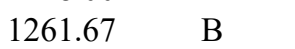 \\
\hline 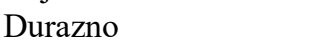 & एण & 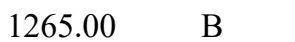 \\
\hline 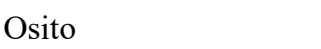 & एण & 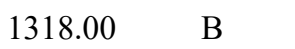 \\
\hline 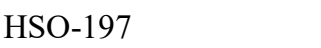 & एण & 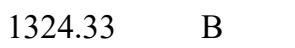 \\
\hline 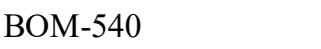 & घण & 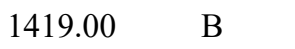 \\
\hline 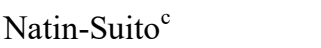 & $\square \square$ & 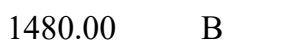 \\
\hline 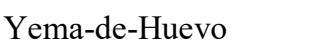 & एण & 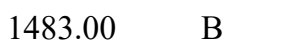 \\
\hline
\end{tabular}




\begin{tabular}{|c|c|c|}
\hline$\square\|\| \|$ & एण & 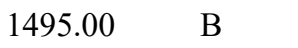 \\
\hline 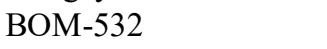 & $\square \square$ & 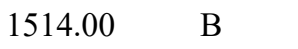 \\
\hline 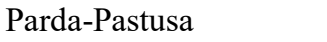 & $\mathrm{II \|}$ & 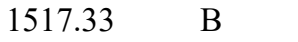 \\
\hline 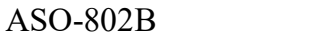 & $\amalg \square$ & $\Pi\|\| \amalg \square$ \\
\hline 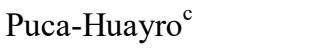 & 11 & $\Pi\|\| \amalg \square$ \\
\hline 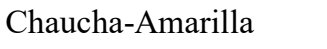 & 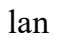 & $\Pi\|\| \square \square$ \\
\hline पाणाயण & $\amalg$ & 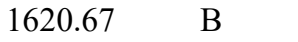 \\
\hline 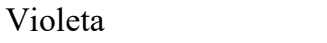 & $\square \square$ & $\Pi \| \Pi \square$ ए \\
\hline पाणाயण & $\square$ & एमाए ए \\
\hline पण口冋س & & $\Pi\|\| \| \square \square$ \\
\hline 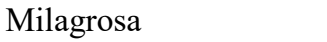 & 1 & \|\|\|\|$\square$ \\
\hline 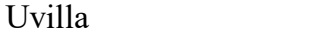 & $\Pi \square$ & 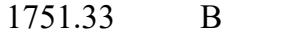 \\
\hline 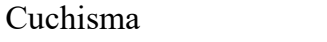 & $\Pi \square$ & 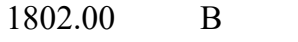 \\
\hline 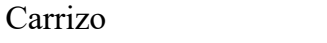 & $\Pi \square$ & ПपПएा ए \\
\hline पाणாயாய & $\square$ & पमापा ए \\
\hline பாடாயாயா & 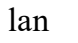 & 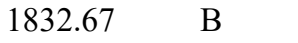 \\
\hline 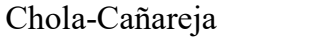 & $\Pi \square$ & 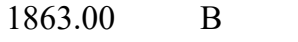 \\
\hline 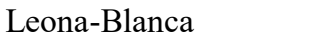 & $\Pi \square$ & आपाप ए \\
\hline 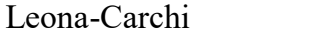 & $\square$ & पП口णा ए \\
\hline 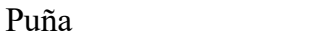 & $\Pi \square$ & 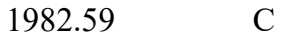 \\
\hline 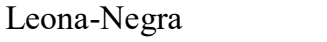 & $\Pi \square$ & 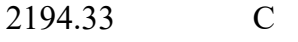 \\
\hline 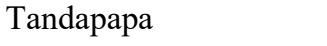 & $\square \square$ & $\square\|\| \square \square \square$ \\
\hline 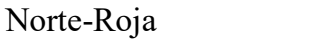 & $\mathbb{1 1}$ & पापए ए \\
\hline 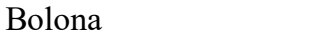 & $\Pi \square$ & एपाप एा \\
\hline 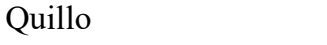 & & 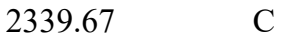 \\
\hline पाmाणm & & 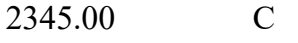 \\
\hline घमणாமாயாயா & 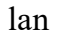 & 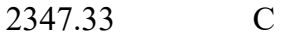 \\
\hline 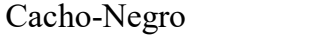 & & $\square \square \| \square \square \square$ \\
\hline 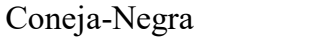 & $\square \square$ & पापा ए ए \\
\hline 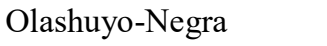 & & पाणा ए प \\
\hline 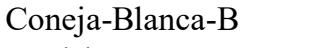 & 10 & 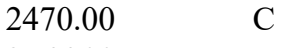 \\
\hline 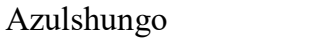 & & पापा एा प \\
\hline 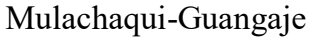 & & 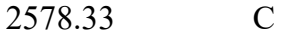 \\
\hline 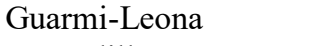 & $\square$ & एमाए एा ए \\
\hline 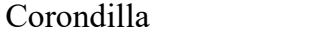 & (1) & 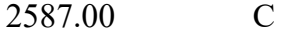 \\
\hline 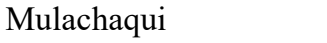 & 1010 & 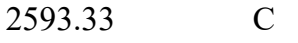 \\
\hline 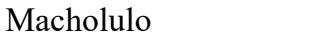 & पाI & 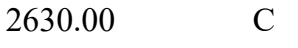 \\
\hline 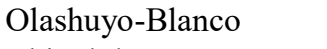 & $\| 1$ & प1Mा ए \\
\hline 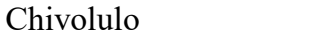 & एा & 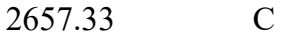 \\
\hline 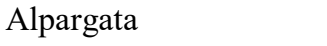 & & पामाए ए ए \\
\hline 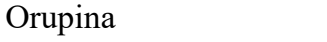 & & 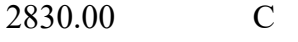 \\
\hline 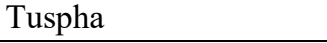 & Шा & 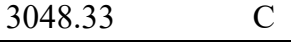 \\
\hline 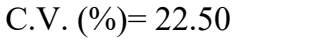 & $\square$ & $\ulcorner\square \quad \square \quad \square$ \\
\hline
\end{tabular}

$\square$ Means followed by the same letter are not significantly different $(\alpha=0.05)$ according to Scott \& Knott test. $\square$

प

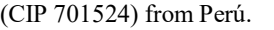




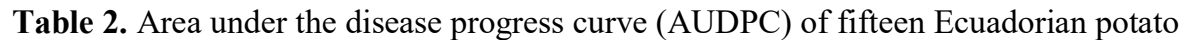

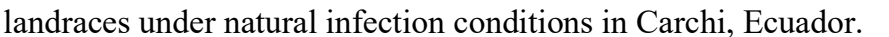

\begin{tabular}{|c|c|}
\hline & $\begin{array}{l}\square \square \square \square \square \\
\square\end{array}$ \\
\hline 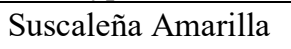 & पाயI $\square \square \square$ \\
\hline III) & $\square\|\| \square \square \square$ \\
\hline & 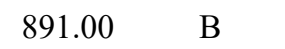 \\
\hline$\| 1 \mathrm{~mW}$ & 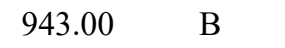 \\
\hline IIس & पाए ए एव \\
\hline III) & 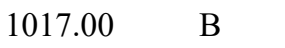 \\
\hline $\mathrm{m}$ & 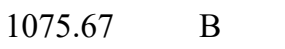 \\
\hline Imس & $\square \| \Pi \square \square \square \square \square$ \\
\hline पण口णाய & 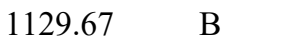 \\
\hline $\mathrm{im} \mathbf{m}$ & पा\|ा ए \\
\hline 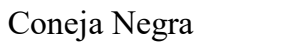 & 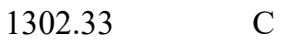 \\
\hline 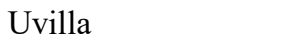 & पा\|ा ए \\
\hline पाणाणाण & पा\|ा ए \\
\hline एाm & पा\|ा ए \\
\hline Iण口س & 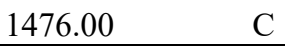 \\
\hline 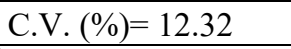 & $\sqsubset \square \quad \square$ \\
\hline
\end{tabular}

Means followed by the same letter are not significantly different $(\alpha=0.05)$ according to Scott $\&$ Knott test. $\square$

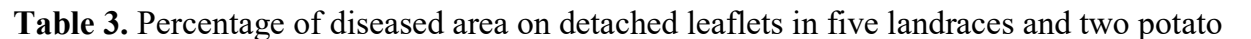

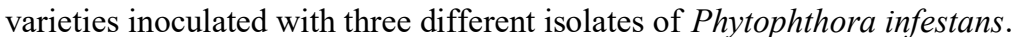

\begin{tabular}{|c|c|c|c|c|c|c|c|c|c|c|}
\hline \multirow[t]{2}{*}{ 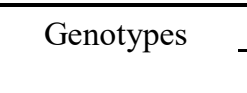 } & \multicolumn{10}{|c|}{ 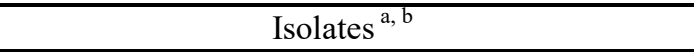 } \\
\hline & \multicolumn{3}{|c|}{ पणणा } & \multicolumn{3}{|c|}{ 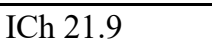 } & \multicolumn{4}{|l|}{ 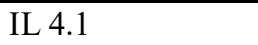 } \\
\hline 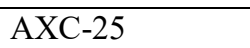 & 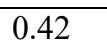 & $\square[$ & $\square$ & 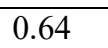 & $\square[$ & $\square$ & 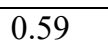 & $\square$ & $\square[$ & $\square$ \\
\hline$\square \square \square\|\| \|^{\natural} \square$ & $\square \square \square$ & $\square[$ & $\square$ & $\square \square \square$ & $\square[$ & $\square$ & $\square \square$ & $\square[$ & $\square$ & $\square$ \\
\hline प्णाणाய & $\square \square \square$ & $\square[$ & $\square$ & $\square \square \square$ & $\square$ & $\square \square$ & $\square \square \square$ & $\square$ & $\square \square$ & $\square$ \\
\hline 四四 & $\square \square \square$ & $\square$ & $\square[$ & $\square \square \square$ & $\square[$ & $\square$ & $\square \square \square$ & $\square[$ & $\square$ & $\square$ \\
\hline$\square \square \square \square \square ा \Pi \square$ & $\square \square \square$ & $\square$ & $\square[$ & $\square \square \square$ & $\square$ & $\square \square$ & $\square \square$ & $\square$ & $\square$ & $\square[$ \\
\hline 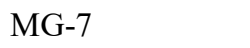 & $\square \square \square$ & $\square$ & $\square[$ & $\square \square \square$ & $\square$ & $\square \square$ & $\square \square \square$ & $\square$ & $\square$ & $\square[$ \\
\hline 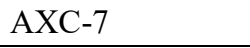 & $\square[1 \square$ & एा & $\square[$ & $\square \square$ & $\square$ & $\square \square$ & 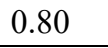 & $\square$ & $\square$ & $\square[$ \\
\hline 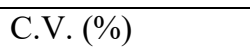 & $\square \mid \square \square$ & एा] & एा & $\square \mid \Pi \square$ & $\square$ & [ & $\square \| \square$ & $\square$ & $\square$ & $\square$ \\
\hline
\end{tabular}

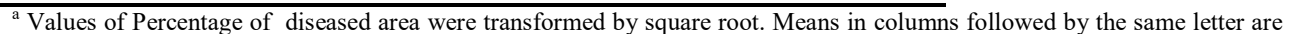
not significantly different $(\alpha=0.05)$ according to Scott $\&$ Knott test. $\square$

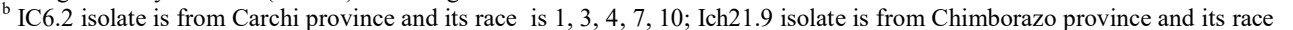

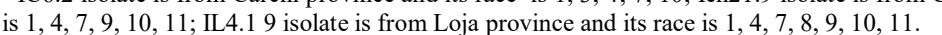

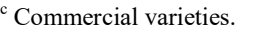

$\square$ 


\title{
Chapter 5
}

\section{Farmers' perception of Ecuadorian potato landraces}

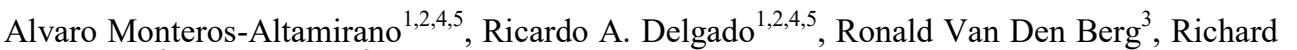

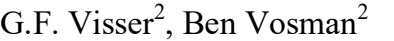

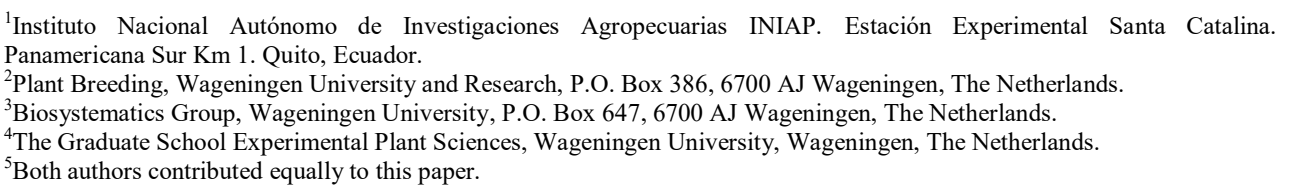

\section{Submitted for publication}

$\square$

\begin{abstract}

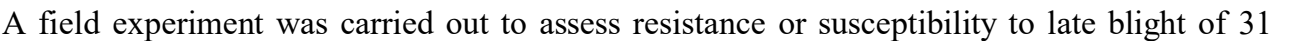

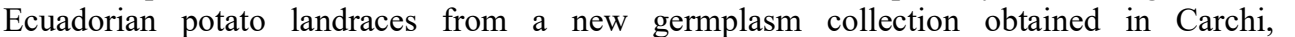

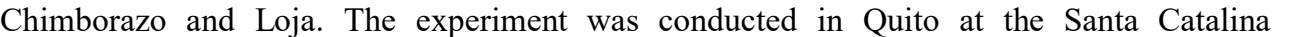

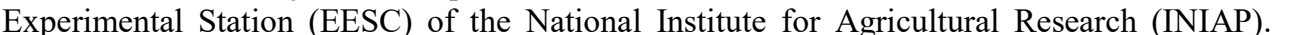

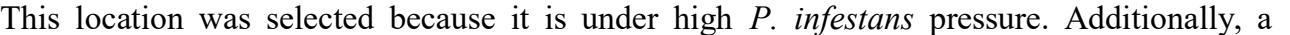

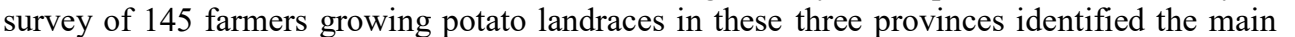

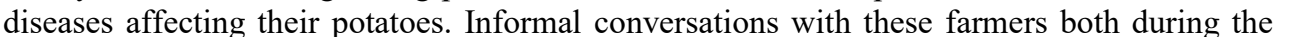

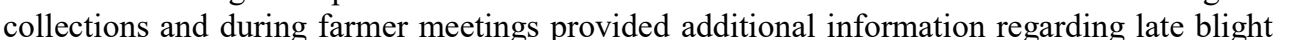

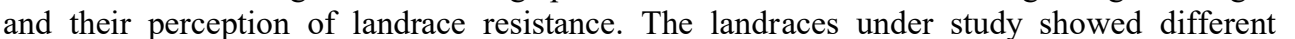

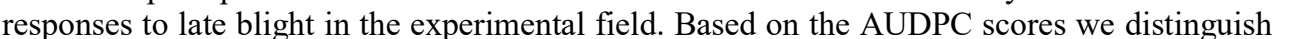

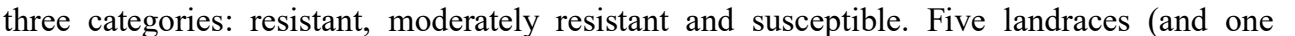

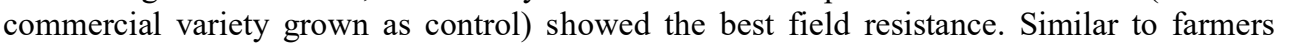

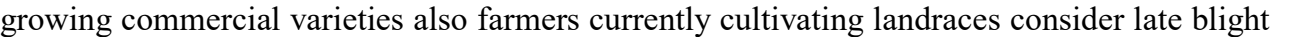

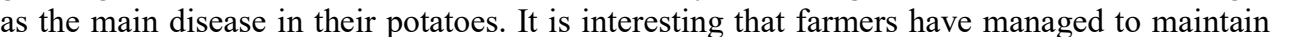

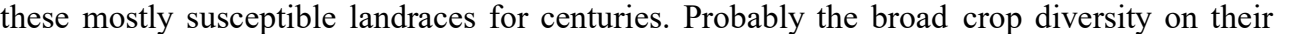

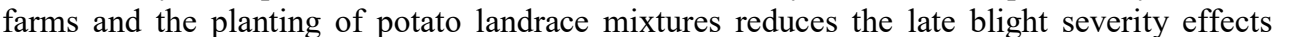

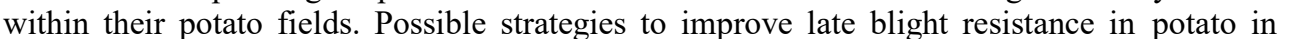

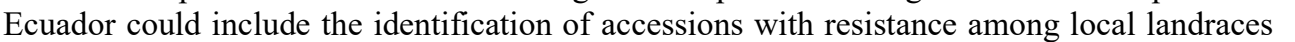

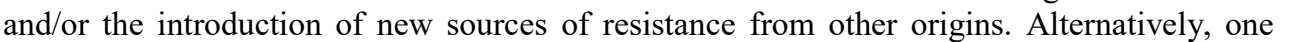

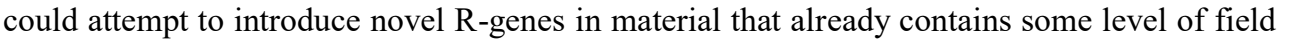

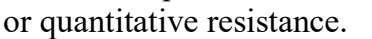

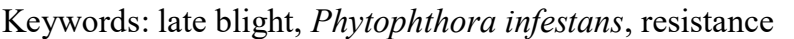




\section{Introduction}

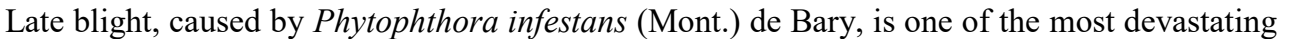

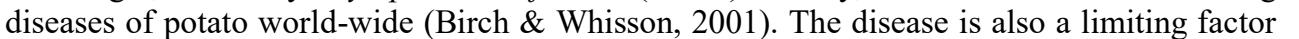

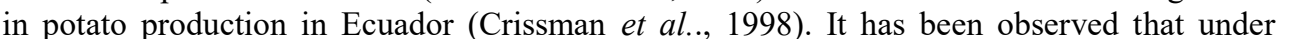

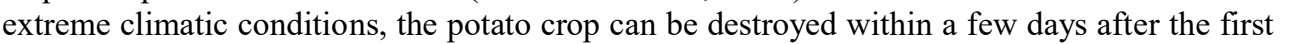

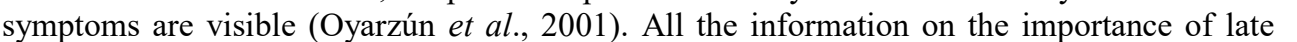

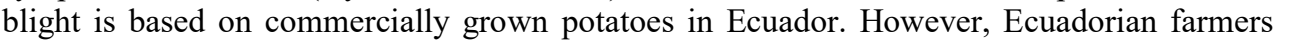

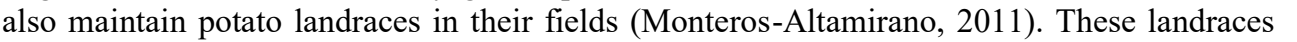

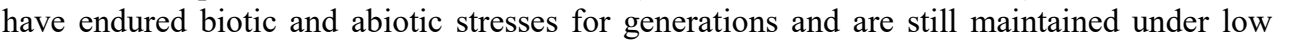

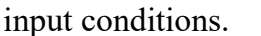

$\square$

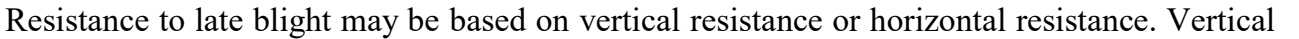

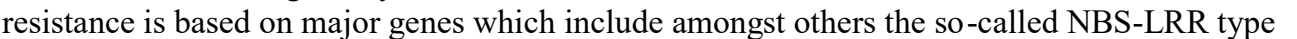

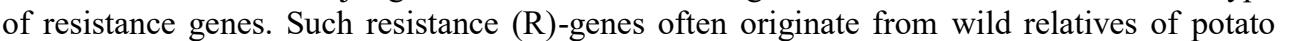

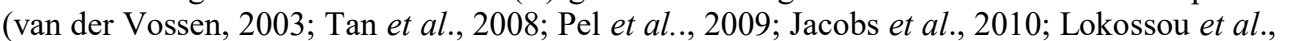

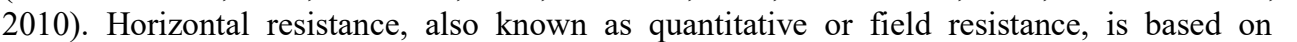

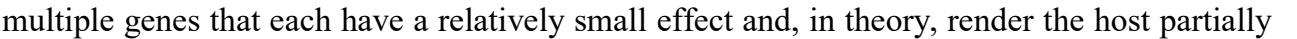

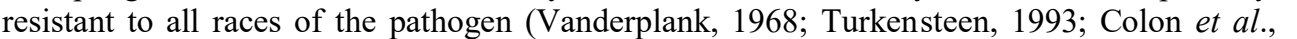

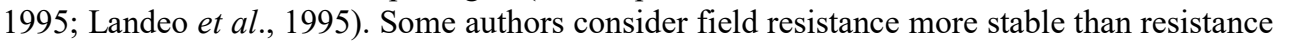

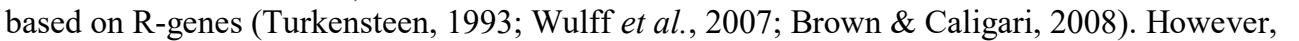

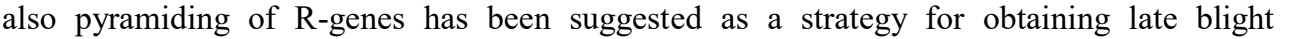

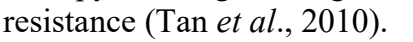

$\square$

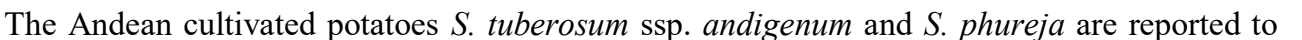

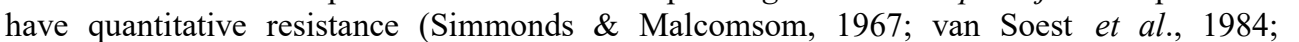

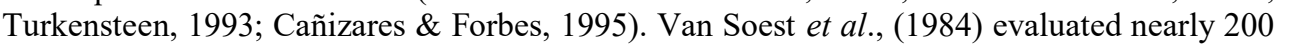

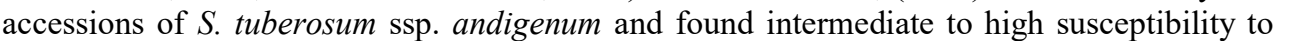

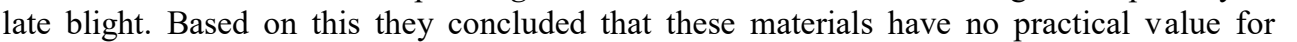

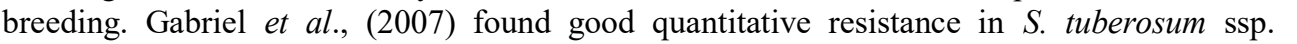

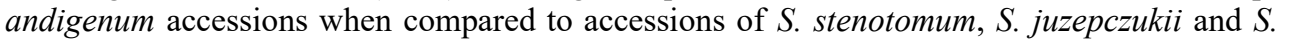

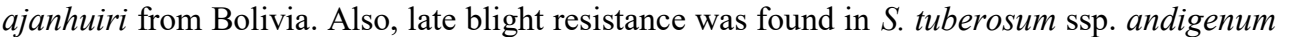

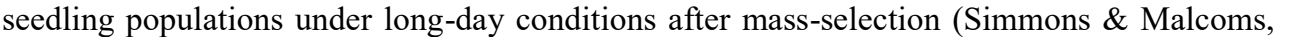

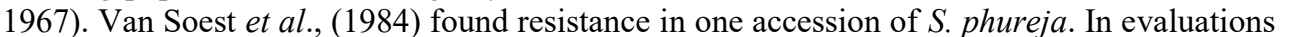

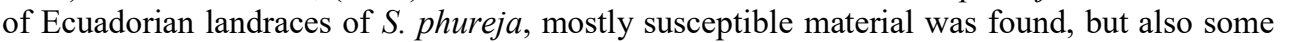

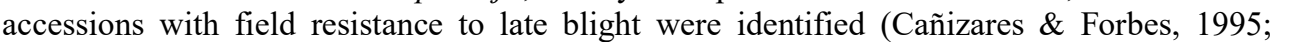

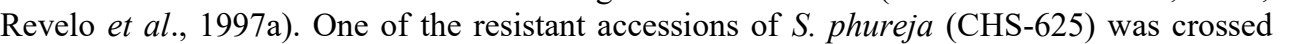

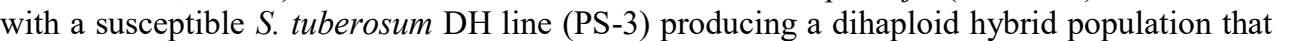

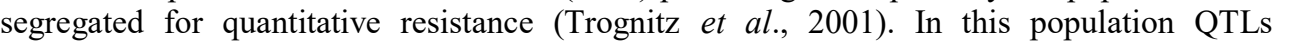

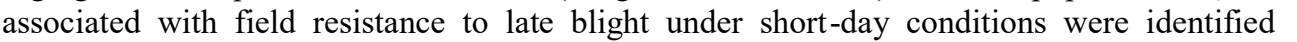

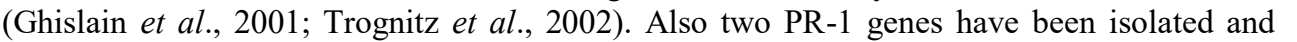

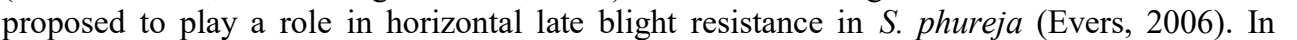

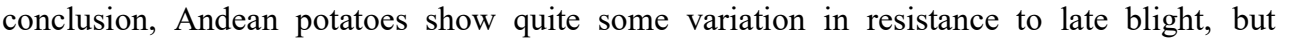

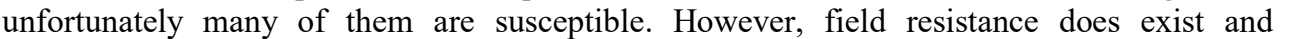

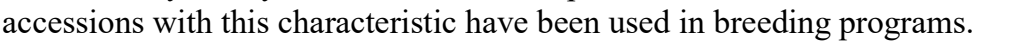




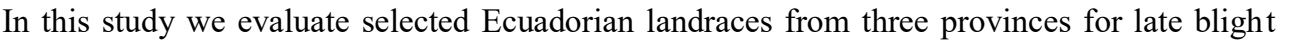
resistance under natural conditions. We connect our evaluation with the farmers' perception

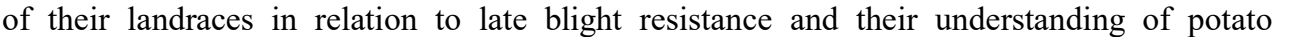

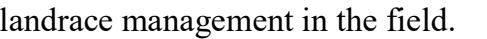

\section{Materials and methods}

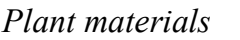

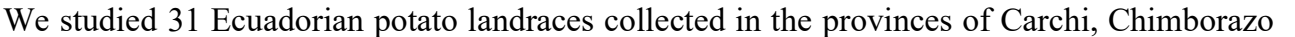

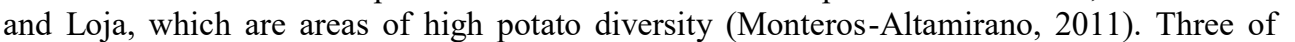

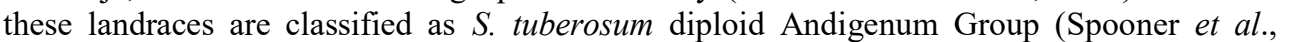

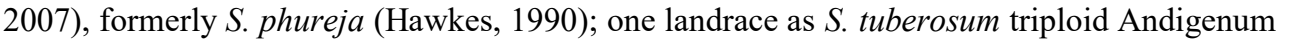

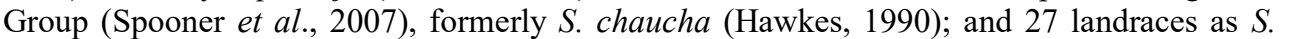

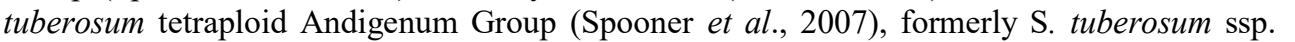

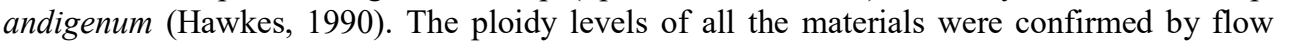

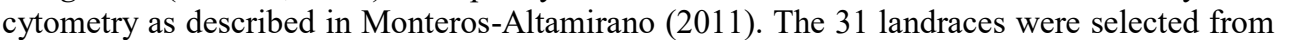

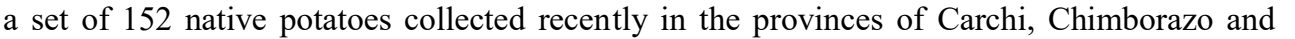

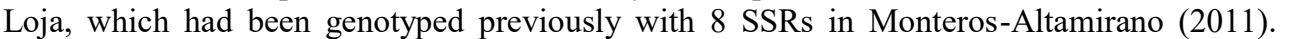

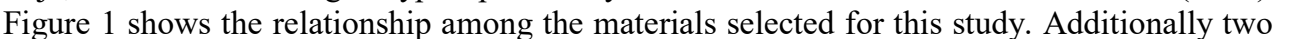

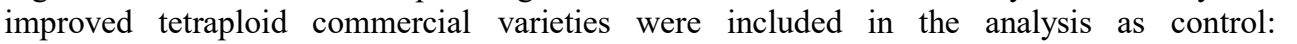
'Superchola' and 'I Fripapa'. 


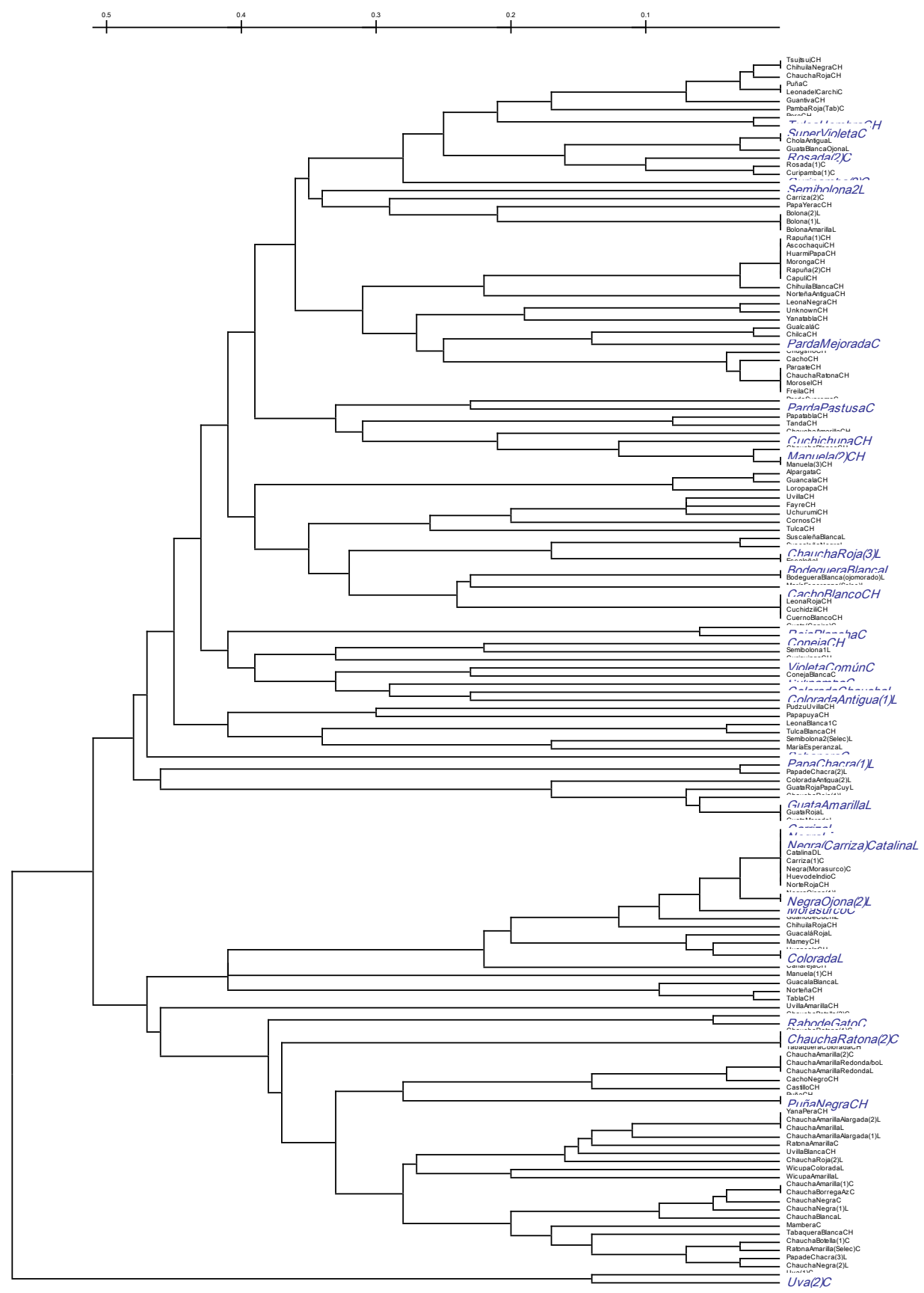

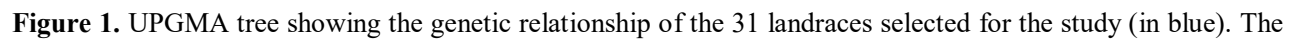

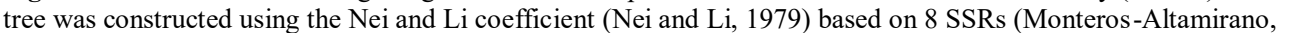

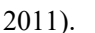




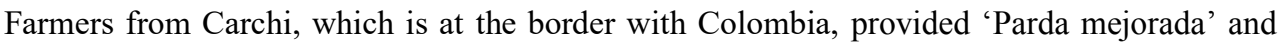
'Parda pastusa' as landraces. However, there are also Colombian commercial varieties under these names. According to Nustez (2010) the Colombian 'Parda pastusa', was produced by a

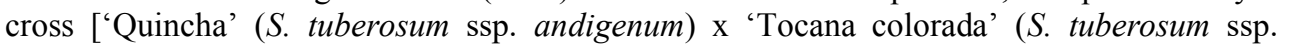
$\square|\Pi| \backslash \square)$ ]. The material of 'Parda pastusa' used in our study was triploid and we consider this material as a landrace. We could not get additional information on 'Parda mejorada'. 'Uva' wa

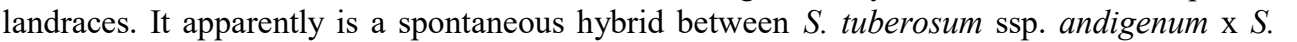

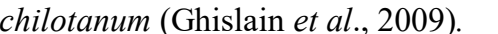

$\square$

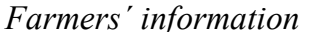

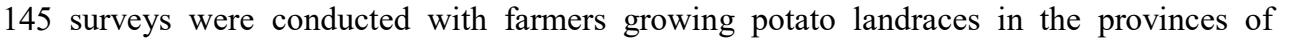

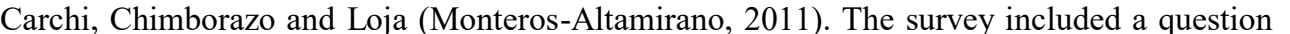

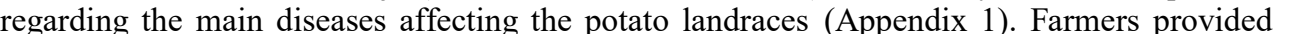

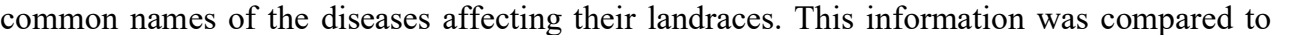

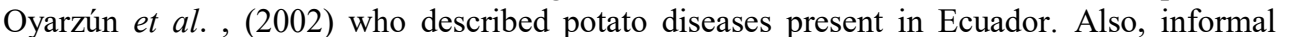

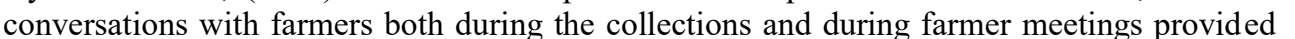

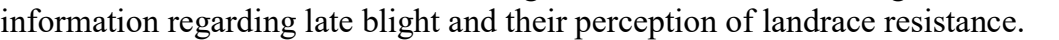

$\square$

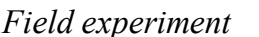

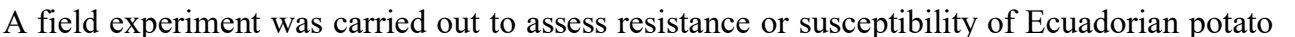

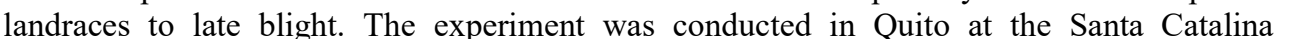

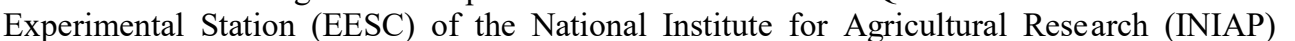
located at 3050 m.a.s.l, Longitude: $78^{\circ} 33^{\prime} 15^{\prime \prime}$ and Latitude: $00^{\circ} 22^{\prime} 4^{\prime \prime} \mathrm{S}$. The average annual

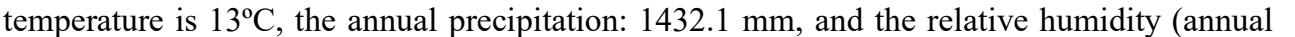

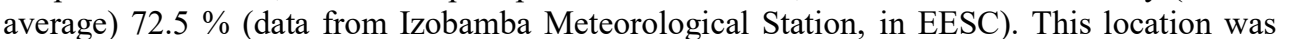

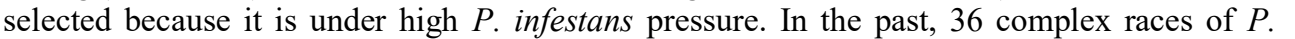

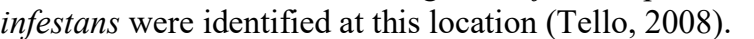

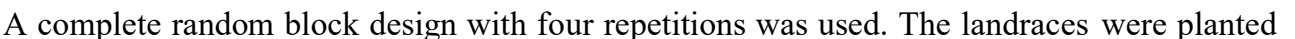

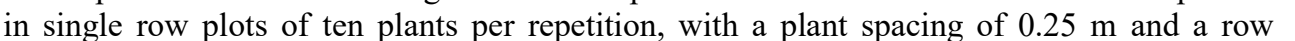

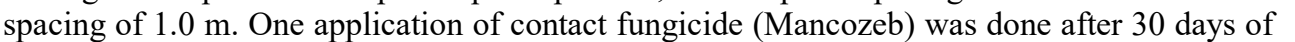

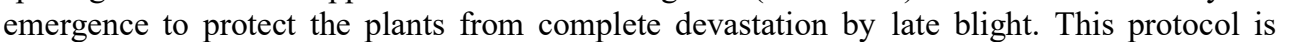

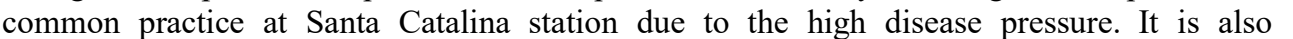

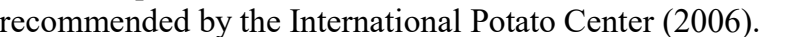

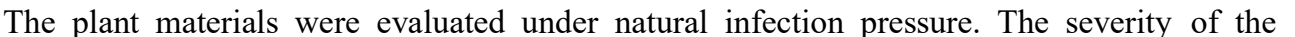

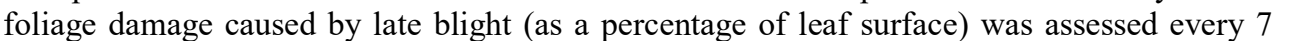

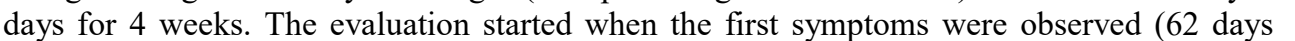

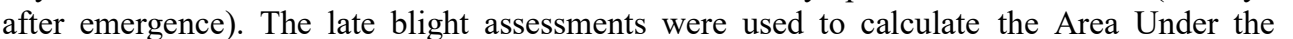

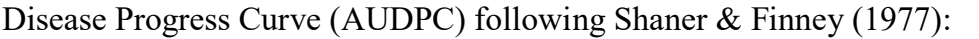

핌

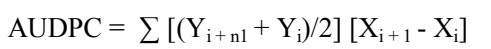




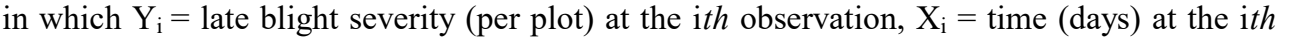

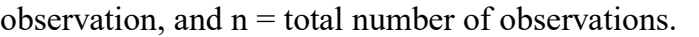

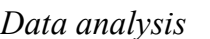

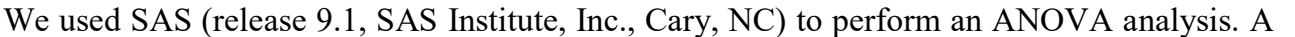

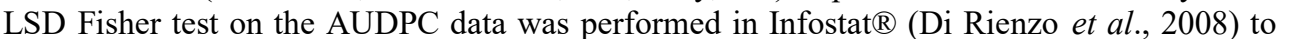

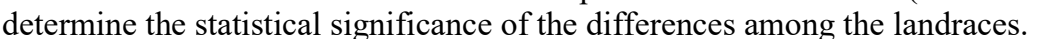

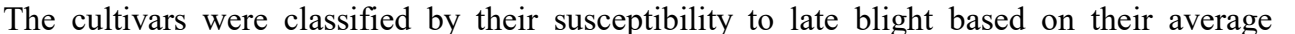

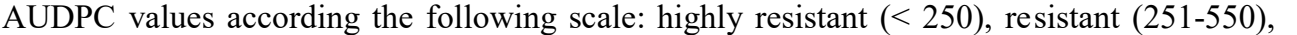

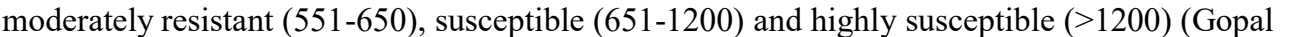

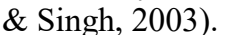

\section{Results $\square$}

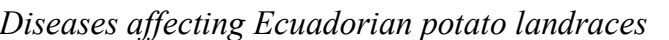

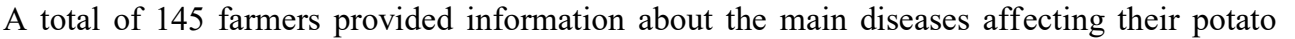

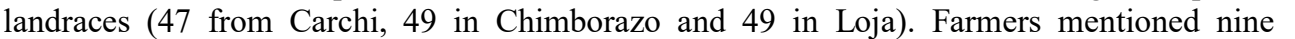

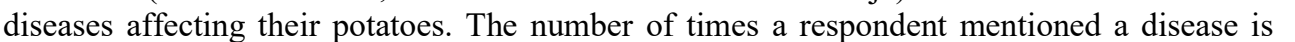

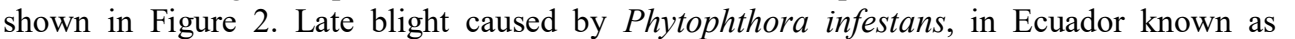
'Lancha', was most frequently mentioned in the three areas. The second important disease in Carchi was 'Lanosa' $\square \square \square\|\square\| \Pi$ sp.) and in Chimborazo and Loja: 'Pudrición de la raíz',

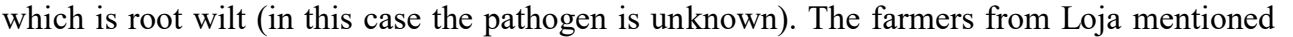

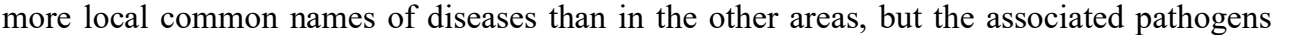
are unknown. These diseases were grouped under the category "Other". 

$\square$ 1. Phytophthora 2. Rosellinia
日 3. Nematodes ②. Erwinia
5. Oidium
6. Puccinia
$\square$ 7. Rhizoctonia
8. Root wilt (n.d.)
9.Virus
10. 10 ther

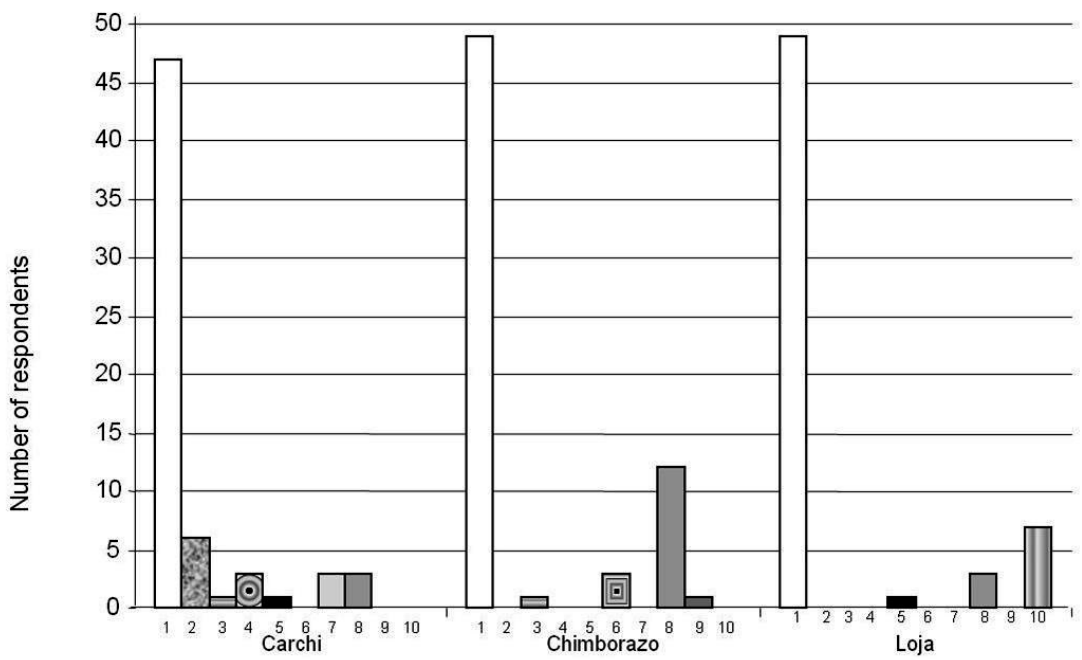

Areas where the survey was conducted

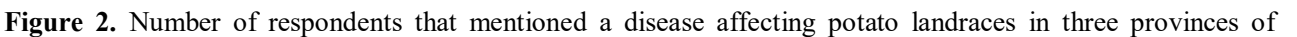

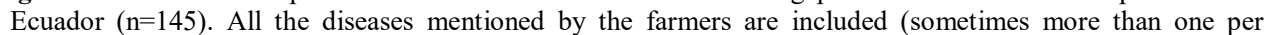

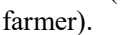

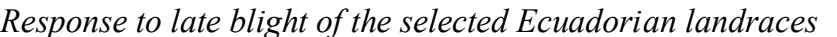

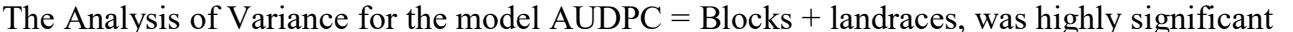

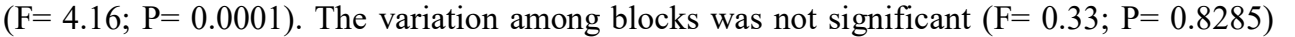

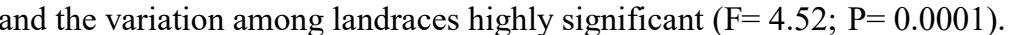

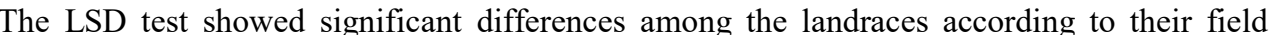

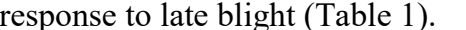




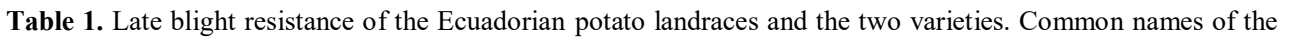

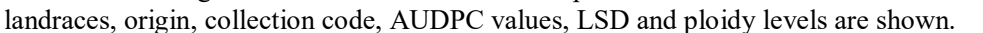

\begin{tabular}{|c|c|c|c|c|c|c|c|}
\hline Landrace & Province & Code & Ploidy & & $\begin{array}{c}\text { AUDPC } \\
\text { (average) }\end{array}$ & LSD $^{*}$ & $\begin{array}{c}\text { Late blight } \\
\text { reaction }\end{array}$ \\
\hline$\square \square$ & पणाणाप & $\square\|\| \square$ & $\square$ & $\square$ & $\square \square$ & $\square \square$ & $\square \square$ \\
\hline पणाणणाणाणा & 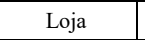 & 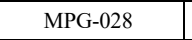 & $\square$ & $\square$ & $\square \square$ & $\square \square \square$ & $\square \square$ \\
\hline 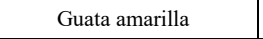 & $\square \square ण ा$ & प्षणाए & $\square$ & $\square$ & $\square 11$ & $\square \square \square \square$ & $\square \square$ \\
\hline पपाणा & पणापणाणा & पाषमणपाण & $\square$ & $\square$ & $\square 1 \square$ & 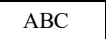 & $\square \square$ \\
\hline$\square \square 1111010111$ & पपणाणाप & प्राणा। & $\square \square$ & $\square$ & $\square 11$ & $\square \square \square \square$ & $\square \square$ \\
\hline 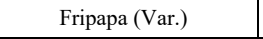 & $\square$ & $\square$ & $\square \square$ & $\square$ & $\square 11$ & $\square \square \square \square$ & $\square \square$ \\
\hline$\square 111010101010 \square \square$ & $\square$ & $\square$ & $\square$ & $\square$ & $\square 11$ & $\square \square \square \square \square$ & $\square \square \square$ \\
\hline 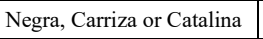 & $\square \square \square$ & 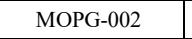 & $\square$ & $\square$ & $\square 11$ & $\square \square \square \square$ & $\square \square \square$ \\
\hline पाणमणनणमाण & $\square \square ण 10$ & प्राणा। & $\square \square$ & $\square$ & $\square 11$ & $\square \square \square \square$ & $\square \square \square$ \\
\hline पणमाणाणए & पपणाणा & पमपणाए & $\square$ & $\square$ & $\square 11$ & 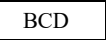 & $\square \square \square$ \\
\hline पपापापाए & 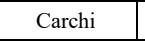 & पवपषणाए & $\square$ & $\square$ & $\square 11$ & $\square \square \square \square \square$ & $\square \square \square$ \\
\hline 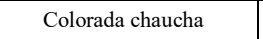 & 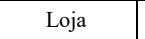 & 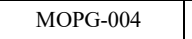 & $\square$ & $\square$ & $\square 11$ & 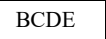 & $\square$ \\
\hline पाणाणाणाए & 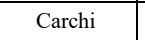 & पवणाए & $\square$ & $\square$ & $\square 11$ & 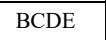 & $\square$ \\
\hline$\square \square ण \| ण \square$ & पवाणाप & पमपणाए & $\square$ & $\square$ & $\square 11$ & \begin{tabular}{l|l|l|} 
\\
\end{tabular} & $\square$ \\
\hline पाणणाणाण & पणापणाणा & 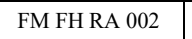 & $\square$ & $\square$ & $\square 1 \square$ & $\square \square \square \square \square \square$ & $\square$ \\
\hline पमाणाणाणाप & $\square \square ण 10$ & पवाणा & $\square$ & $\square$ & $\square 11$ & 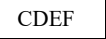 & $\square$ \\
\hline$\square 101010101011$ & पपणाणा & पपरणाण & $\square \square$ & $\square$ & $\square 11$ & $\square \square \square \square \square$ & $\square$ \\
\hline 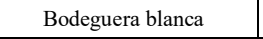 & $\square \square ण \square$ & 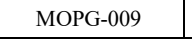 & $\square \square$ & $\square$ & $\square 11$ & $\square \square \square \square \square$ & $\square$ \\
\hline पणमाणा & पवाणा & प्षणापए & $\square$ & $\square$ & $\square 11$ & $\square \square \square \square$ & $\square$ \\
\hline पणणा & $\square \square ण \square$ & पवणाण & $\square \square$ & $\square$ & $\square 11$ & $\square \square \square \square \square$ & $\square$ \\
\hline पवणाणाए & 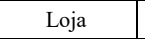 & पमपणाणा & $\square$ & $\square$ & $\square 11$ & 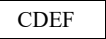 & $\square$ \\
\hline 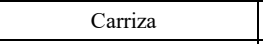 & पवापा & पमाणा। & $\square \square$ & 5 & $\square 11$ & \begin{tabular}{|l|l|l|} 
\\
\end{tabular} & $\square$ \\
\hline 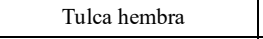 & $\square \square \square \square ण 111$ & पमपषण & $\square$ & $\square$ & $\square 1$ & $\square \square \square \square \square$ & $\square$ \\
\hline$\square ण \Pi 1 \square \square \square$ & पपणाणाप & पपमणा। & $\square \square$ & $\square$ & $\square 11$ & $\square \square \square \square$ & $\square$ \\
\hline पणमणणाणमाणा & $\square \square ण ा$ & पषणाण & $\square$ & $\square$ & $\square 11$ & $\square \square \square \square$ & $\square$ \\
\hline पणाणाणाएा & प्णाणाप & प्माणा। & $\square$ & $\square$ & $\square 1$ & $\square \square \square \square$ & $\square$ \\
\hline पालापाणणा & $\square \square \mathrm{III}$ & पवाणाए & $\square$ & $\square$ & $\square 11$ & $\square \square \square \square$ & $\square$ \\
\hline 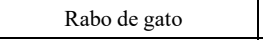 & पपणाणाप & $\square \square \square म 11$ & $\square \square$ & $\square$ & $\square 11$ & $\square \square \square \square$ & $\square$ \\
\hline$\square \square 1 ण \square$ & पणापणाणा & पवपष्म & $\square \square$ & $\square$ & $\square 11$ & $\square \square \square \square$ & $\square$ \\
\hline पपणाए & पवणाण & पमपणा। & $\square$ & $\square$ & $\square 11$ & $\square \square \square \square$ & $\square$ \\
\hline पमापाणा1प & पवापणाण1 & 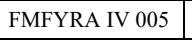 & $\square \square$ & $\square$ & $\square 111$ & $\square \square \square$ & $\square$ \\
\hline पणा1णाणाए & पणापणाणा & पषणपणाप & $\square$ & $\square$ & $\square 11$ & $\square \square \square$ & $\square$ \\
\hline$\square 111110$ & 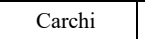 & पवाणा & $\square \square$ & $\square$ & $\square 11$ & $\square \square$ & $\square$ \\
\hline
\end{tabular}

* Different letters indicate significant difference at $\alpha=0.05$.

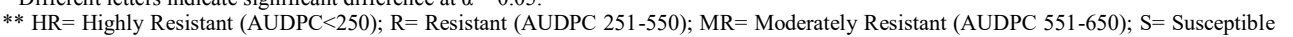

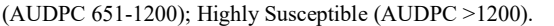

$\square$

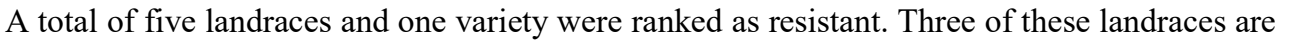

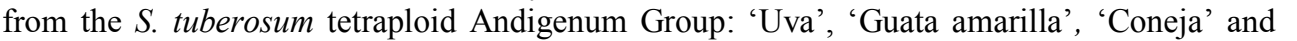

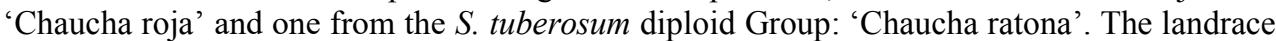

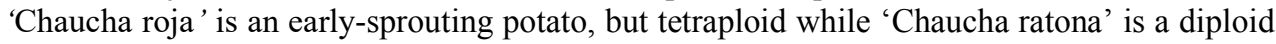
$\square[\| \mid$ sprouting landrace. The landrace 'Uva' performed the best since it had the lowest

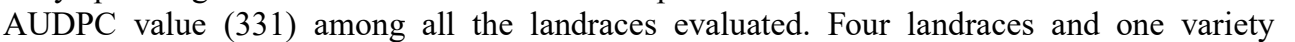
(Superchola) were moderately susceptible. These landraces include: 'Negra $\square \square\|\| \|$ Catalina', 'Super violeta', 'Violeta común', 'Curipamba'. Twenty two of the landraces were susceptible $\square$ 
पा

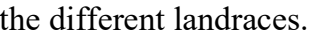

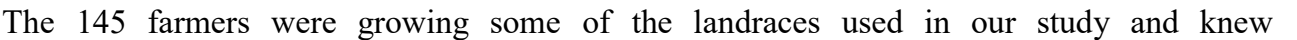

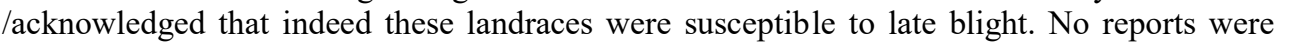

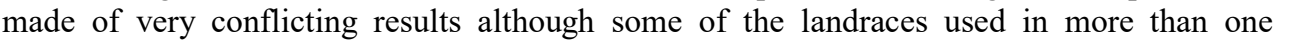

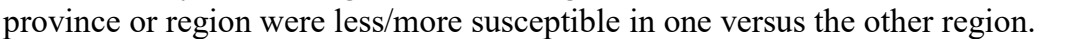

$\square$

\section{Discussion}

$\square$

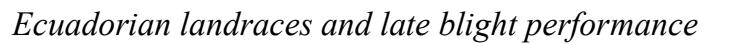

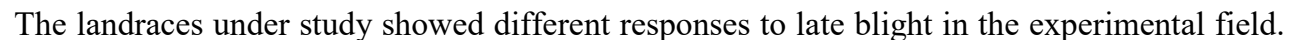

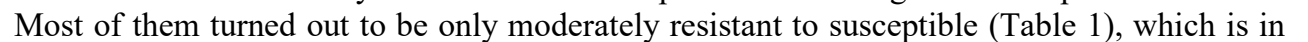

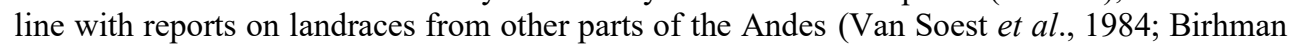

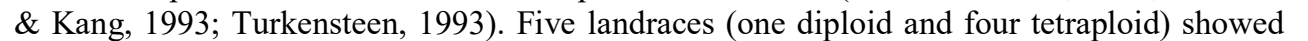

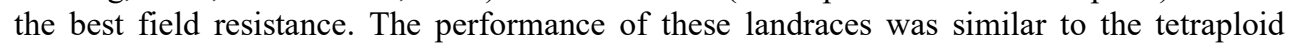
variety 'IFripapa', which is a leading v

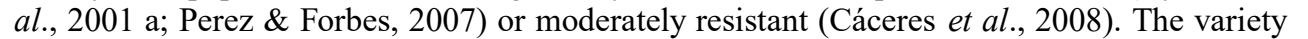
'Superchola' is believed to be susceptible, but was not significantly different from the most एवापातandraces in our field experiment. The landrace 'Uva' performed best and is believed

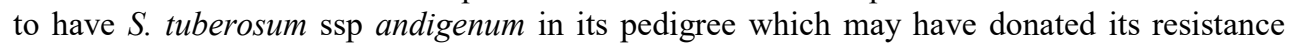

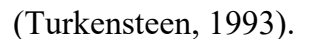

\section{$\square$}

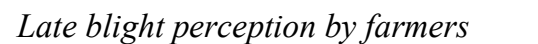

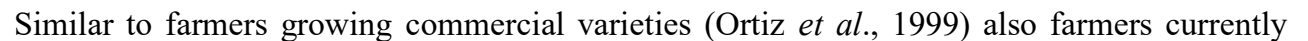

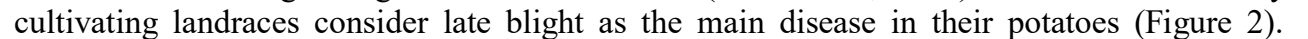

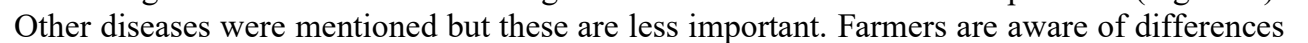

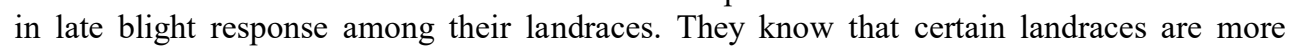
resistant or susceptible than others. For example, 'Sulipamba' is considered susceptible by the farmers, which was confirmed in our field experiment (Table 1). Similarly, 'Uva' was

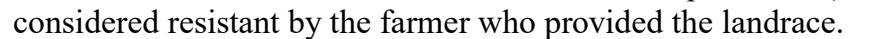

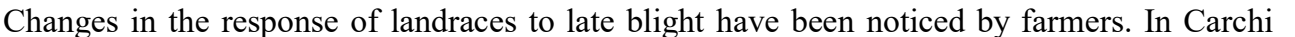
farmers mentioned that 'Violeta', 'Curipamba' and 'Morasurco' were the more resistant

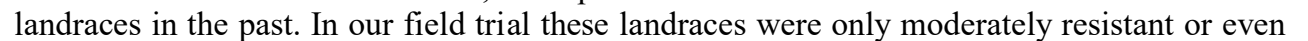

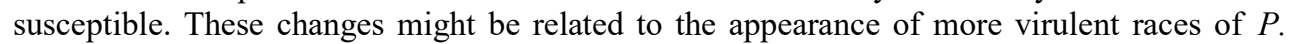

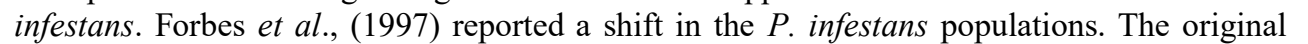

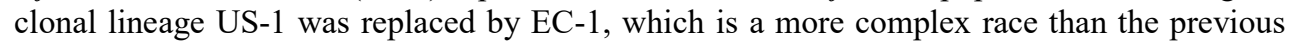
$\square 1 \mathrm{~W}$

$\square$

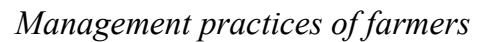

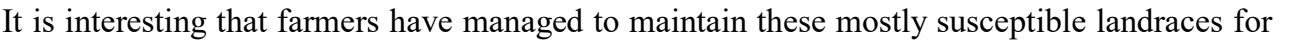

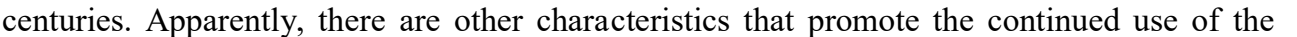




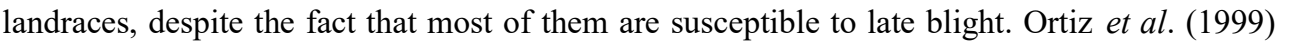

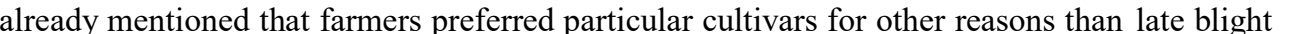

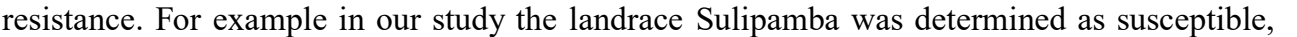

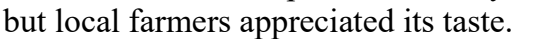

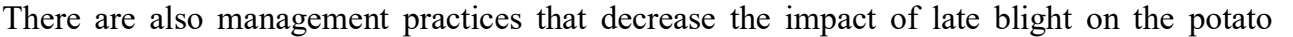

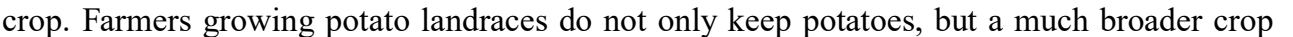

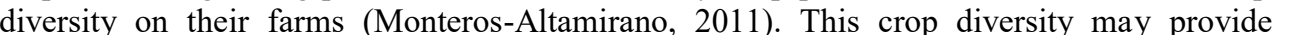

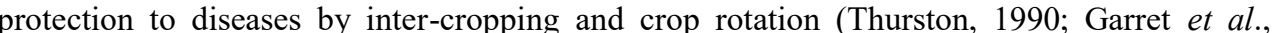
2001). An example is the susceptible landrace 'Papa de chacra', which is grown within corn

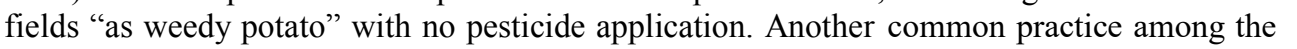

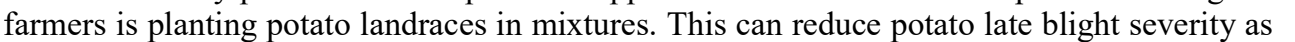

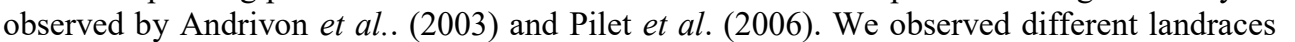

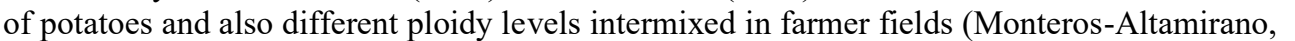
$\square 1 \| \mathbb{1 0}$

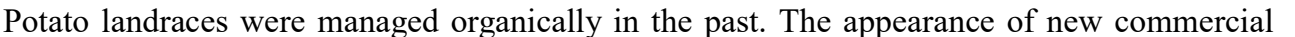
cultivars e.g. 'Superchola' and 'IFripapa' has brought new management practices to the

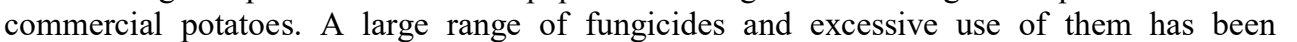

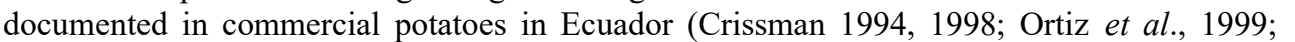

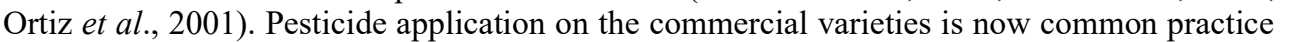

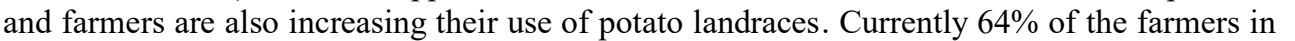

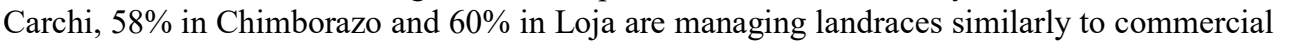

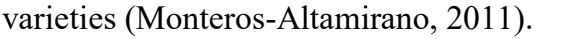

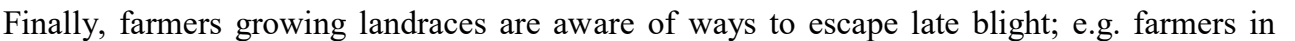

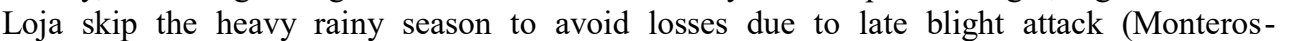

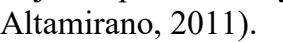

$\square$

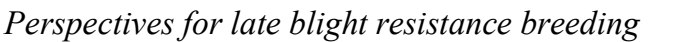

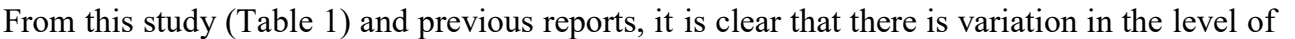

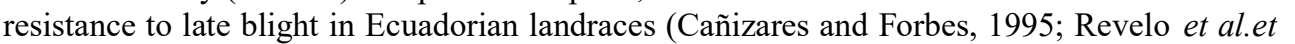

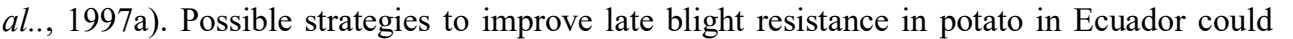

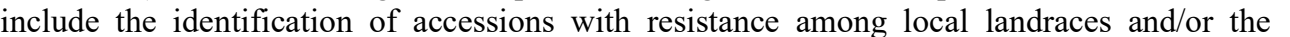

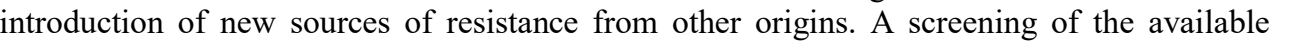

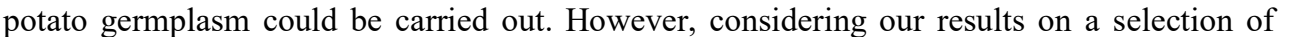

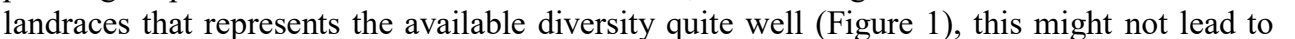

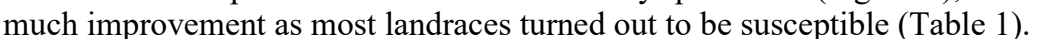

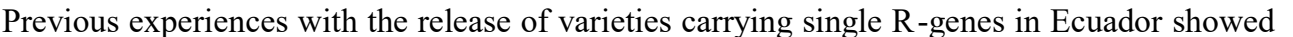

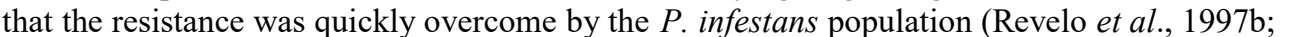

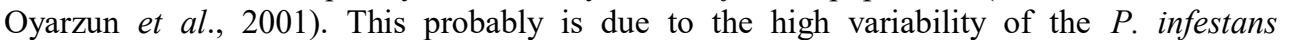

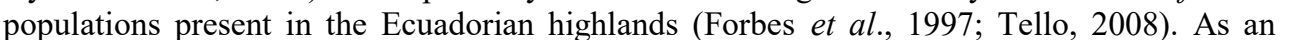

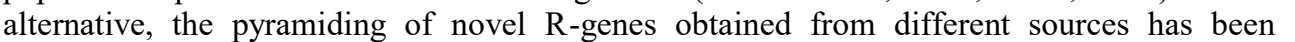

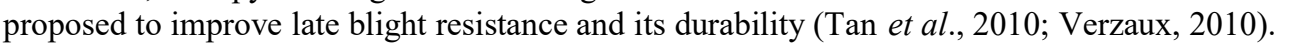

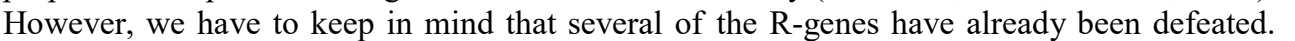

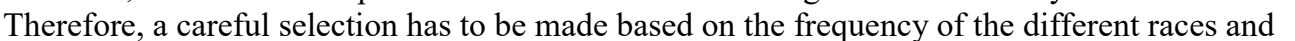

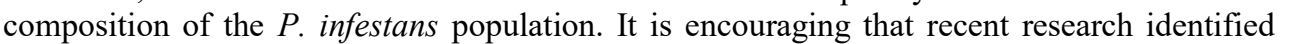

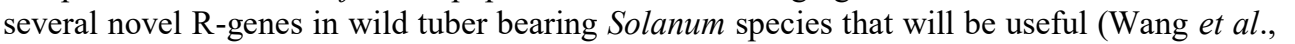




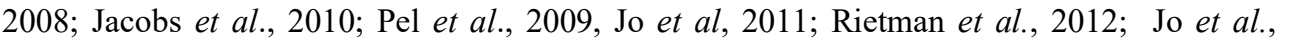

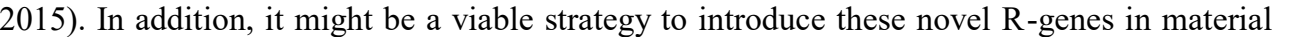

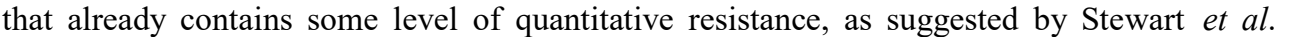

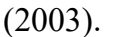

\section{$\square$}

\section{Acknowledgments}

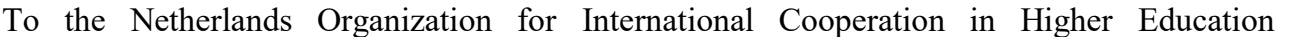

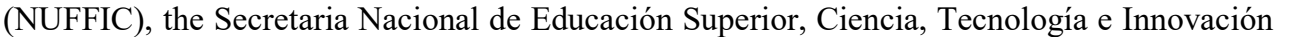

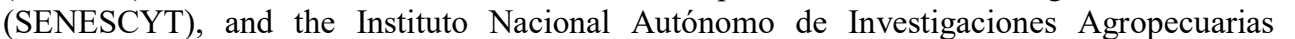

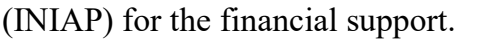

$\square$

\section{Literature cited}

$\square$

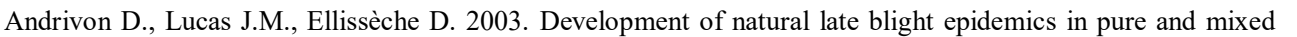

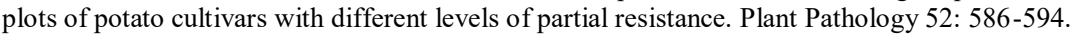
$\square$

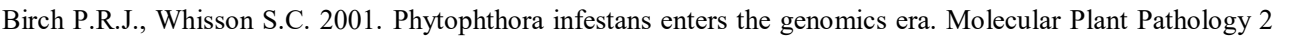
एवाणाएणाए

$\square$

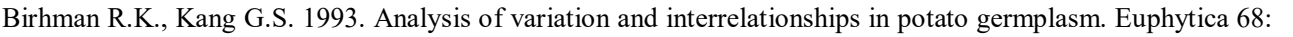
पाणाप

$\square$

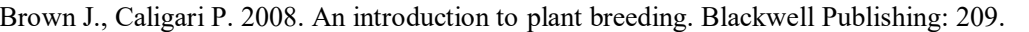

$\square$

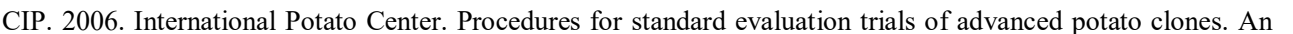

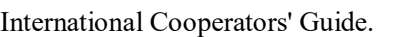

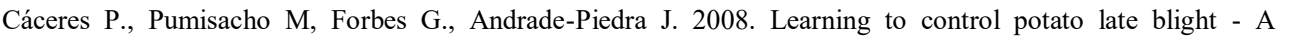
facilitator's guide.

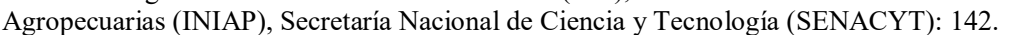
$\square$

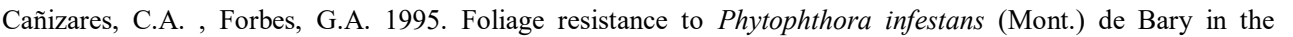

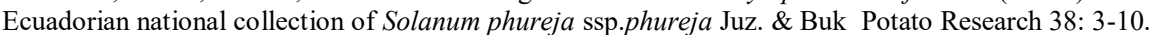
$\square$

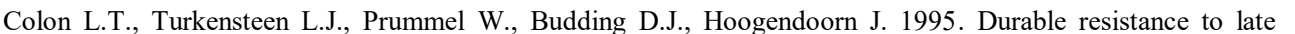

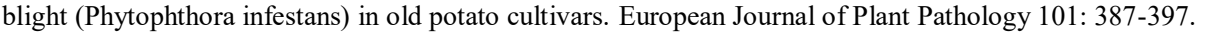
$\square$

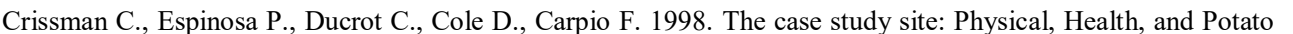

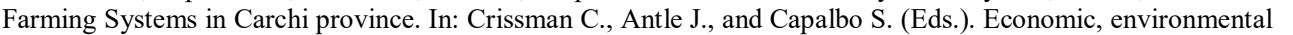

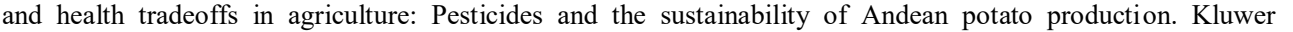

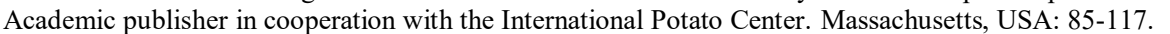
$\square$

प

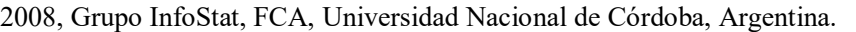
$\square$

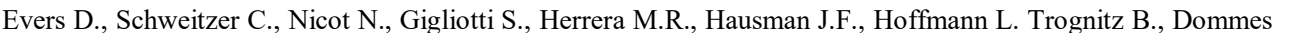
ए

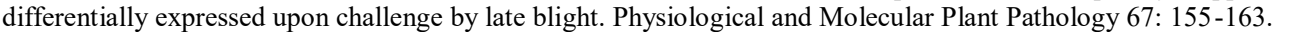
$\square$

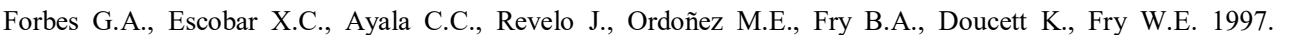

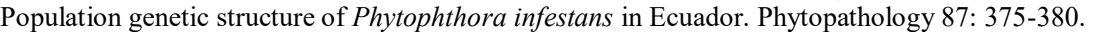

$\square$ 


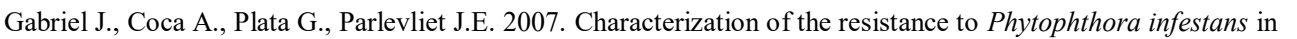

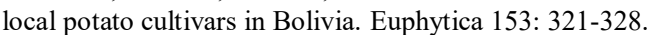

$\square$

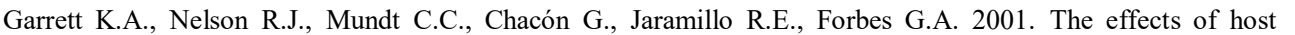

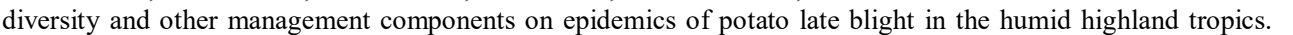

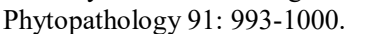

$\square$

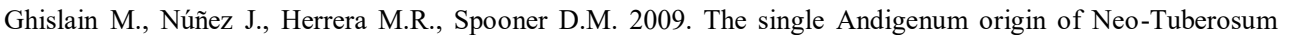

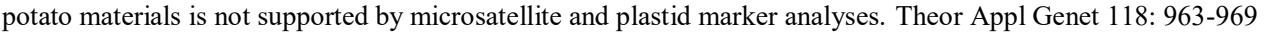
$\square$

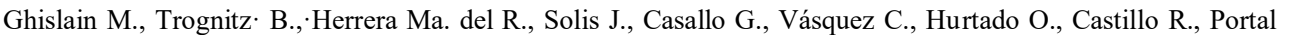

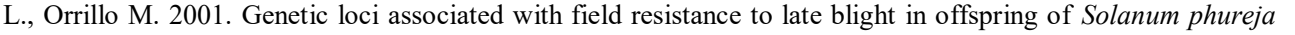

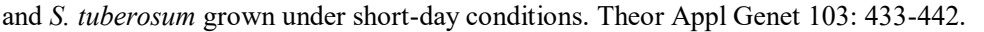
$\square$

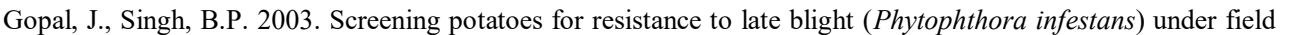

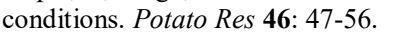

$\square$

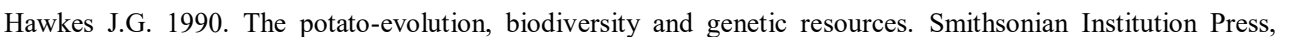

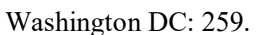

$\square$

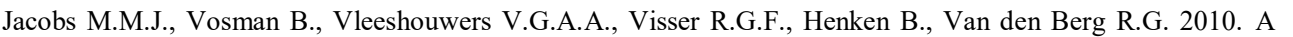

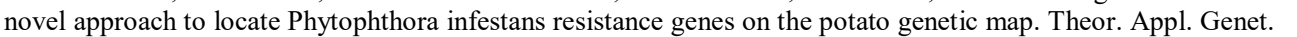
पाणाणमाणा

$\square$

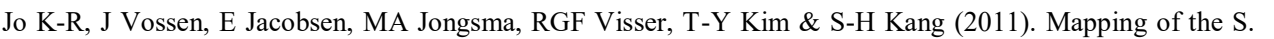

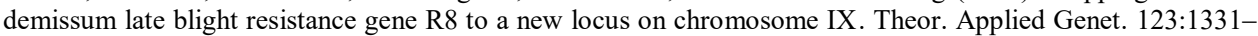
एणाए

$\square$

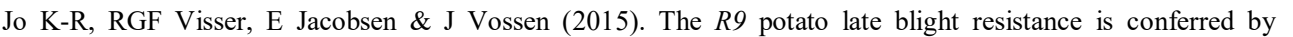

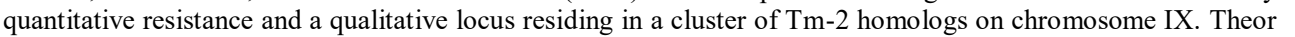

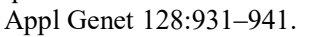

$\square$

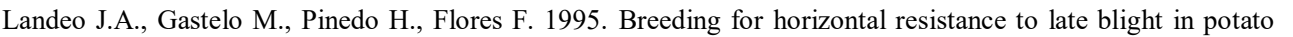

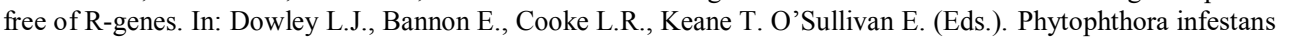

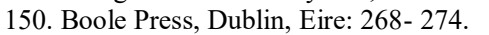
$\square$

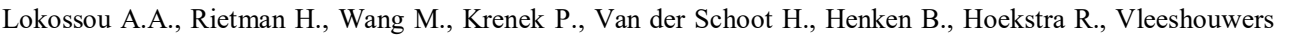
:

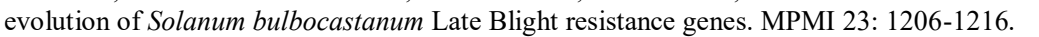
$\square$

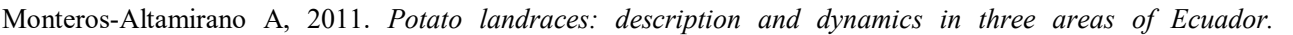

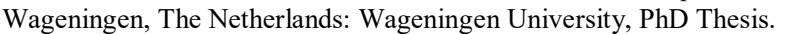

$\square$

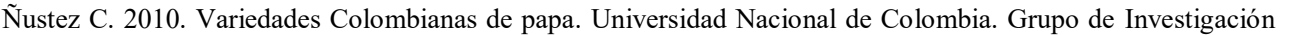

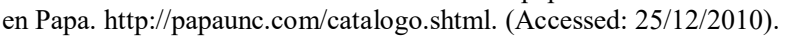

$\square$

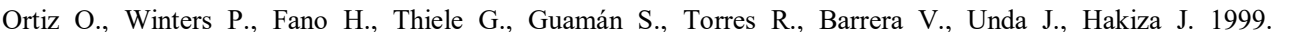
Understanding Farmer's response to late blight: Evidence from Peru, Boli

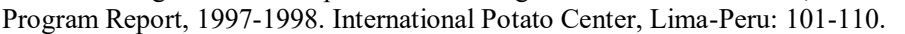
$\square$

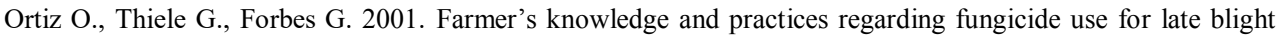

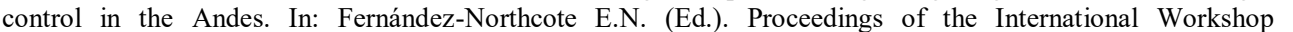

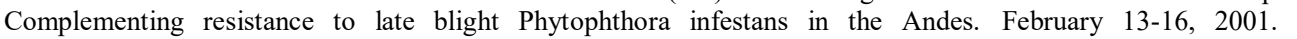

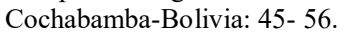

$\square$

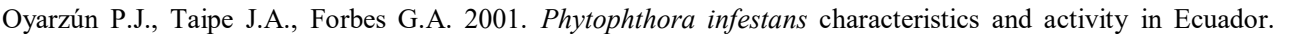

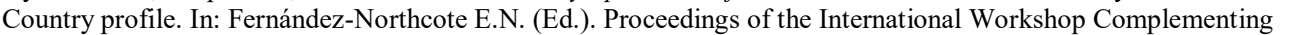

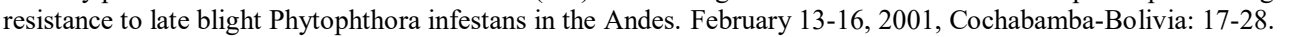
$\square$ 


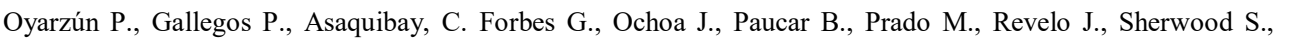

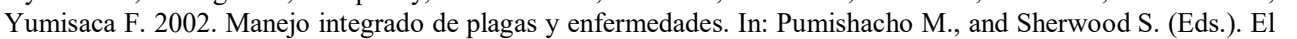

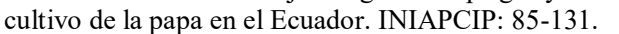

$\square$

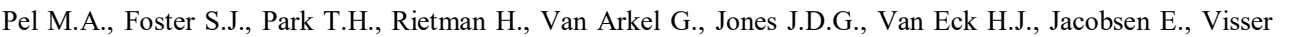

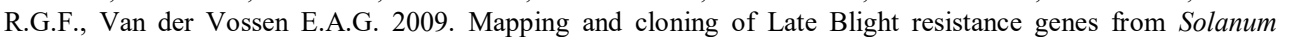

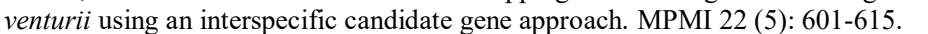

$\square$

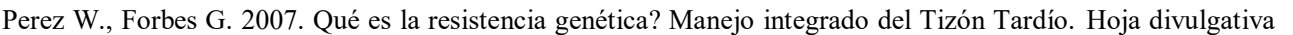

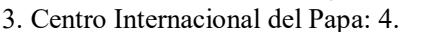

$\square$

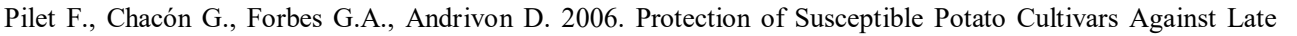

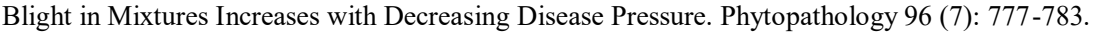
$\square$

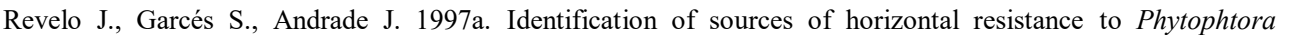

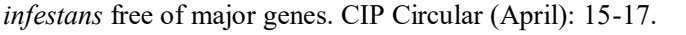

$\square$

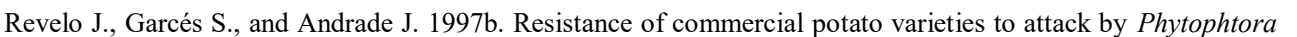

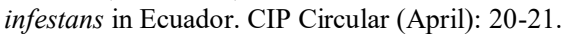

$\square$

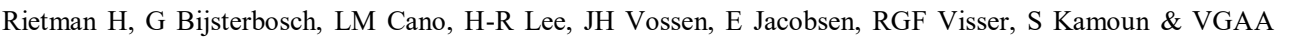

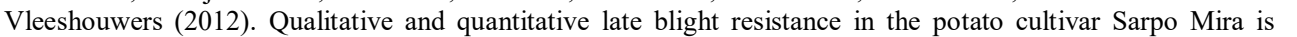

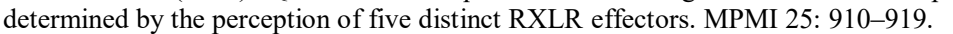

$\square$

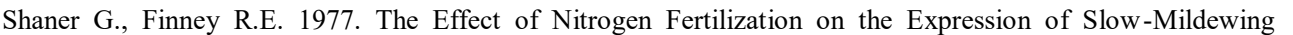

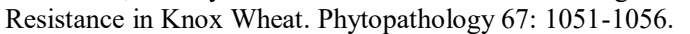

$\square$

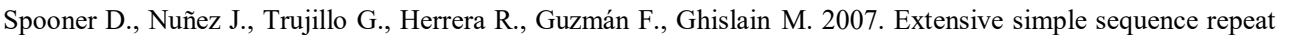
पण

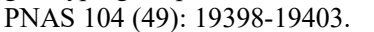

$\square$

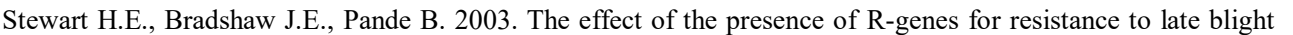

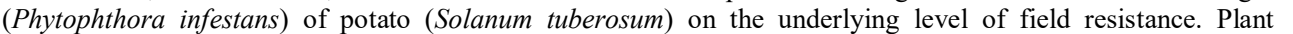

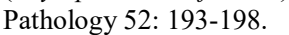

$\square$

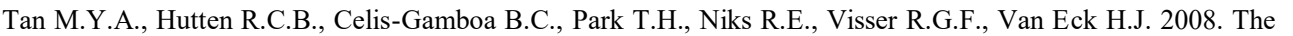

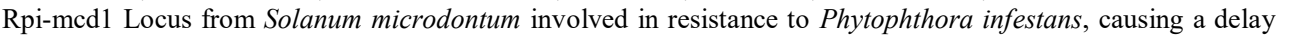
ए पाणामाण

$\square$

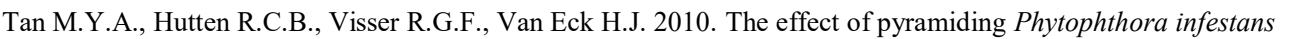

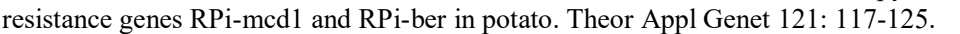
$\square$

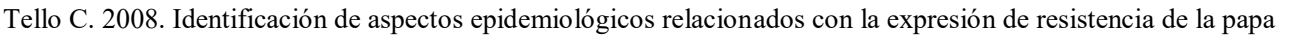

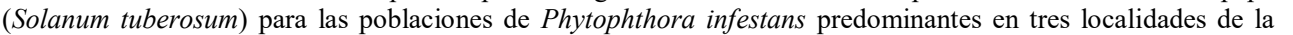

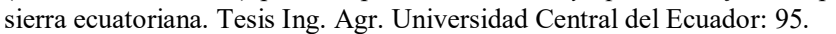

$\square$

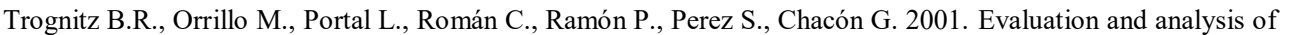
एणी $\square$

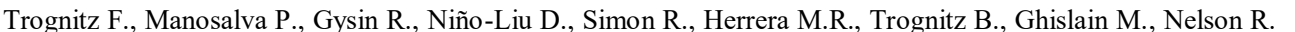

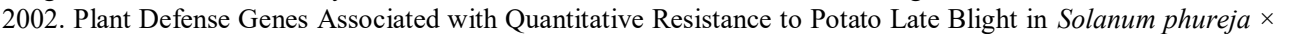

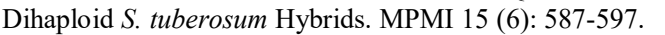
$\square$

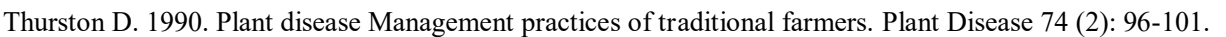
$\square$

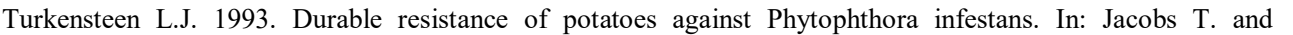

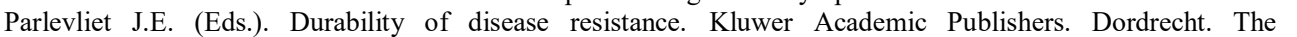

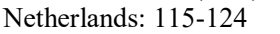

$\square$ 


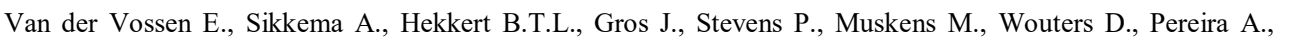

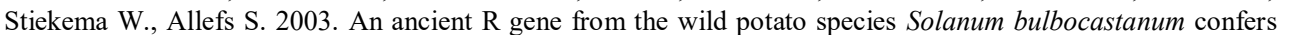

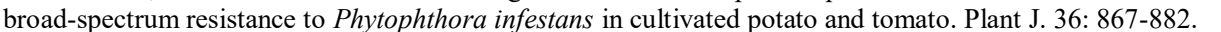
$\square$

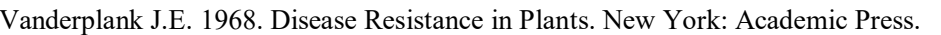
$\square$

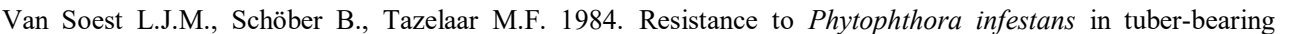

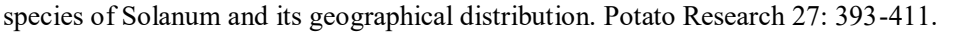
$\square$

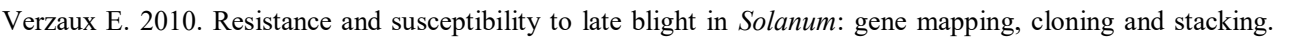

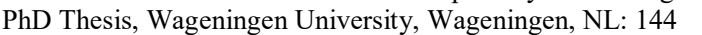

$\square$

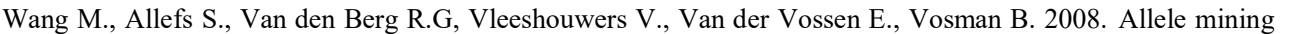

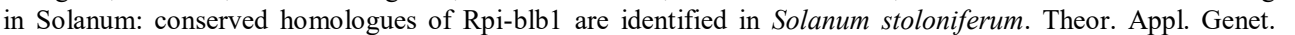
$\square \Pi\|+\square \Pi\|$

$\square$

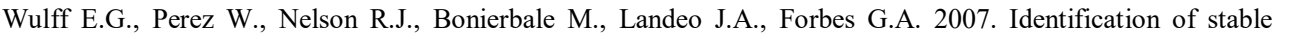

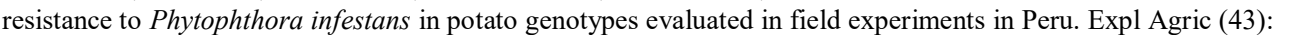
$\square\|\|\|\| \square$ 


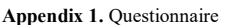

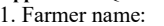

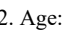

口

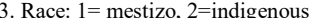

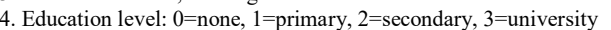

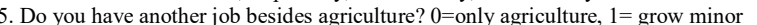

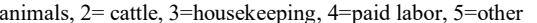

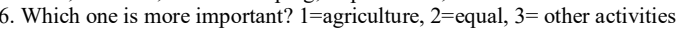

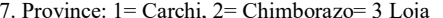

पणमाणा

पणापणताप

पापणाणापा

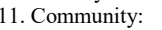

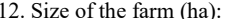

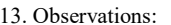

पाणपाणा

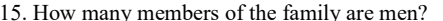

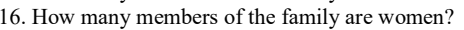

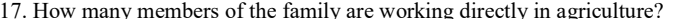

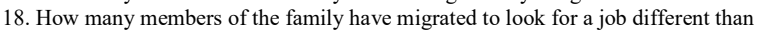

पाणापणाएण

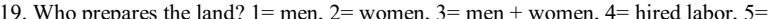

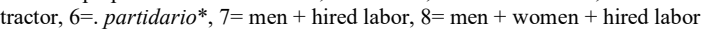

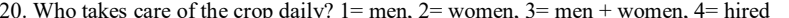

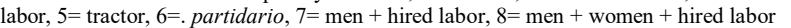

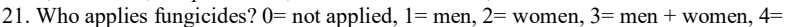

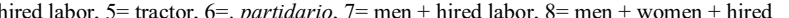

पा1ए

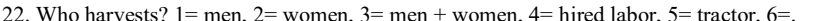

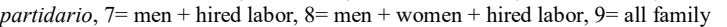

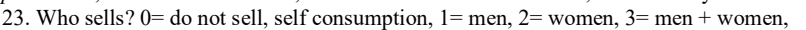

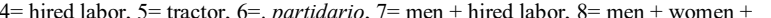

पणाणाणए

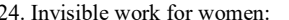

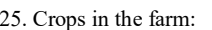

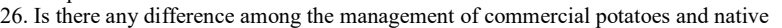

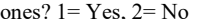

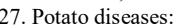

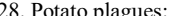

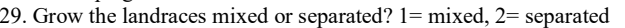

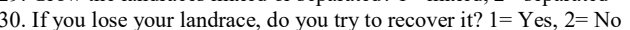

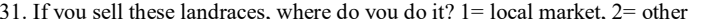

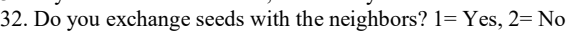

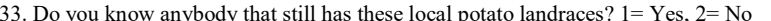

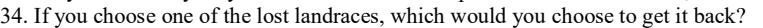

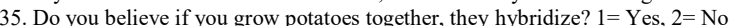

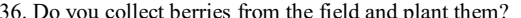

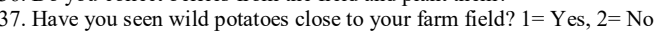

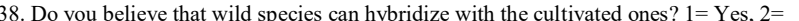

$\square \square$

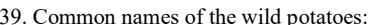

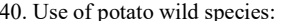

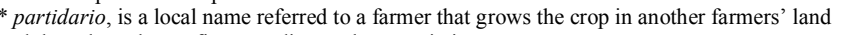

प

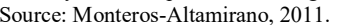




\section{Chapter 6}

\section{Construction of a linkage map using DArT markers and search for QTLs for late blight resistance in a progeny of a cross between two Ecuadorian potato landraces}

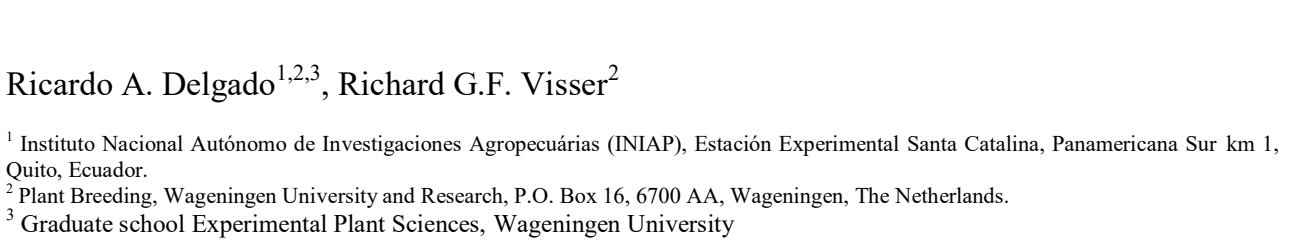

\section{Abstract}

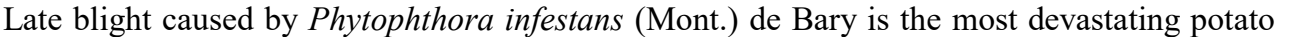

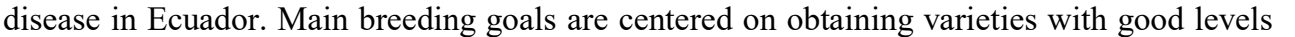

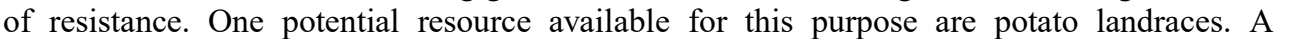

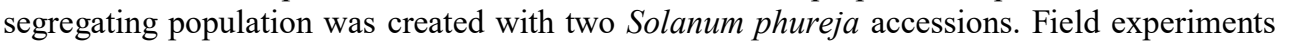

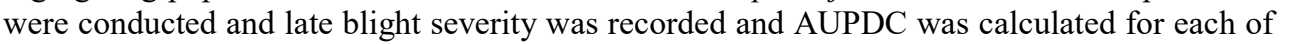

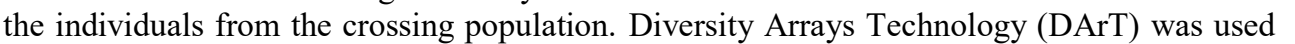

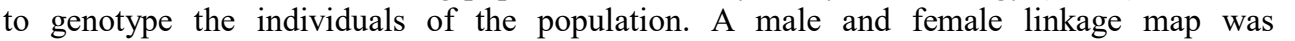

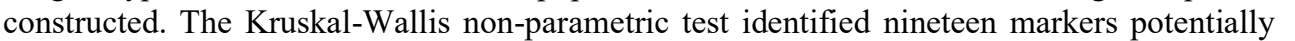

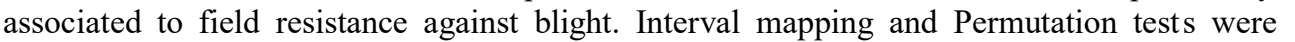

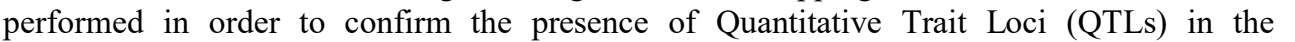

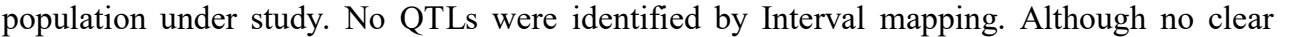

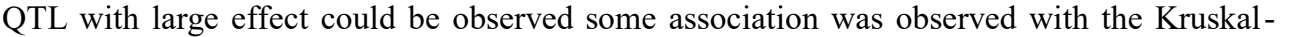

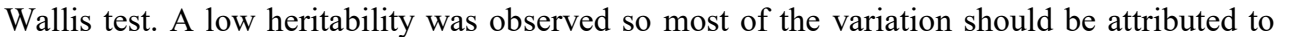

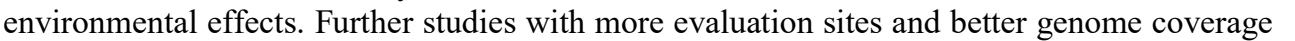

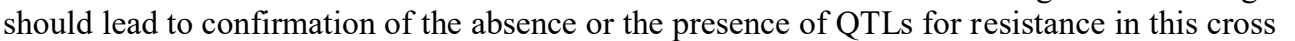

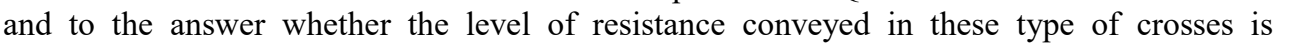

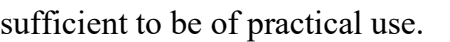

\section{Introduction}

$\square$

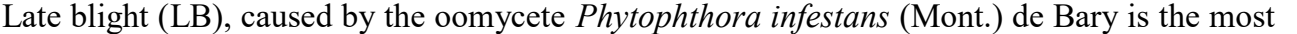

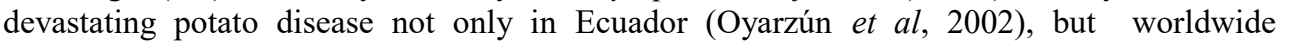

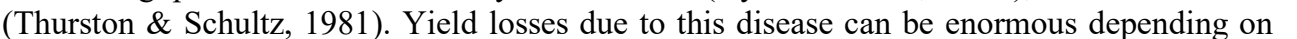

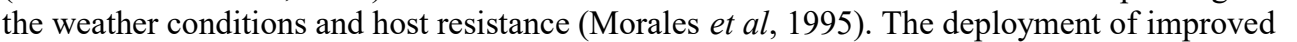

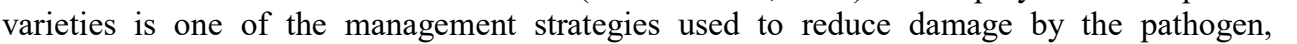

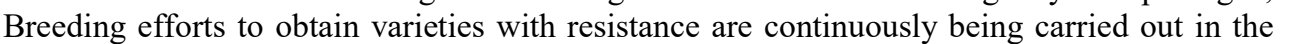

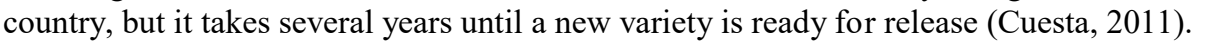




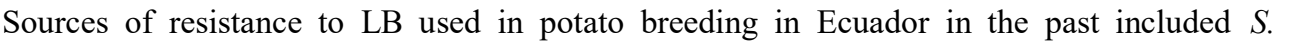

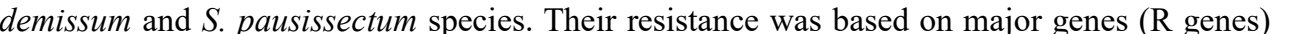
प ए।

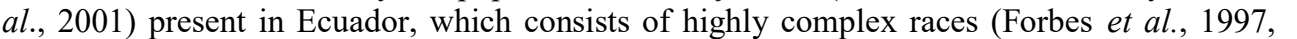

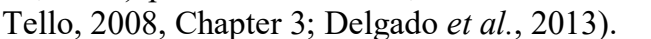

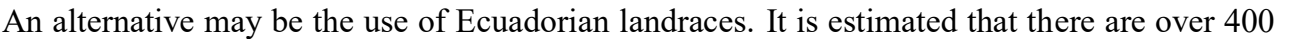

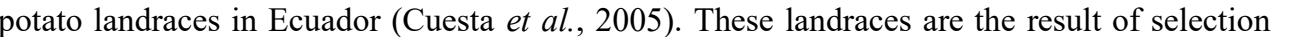

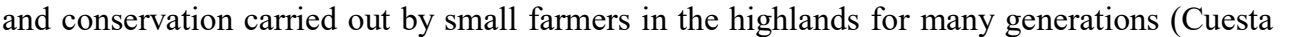

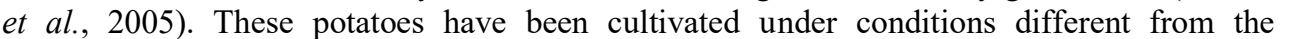

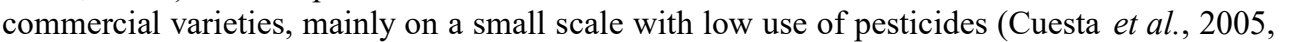

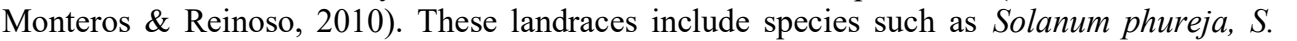

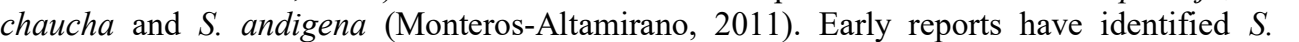

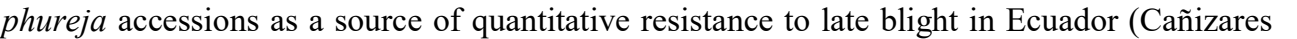

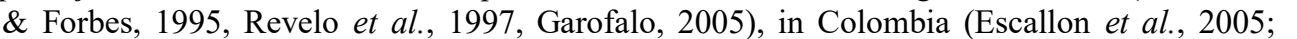

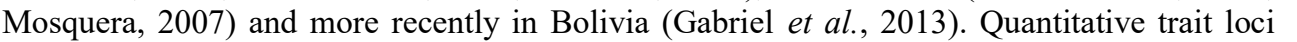

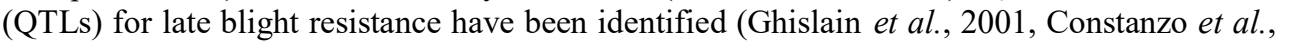

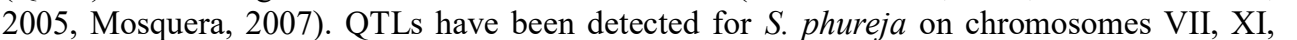

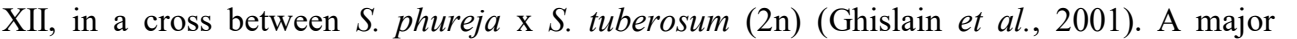

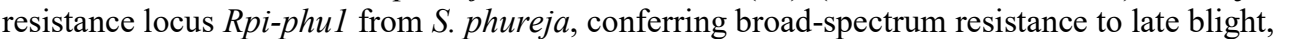

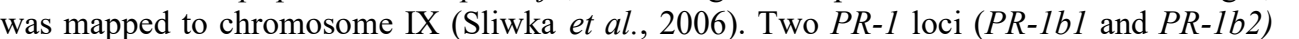

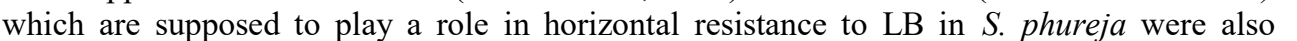

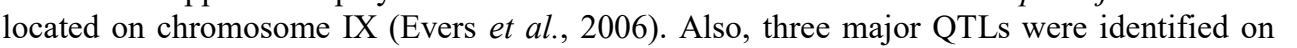

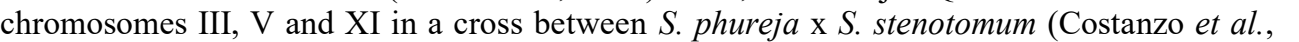

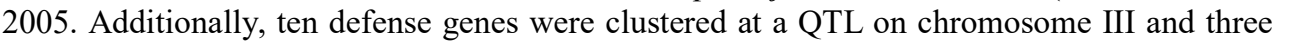

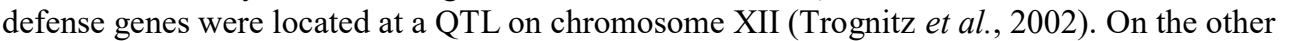

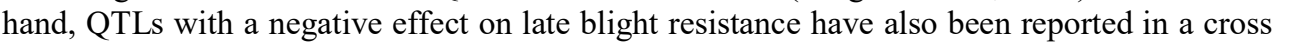

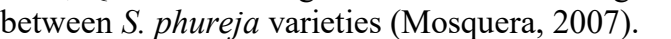

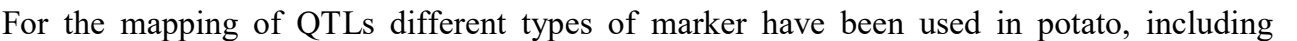

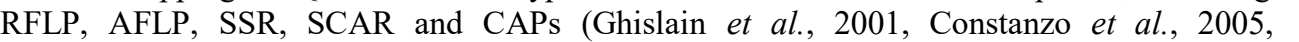

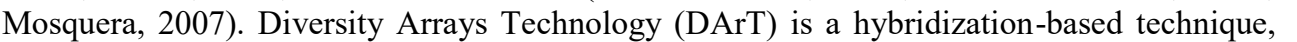

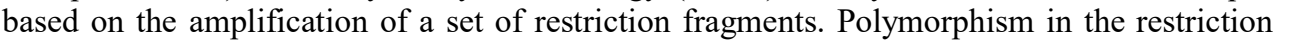

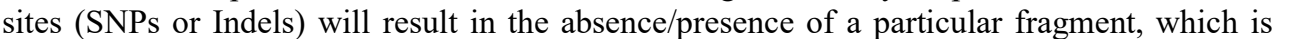

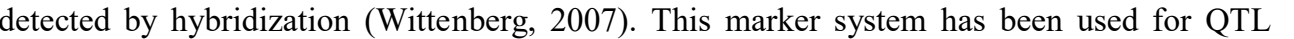

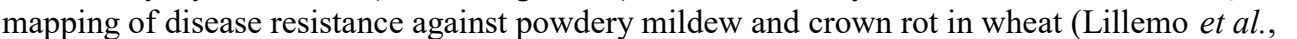

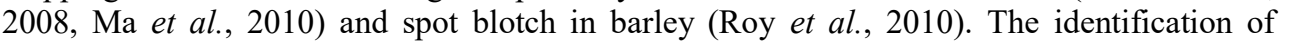

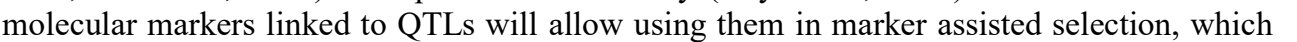

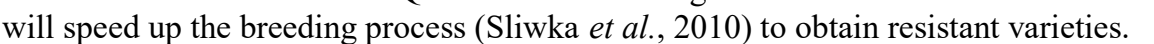

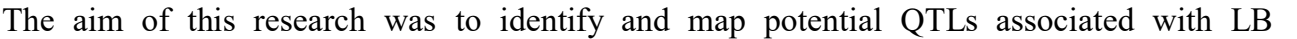

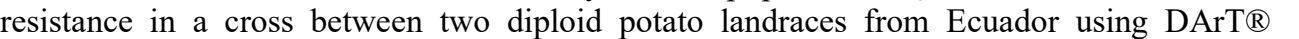

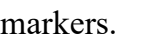

$\square$

\section{Materials and methods}

$\square$

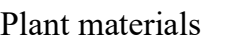

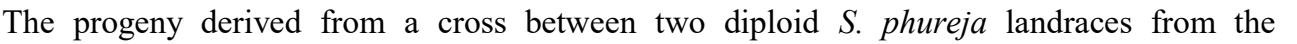

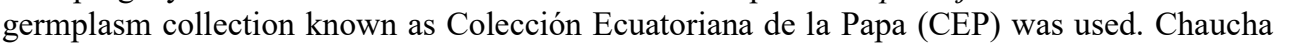




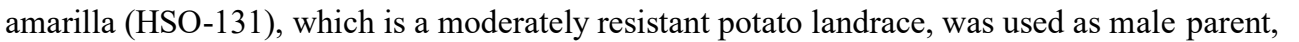

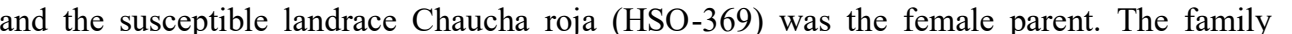

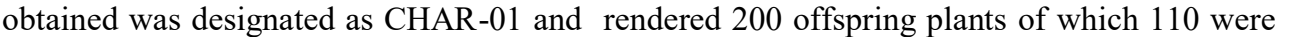

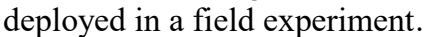

$\square$

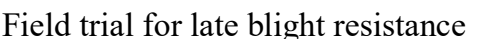

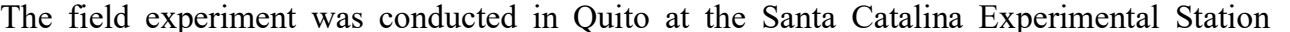

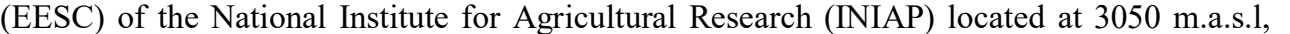
Longitude: $78^{\circ} 33^{\prime} 15^{\prime \prime}$ and Latitude: $00^{\circ} 22^{\prime} 4$ ' S. This location is known to have $\square 1 \| 101 \square \square$

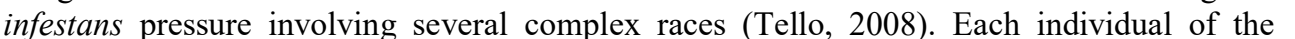

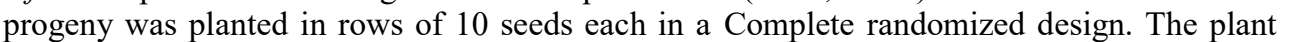

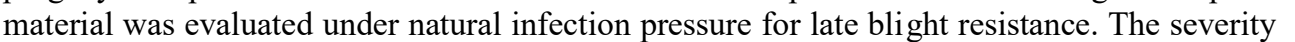

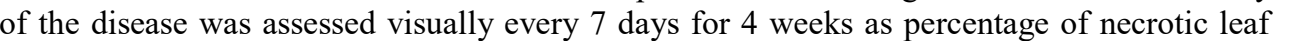

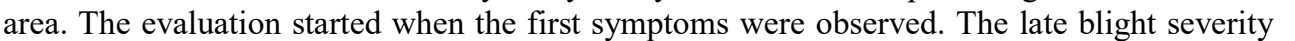

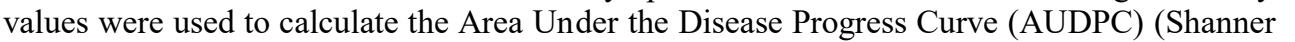

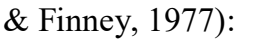

$\square$

$$
\text { AUDPC }=\sum\left[\left(\mathrm{Y}_{\square}\right.\right.
$$

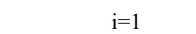

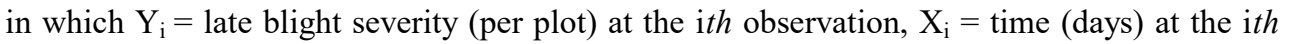

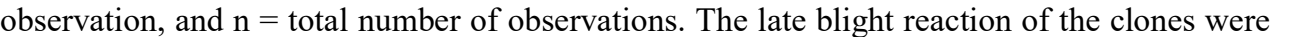
पण

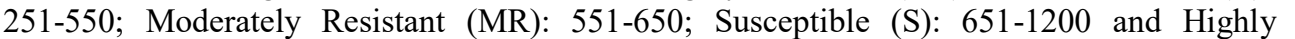

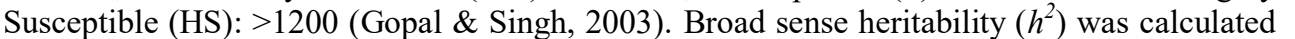

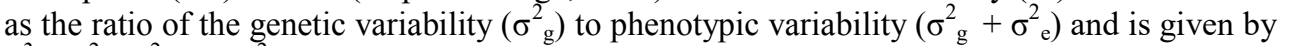

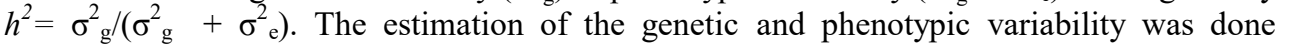

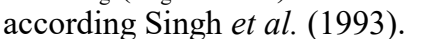

$\square$

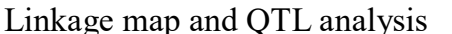

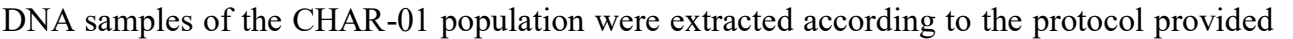

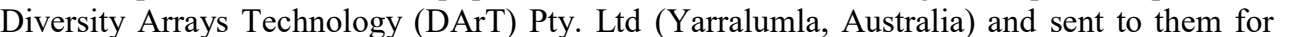

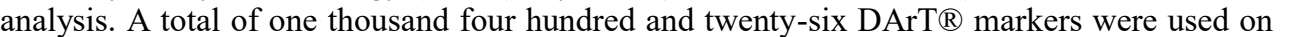

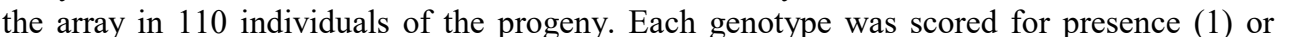

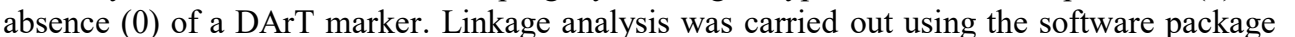

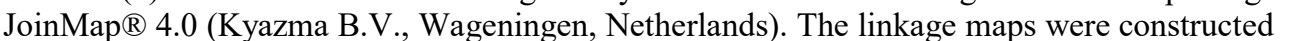
with the Cross Pollinated population type option and Haldane's mapping function linkage

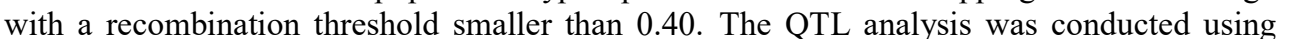

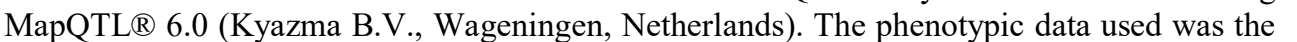

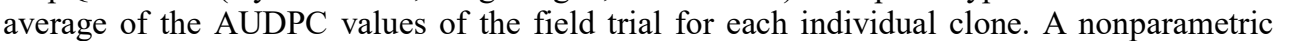

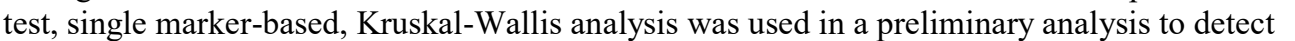

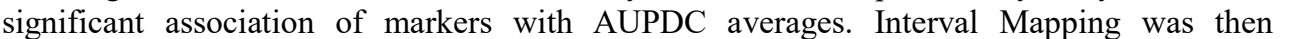

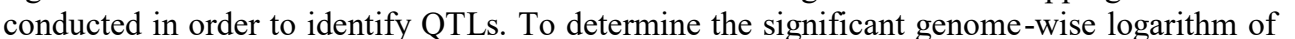

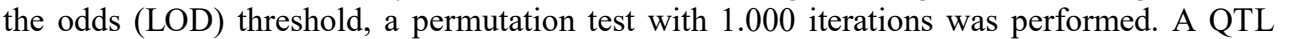

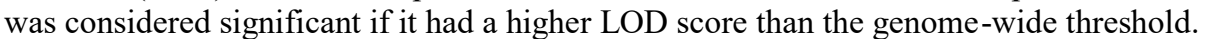




\section{Results}

$\square$

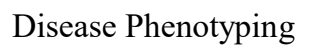

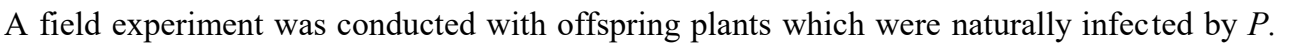

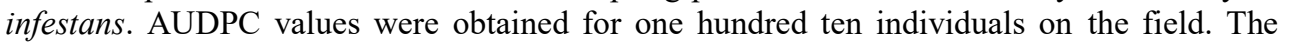

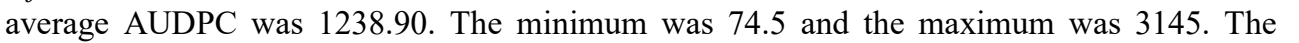

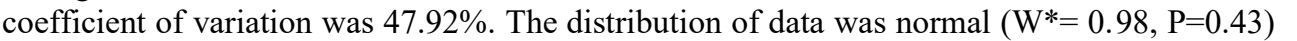

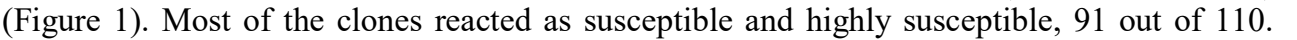

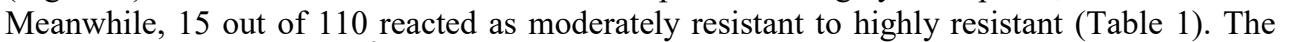

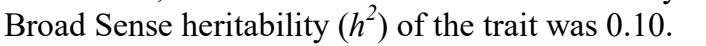

$\square$

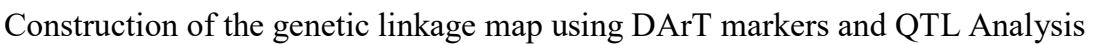

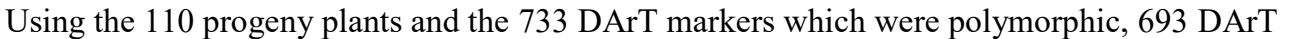

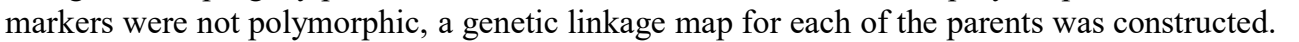

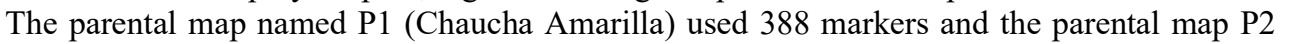

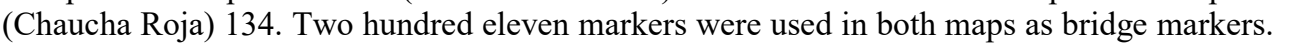

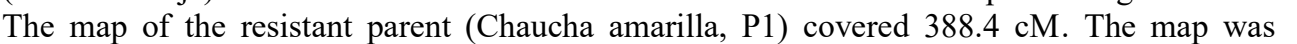

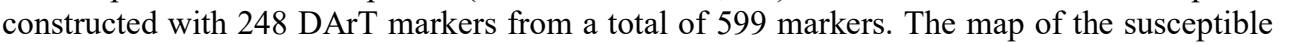

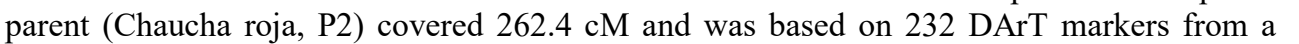

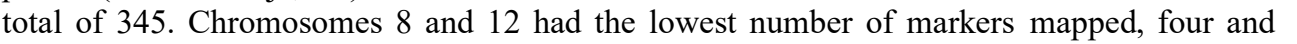

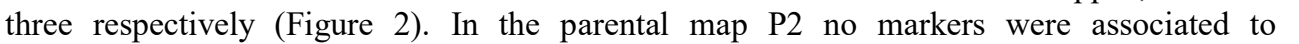

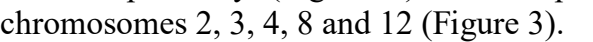

$\square$

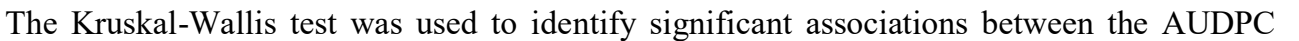

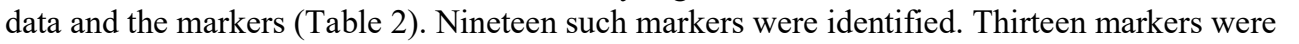

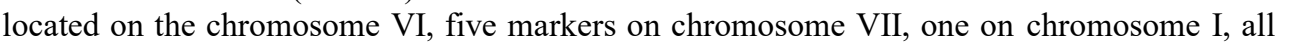

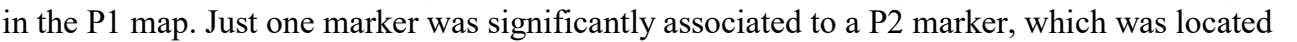

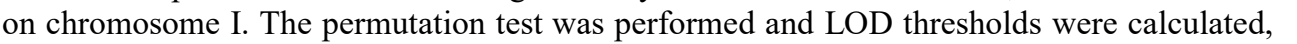

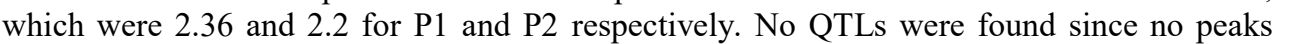

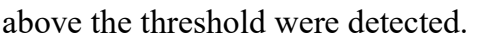

$\square$

\section{Discussion}

$\square$

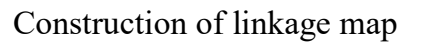

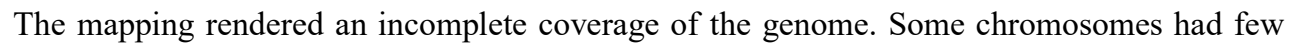

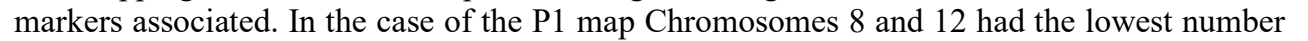

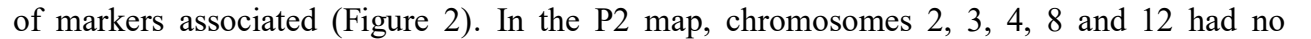

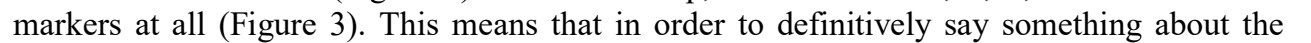

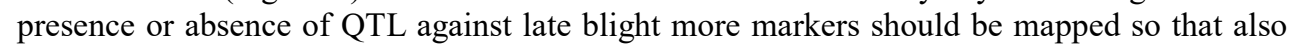

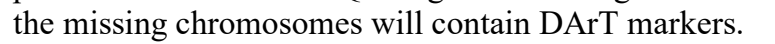

$\square$

$\square$ 


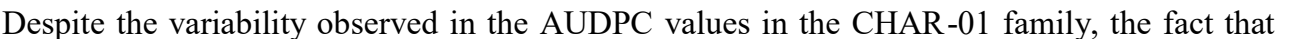
प

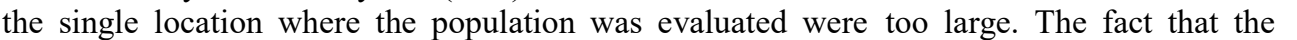

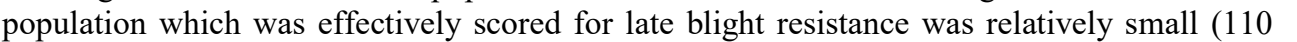

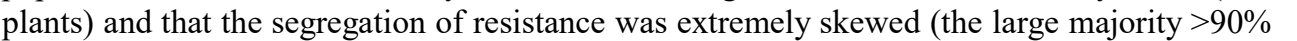

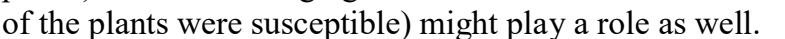

$\square$

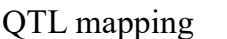

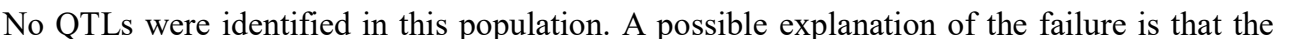

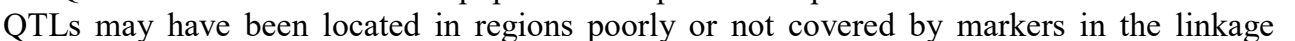

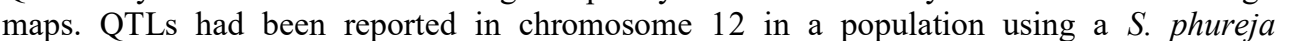

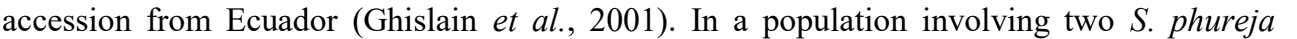

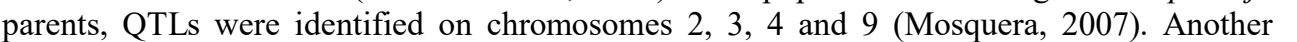

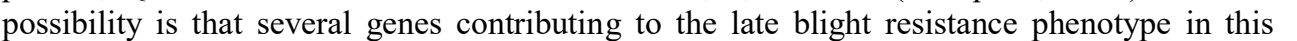

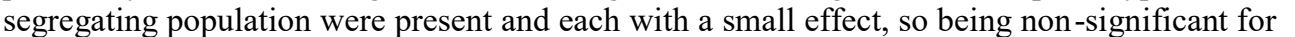

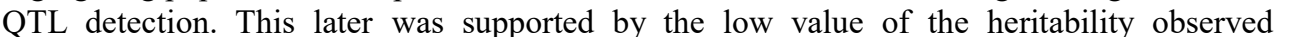

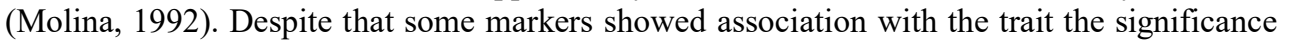
ए ए।

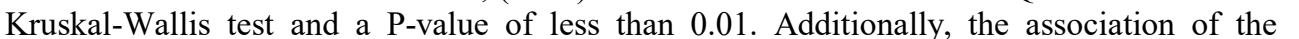

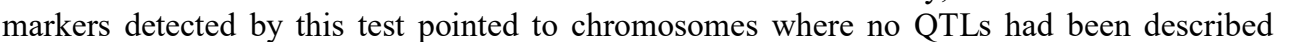

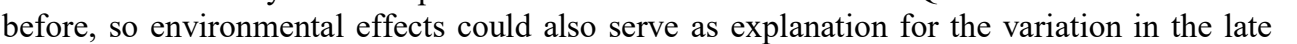

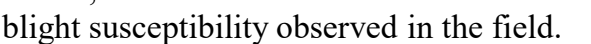

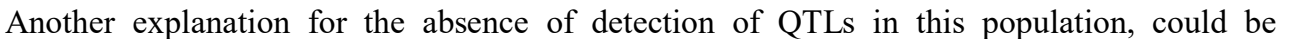

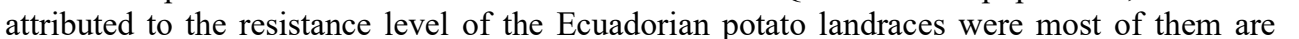

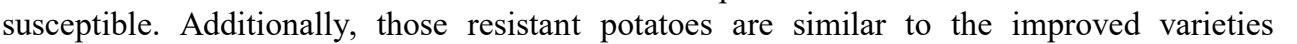

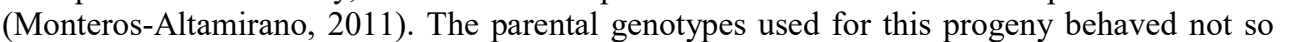

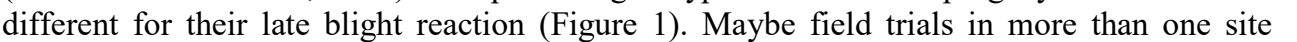

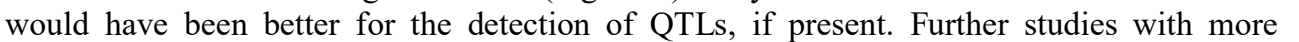

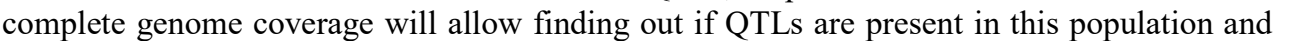

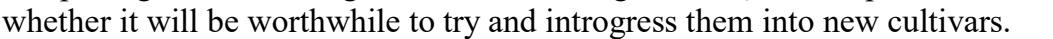

\section{Acknowledgments}

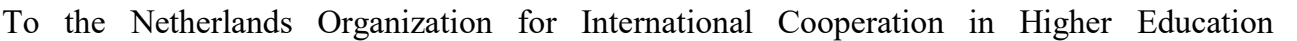

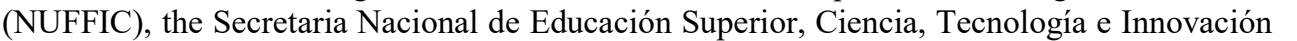

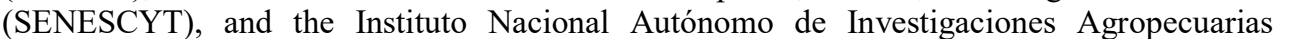

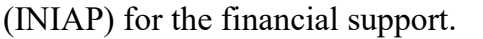

\section{$\square$}

\section{Literature cited}

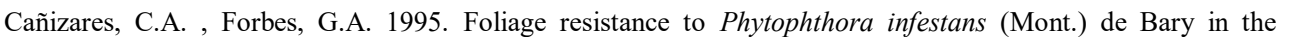

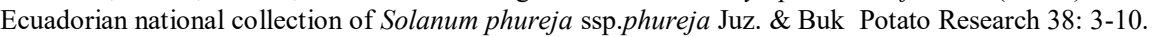




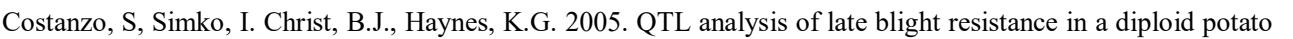

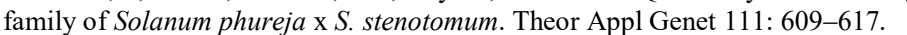

$\square$

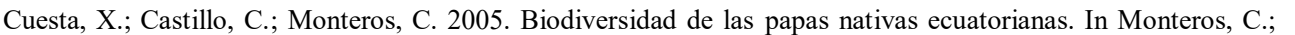

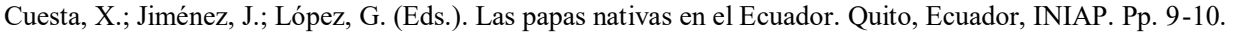
$\square$

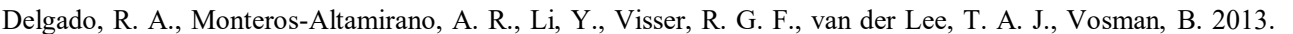

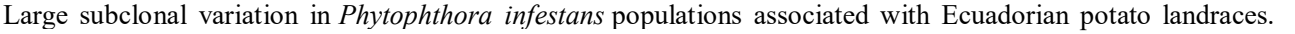

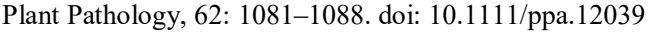

$\square$

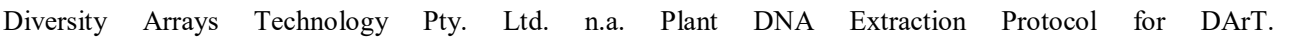

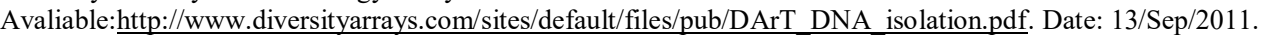
$\square$

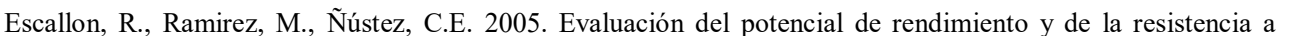

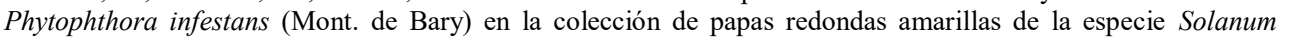

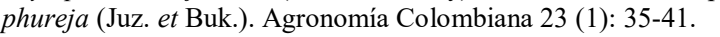

$\square$

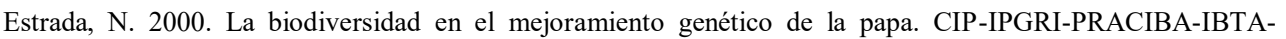
ㅁำ

$\square$

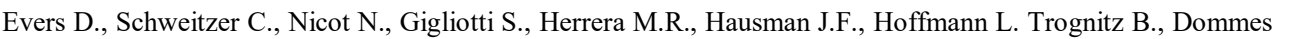

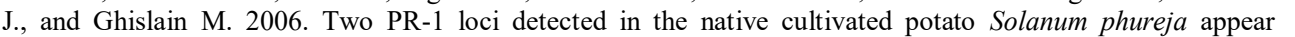

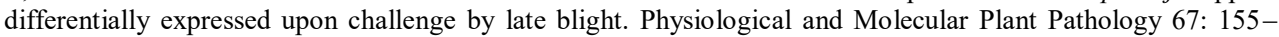
पाIII)

$\square$

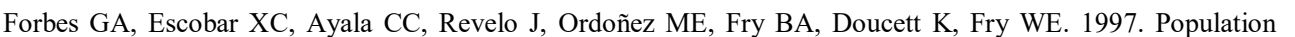

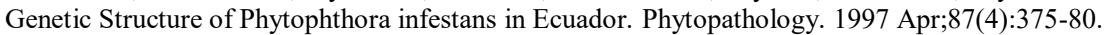
$\square$

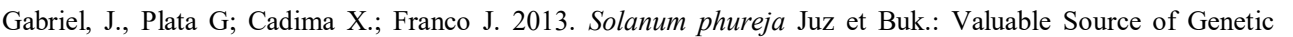

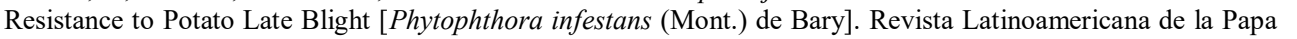

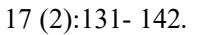

$\square$

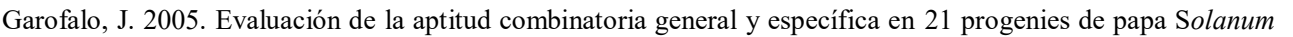

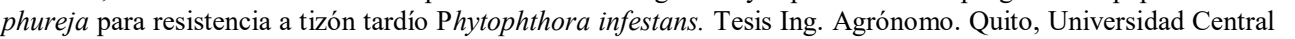

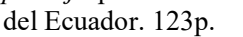

$\square$

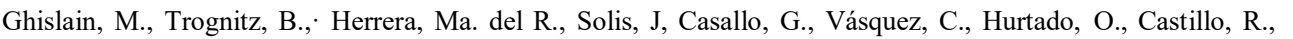

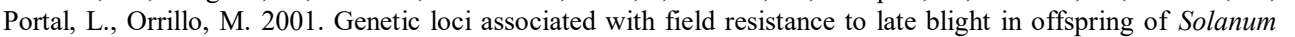

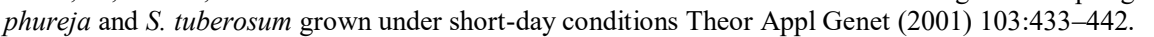
$\square$

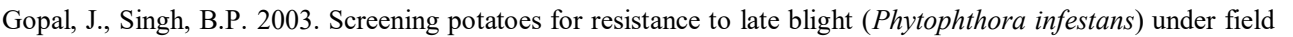

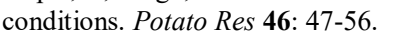

$\square$

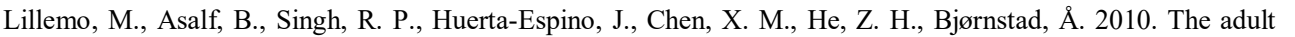

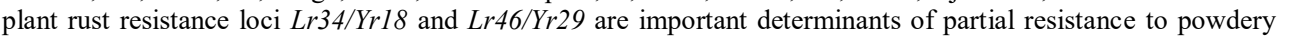

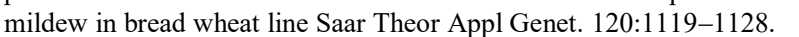
$\square$

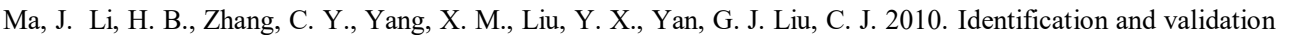

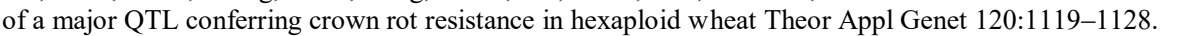
$\square$

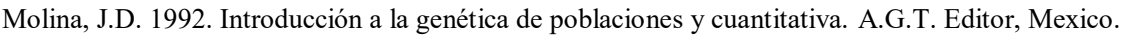
$\square$

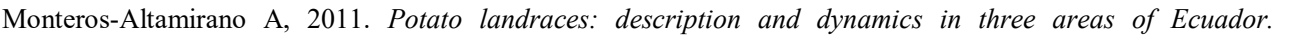

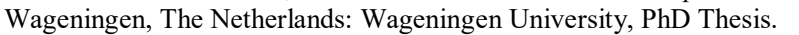
$\square$

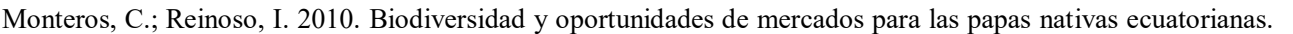

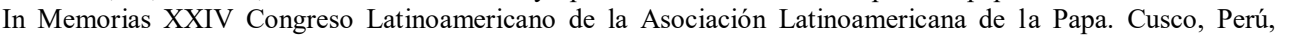

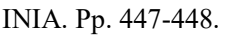

$\square$ 


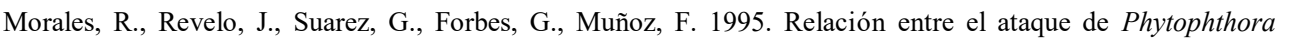

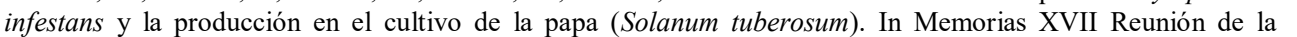

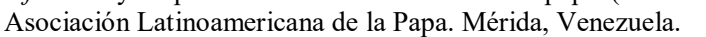

$\square$

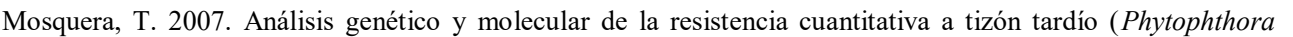

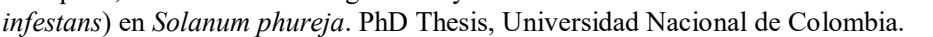

$\square$

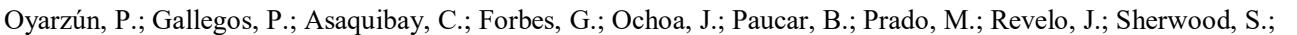

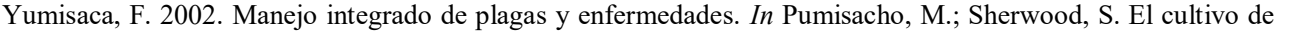

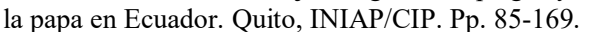

$\square$

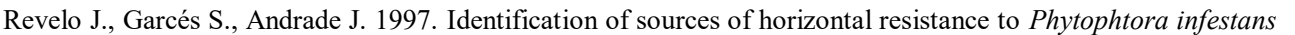

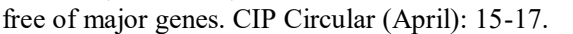

$\square$

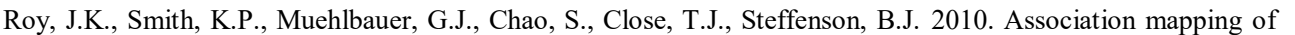

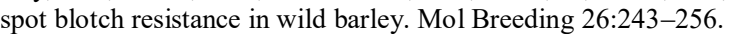

$\square$

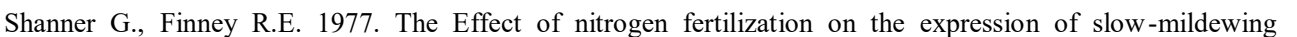

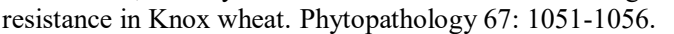

$\square$

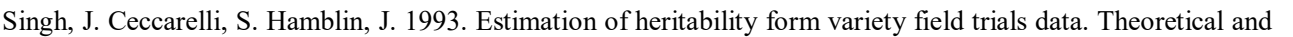

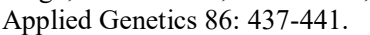

$\square$

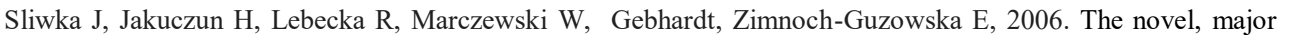

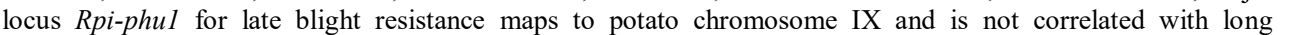

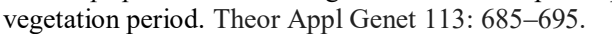

$\square$

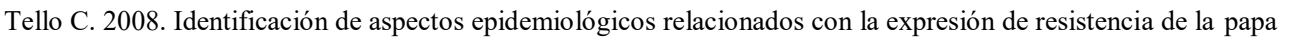

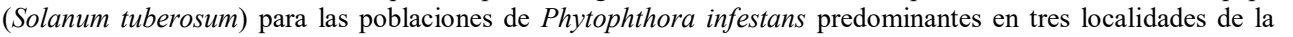

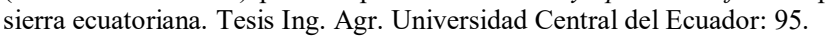

$\square$

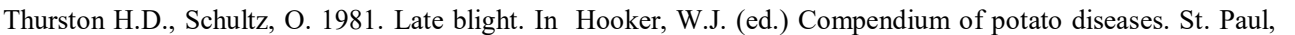

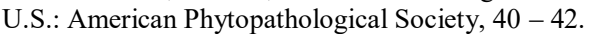

$\square$

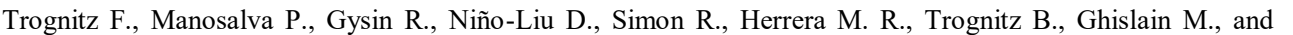

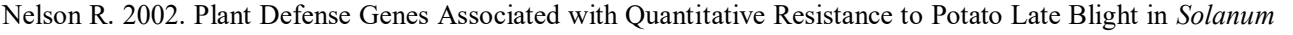

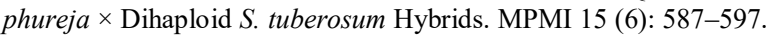
$\square$

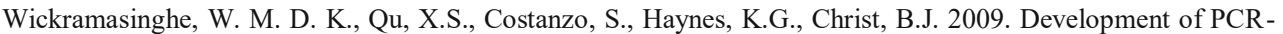

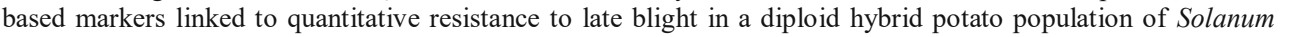

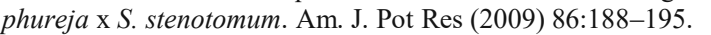

$\square$

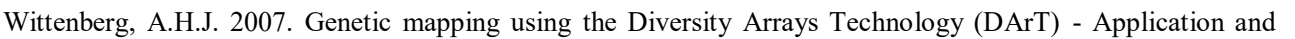

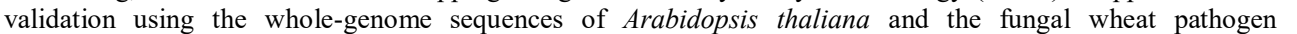

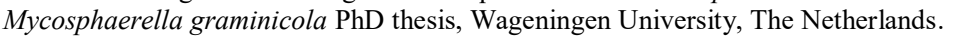




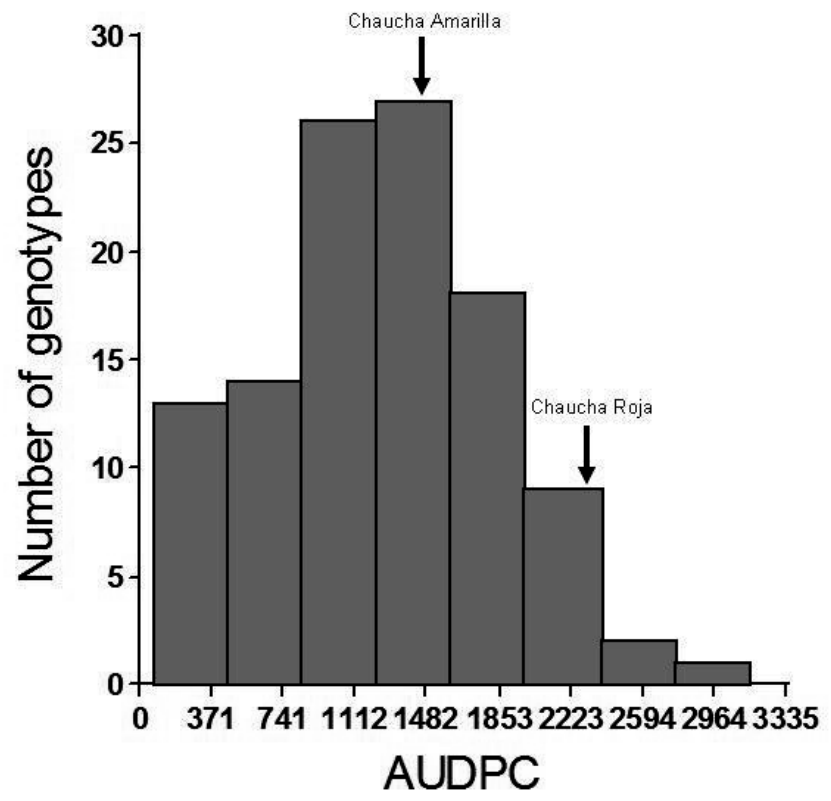

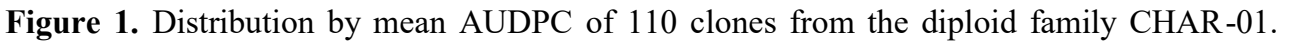

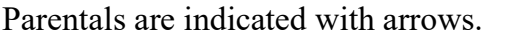

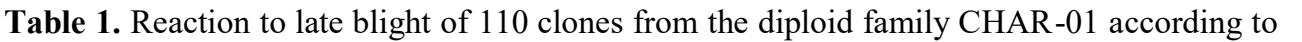

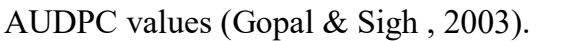

\begin{tabular}{|c|c|c|}
\hline 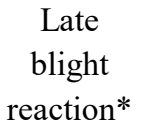 & $\square \square 1 \| \sqcap \square$ & 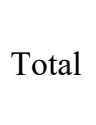 \\
\hline$\square \square \square$ & 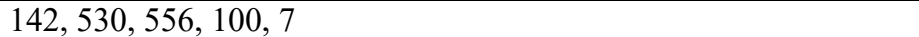 & $\square$ \\
\hline$\square \square$ & 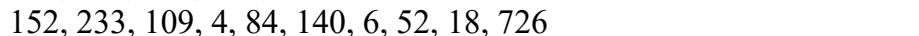 & $\square \square$ \\
\hline$\square \square \square$ & $\square|\|||||||||| \mid$ & $\square$ \\
\hline$\square \square$ & 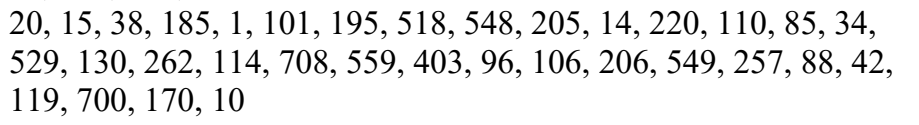 & $\square \square$ \\
\hline$\square \square \square$ & 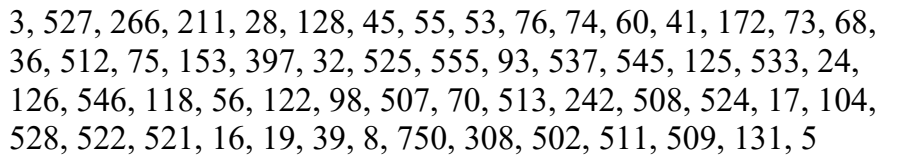 & $\square \square$ \\
\hline
\end{tabular}

प

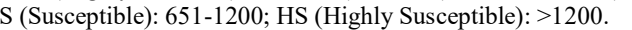



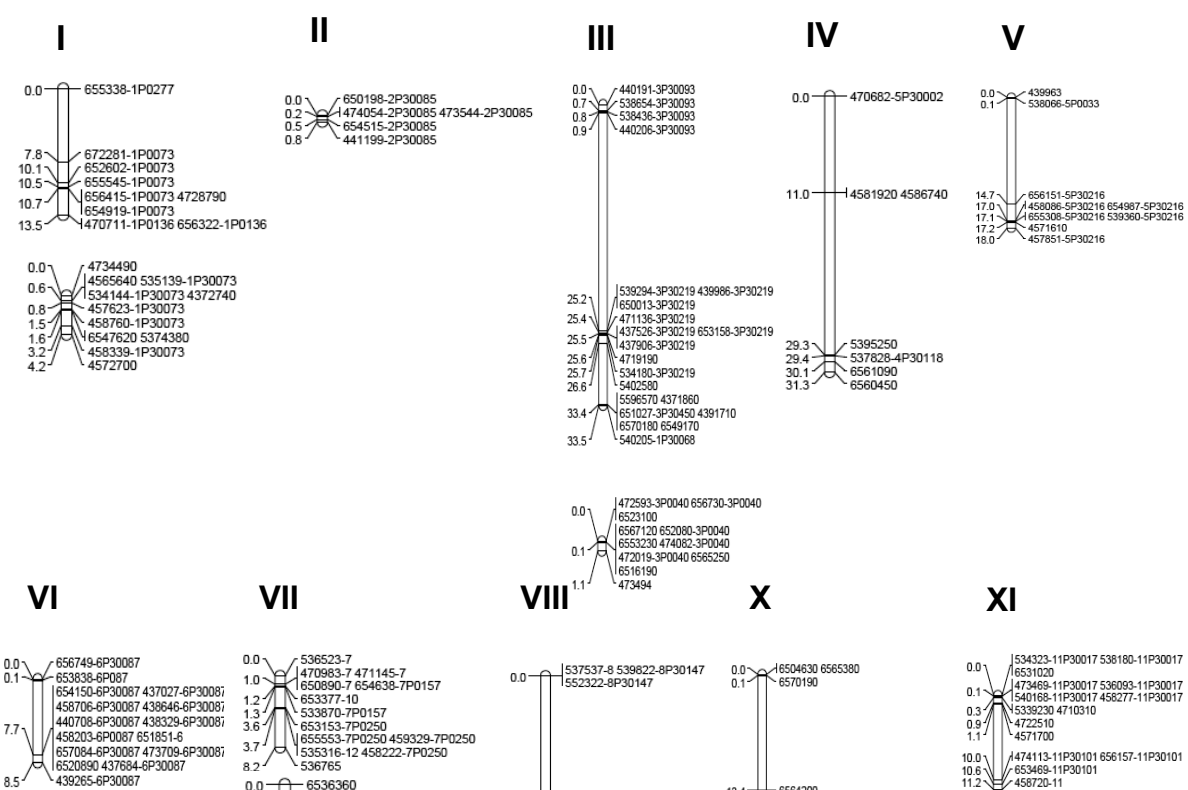

\section{VII}

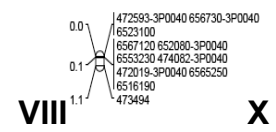

\section{$\mathbf{X I}$}
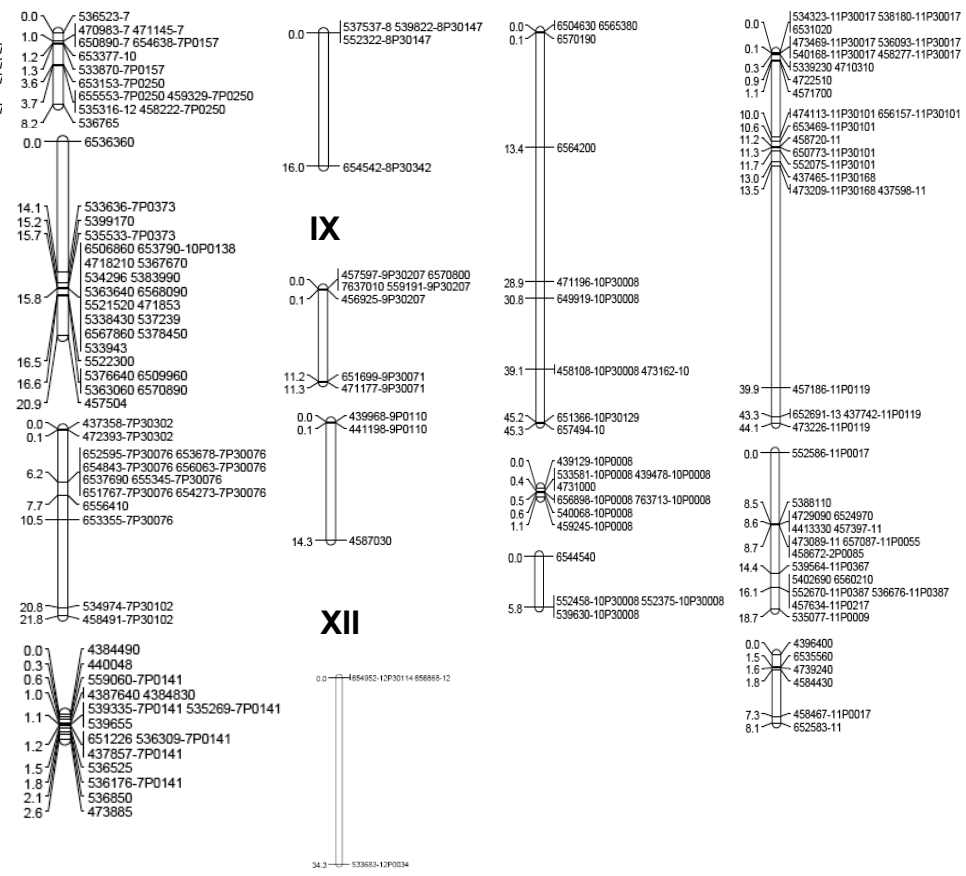

Figure 2. 
$\square$ I
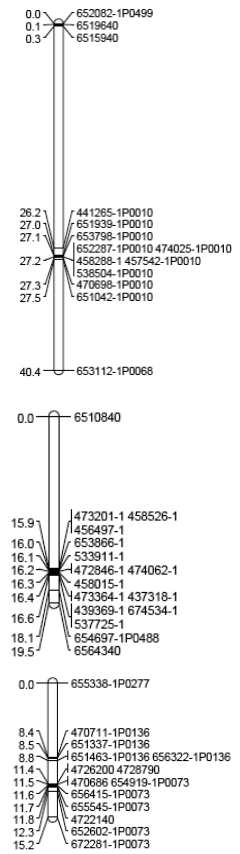

$\mathbf{x}$

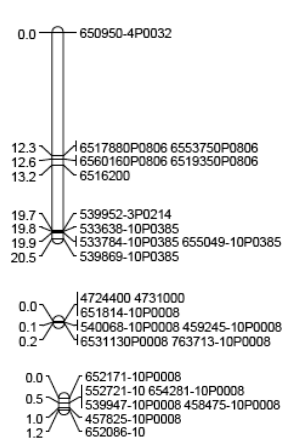

V
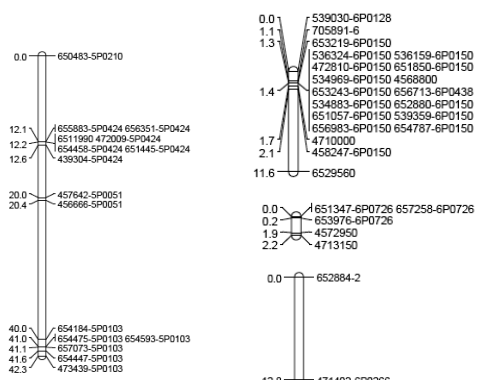

${ }_{11.6}^{2.1} \mathcal{C}_{6529560}$

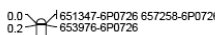

$\begin{aligned} & 0.2 \\ & 1.9\end{aligned}-455976-6$
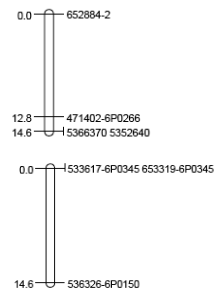

VII
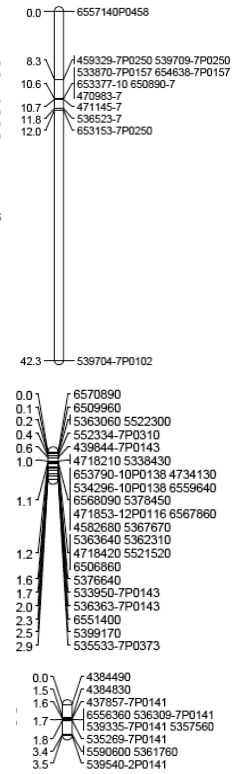

IX

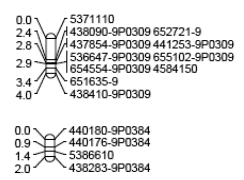

\section{$\mathbf{X I}$}
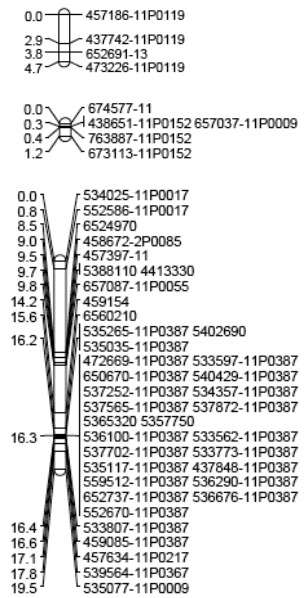

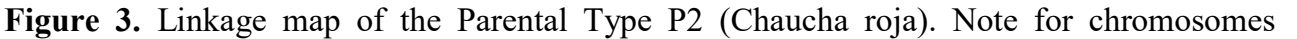

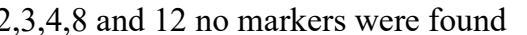




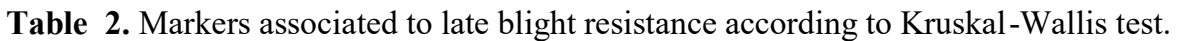

\begin{tabular}{|c|c|c|c|c|}
\hline 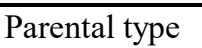 & $\overline{\square \square\|\square \square\| \square \square}$ & $\square \square \square \square \square$ & $\overline{\square \square}$ & $\overline{\square \square}$ \\
\hline 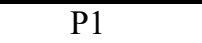 & $\square \square$ & 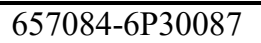 & $\overline{\square \square I}$ & 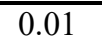 \\
\hline$\square \square$ & $\square \square$ & $\square\|\Pi\|$ & पणा & 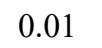 \\
\hline$\square \square$ & $\square \square$ & $\square\|\|\|\| \square \square\|\| \square$ & $\square \amalg$ & 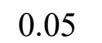 \\
\hline$\square \square$ & $\square \square$ & $\square\|\|\|\| \square \square \| \square$ & $\square \amalg$ & $\square \square \square$ \\
\hline$\square \square$ & $\square \square$ & 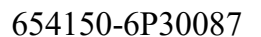 & $\square \amalg$ & $\square \square$ \\
\hline$\square \square$ & $\square \square$ & $\square\|\|\|\| \square\|\| \|$ & $\square \amalg$ & $\square \square \square$ \\
\hline$\square \square$ & $\square \square$ & $\square\|\|\|\| \square \square \| \square$ & $\square \amalg$ & $\square \square \square$ \\
\hline$\square \square$ & $\square \square$ & $\square\|\|\|\|\|\| \| \square$ & $\square \square$ & $\square \square \square$ \\
\hline$\square \square$ & $\square \square$ & 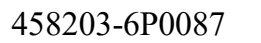 & $\square \square$ & 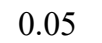 \\
\hline$\square \square$ & $\square \square$ & 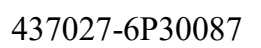 & $\square \square$ & $\square \square$ \\
\hline$\square \square$ & $\square \square$ & $\square\|\|\|\| \square\|\| \|$ & पणI & $\square \square$ \\
\hline$\square \square$ & $\square \square$ & $\square\|1\| \square$ & $\square \square$ & $\square \square \square$ \\
\hline$\square \square$ & $\square \square$ & $\square\|\|\|\| \square\|\| \|$ & $\square \amalg$ & $\square \| \square$ \\
\hline$\square \square$ & $\square \square$ & $\square\|\| \| \square$ & $\square \amalg$ & $\square \square \square$ \\
\hline$\square \square$ & $\square \square$ & $\square\|\|\|\| \square\|\| \|$ & $\square \square$ & $\square \square$ \\
\hline$\square \square$ & 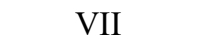 & $\square\|\| \square$ & $\square \amalg$ & $\square \square \square$ \\
\hline$\square \square$ & $\square \square$ & $\square\|\Pi\|$ & $\square \amalg$ & $\square \square$ \\
\hline$\square \square$ & प्राण & $\square\|\|\|\| \square\|\| \|$ & $\square \amalg$ & $\square \square \square$ \\
\hline$\square \square$ & $\square$ & $\square\|\|\|\| \square \square \| \square$ & $\square \square$ & $\square \square \square$ \\
\hline$\square \square$ & $\square$ & $\square\|\|\|\| \square\|\| \square$ & 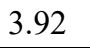 & $\square \square \square$ \\
\hline
\end{tabular}




\title{
Chapter 7
}

\section{Late blight response and yield characteristics of potato varieties in two environments in Chimborazo province, Ecuador}

\begin{abstract}
$\square$

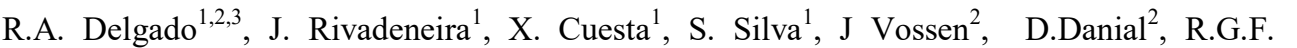

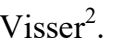

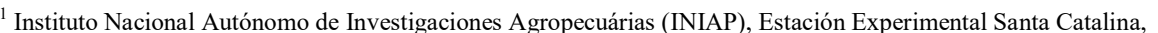

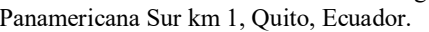

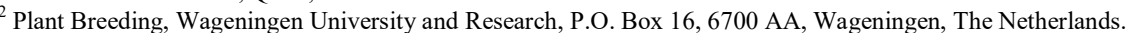

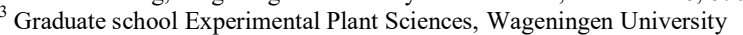

$\square$

\begin{abstract}

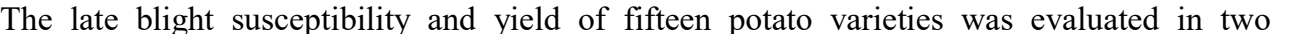
पा

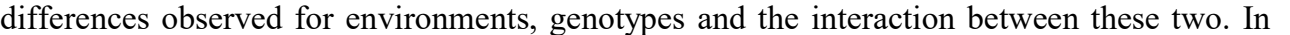

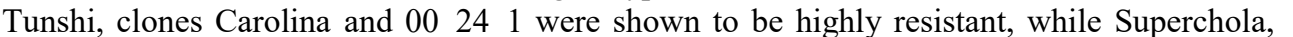

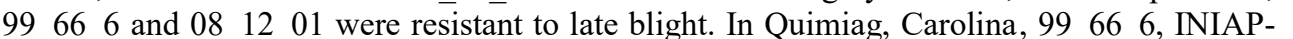

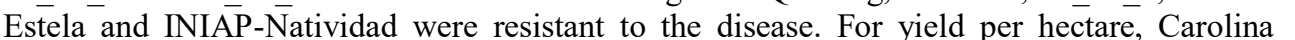

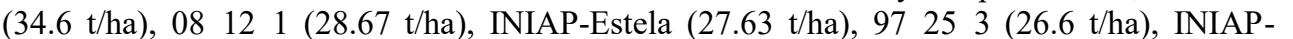

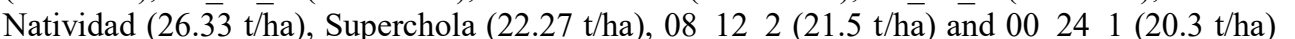

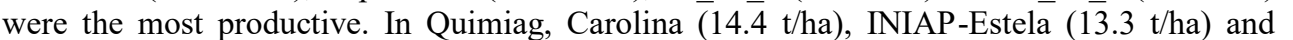

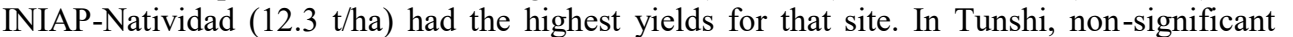

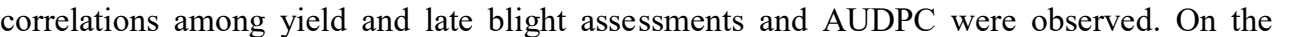

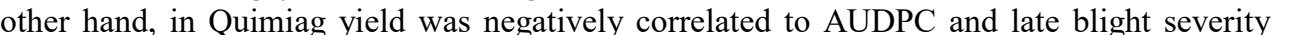

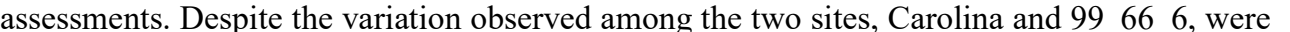

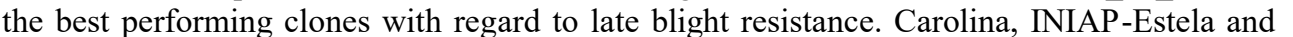

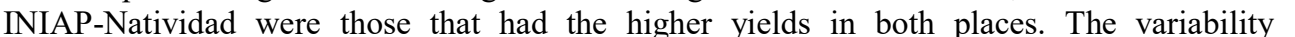

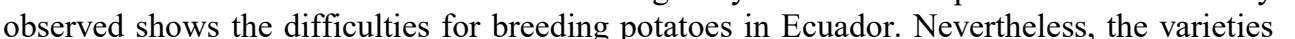

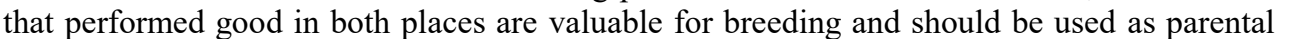

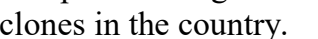

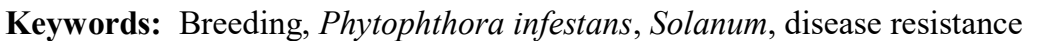




\section{Introduction}

ए

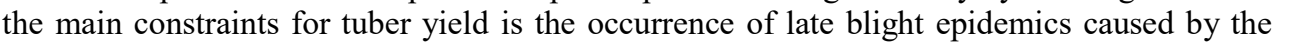

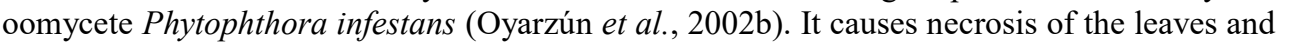

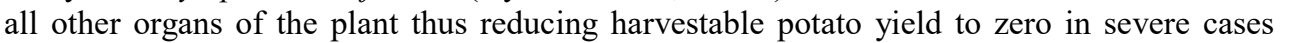

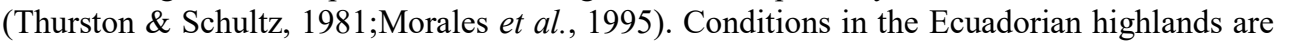

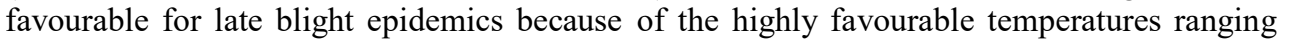

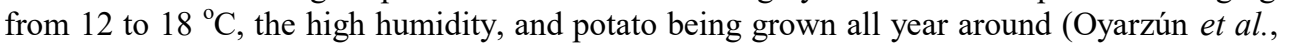
$\square 111 \|$

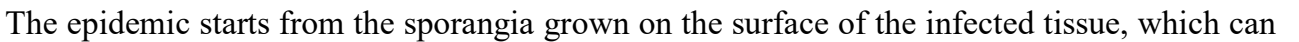

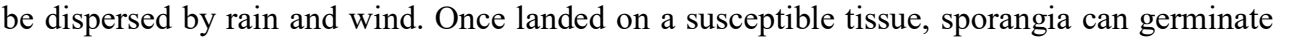

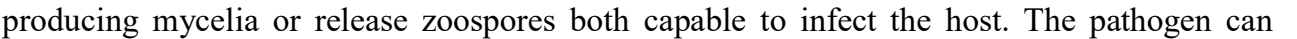

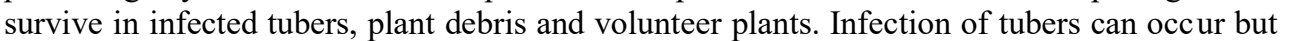

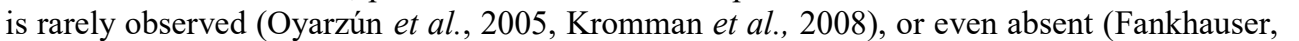

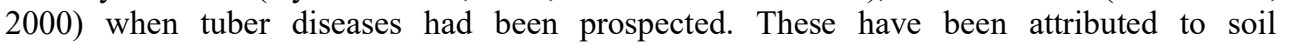

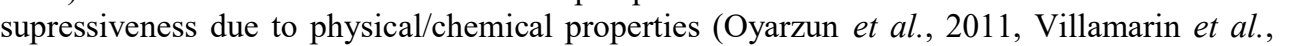

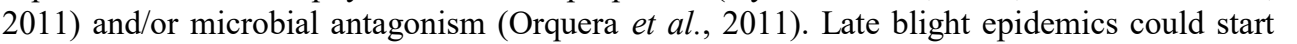

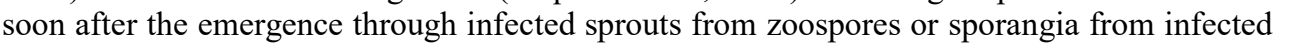

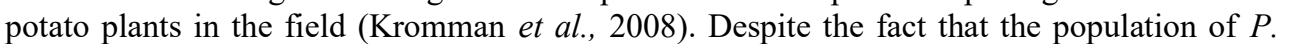

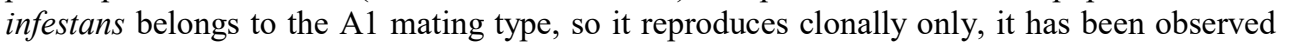

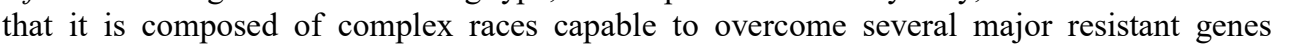
ए

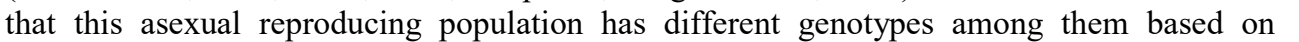

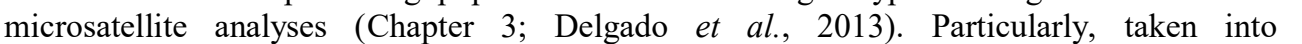

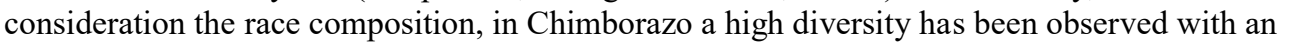

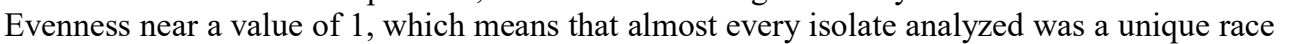

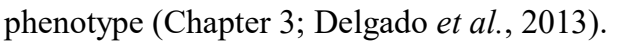

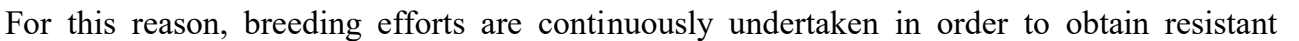

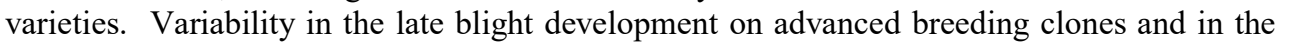

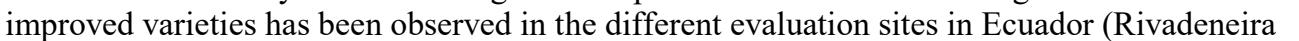

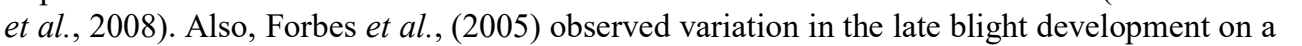

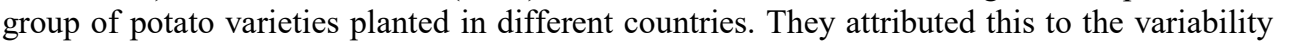

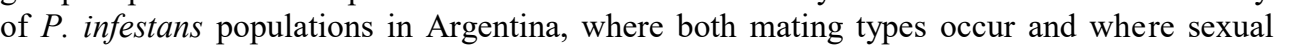

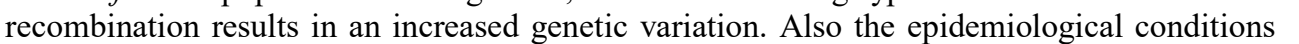
ए

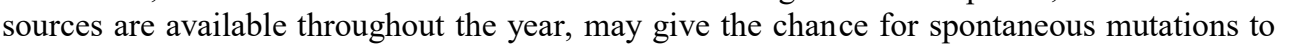

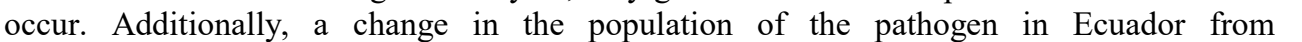

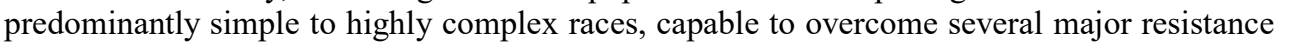

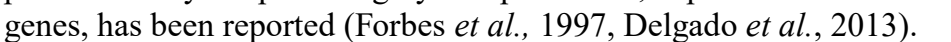

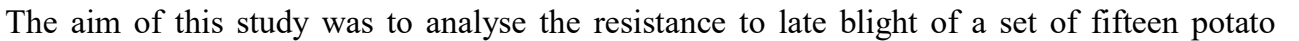

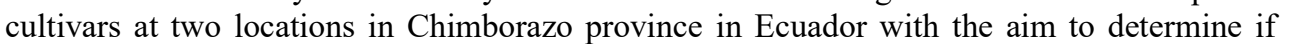
प

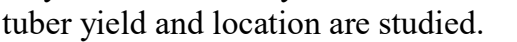




\section{Materials and methods}

$\square$

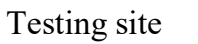

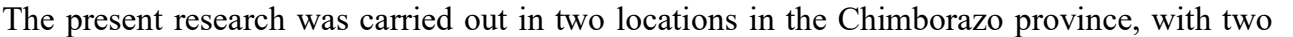

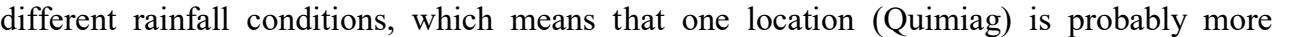

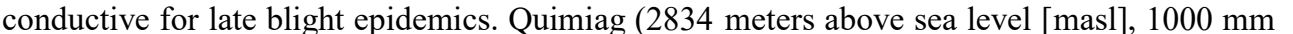

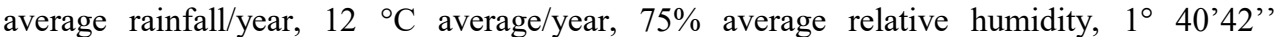

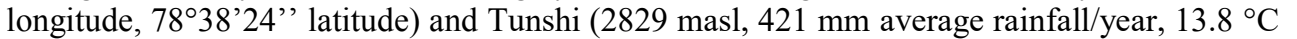

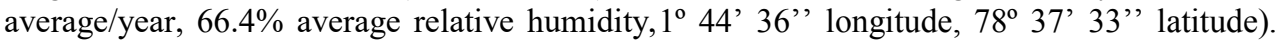

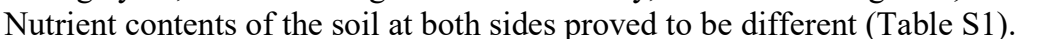

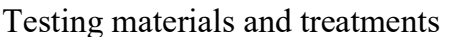

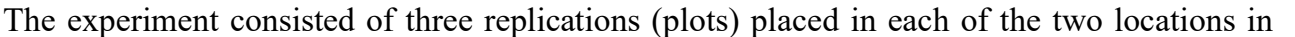

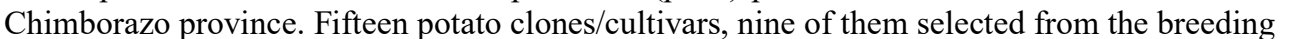

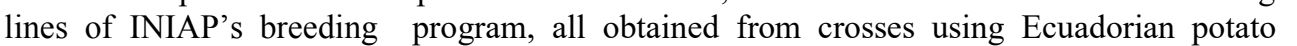

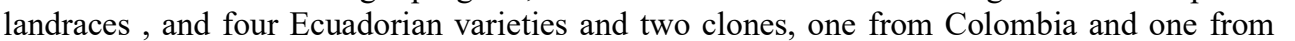

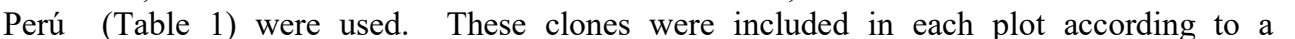

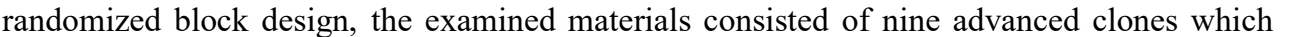

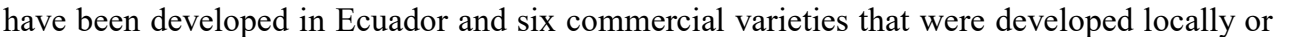

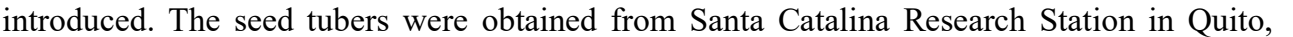

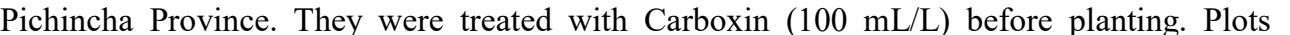

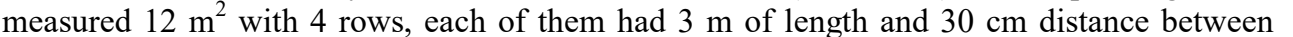

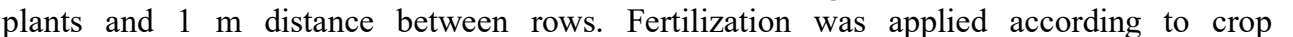

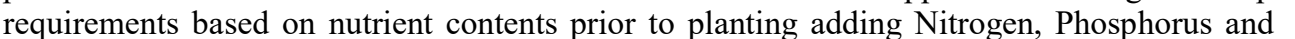

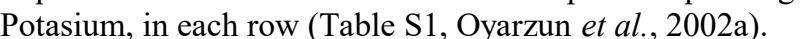

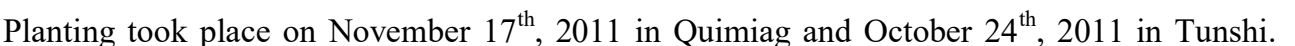

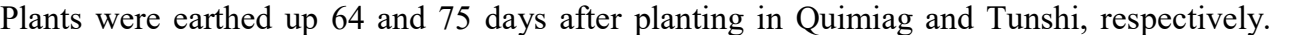

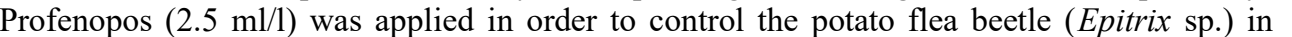

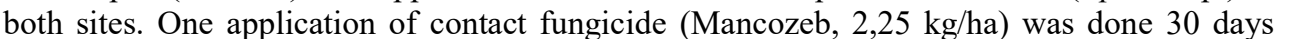

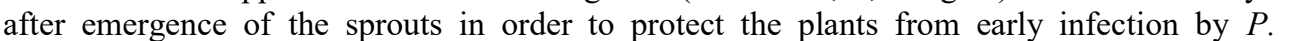

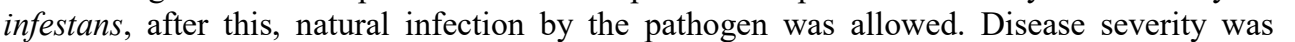

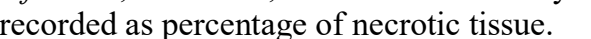

$\square$

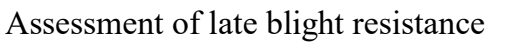

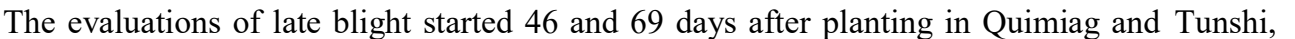

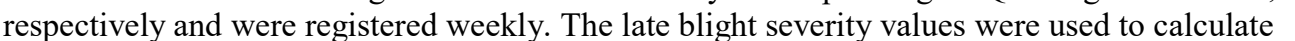

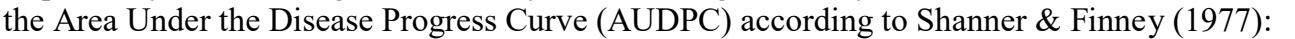

$\square$

$$
\begin{aligned}
& \text { AUDPC }=\sum\left[\left(Y_{\text {mint }}\right.\right.
\end{aligned}
$$

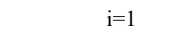


प

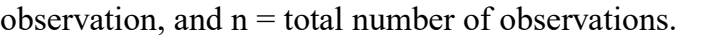

$\square$

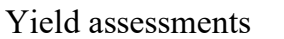

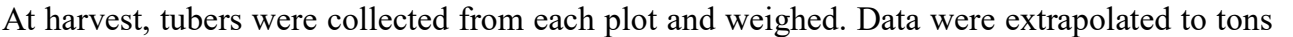

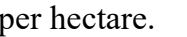

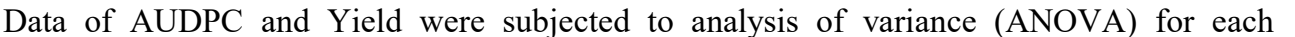

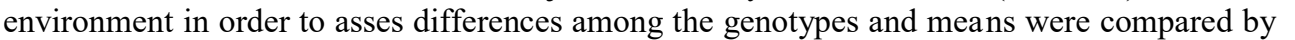

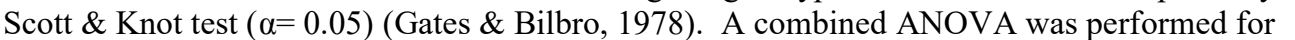
पाए।

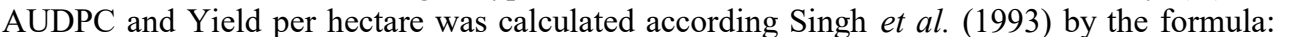

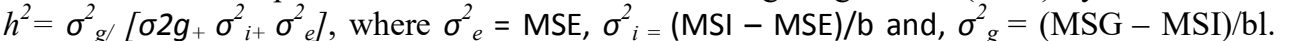

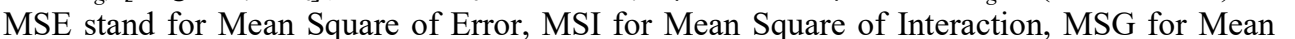

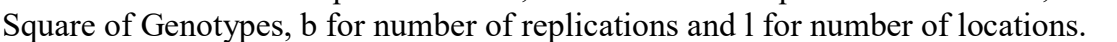

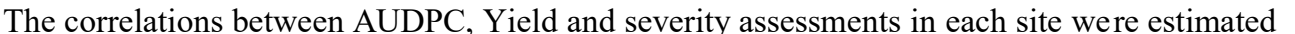

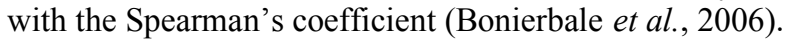

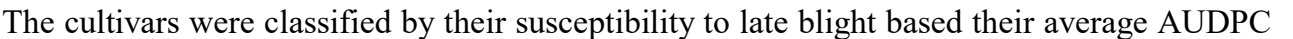

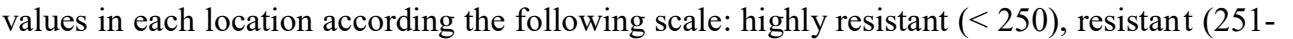

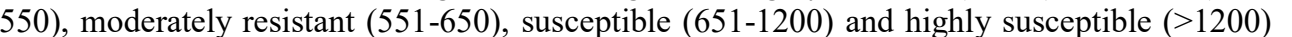

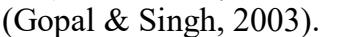

\section{Results and Discussion}

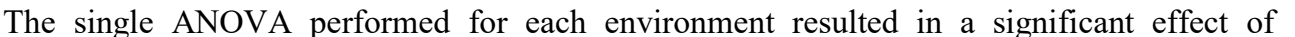

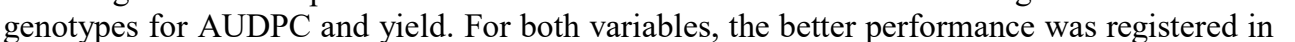

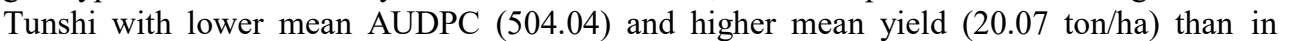

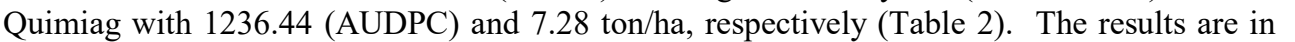

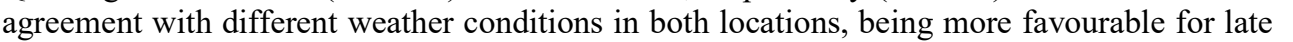

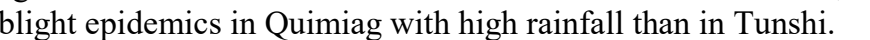

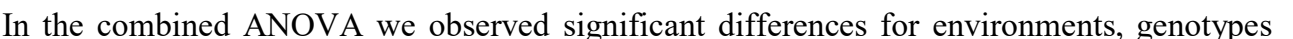

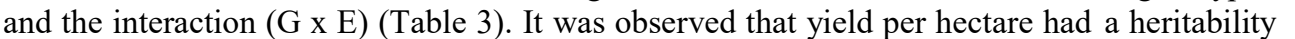

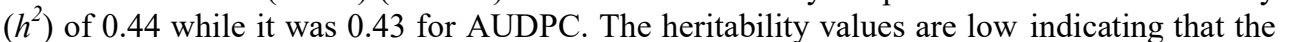

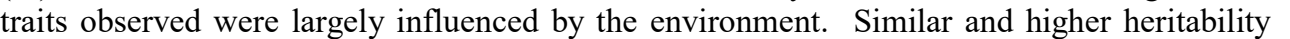

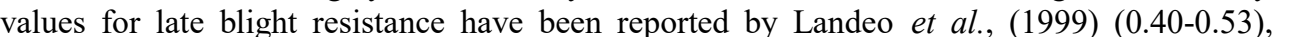

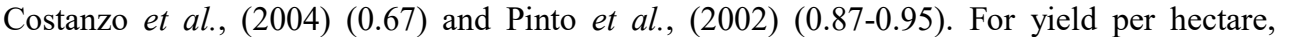

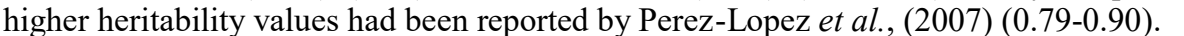

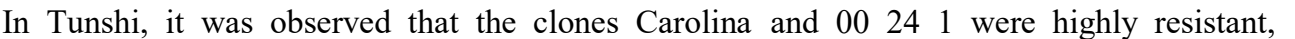

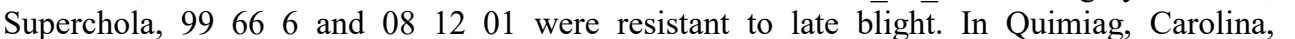

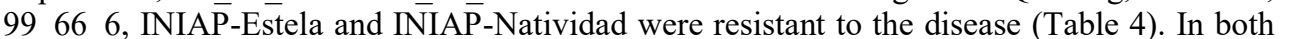

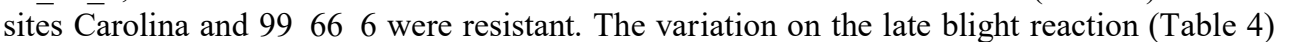

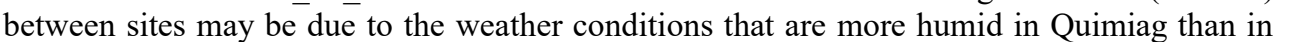




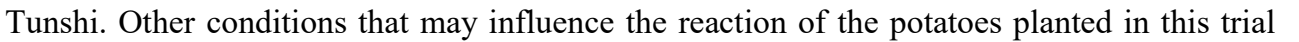

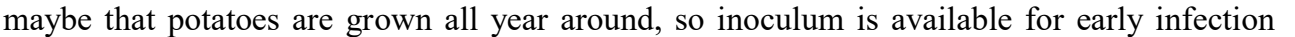

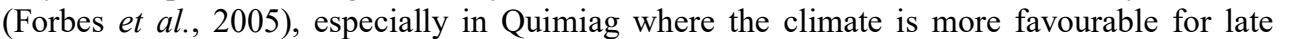

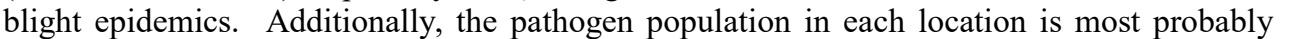

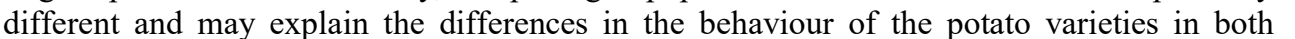

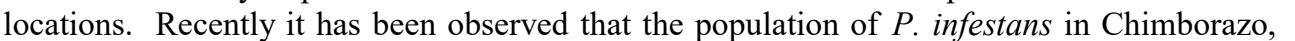

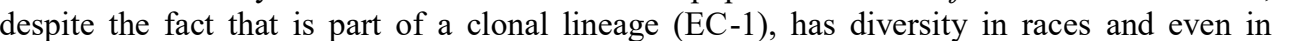

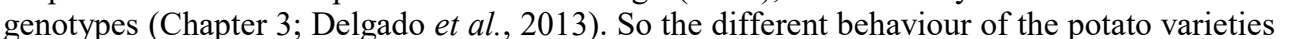

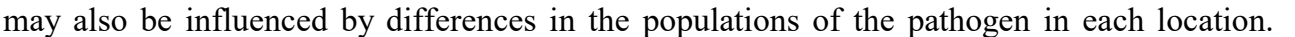

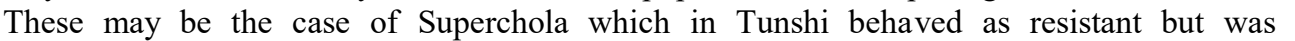

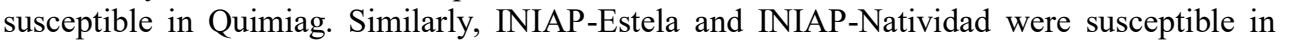

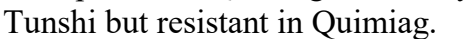

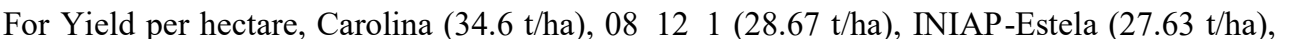

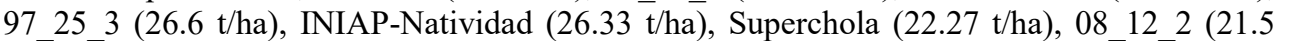

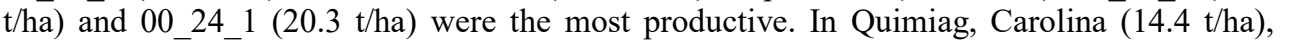

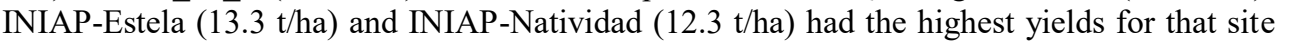
पापाणाणा

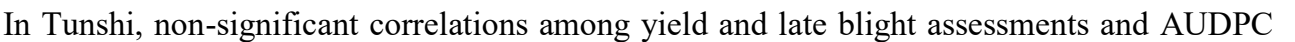

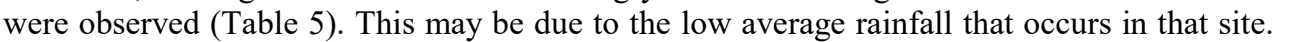

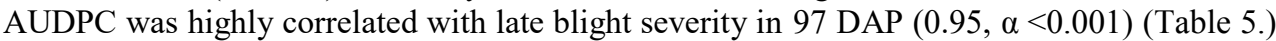

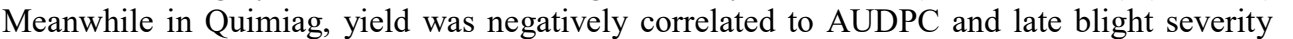

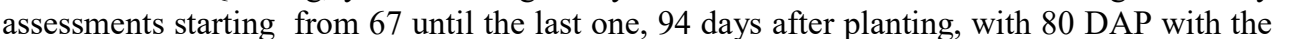

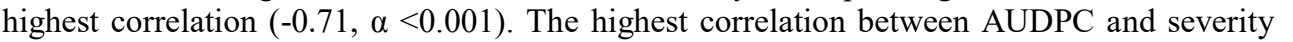

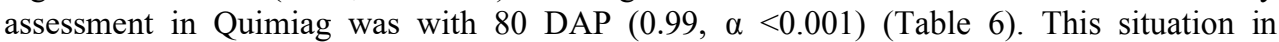

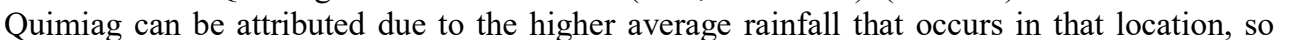

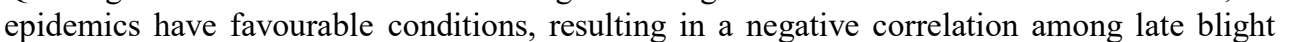
पाणाणाप

$\square$

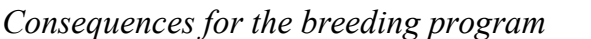

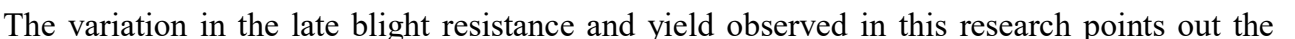

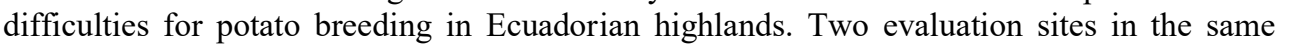

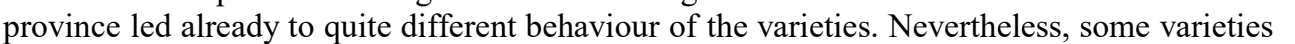

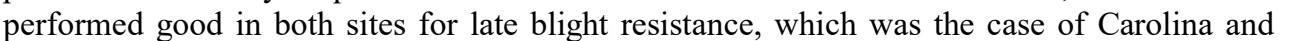

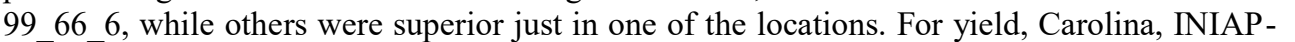

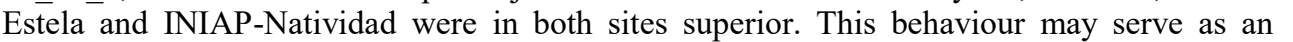

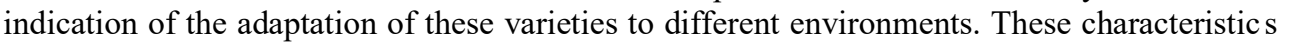

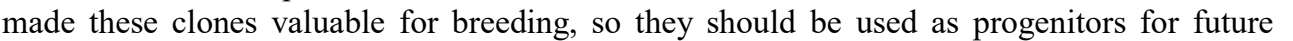

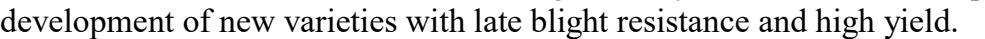

$\square$

\section{Acknowledgements}

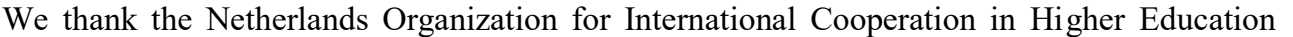

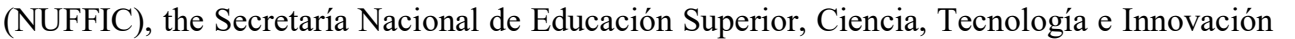

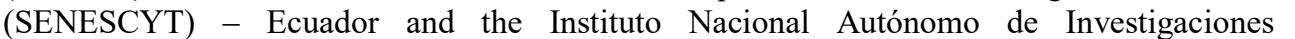

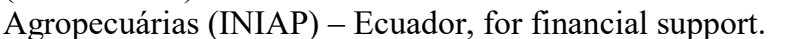




\section{Literature Cited}

$\square$

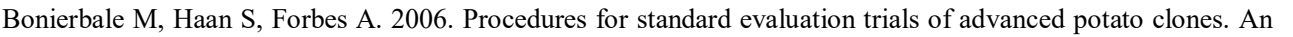
International Cooperators' Guide. Lima, Perú: International Potato Center (CIP). $\square$

$\square$

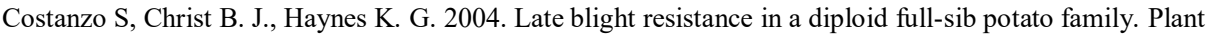

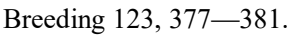

$\square$

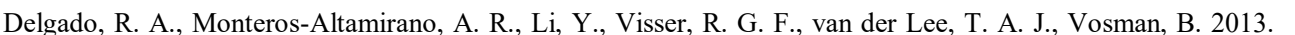

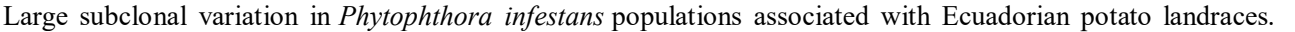

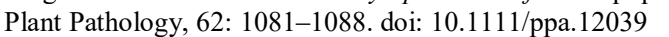

$\square$

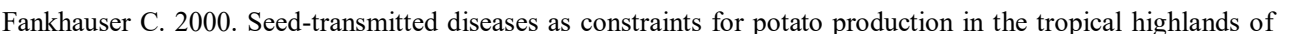

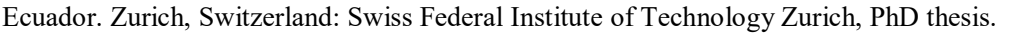
$\square$

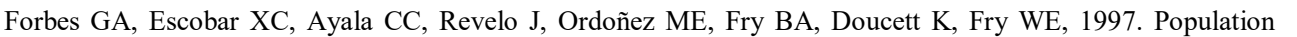

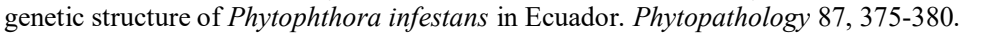
$\square$

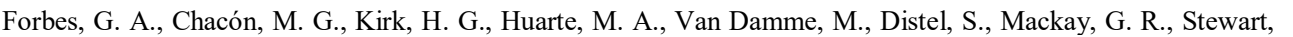
口

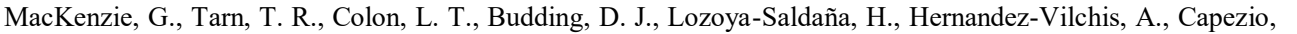

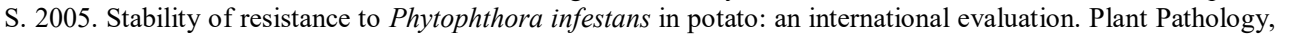

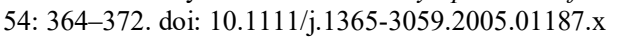
$\square$

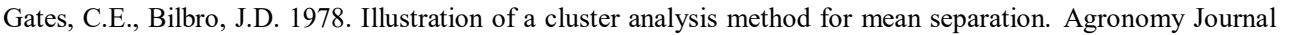

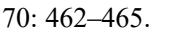

$\square$

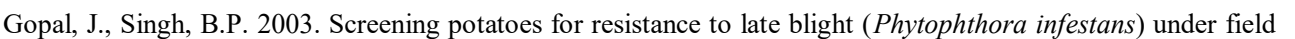

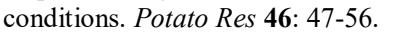
$\square$

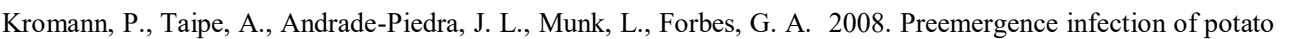

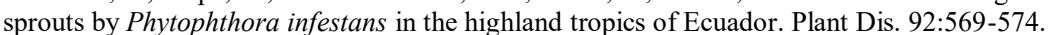
$\square$

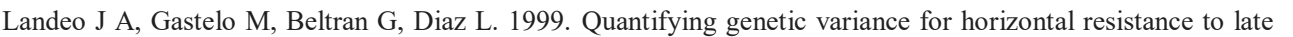

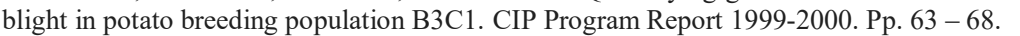
$\square$

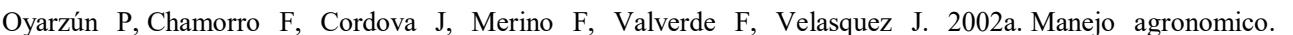

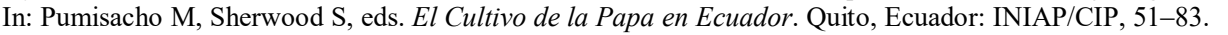
$\square$

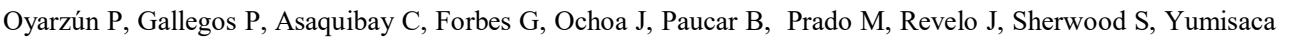

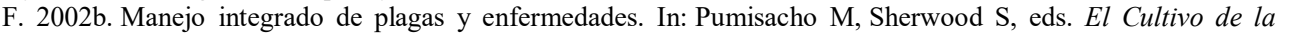

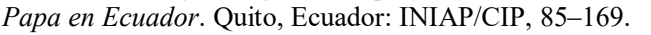
$\square$

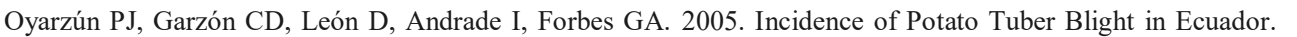

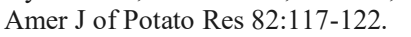
$\square$

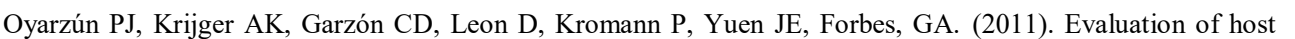
एரण

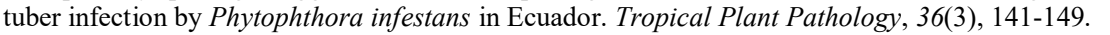
$\square$

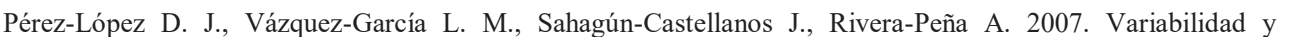

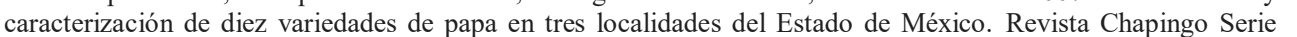

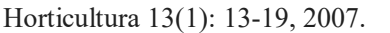

$\square$

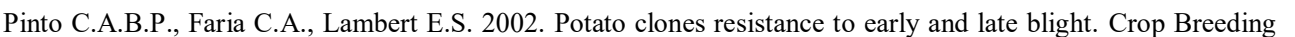

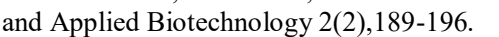

$\square$ 


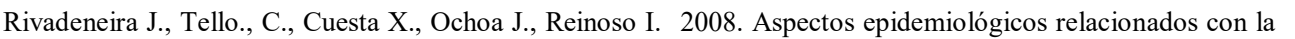

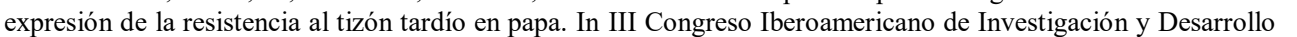

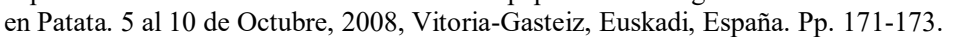

$\square$

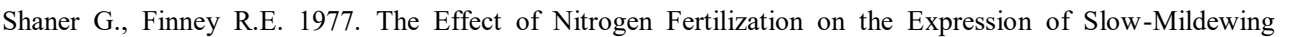

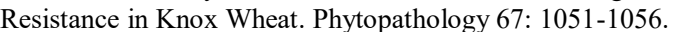

$\square$

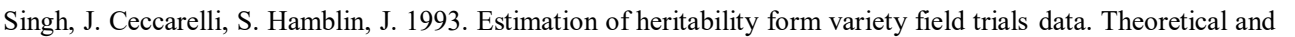

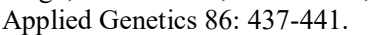

$\square$

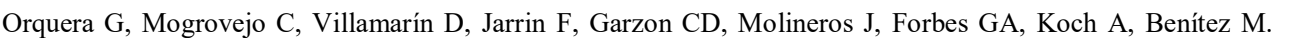

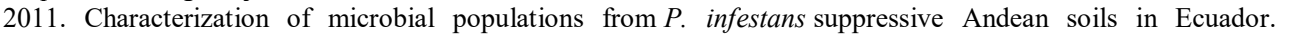

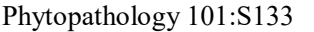

$\square$

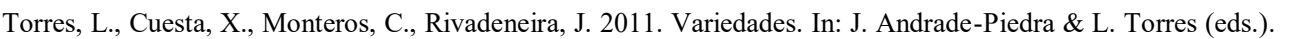

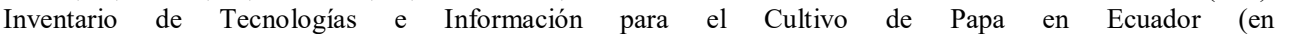

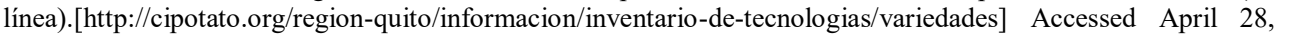
पामा $\square$

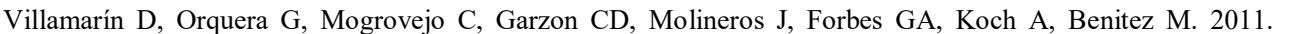

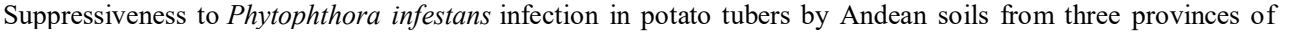

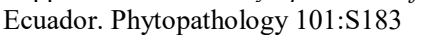




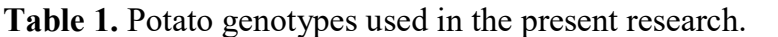

\begin{tabular}{|c|c|c|c|c|c|}
\hline Genotypes & Pedigree & Category & Origen $^{1}$ & $\begin{array}{l}\text { Skin } \\
\text { color }\end{array}$ & $\begin{array}{l}\text { Days to } \\
\text { maturit } \\
y\end{array}$ \\
\hline$\square\|\|\|\|$ & 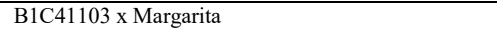 & $\begin{array}{l}\square \square 111111 \\
\square \| 11\end{array}$ & 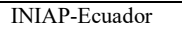 & 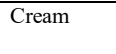 & $\square \square\|\| \| \square$ \\
\hline पापापा & 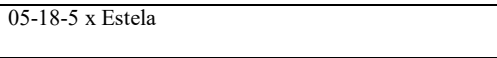 & 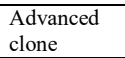 & 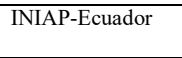 & 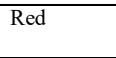 & $\square\|\|\|\|$ \\
\hline$\square|\square| \square \square$ & 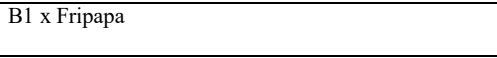 & 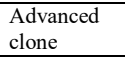 & 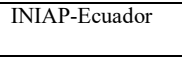 & 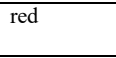 & $\square\|\|\|\| \square$ \\
\hline 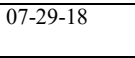 & 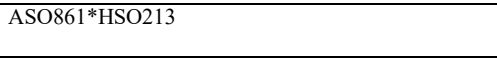 & 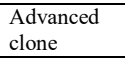 & 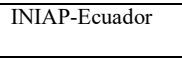 & 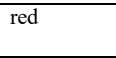 & $\square\|\|\|\| \square$ \\
\hline$\square 1 \square 1 \square \square$ & 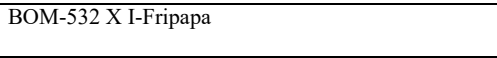 & 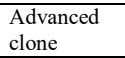 & 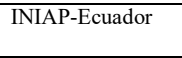 & 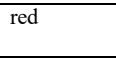 & $\square\|\| \| \square$ \\
\hline पा\|ापाप & 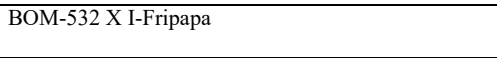 & 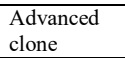 & 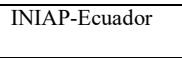 & 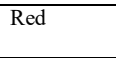 & $\square \square 1\|\| 1 \square$ \\
\hline पापापाप & 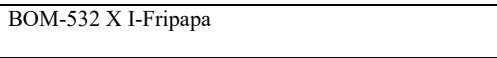 & $\begin{array}{l}\square \square 11111 \\
\square \square \| 11 \square \\
\end{array}$ & 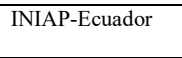 & 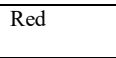 & $\square\|\|\|\| \|$ \\
\hline$\square\|\| 1 \|$ & 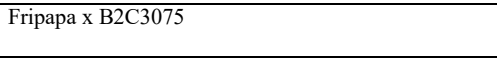 & 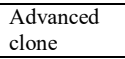 & 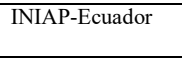 & 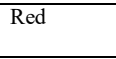 & $\square\|\|\|\|$ \\
\hline$\square\|\| 1 \| \square$ & 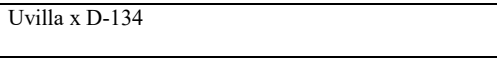 & 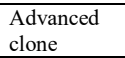 & 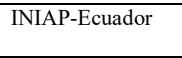 & 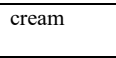 & $\square\|\|\|\| \square$ \\
\hline 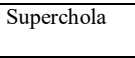 & 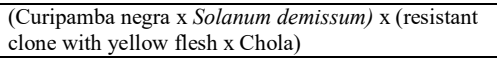 & 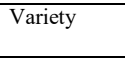 & 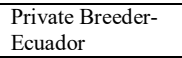 & 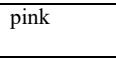 & $\overline{\square \square \square}$ \\
\hline 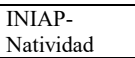 & 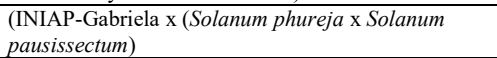 & 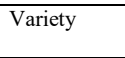 & 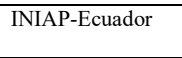 & 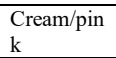 & $\square\|\| \| \square$ \\
\hline 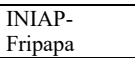 & | & 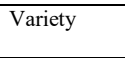 & 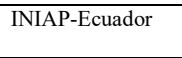 & 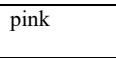 & $\overline{\square \square \square}$ \\
\hline 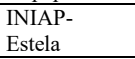 & 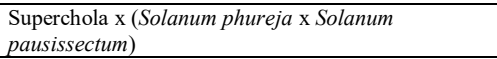 & पमाणाण & 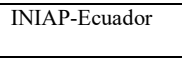 & पणमाणा & 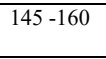 \\
\hline 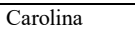 & 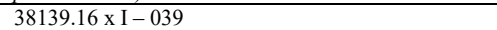 & 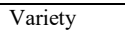 & 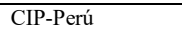 & 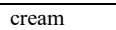 & 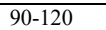 \\
\hline 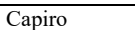 & 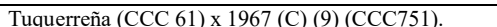 & पाणाणा & 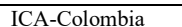 & $\pi$ & $2+18$ \\
\hline
\end{tabular}

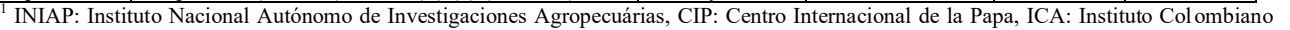
पाणाणाणाणाप

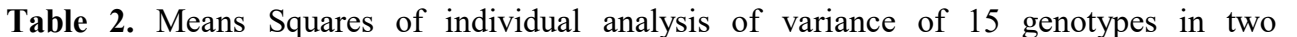

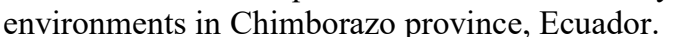

\begin{tabular}{|c|c|c|c|c|c|c|c|}
\hline \multirow{2}{*}{ 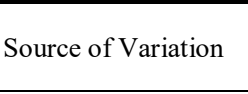 } & \multirow{2}{*}{ 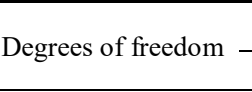 } & \multicolumn{4}{|c|}{ पिमपणि } & \multicolumn{2}{|c|}{ 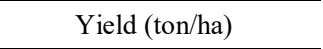 } \\
\hline & & \multicolumn{2}{|c|}{$\square \square\|\|\|\|$} & \multicolumn{2}{|c|}{ 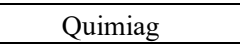 } & $\square \square\|\| \square$ & $\begin{array}{l}\square \square \square \square \\
\end{array}$ \\
\hline 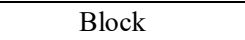 & $\square$ & 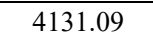 & पा\|ाII & 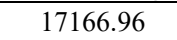 & $\mathrm{Q \square \| \textrm {II }}$ & 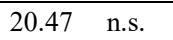 & $\overline{\square \square I I I I I I ~}$ \\
\hline 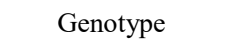 & $\square$ & पामापा & $* * *$ & $\square\|\|\|\| \square$ & $\square \square$ & $\square \Pi \Pi \square \square$ & $\square \square \square \square \square$ \\
\hline 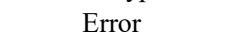 & $\square \square$ & $\square\|\| \square$ & $\sqsubset$ & $\square\|\| \| \square$ & $\sqsubset$ & $\square \Pi \square$ & $\square \square \square$ \\
\hline$\square \square \square$ & $\square$ & 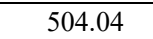 & $\bar{\square}$ & 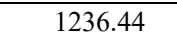 & $\bar{\square}$ & 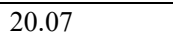 & $\square \square$ \\
\hline$\square \square \square \square \square$ & $\square$ & $\square \square \square$ & $\sqsubset$ & $\square \Pi 1$ & $\sqsubset$ & $\square \square \square$ & $\square \square \square$ \\
\hline
\end{tabular}

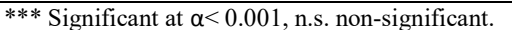

$\square$ 


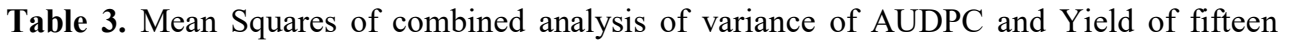

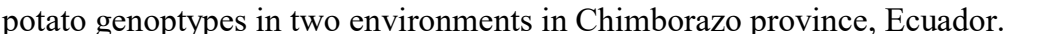

\begin{tabular}{|c|c|c|c|c|c|}
\hline 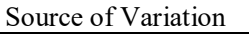 & 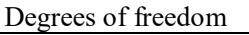 & 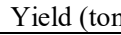 & IIIIU & \multicolumn{2}{|c|}{$\begin{array}{l}\square \square \square \square \square \\
\end{array}$} \\
\hline 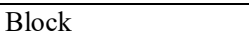 & $\square$ & $\square \square$ & 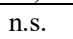 & 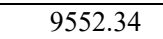 & $\overline{\square \square\|ा\|}$ \\
\hline 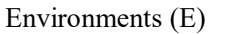 & $\square$ & $\square \| \Pi$ & $* * *$ & $\square\|\|\|\| \square$ & $* * *$ \\
\hline 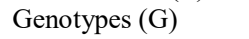 & $\square$ & $\square \| \square$ & $* * *$ & $\square\|\|\|\| I$ & $* * *$ \\
\hline पषाप्ण & $\square \square$ & पाएा & $*$ & $\square\|\| \| \square$ & $* * *$ \\
\hline 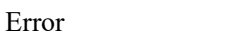 & $\square$ & पणा & $\sqsubset$ & 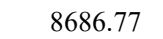 & ६ \\
\hline$\square \square \square \square$ & $\square$ & पणा & $\sqsubset$ & $\square \| \square$ & ६ \\
\hline$\square \square \mathbb{1 0}$ & $\square$ & $\square \square \square$ & ᄃ & $\square \square \square$ & ६ \\
\hline
\end{tabular}

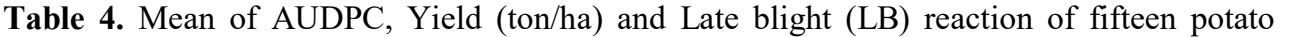

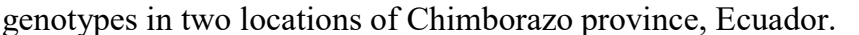

\begin{tabular}{|c|c|c|c|c|c|c|c|c|c|c|c|}
\hline \multirow{2}{*}{ पणाणाणा } & \multicolumn{5}{|c|}{ 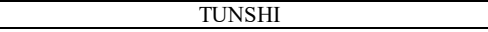 } & \multicolumn{6}{|c|}{ 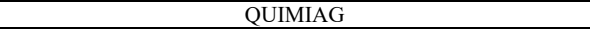 } \\
\hline & & 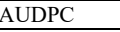 & & 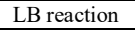 & 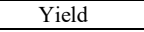 & & 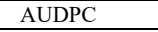 & & 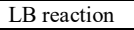 & & पणाप \\
\hline 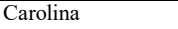 & $\square \square$ & 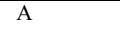 & & 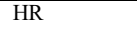 & 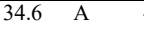 & $\square \square$ & $\square \llbracket$ & & $\square \square \square$ & पाIII & \begin{tabular}{l|l|} 
\\
\end{tabular} \\
\hline$\square 111111 \mathrm{~m}$ & पाए & 吅 四 孟 & & प्० & पणा पए & पापाप & 四 四 $\square[$ & & $\square$ & एणा & ] 四 $\mathbb{I I}$ \\
\hline पा1णमाणा & पाणा & 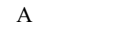 & & 口प & पाणा पा & पाणाए & 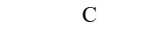 & & $\square$ & $\square$ & 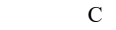 \\
\hline$\square 1111111 \mathrm{~m}$ & पाणा & ㅁㅁ 四 正 & & $\square \square$ & 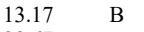 & $\square \square$ & पा & & $\square \square$ & पाणा & ] 四 正 \\
\hline$\square 111111 \mathrm{~m}$ & पणाप & 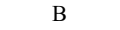 & & $\square \square$ & पणा पर & $\square П$ & 四 口प & & $\square \square$ & एवाए & 四 吅 \\
\hline 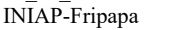 & पाणा & I 四 & & व०० & 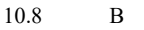 & प पाणा & 四 四 四 & 口प & प्रा & पाण & ，四 而口 \\
\hline प1111110 & Шाण & 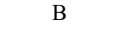 & & प०० & 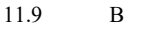 & प पाए & पष & & $\square \square \square$ & एणाए & ] 四 正 \\
\hline 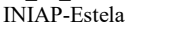 & पाणा & 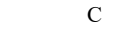 & & ००० & पाणा पा & प110ा & $\square \llbracket$ & & $\square \square$ & पIIII & I ०० \\
\hline प1111111 & पाए & 四 四 & & १०० & 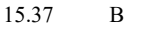 & प पाणा & 四 口प & & $\square \square$ & पाणा & 四 \\
\hline யாாயாயாய & पाणा & ，四 四 & & १०० & पणाप प्रा & $\square \square$ & 口ा & & १०० & पाII & I पि \\
\hline प11ा1एाய & $\square ए$ & 四 四 प्रा & & १०० & एणा पर & पाயप & 四 四 & & $\square \square$ & एणा & 西 正 \\
\hline$\square 11111 \mathrm{~m}$ & पाणा & 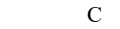 & & ज०० & एणा पर & पापाप & 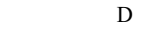 & & $\square \square \square$ & पाIए & 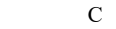 \\
\hline पणामाणा & पाणा & ，四 四 & I पा म & $\square$ & 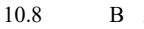 & पाणा & - & 世ा1 & $\square \square \square$ & पाणा & 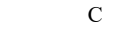 \\
\hline$\square 111111 \mathrm{~m}$ & Шा & 四 四 正 & I पा म & $\square$ & 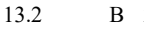 & पाणाप & 四 四 $\mathbb{U}$ & $\square$ & $\square \square \square$ & एवाए & ] 四 正 \\
\hline$\square 111111 \mathrm{MU}$ & $\square 1 \| \square$ & 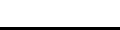 & 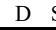 & $\square$ & 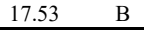 & $\square \square 1 \| ण I$ & 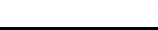 & $\square[$ & $\square \square \square$ & $\square|l|$ & 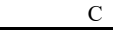 \\
\hline$\square \square \square$ & $\square\|\| \square$ & {$[\mathbb{\square} \square$} & II & 四 & 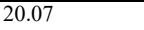 & $\square 11\|\|$ & $\mathbb{\square} \square \mathbb{\square}$ & $\mathbb{\square}$ & $\mathbb{\square}$ & $\square$ & $\mathbb{\square} \square \square$ \\
\hline 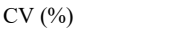 & $\square ण I$ & 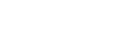 & 四 & 四 & $\square \| \square \mathbb{~} \square$ & पणा & 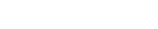 & $\mathbb{1} \mathbb{U}$ & 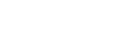 & $\square$ & 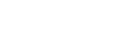 \\
\hline
\end{tabular}




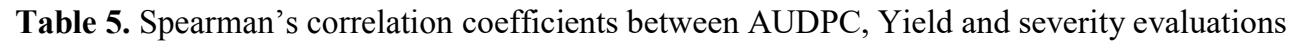

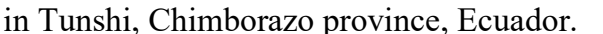

\begin{tabular}{|c|c|c|c|c|}
\hline पा\|ा\|ा & $\square \| \square \square \square \square$ & $\square 111$ & $\square 1 \| \square$ & 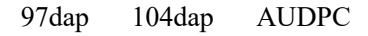 \\
\hline$\square П \square$ & & & & \\
\hline पापाप्य & पापाणा & & & \\
\hline 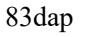 & एणाप पणाए & & & \\
\hline पाएाய & एणाणा घणाण & पणाण & & \\
\hline$\square П 1$ & एणाய पणाप & पणाण & पणाणाए & \\
\hline पाया & पणाणा पणापाप & पणाणाण & पणाणाप & पणाणाप \\
\hline 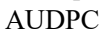 & पणाणा पणाण & पणाणाण & पणाणा & पणापा एणापा \\
\hline पणाणाए & पणाणा घणाणाय & एणाणामा & एाणाणाण & 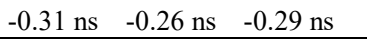 \\
\hline
\end{tabular}

Table 6. Spearman's correlation coefficients between AUDPC, Yield and severity evaluations

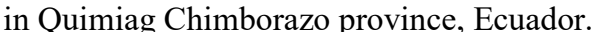

\begin{tabular}{|c|c|c|c|c|c|c|c|c|c|}
\hline 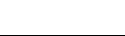 & $\square\|\|$ & $\square \| \square$ & $\square\|\|$ & $\square 1110$ & $\square 111 \square$ & $\square 11110$ & $\square 1110$ & प1口卄110 & 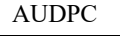 \\
\hline \multicolumn{10}{|l|}{$\overline{\square 111 \square}$} \\
\hline एाए & पणाण & & & & & & & & \\
\hline$\square 110$ & पणाणाए & पणाण & & & & & & & \\
\hline एणा & पणाण & पणाण & पण口ण & & & & & & \\
\hline$\square \amalg \square$ & पणमाण & एणाए & एणाण & मणाण & & & & & \\
\hline एाएा & पणाणाण & एणाणाण & एणाயण & पणाणा & पणाणाए & & & & \\
\hline पाएप & पणाणाए & एणाण & एणाणए & पण口ण & पण口ण & पणाणाए & & & \\
\hline पापाए & पणाणाए & एणाणाण & एणाणए & पणाण & पणाण & एणाण & एणाणाए & & \\
\hline प्रणपा & पणाणाए & पणाण & एणाणा & पणाणा & पणाणाए & पणाणाम & एणाणाए & एणाणाए & \\
\hline प्णाणा & एवाणाए & एणाயण & एणाшाण & एण口卄ाण & एणाण & வாயாம & एण口冋 & एणाण & पण口卄ा \\
\hline
\end{tabular}

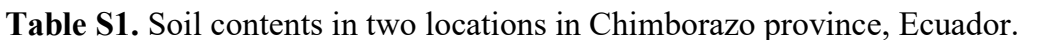

\begin{tabular}{|c|c|c|}
\hline $\mathbb{\square}$ & $\square \square \square \square$ & $\square \square\|\| \|$ \\
\hline 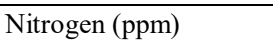 & $\square$ & $\square \square$ \\
\hline 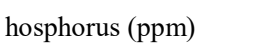 & $\square \square$ & $\square$ \\
\hline 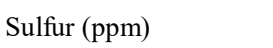 & पाए & $\square \square$ \\
\hline 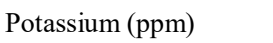 & पाए & $\square$ \\
\hline 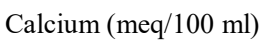 & पाण & $\square \square$ \\
\hline 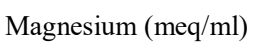 & पणा & $\square \square$ \\
\hline$\square \square$ & पणम & $\square \square$ \\
\hline 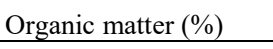 & $\square \square$ & $\square \square$ \\
\hline
\end{tabular}




\section{Chapter 8}

\section{General Discussion}

$\square$

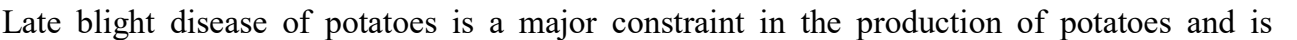

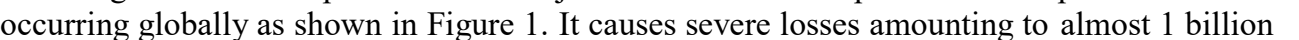

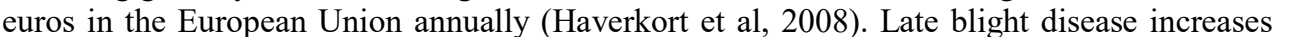

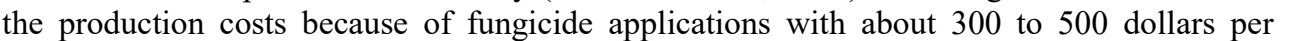
பாயா

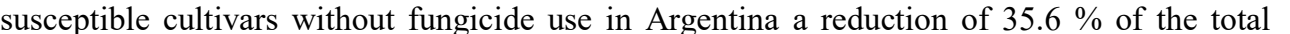

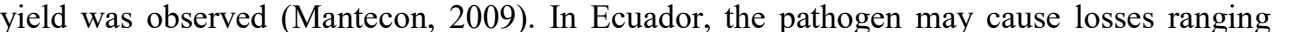

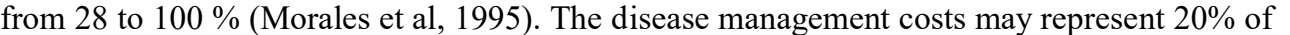

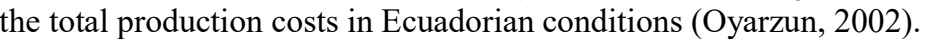

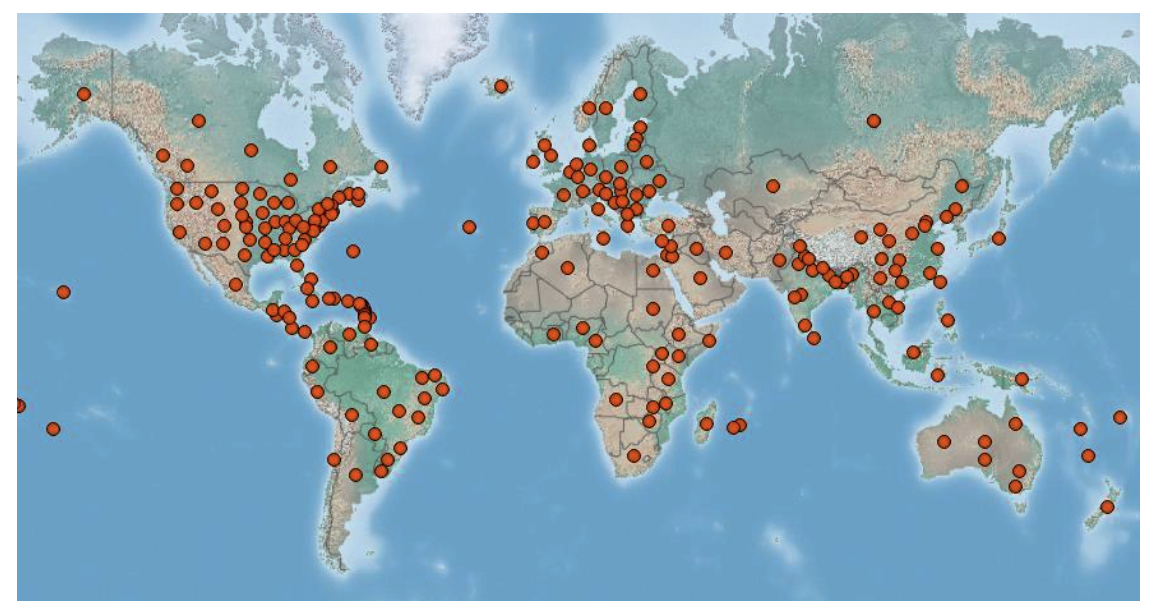

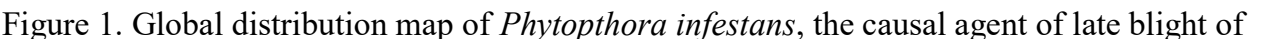

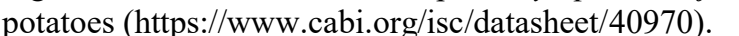

$\square$

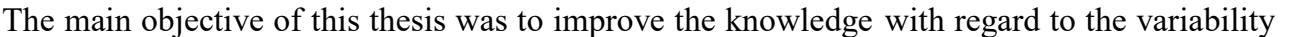

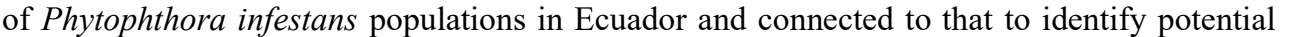
ए एव

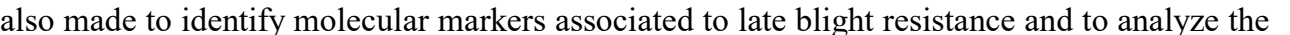

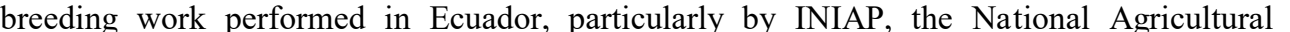

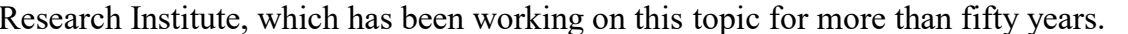

$\square$

\section{Late blight resistance}

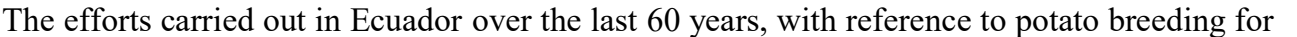

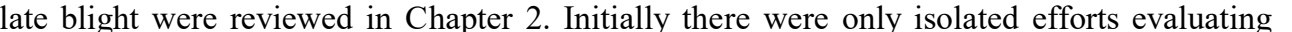




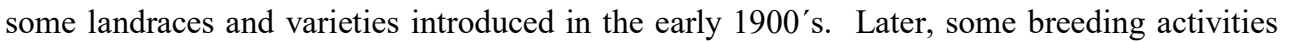

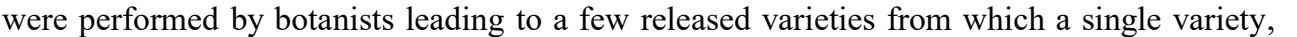

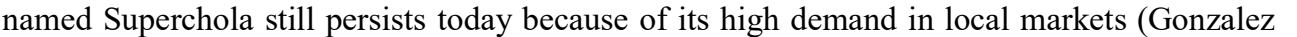

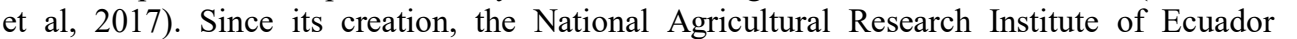

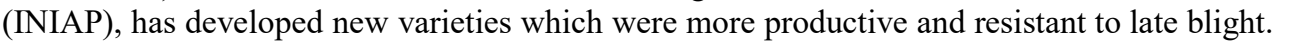

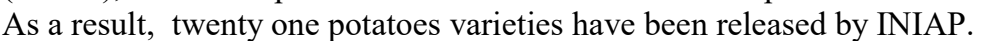

$\square$

$\square$

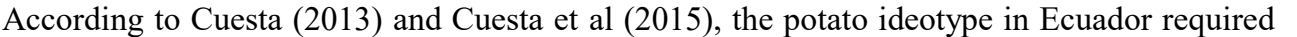

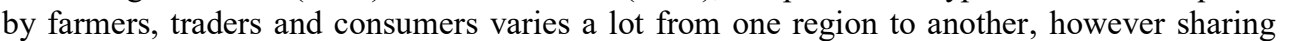

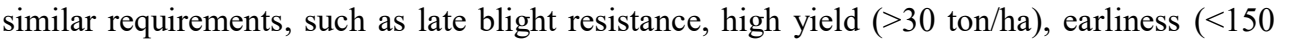

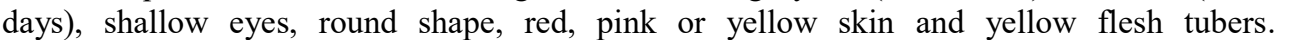

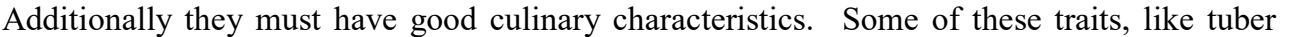

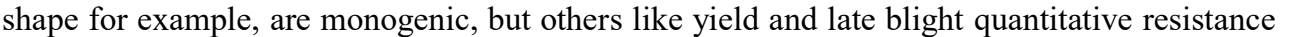

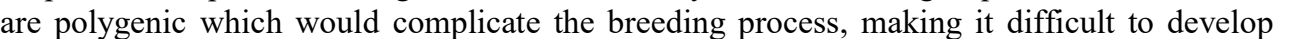

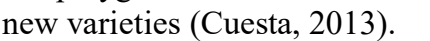

$\square$

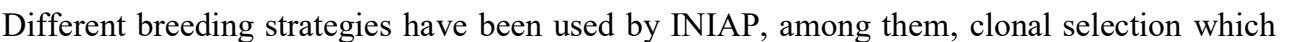

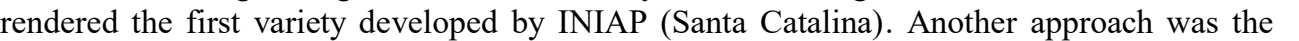

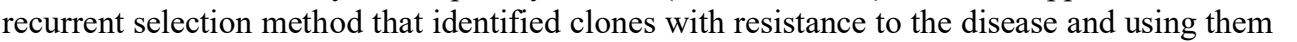

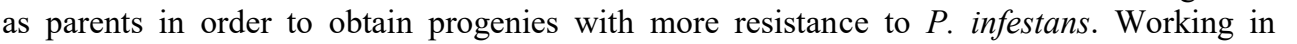

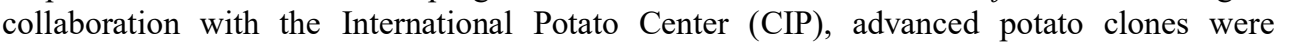

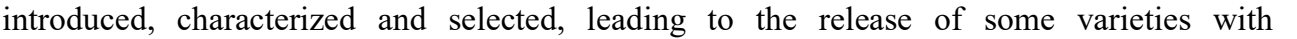

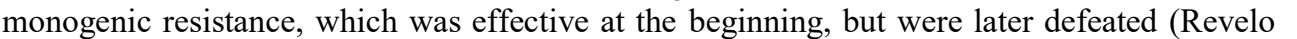

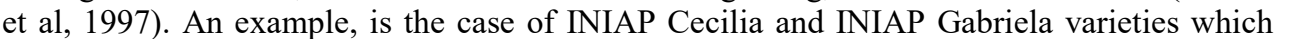

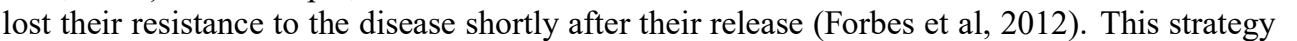

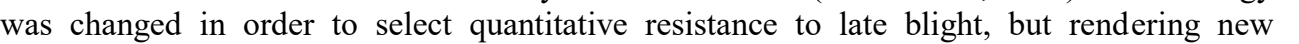

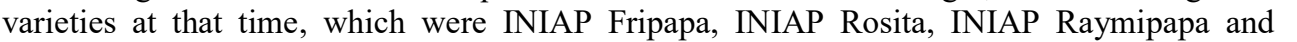

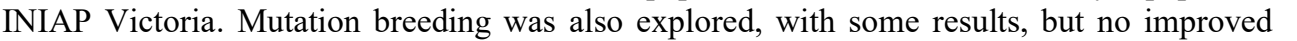

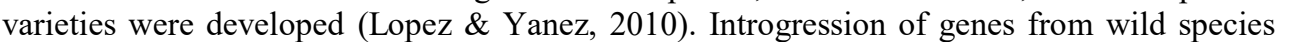

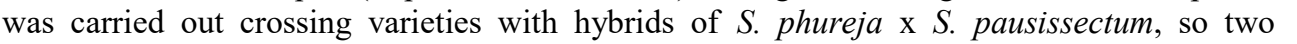

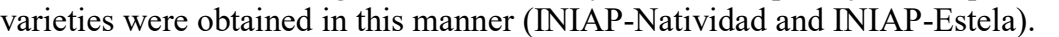

$\square$

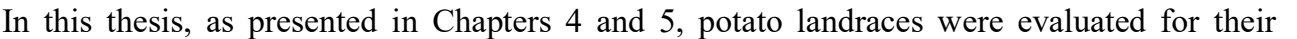

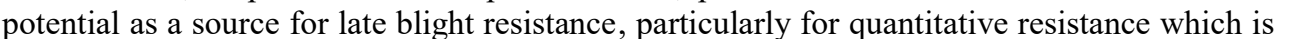

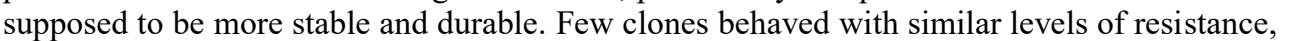

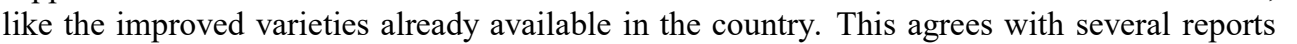

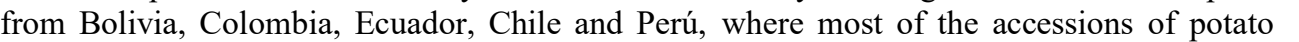

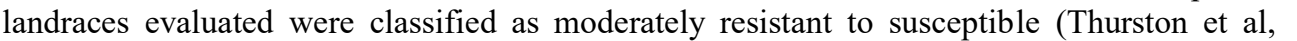

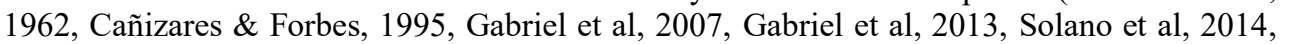

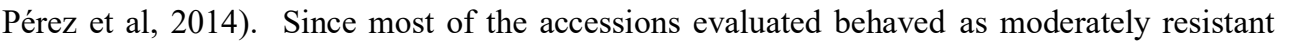

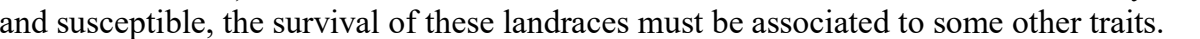

$\square$

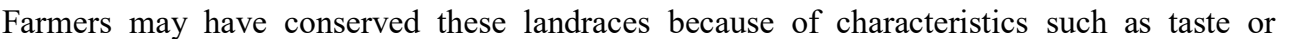

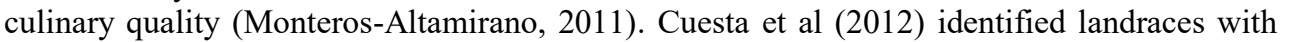




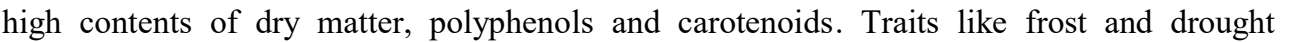

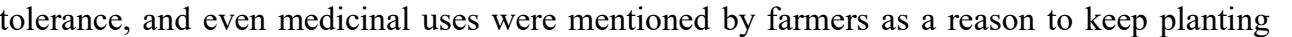

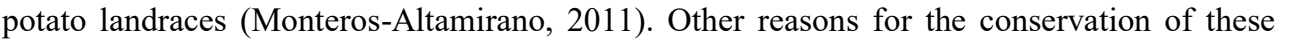

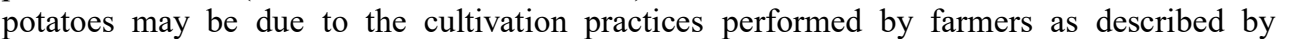

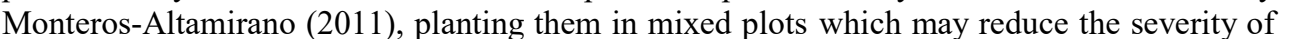

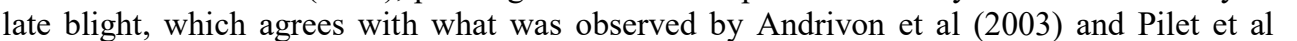

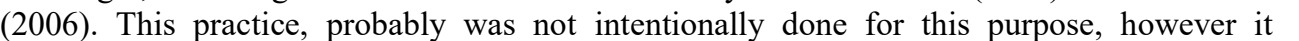

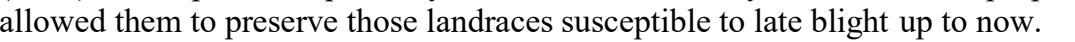

$\square$

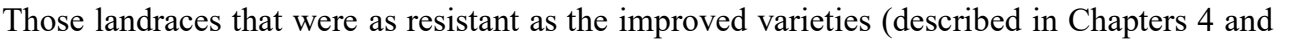

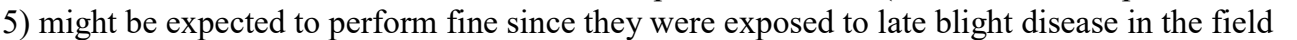

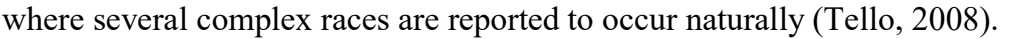

$\square$

\section{Pathogen variability}

$\square$

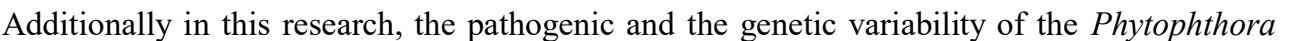

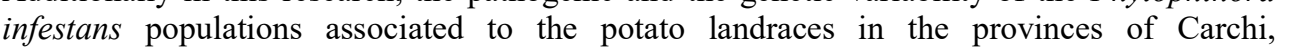

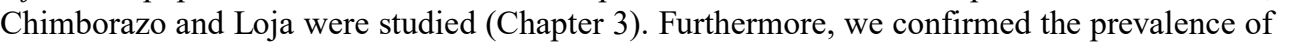

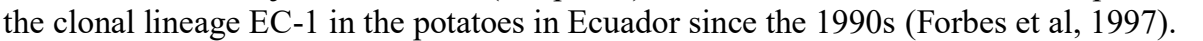

$\square$

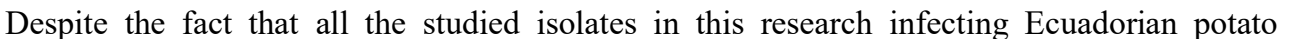
ए ए।

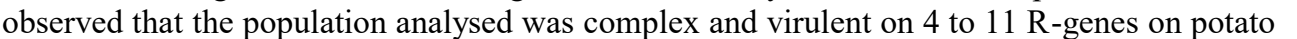

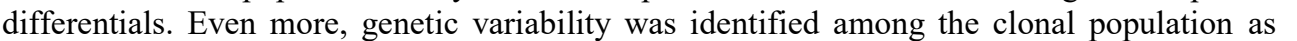

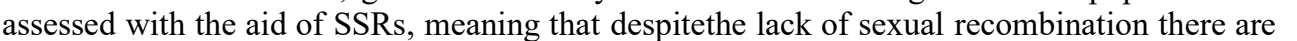

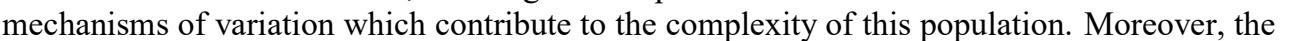

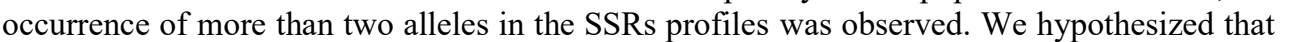

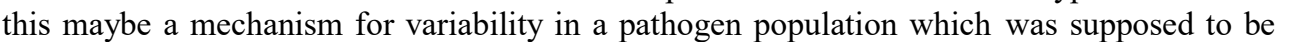

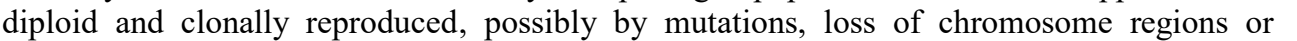

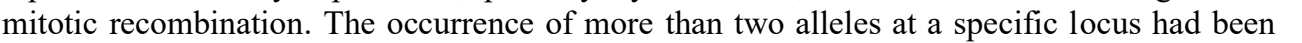

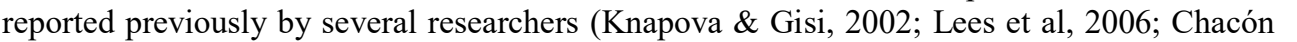

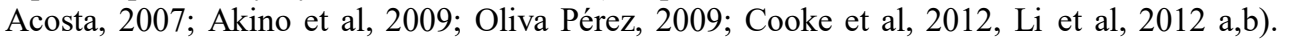

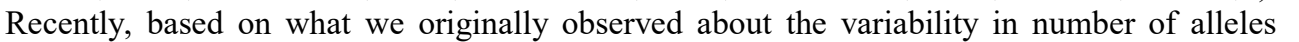

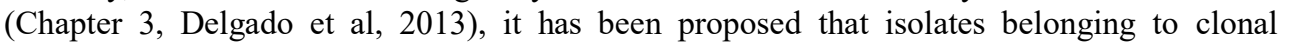

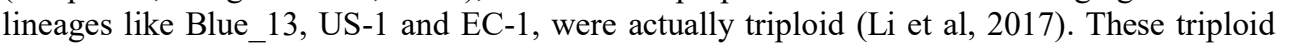

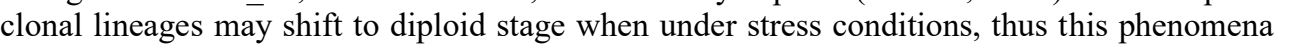

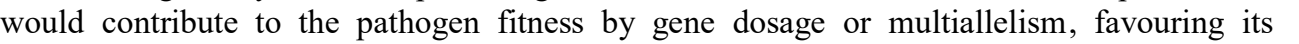

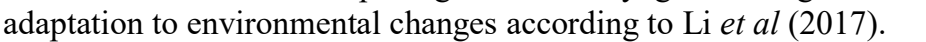

$\square$

$\square$

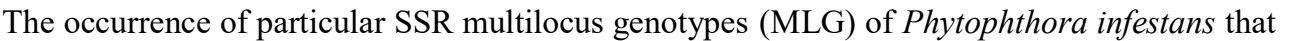

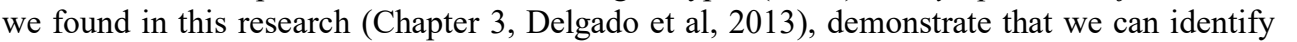

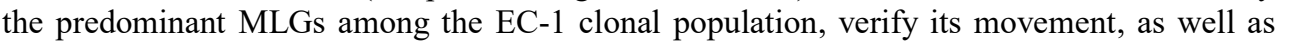

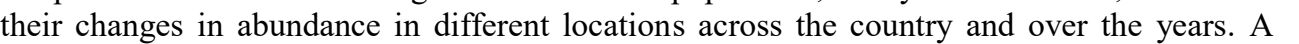




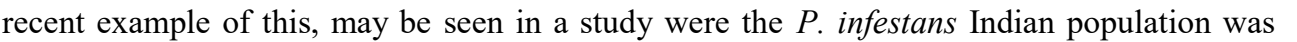

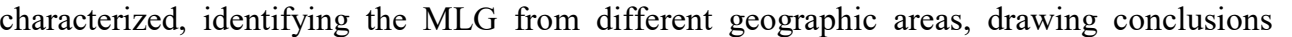

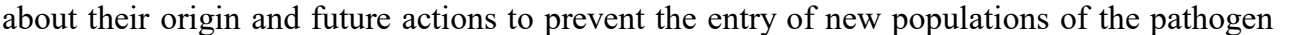

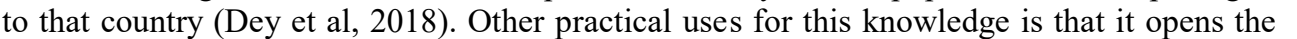

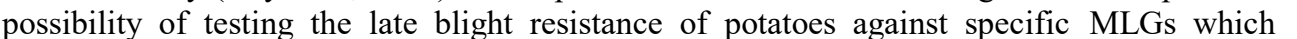

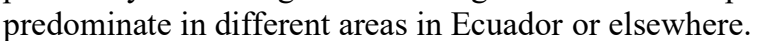

$\square$

\section{Perspectives for late blight resistance breeding in Ecuador}

$\square$

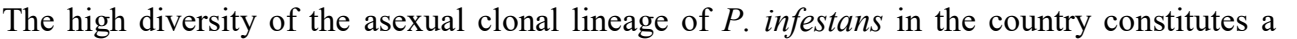

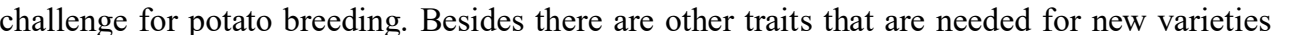

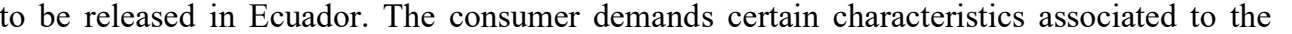

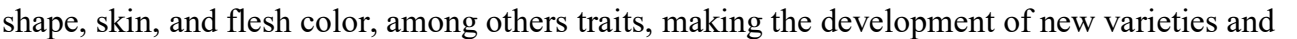

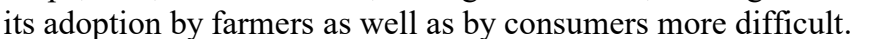

$\square$

$\square$

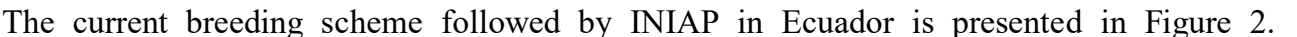

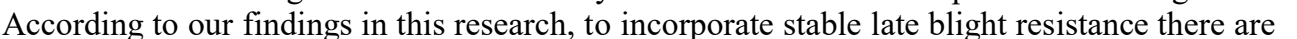

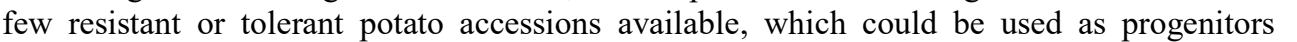

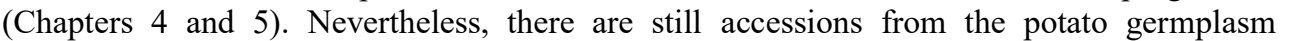

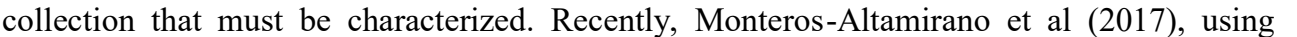

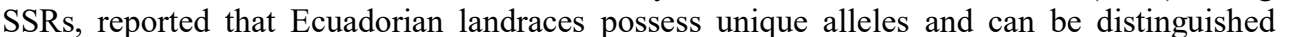

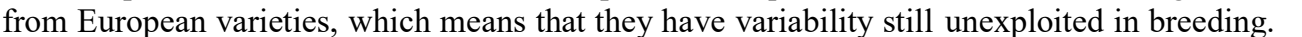

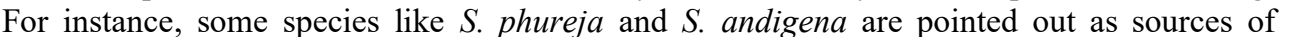

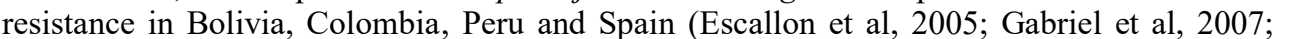

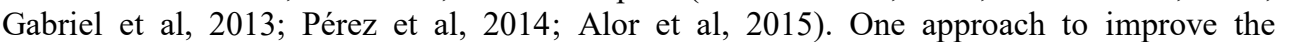

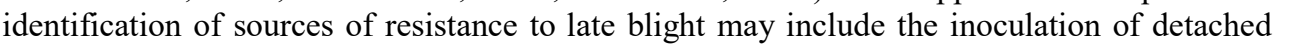

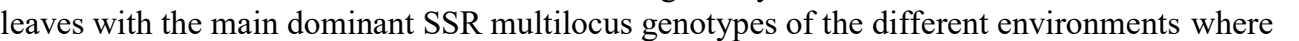

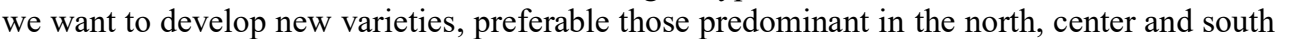

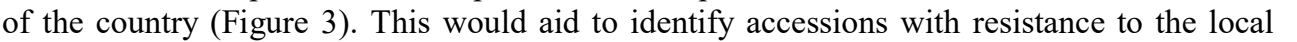

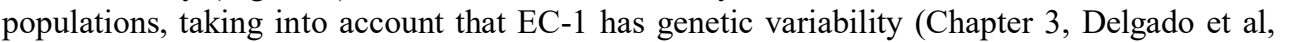

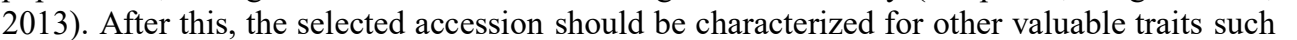

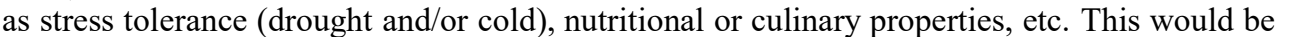

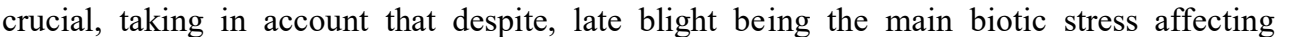

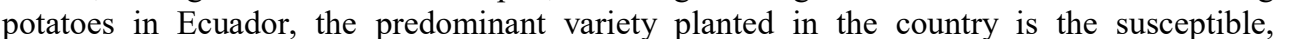

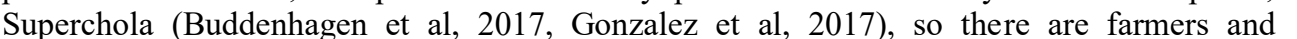

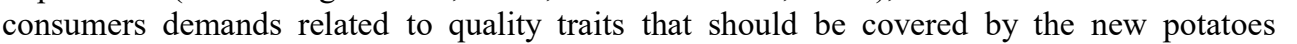

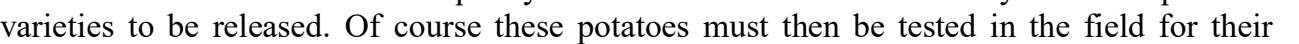

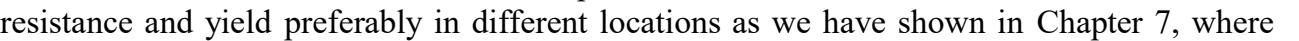

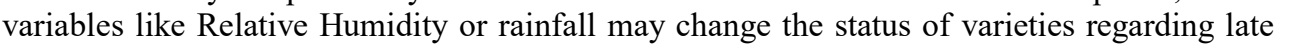

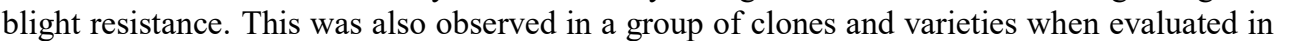

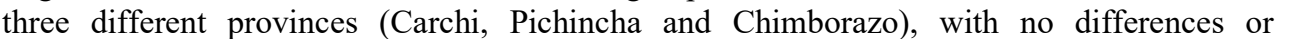

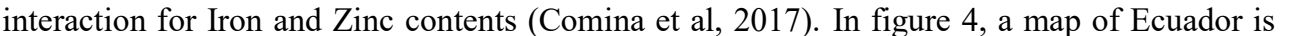

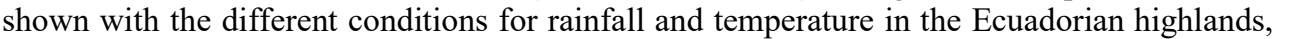

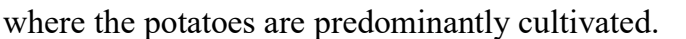

$\square$ 


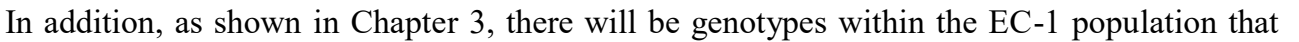

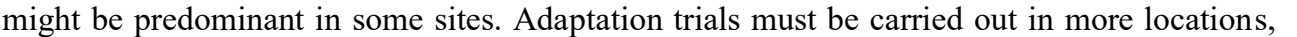

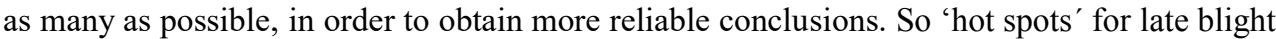

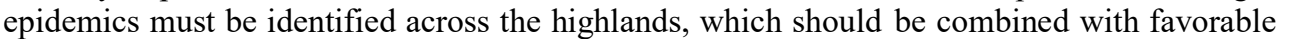

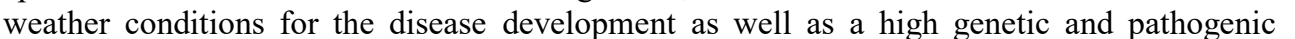

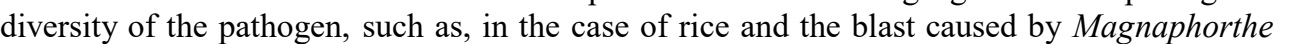

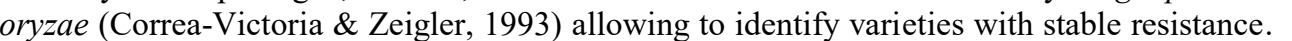

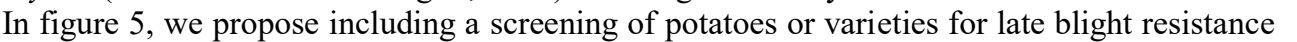

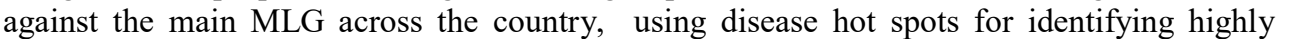

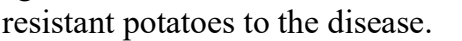

$\square$

$\square$

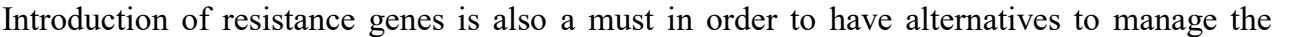

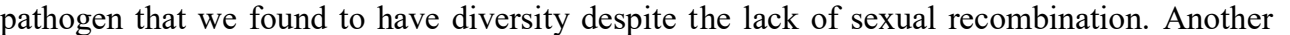

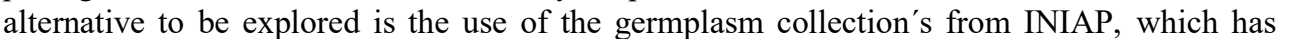

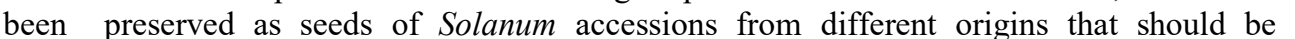

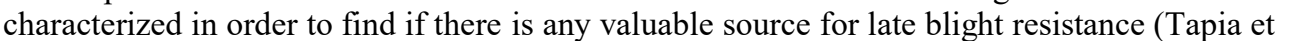

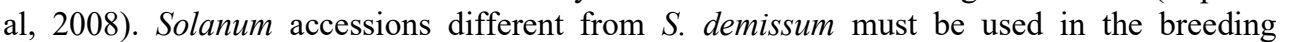

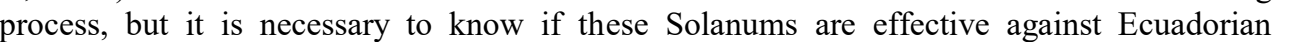

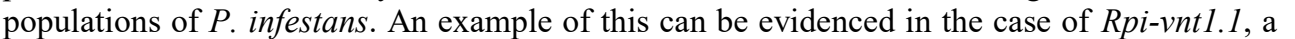

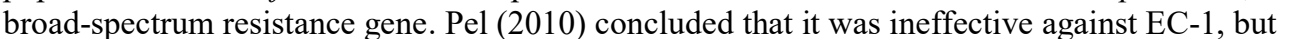

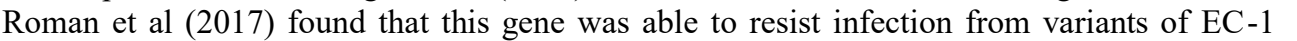

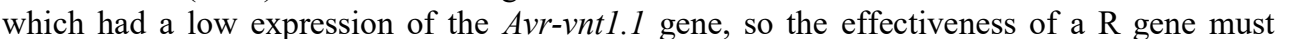

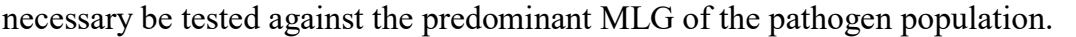

$\square$

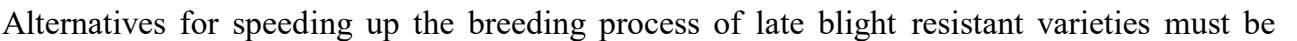

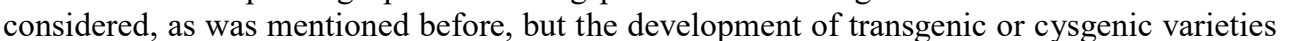

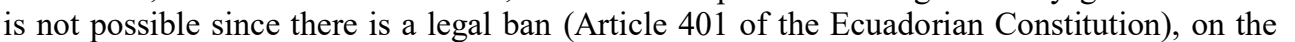

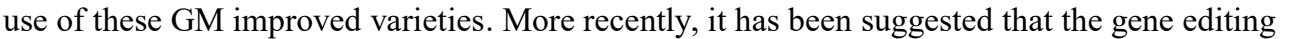

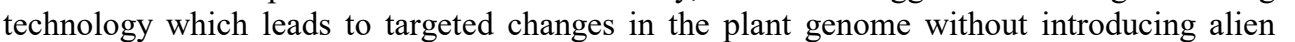

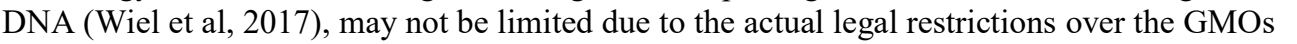

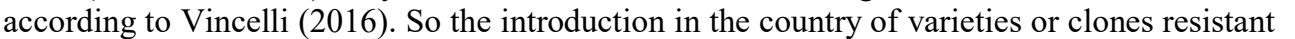

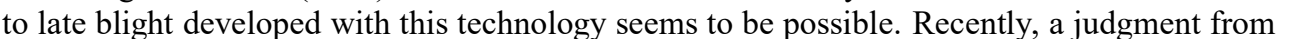
प

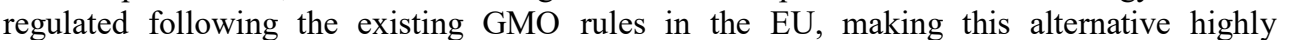
पाणाणाण

$\square$

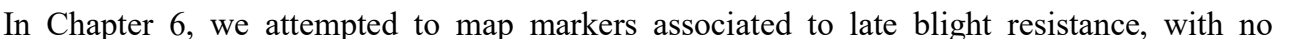

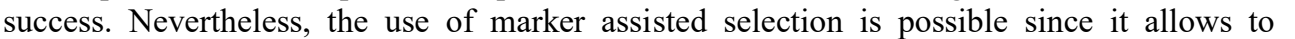

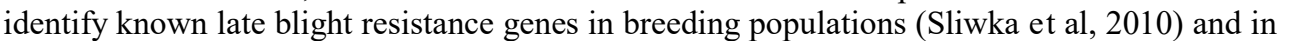

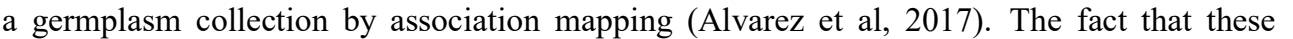

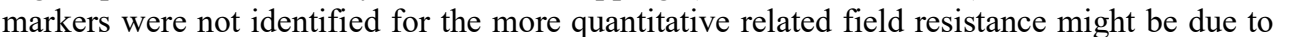

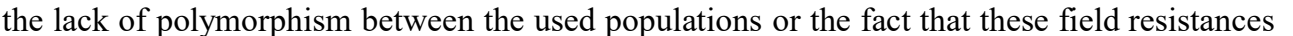

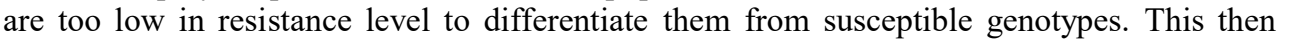

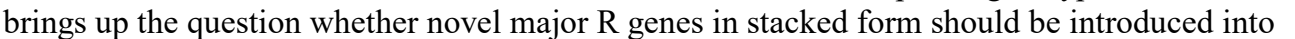

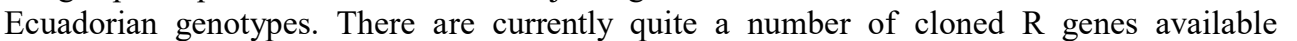




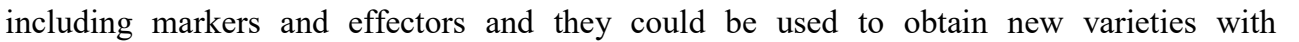

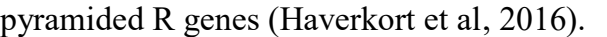

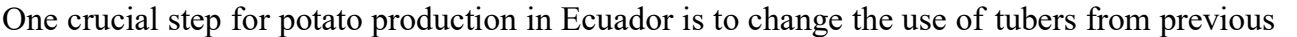

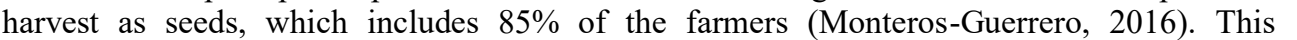

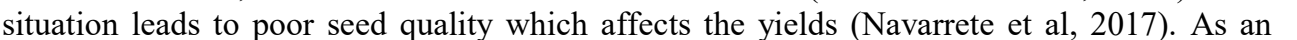

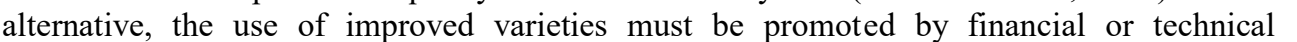

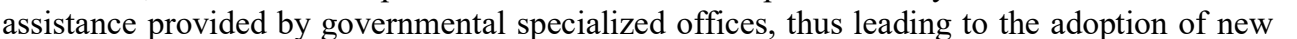

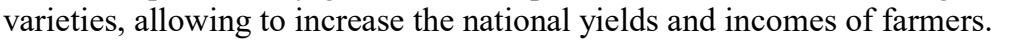

$\square$

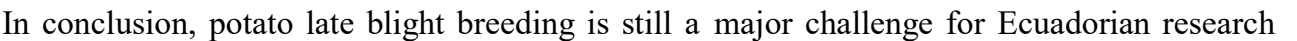

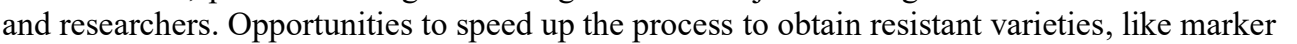

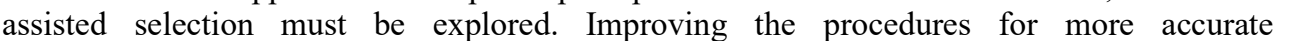

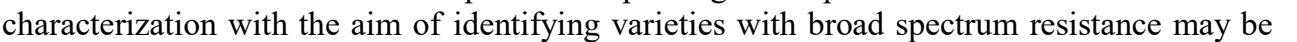

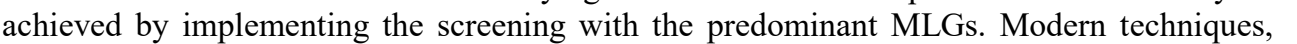

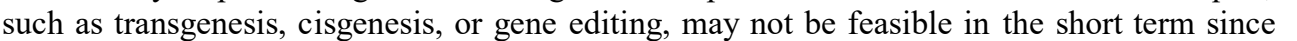

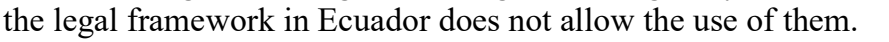




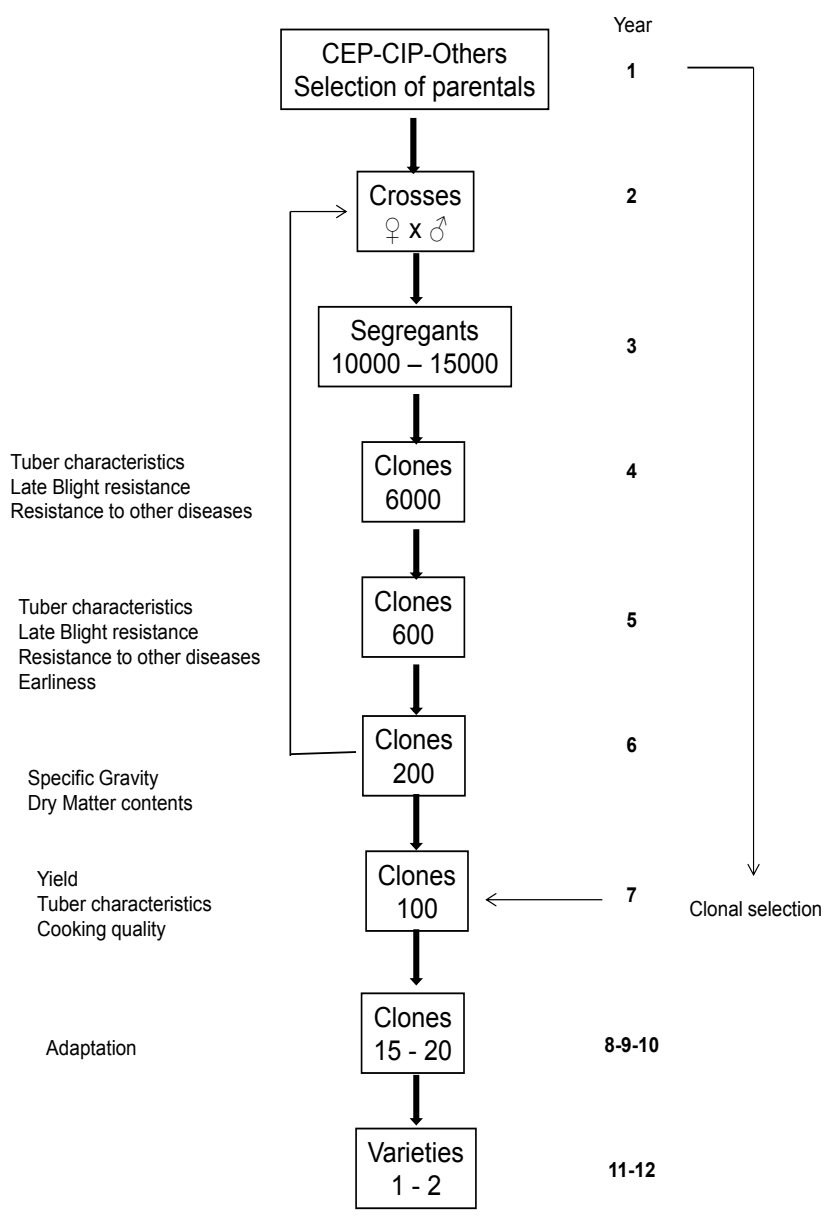

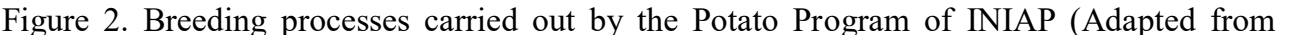

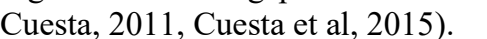




\begin{tabular}{|c|c|c|c|}
\hline \multirow{2}{*}{ Accessions } & \multicolumn{3}{|c|}{ Multilocus Genotypes } \\
\cline { 2 - 4 } & North & Center & South \\
\hline 1 & & & \\
$\cdot$ & & & \\
$\cdot$ \\
$\cdot$ \\
$\mathrm{n}$
\end{tabular}

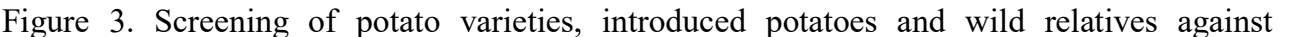

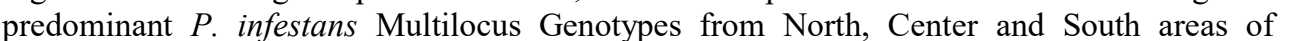
$\square[11 \mid \mathbb{ा}$

$\square$
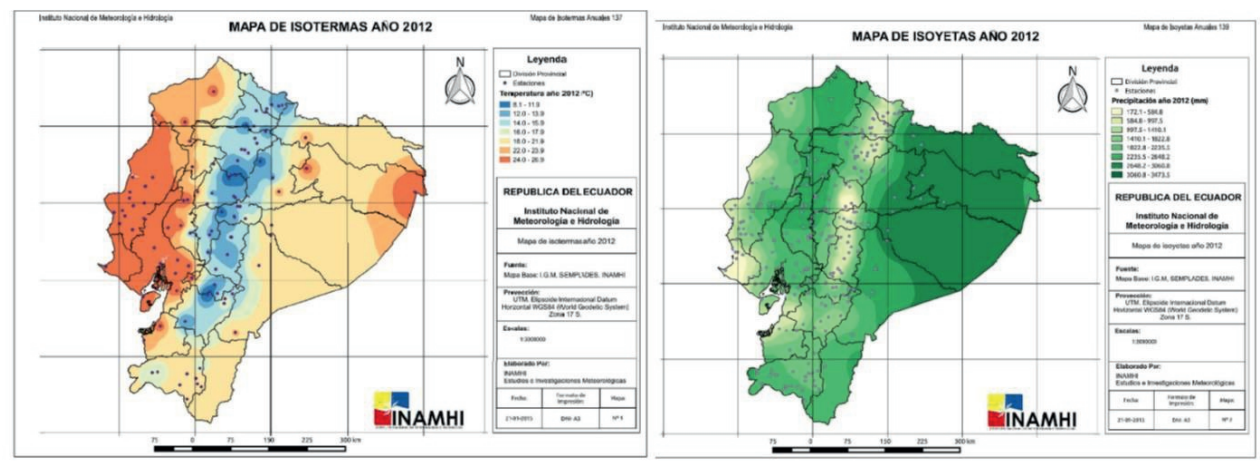

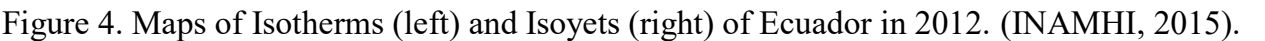




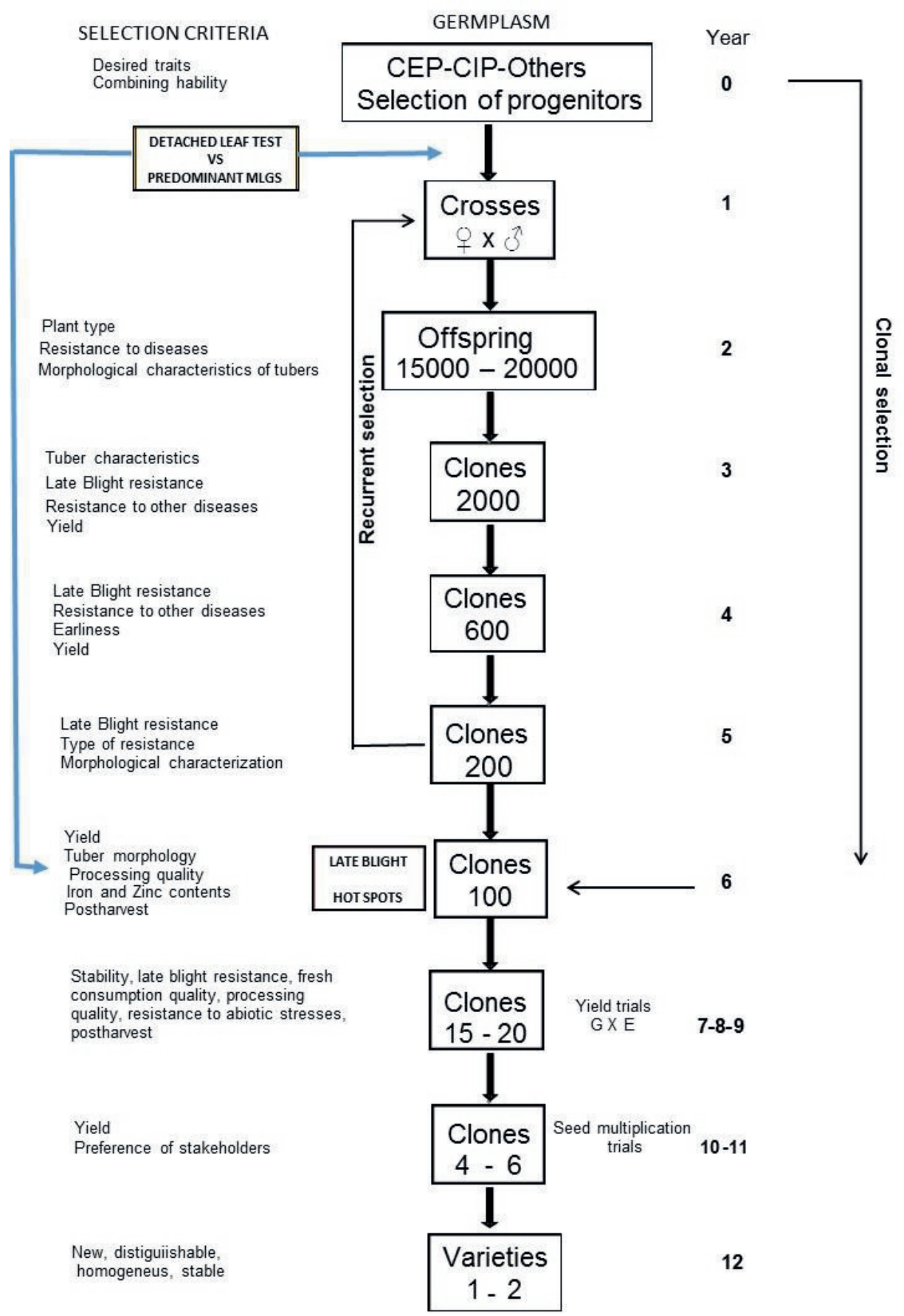




\section{Literature cited}

$\square$

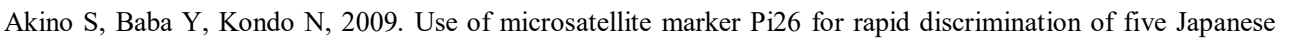

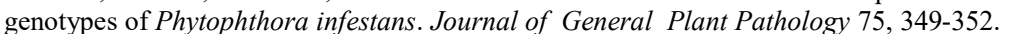

$\square$

$\square$

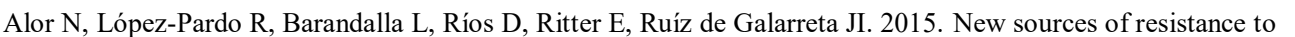

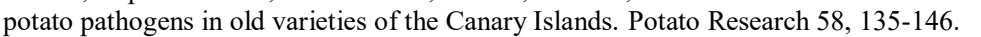

$\square$

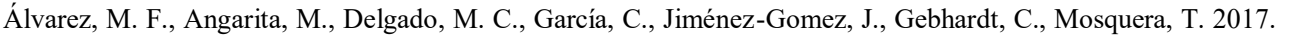
पणी

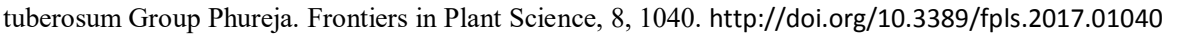
$\square$

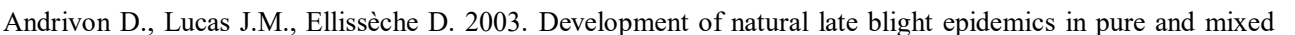

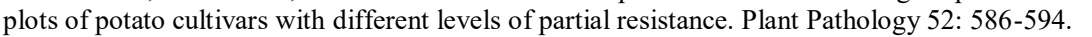
$\square$

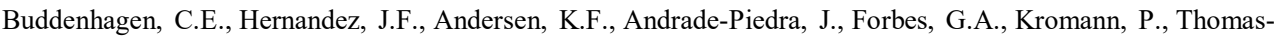

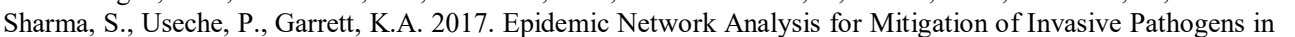

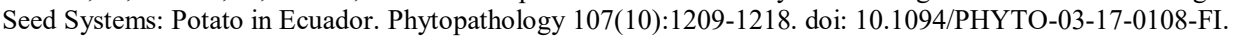
$\square$

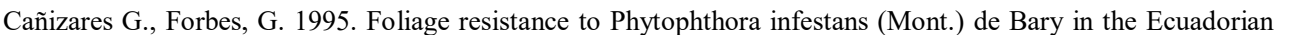

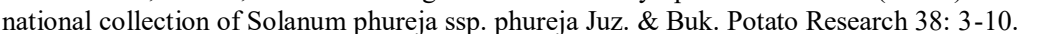
$\square$

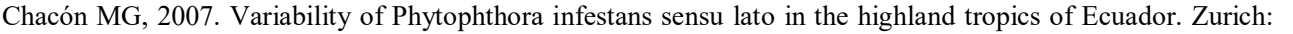

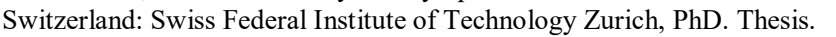

$\square$

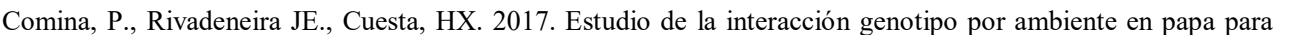

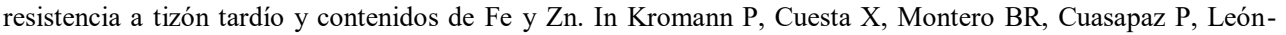

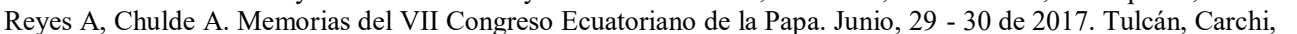

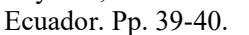

$\square$

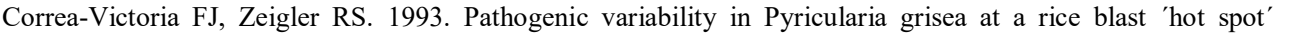

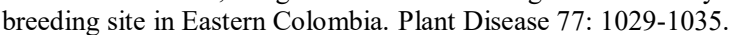
$\square$

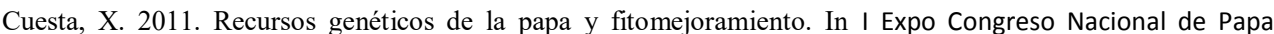

(Expopapa). 25-27 de noviembre de 2010 Ibarra, Ecuador.

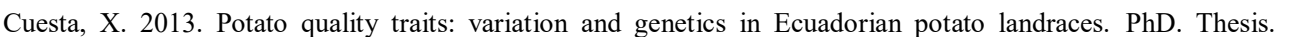

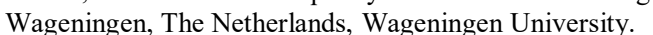

$\square$

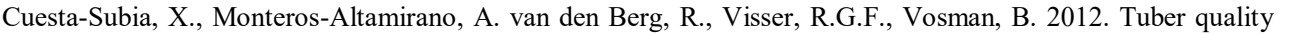

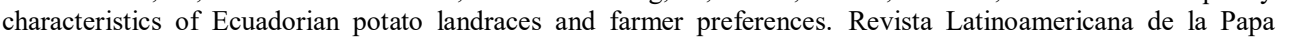
पाणाणाणाणाप

$\square$

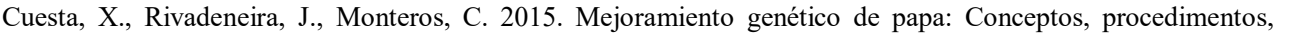

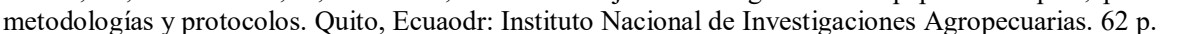
$\square$

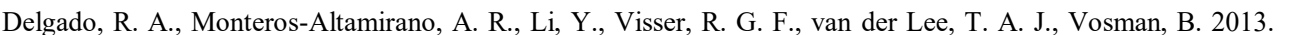

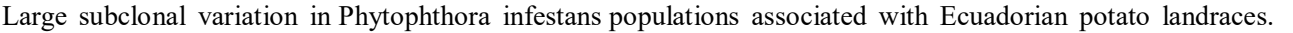

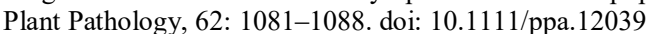

$\square$

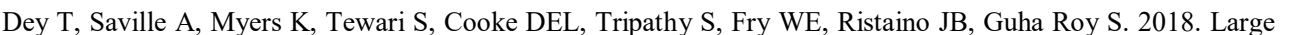

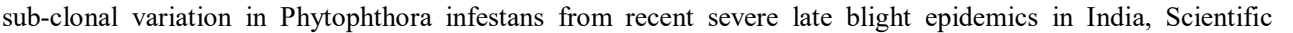

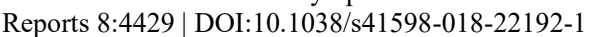

$\square$ 


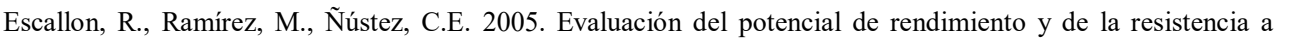

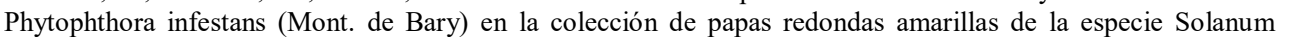

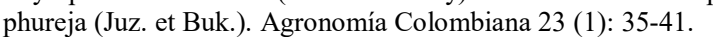

$\square$

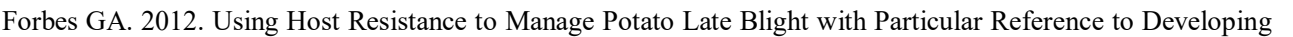

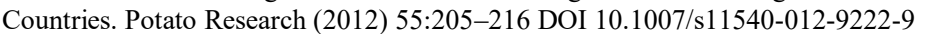

$\square \quad \square$

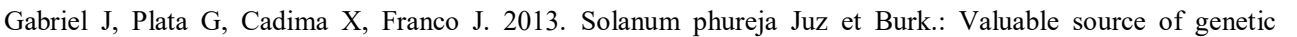

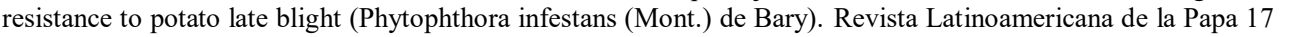
पण口ण1010ा

$\square$

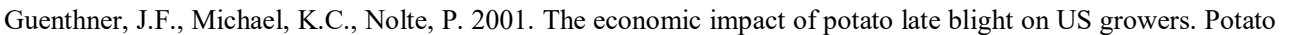

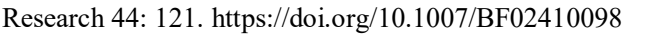

$\square \quad \square \quad \square$

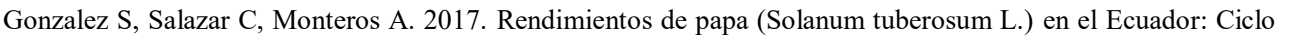

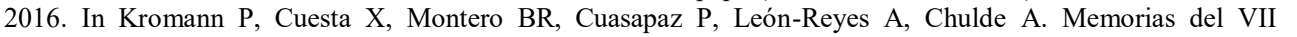

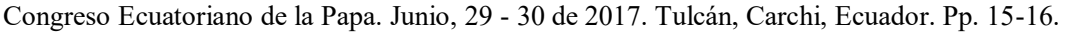
$\square$

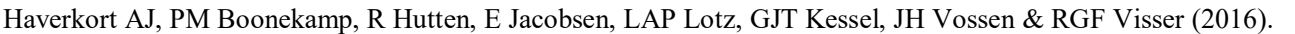

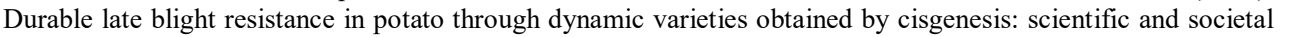

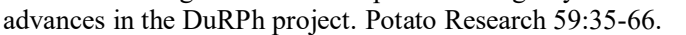

$\square$

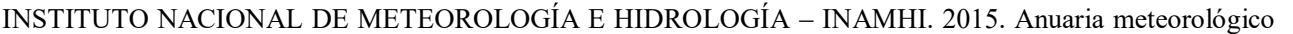

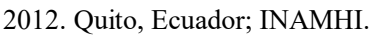

$\square$

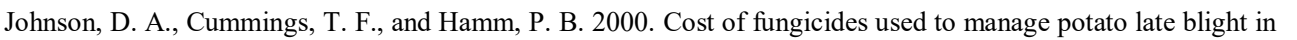

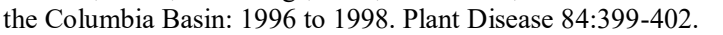
$\square$

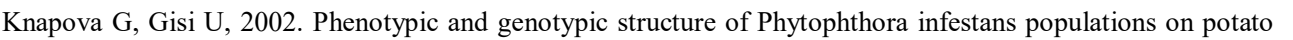

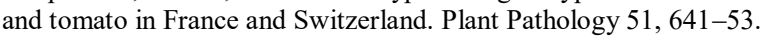

$\square$

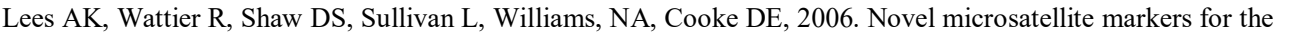

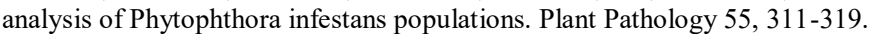
$\square$

a

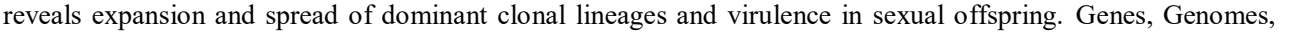

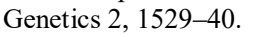

$\square$

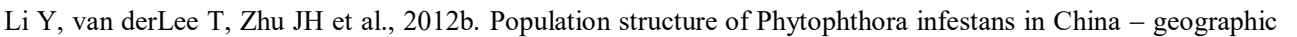

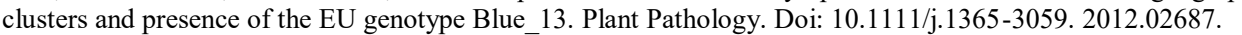
$\square$

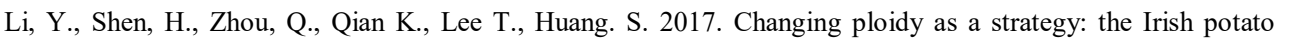

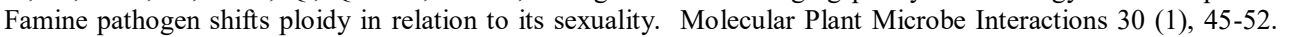

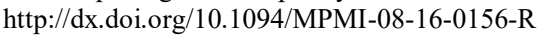

$\square$

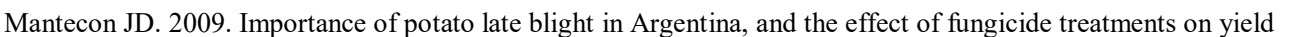

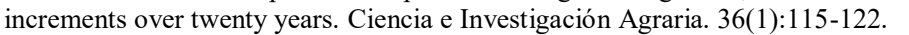

$\square$

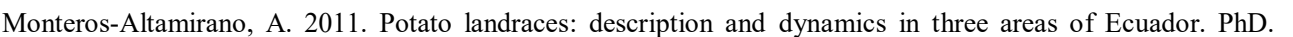

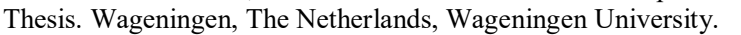

$\square$

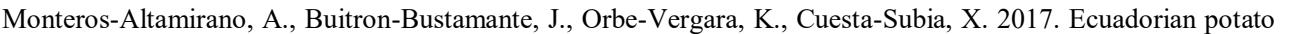

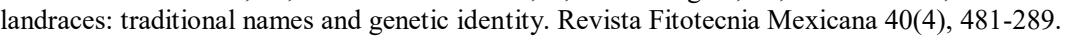
$\square$

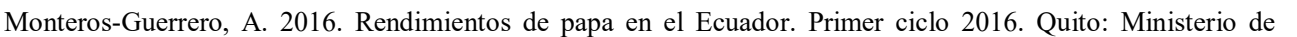

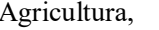
प्णाणाण
$\square$
ㅁणणㅣㅁ
$\square$

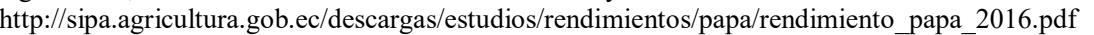

$\square$ 


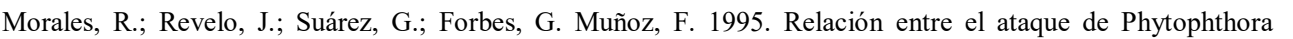

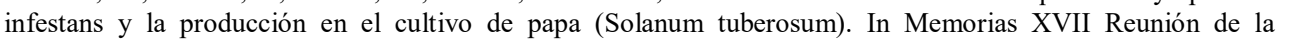

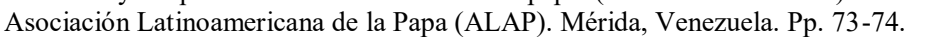
$\square$

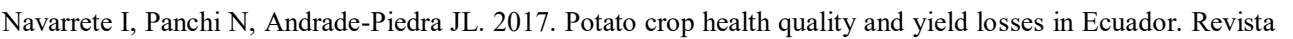

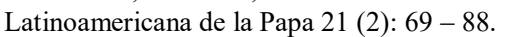

$\square$

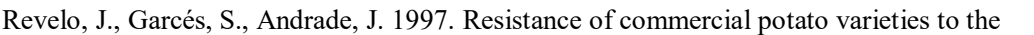

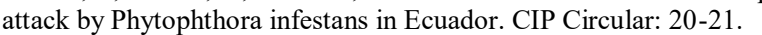
$\square$

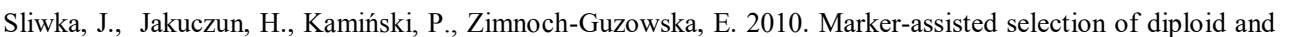

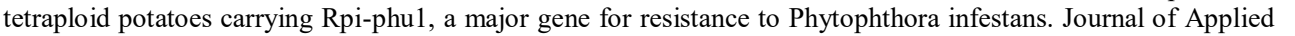

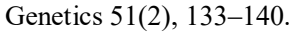

$\square$

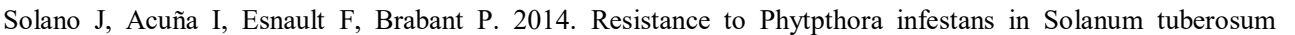

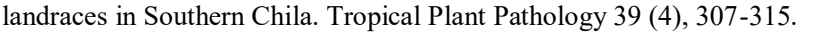

$\square$

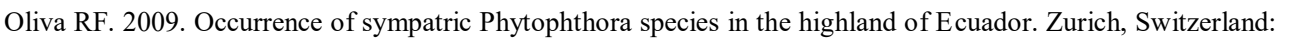

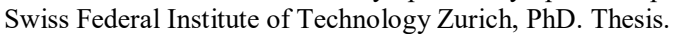

$\square$

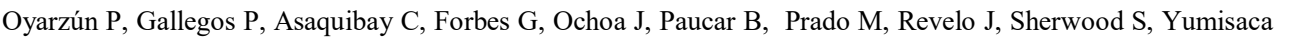

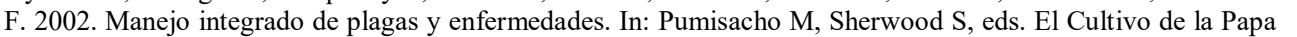

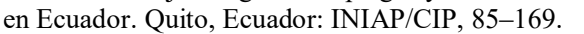

$\square$

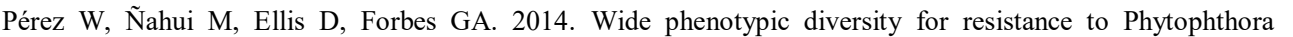

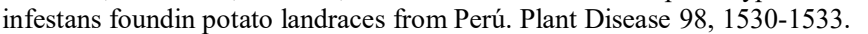
$\square$

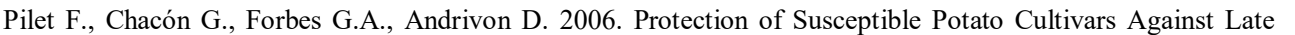

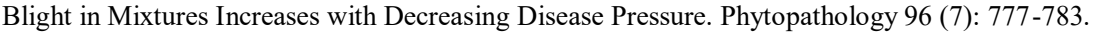
$\square$

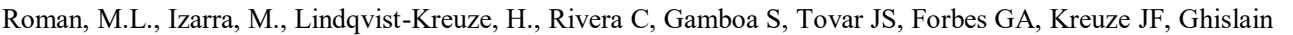

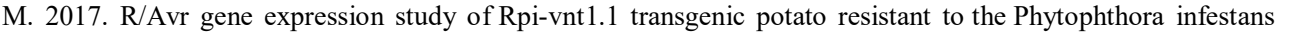

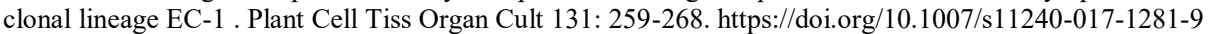
$\square$

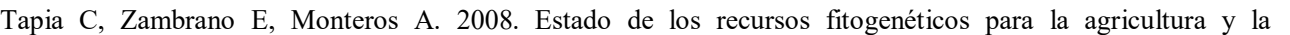

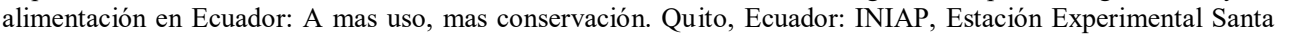

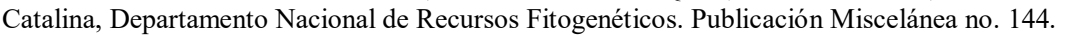

$\square \quad \square$

a

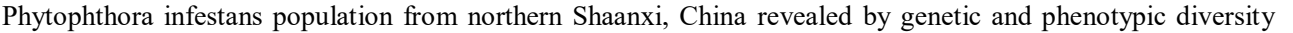

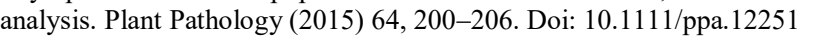
$\square$

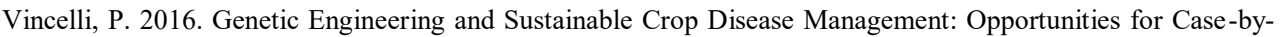

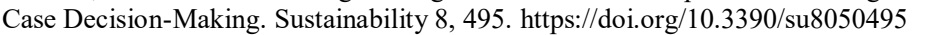

$\square$

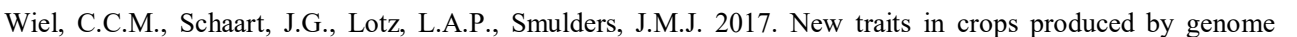

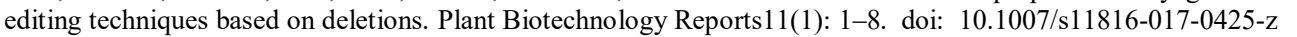
$\square$

$\square$ 


\section{Summary}

$\square$

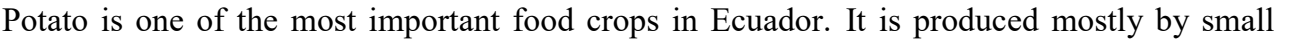

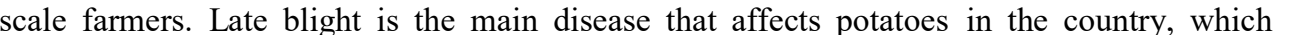

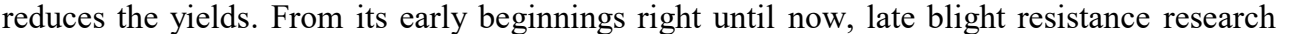

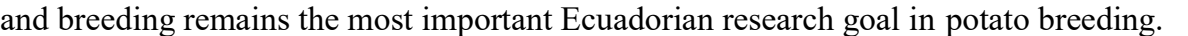

\section{$\square$}

घ)

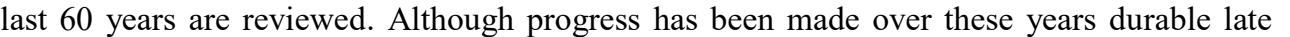

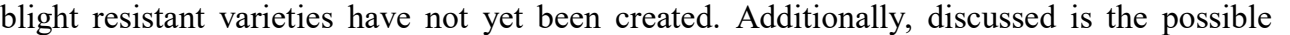

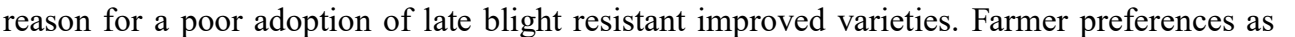

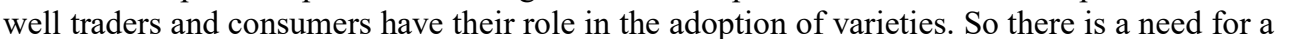

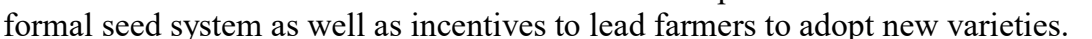

四

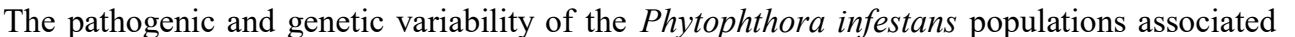

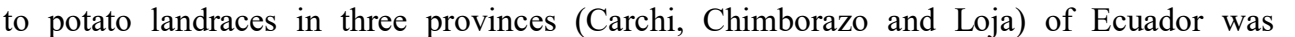

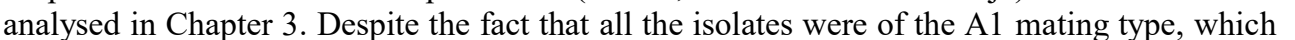

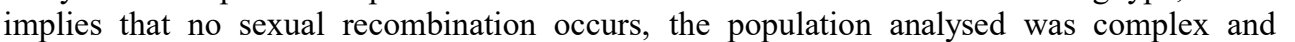

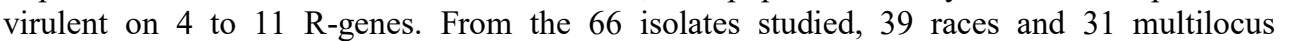

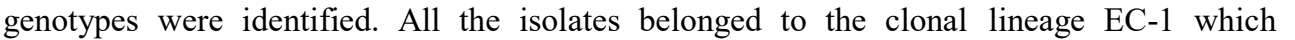

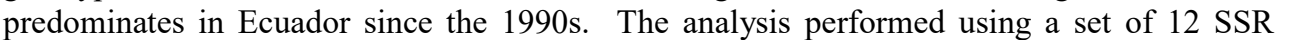

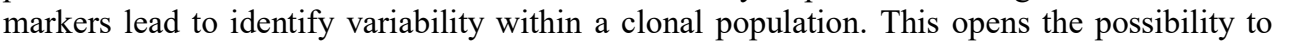

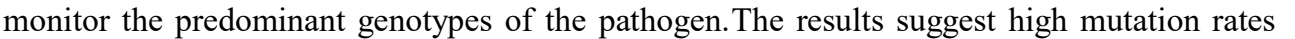

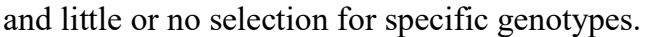

\section{$\square$}

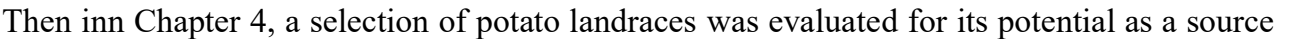

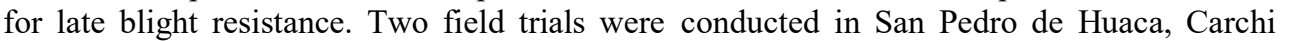

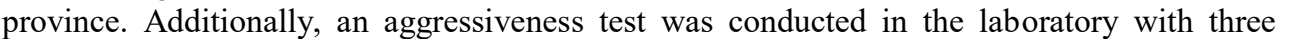

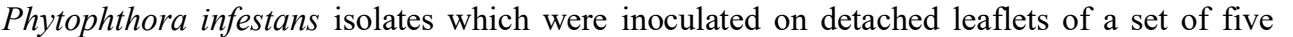

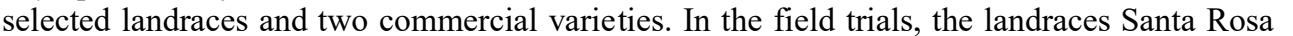

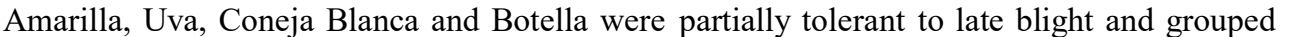

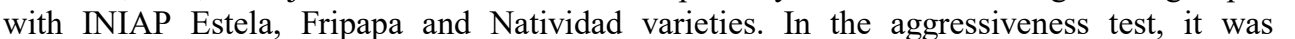

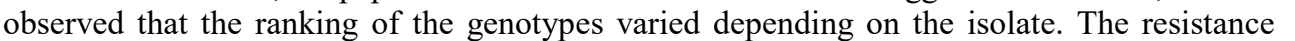

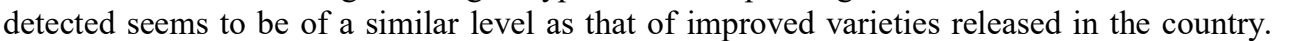

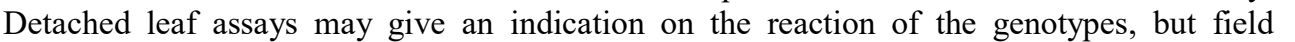

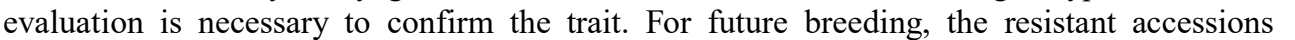

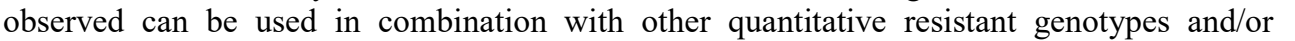

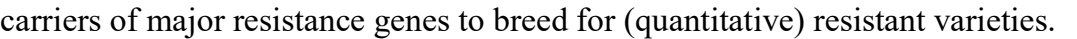
$\square$

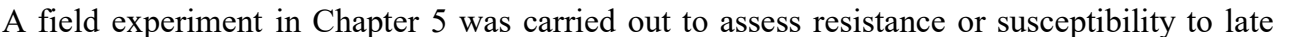

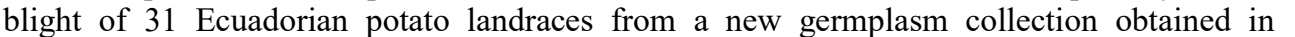

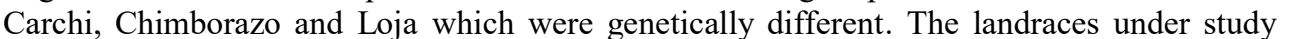

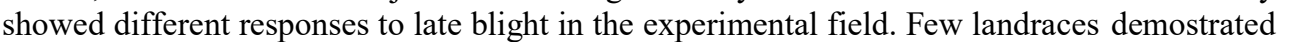

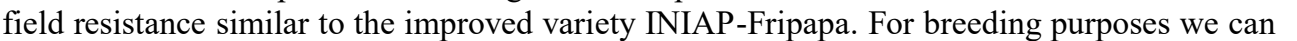

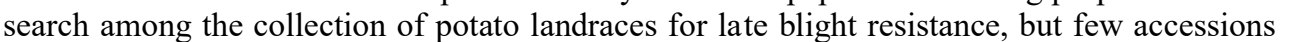

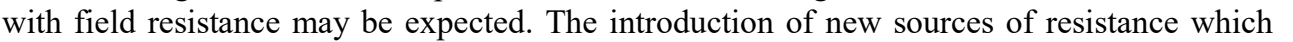




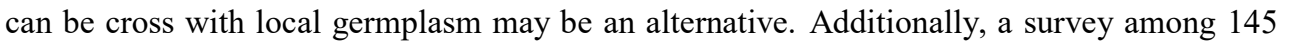

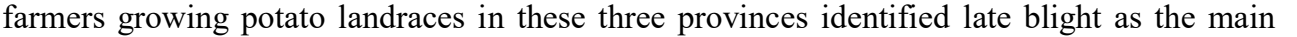

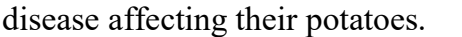

\section{$\square$}

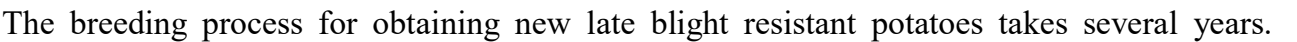

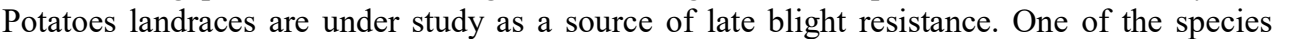

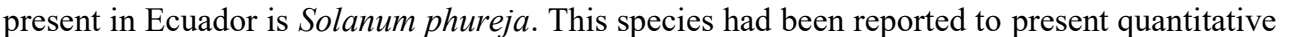

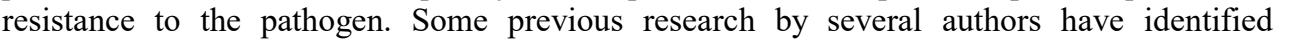

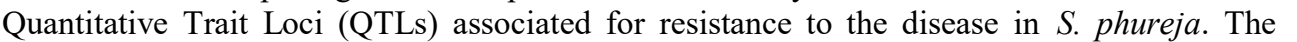

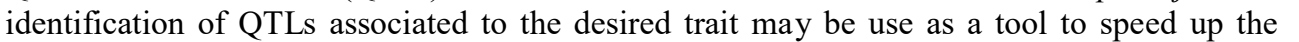

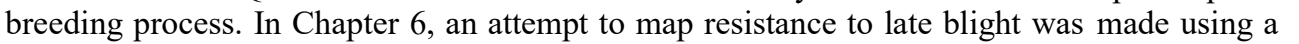

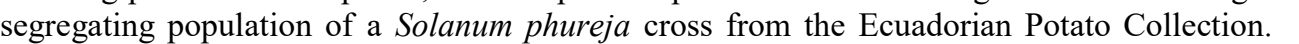

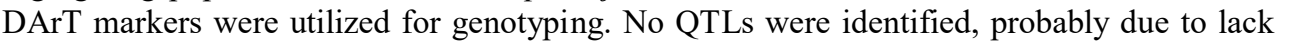

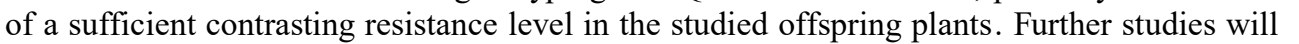

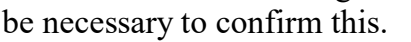

$\square$

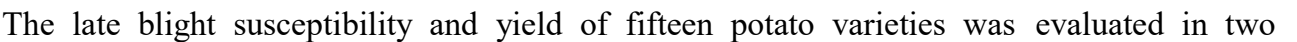

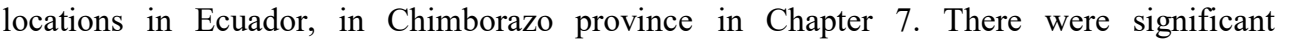

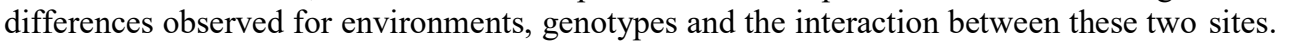

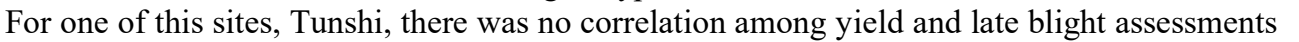

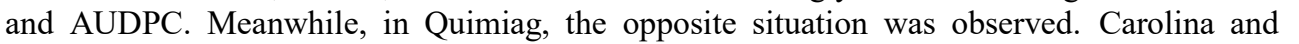

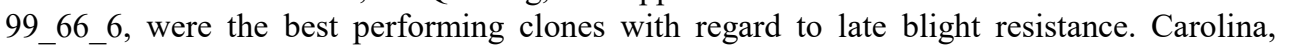

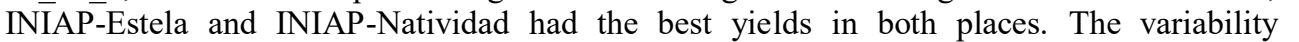

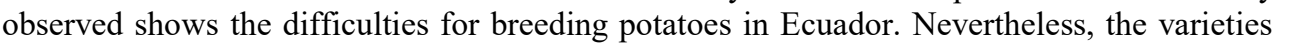

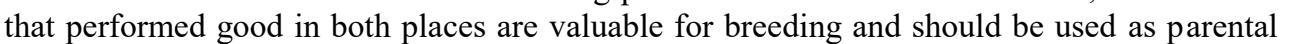

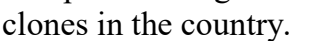

$\square$

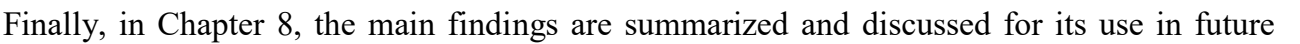

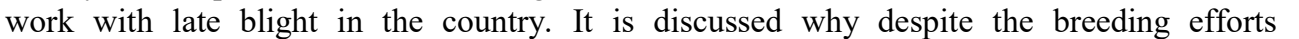

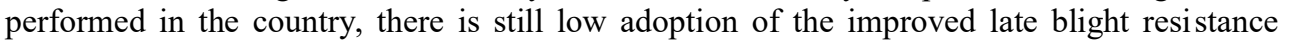

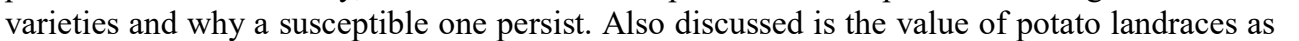

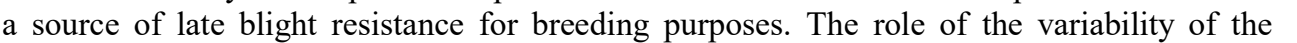

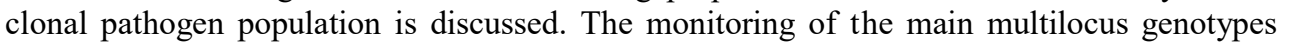

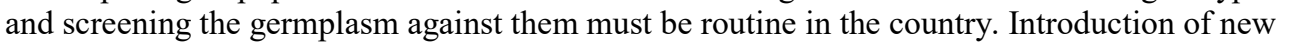

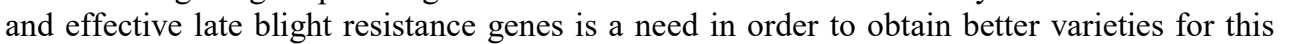

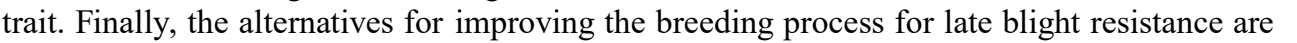

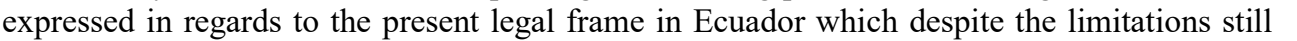

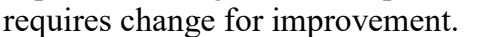

$\square$

$\square$ 


\section{Resumen $\square$}

$\square$

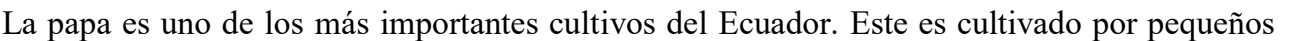

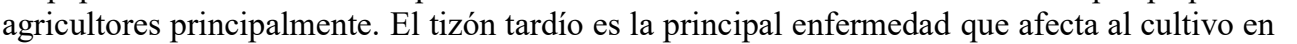

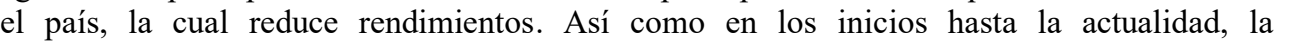

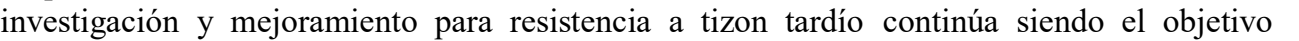

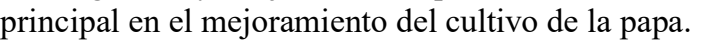

$\square$

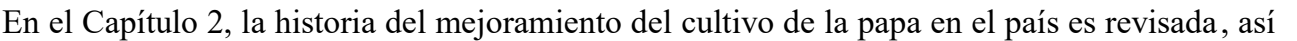

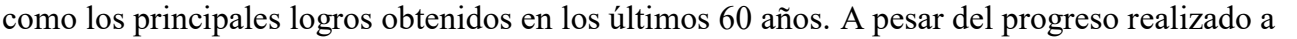
ए

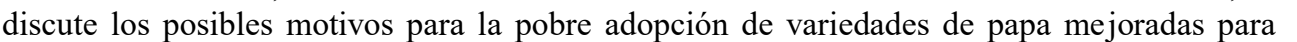

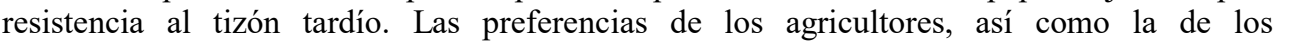

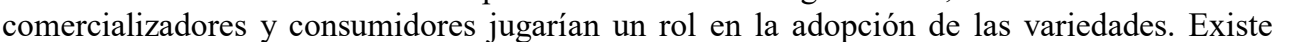

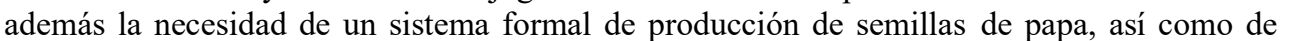

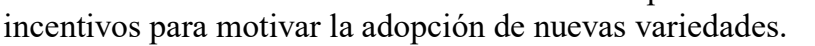

$\square$

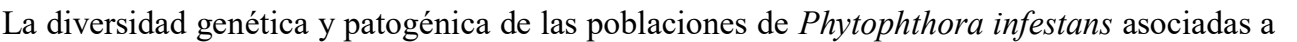

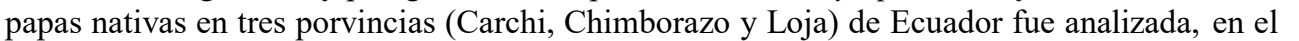

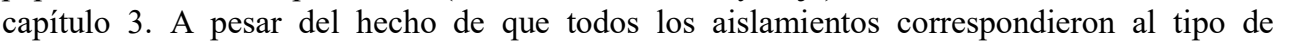

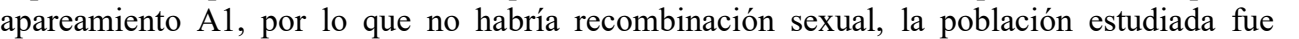

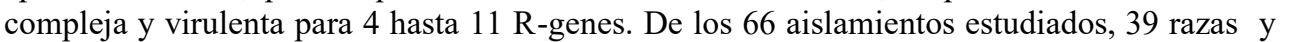

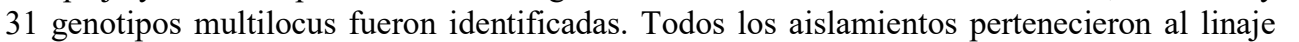

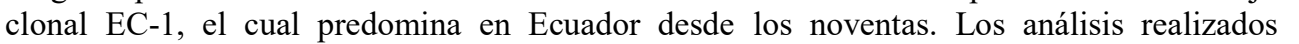

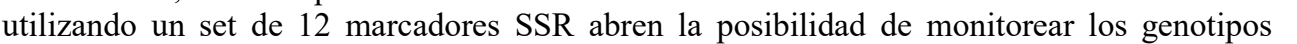

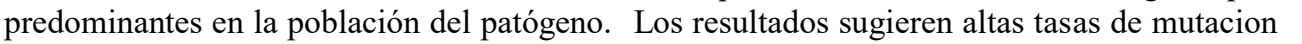

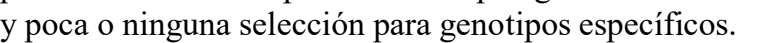

$\square$

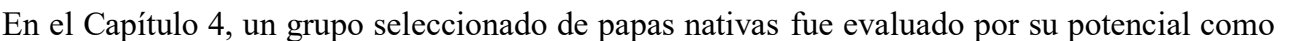

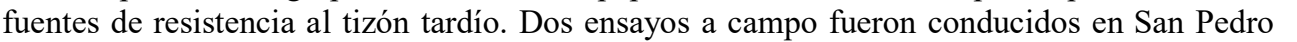

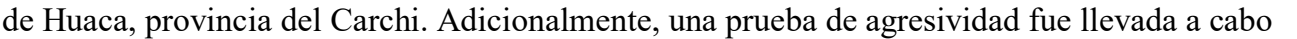

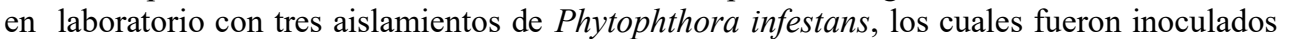

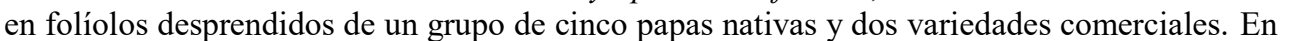

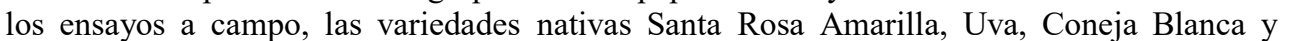

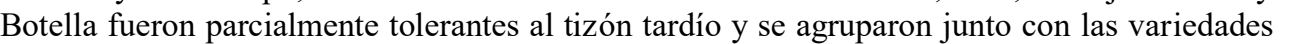

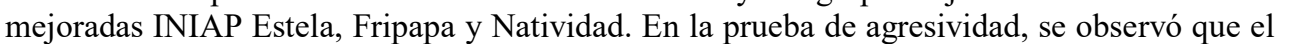

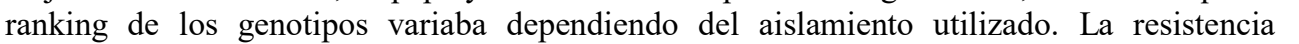

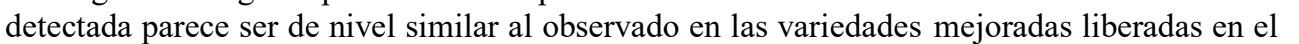

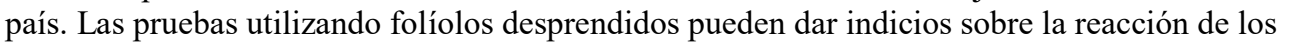

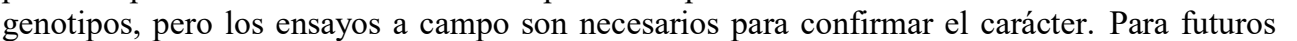

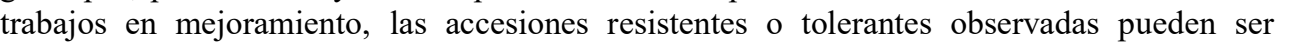

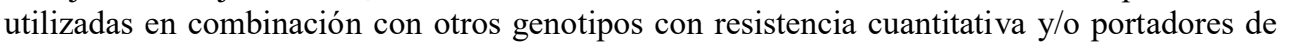

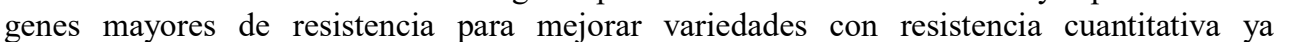

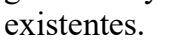

$\square$

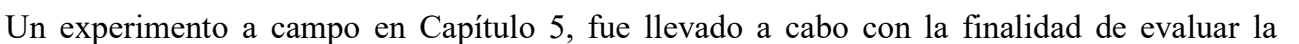

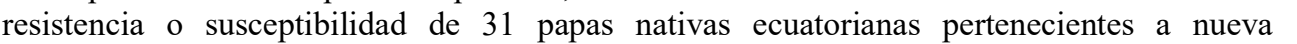

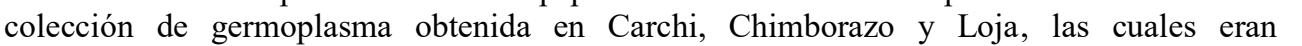

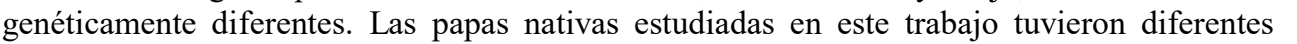




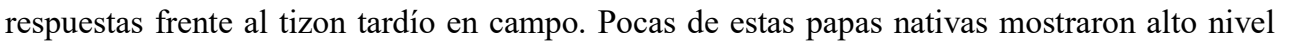

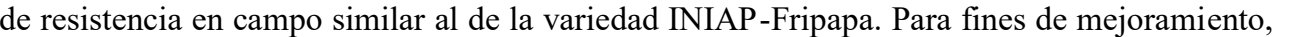

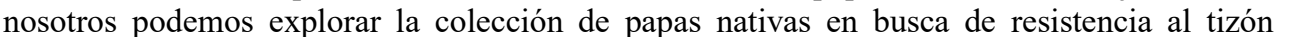

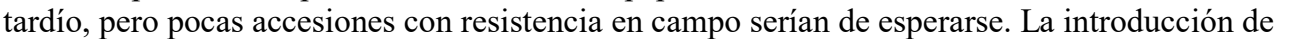

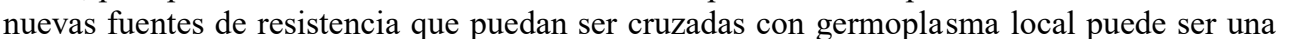

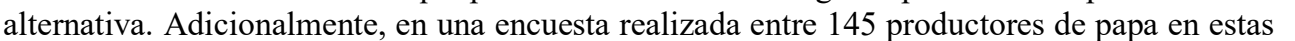

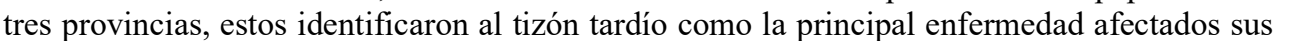

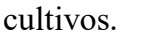

$\square$

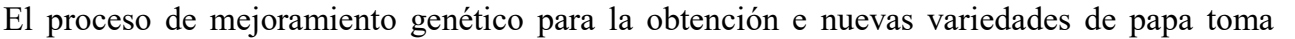

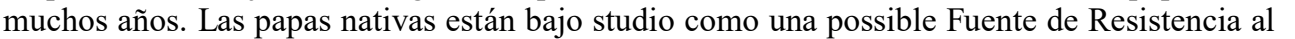

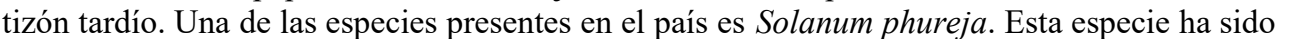

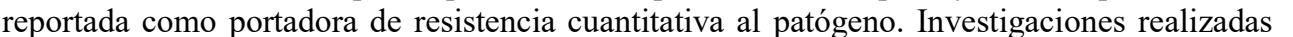

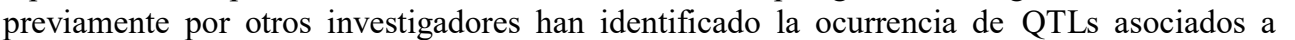

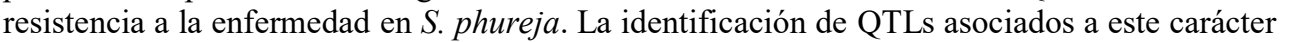

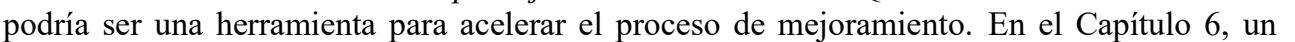

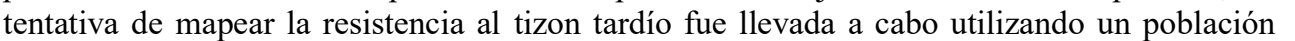

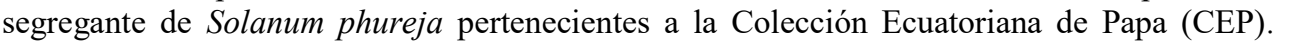

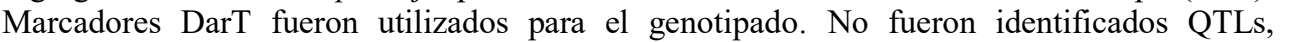

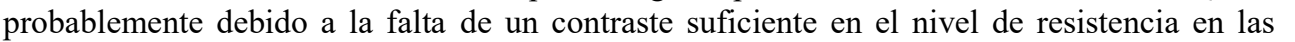

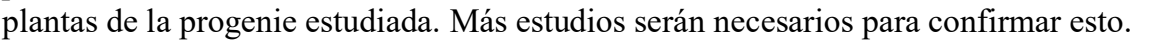
$\square$

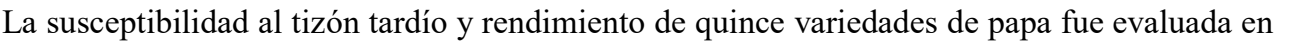

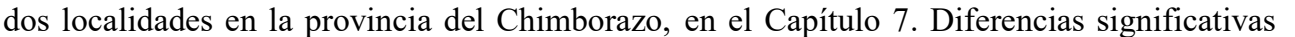

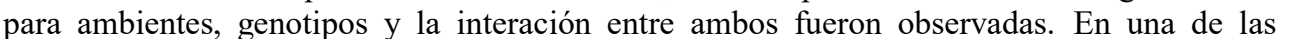

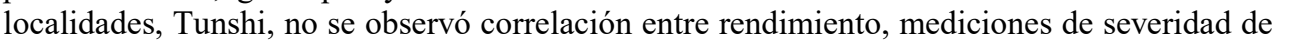

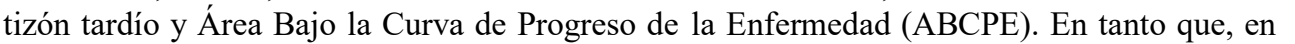

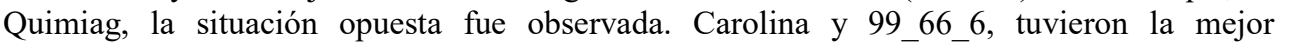

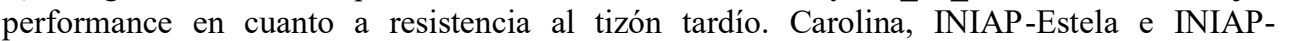

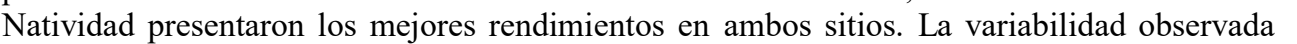

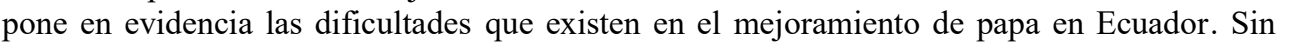

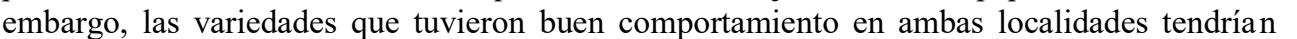

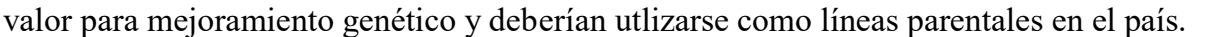
$\square$

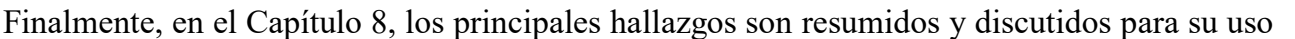

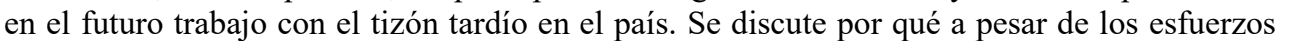

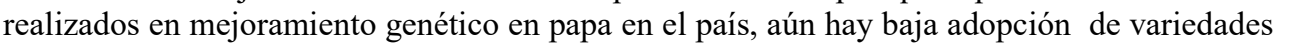

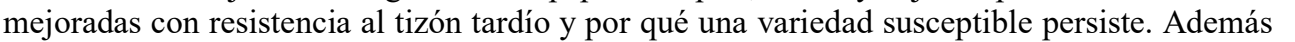

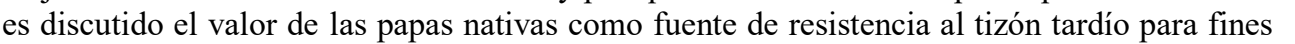

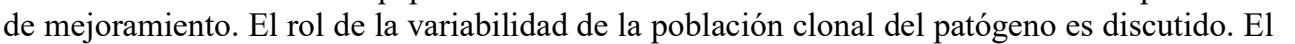

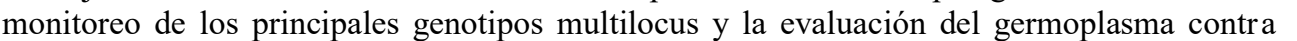

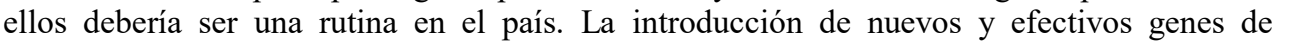

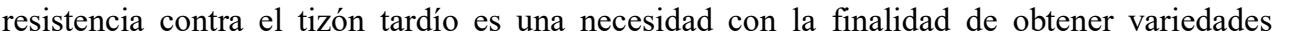

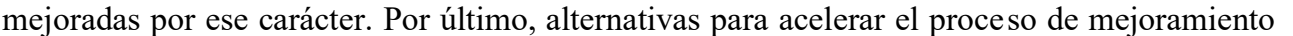

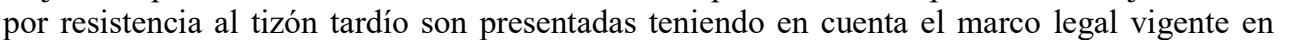

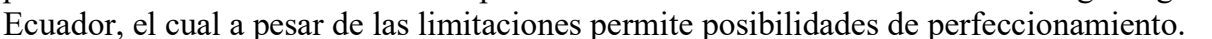
$\square$

$\square$

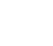




\section{Acknowledgements}

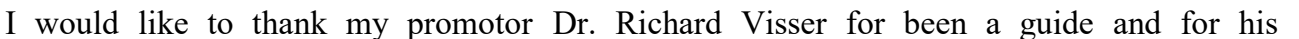

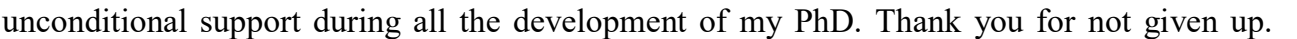

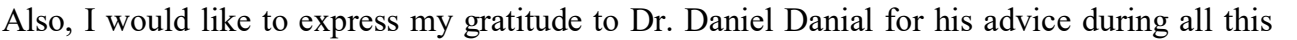

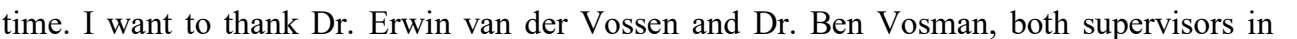

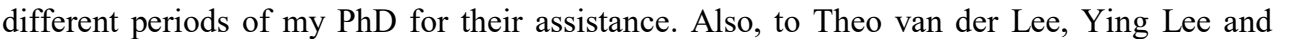

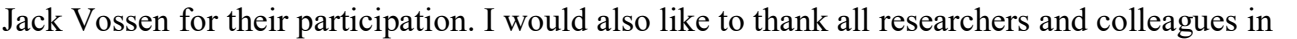

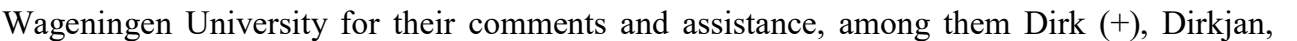

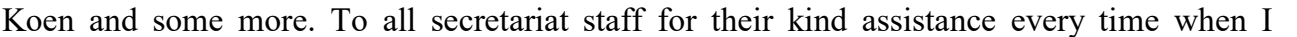

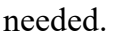

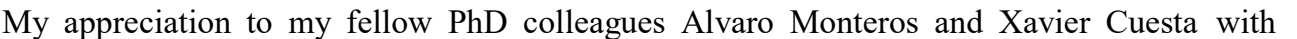

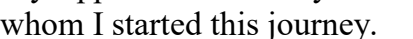

$\square$

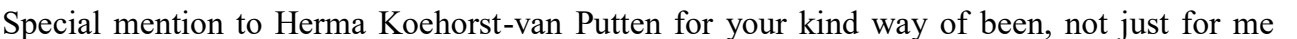

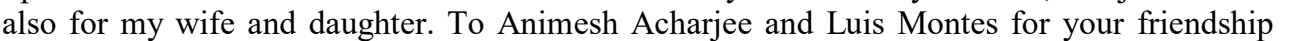

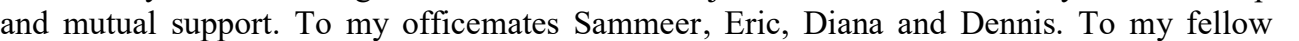

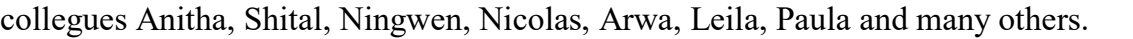

$\square$

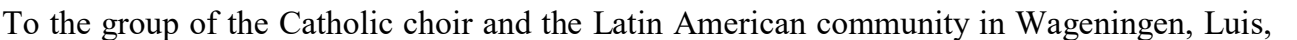

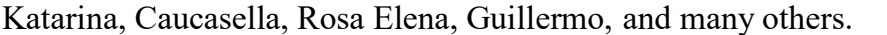

$\square$

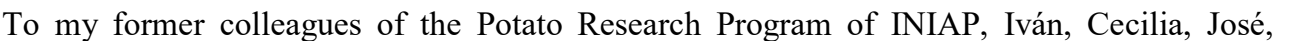

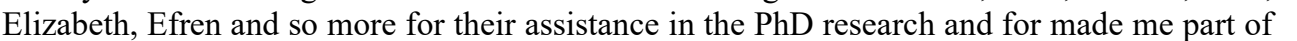
पाणाणएा

$\square$

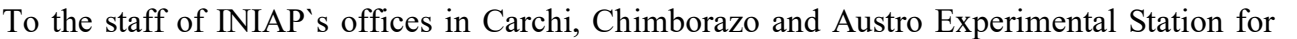

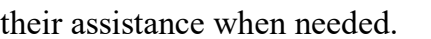

$\square$

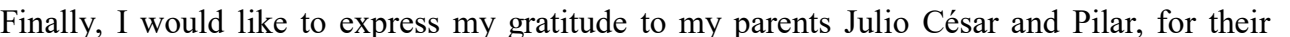

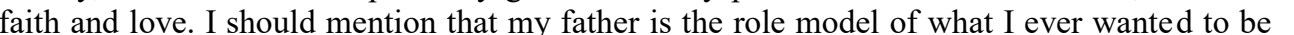

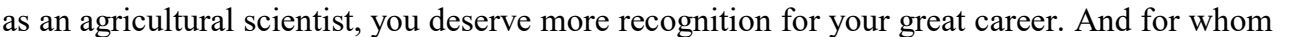

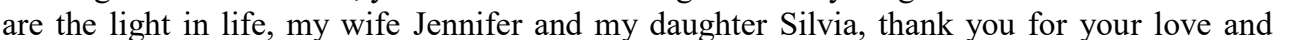

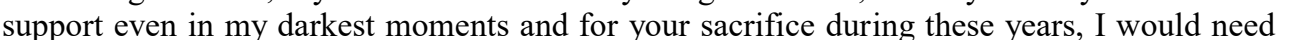

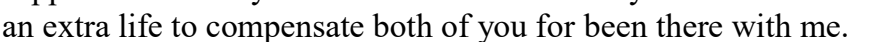

$\square$ 


\section{About the author}

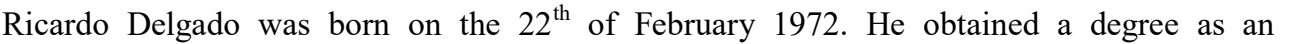

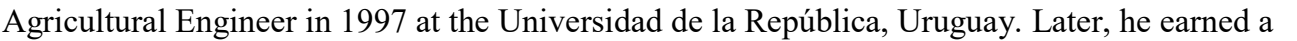

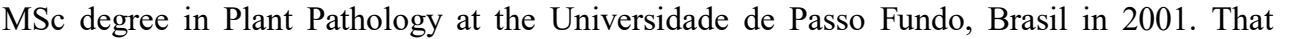

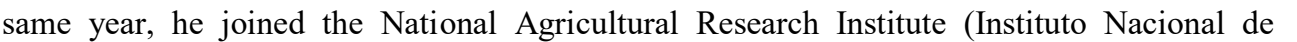

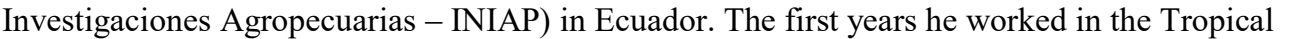
Agricultural Research Station 'Pichilingue' mainly with cocoa diseases. After that he

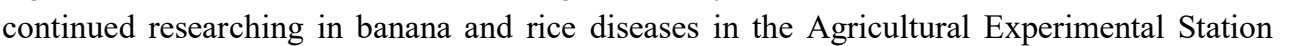
'Boliche'. Additionally, he was a Plant Pathology guest lecturer in the Escuela Superior

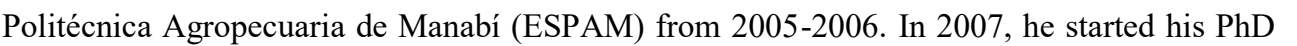

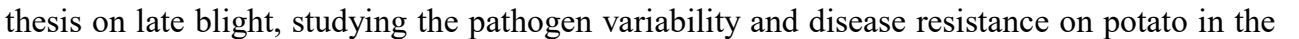

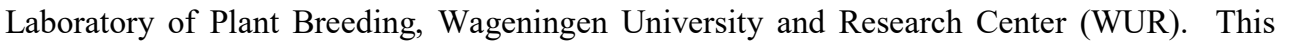

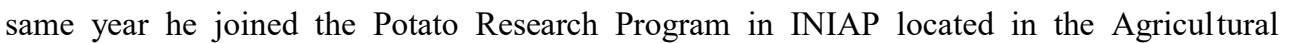

Research Station 'Santa Catalina' where he worked with late blight disease on potatoes.

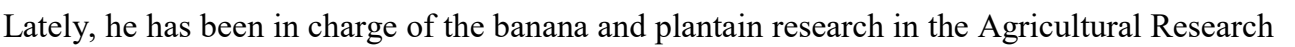

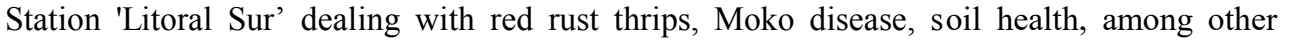

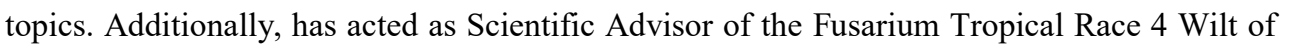

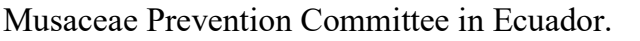




\section{List of publications}

$\square$

प

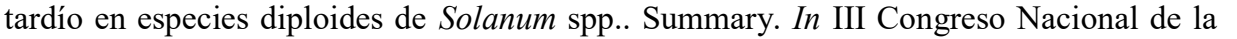

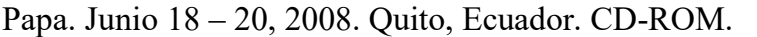

$\square$

b

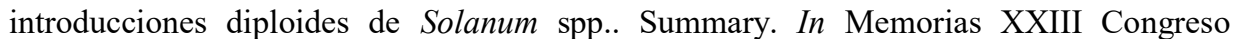

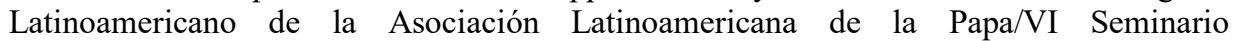

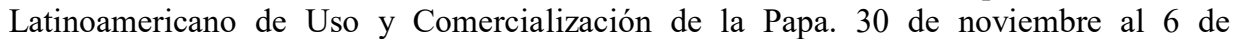

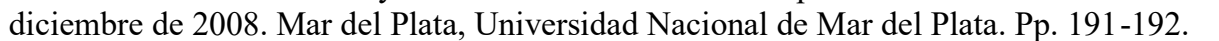

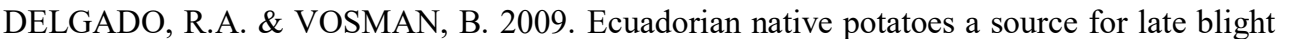

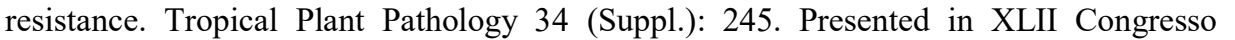

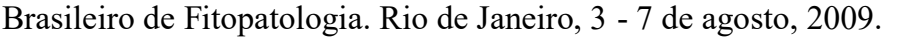

$\square$

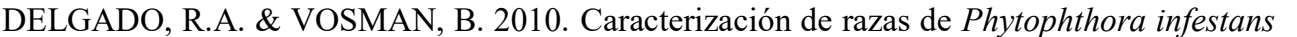

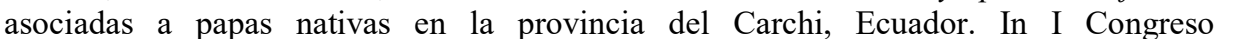

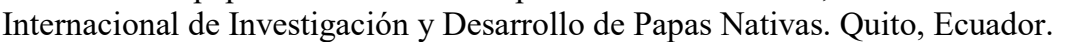

$\square \quad \square$

म

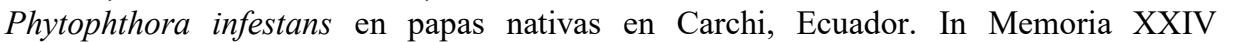

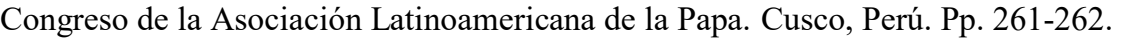

$\square$

b

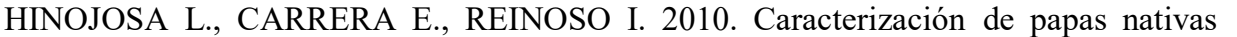

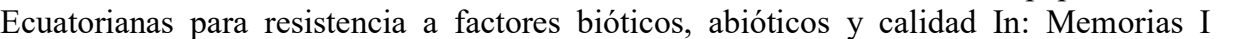

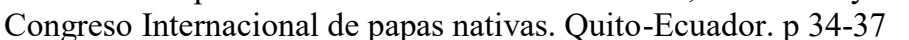

$\square$

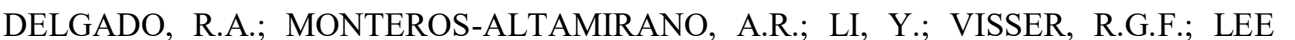

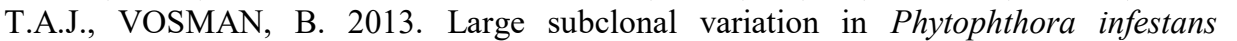

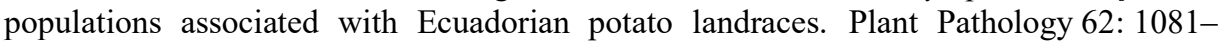

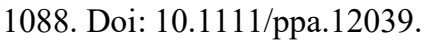

$\square$

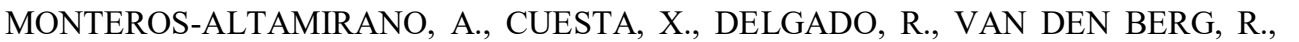

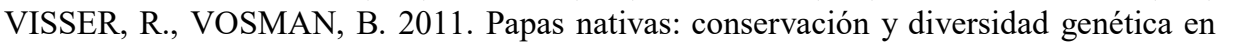

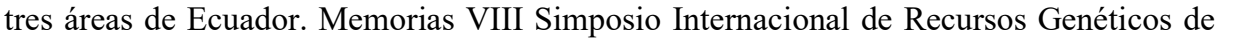

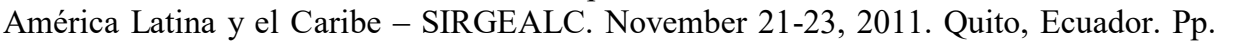
$\square|\|||| \mid$

$\square$ 


\section{Education Statement of the Graduate School}

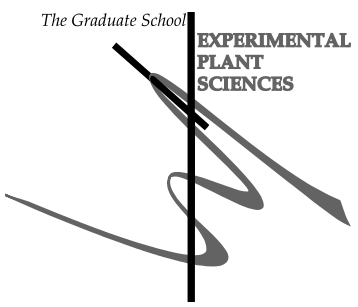

Issued to: Ricardo Delgado

Date: 21 October 2019

Group: Laboratory of Plant Breeding

University: Wageningen University \& Research

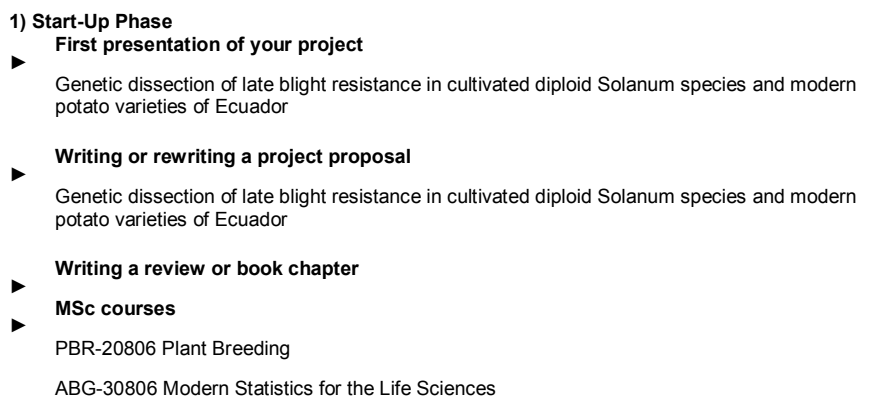

Subtotal Start-Up Phase

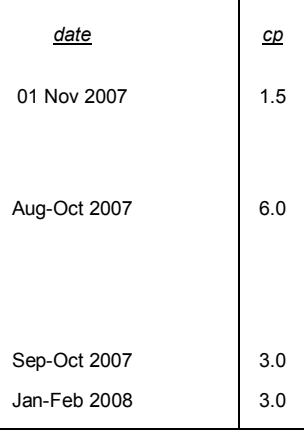

2) Scientific Exposure

EPS PhD student days

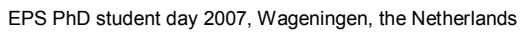

EPS theme symposia

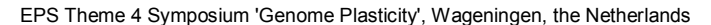

EPS Theme 2 Symposium 'Interactions between Plants and Biotic Agents' \& Willie Commelin हPS Theme 2 Symposium 'Interactions betwe

Lunteren Days and other national platforms

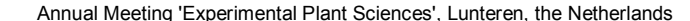

Seminars (series), workshops and symposia

European Flying Seminar: European Flying Seminar:

EPS Seminar:

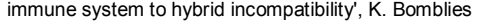

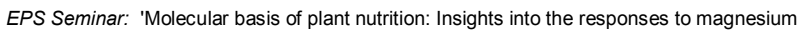

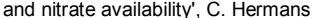

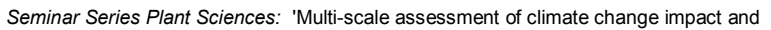

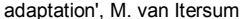

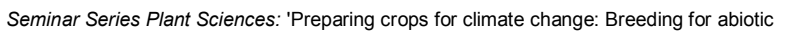

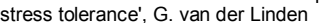

Seminar Series Plant Sciences:

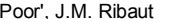

Seminar Series Plant Sciences:

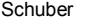

Symposium:

Seminar plus

$>$

International symposia and congresses

पाm

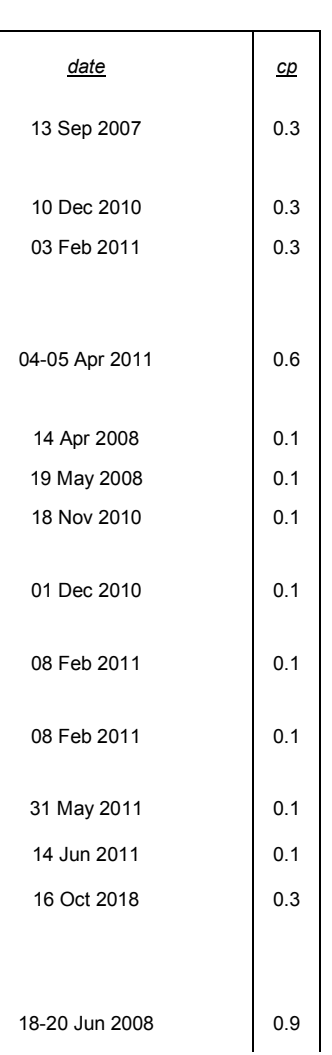




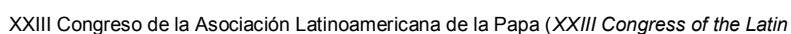
American Potato Association

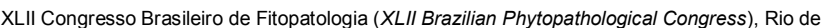
पातापालापालाए

(खण Congress on Research and Development of Native Potatoes

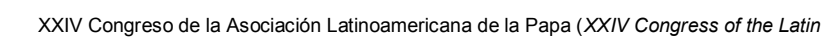

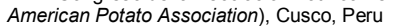

(1)

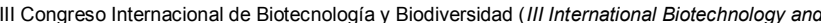
Biodiversity Congress

(II)

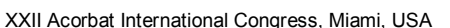

\section{Presentations}

Poster: Poster:

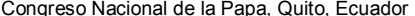

III

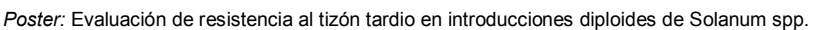
Evaluation of late blight resistance in Solanum spp. diploid accessions

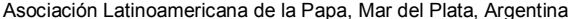

[II

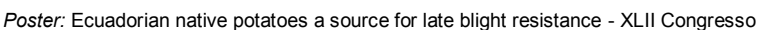

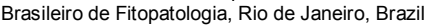

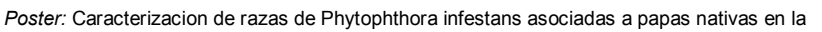

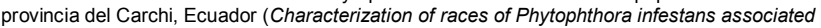
with native potatoes in Carchi province, Ecuador

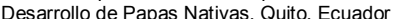

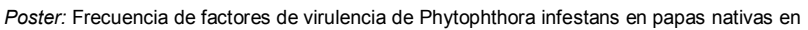

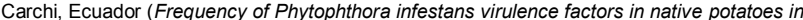
Carchi, Ecuador

II

Talk: resistance in potato cultivars

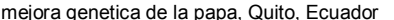

\section{IAB interview}

Excursions

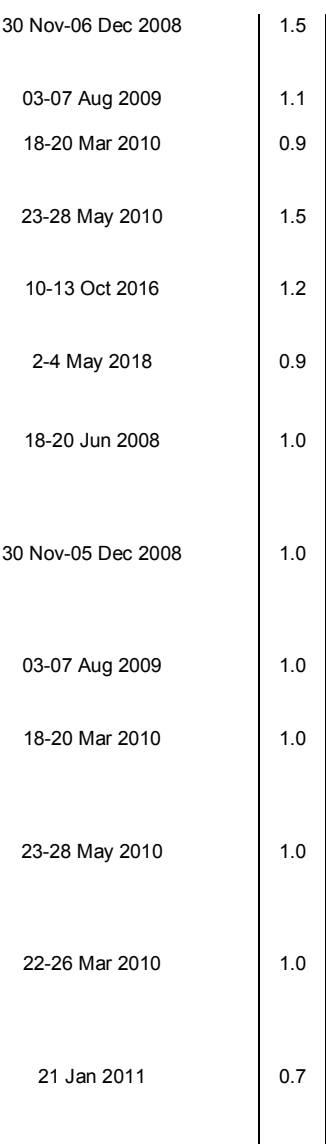

Subtotal Scientific Exposure
- $\square$ Advanced scientific courses \& workshops

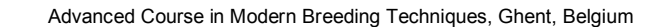

(11. analysis

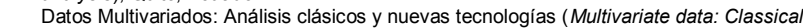
analysis and new technologies

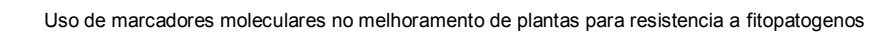
Use of molecular markers in breeding for resistance to plant pathogens

प्वापाI

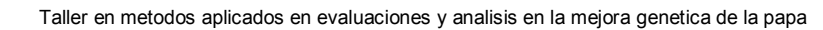
Workshop on applied methods for evaluation and analysis of genetic improvement of potatoes

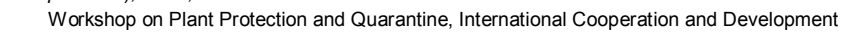

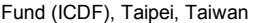

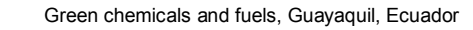

$\checkmark$ Journal club

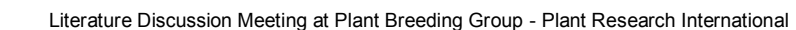

$-\square$ Individual research training

\begin{tabular}{|c|c|}
\hline 四 & 四 \\
\hline$\underline{\text { date }}$ & $\underline{c p}$ \\
\hline$\square$ & $\bar{\square}$ \\
\hline 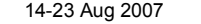 & $\square \square$ \\
\hline 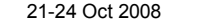 & 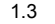 \\
\hline 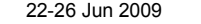 & $\square\left(\begin{array}{ll}\square \\
\end{array}\right.$ \\
\hline 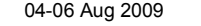 & $\square\left(\begin{array}{ll}1 \\
0\end{array}\right.$ \\
\hline 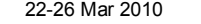 & (I) \\
\hline 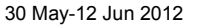 & $\square \square \square$ \\
\hline 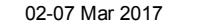 & $\square \square \square$ \\
\hline$\square$ & $\square$ \\
\hline 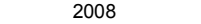 & $\square\left(\begin{array}{ll}\square \\
\end{array}\right.$ \\
\hline (1) & 四 \\
\hline
\end{tabular}

Subtotal In-Depth Studies 


\section{4) Personal Development}

$\downarrow$ General skill training courses

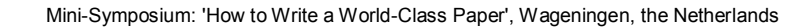

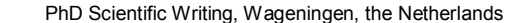

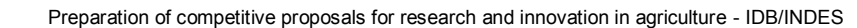

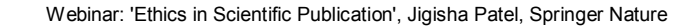

$\checkmark$ Organisation of meetings, PhD courses or outreach activities

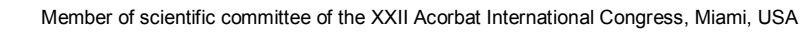

$\checkmark \square$ Membership of EPS PhD Council

Subtotal Personal Development

\begin{tabular}{|c|c|}
\hline 四 & 四 \\
\hline$\underline{\text { date }}$ & $\underline{c p}$ \\
\hline$\square$ & $\square$ \\
\hline 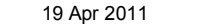 & 마마 \\
\hline 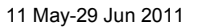 & 마맘 \\
\hline 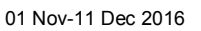 & पराप्त \\
\hline 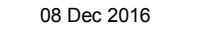 & प्वाप्र \\
\hline$\square$ & $\square$ \\
\hline 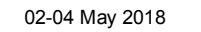 & पापा \\
\hline$\square$ & $\square$ \\
\hline
\end{tabular}

(11)

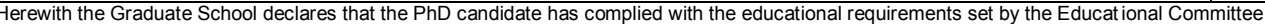

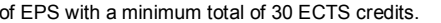


$\square$

$\square$

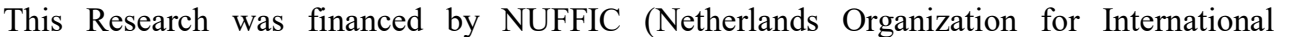

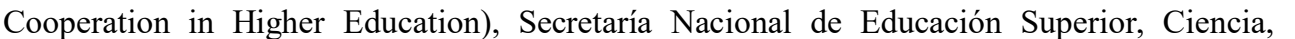

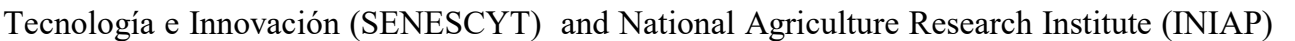

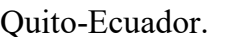

$\square$

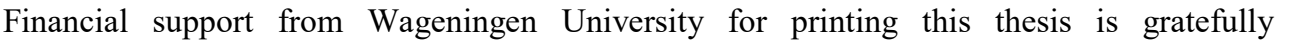
एापापापा

\section{$\square$}

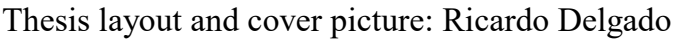

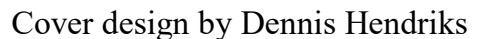

$\square$

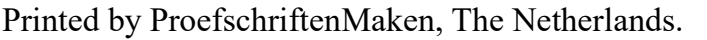


